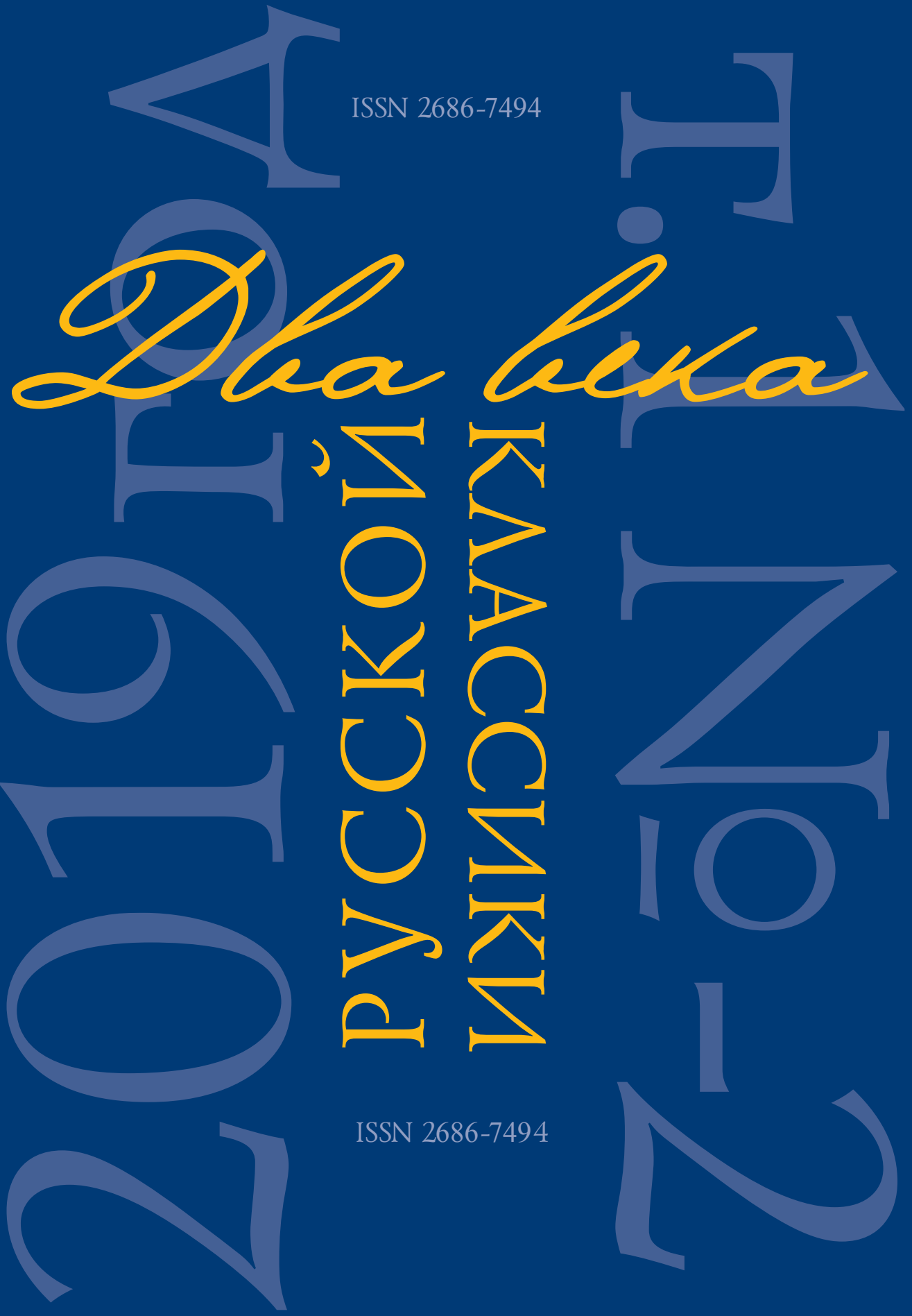


ISSN 2686-7494

Два века Two centuries

русской классики of the Russian classics

[Dva veka russkoi klassiki]

Научный журнал Academic Journal

Выходит с 2019 года Is published since 2019

2019 Том 1 № $2 \quad 2019$ Volume 1 No. 2

Учредитель и издатель: Founder and publisher:

Институт A. M. Gorky

мировой литературы Institute

им. А.М. Горького of World Literature

Российской of the Russian

академии наук Academy of Science

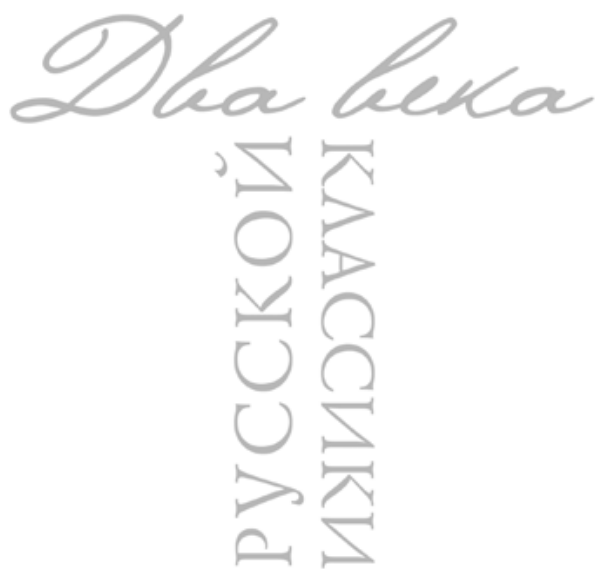




\section{Редакционная коллегия журнала «Два века русской классики»}



\section{Главный редактор}

Щербакова Марина Ивановна (Институт мировой литературы им. А. М. Горького Российской академии наук, г. Москва)

Заместитель главного редактора

Виноградов Игорь Алексеевич (Институт мировой литературы им. А. М. Горького Российской академии наук, г. Москва)

Ответственный секретарь

Андреева Валерия Геннадьевна (Институт мировой литературы им. А. М. Горького Российской академии наук, г. Москва)

\section{Редакционная коллегия}

Гулин Александр Вадимович (Институт мировой литературы им. А. М. Горького Российской академии наук, г. Москва), Гуминский Виктор Мирославович (Институт мировой литературы им. А. М. Горького Российской академии наук, г. Москва), Ивинский Александр Дмитриевич (Институт мировой литературы им. А. М. Горького Российской академии наук, г. Москва), Троицкий Всеволод Юрьевич Институт мировой литературы им. А. М. Горького

Российской академии наук, г. Москва), Воропаев Владимир Алексеевич (Московский государственный университет им. М. В. Ломоносова, г. Москва), Генералова Наталья Петровна (Институт русской литературы (Пушкинский Дом) Российской Академии наук, г. Санкт-Петербург), Захаров Владимир Николаевич (Петрозаводский государственный университет, г. Петрозаводск, Российский фонд фундаментальных исследований,

г. Москва), Коровин Владимир Леонидович (Московский государственный университет им.

М. В. Ломоносова, г. Москва), Лебедев Юрий Владимирович (Костромской государственный университет, г. Кострома), Михайлова Наталья Ивановна

(Государственный музей А. С. Пушкина, г. Москва), Мосалева Галина Владимировна (Удмуртский государственный университет, г. Ижевск), Николаева Евгения Васильевна

(Московский педагогический государственный университет, г. Москва), Николаева Светлана Юрьевна (Тверской государственный университет, г. Тверь), Федоров Алексей Владимирович (издательство «Русское слово», г. Москва), Чернышева Елена Геннадьевна Московский педагогический государственный университет, г. Москва)

\section{Иностранные члены редакционной коллегии}

Авидзба Василий Шамониевич (научно-исследовательский центр «Абхазская энциклопедия», г. Сухум, Абхазия), Амберг Лоренцо (дипломат и посол Швейцарии, г. Женева, Швейцария), Боханд Мохаммад Латиф (посол Афганистана в России, г. Кабул, Афганистан), Гини Джузеппе (Университет им. Карло Бо, г. Урбино, Италия), Донсков Андрей Александрович (Славянская исследовательская группа при университете Оттавы, г. Оттава, Канада), Кавацца Антонелла (Университет им. Карло Бо, г. Урбино, Италия), Луцевич Людмила Федоровна (Варшавский университет, г. Варшава, Польша), Михед Павел Владимирович (Институт литературы им. Т. Шевченко Национальной академии наук Украины, г. Киев, Украина), Олджай Тюркан (Стамбульский университет, г. Стамбул, Турция), Пиотровска Иоанна (Варшавский университет, г. Варшава, Польша), Саверченко

Иван Васильевич («Институт литературоведения им. Янки Купалы» Национальной академии Наук Беларуси, г. Минск, Беларусь), Терзич Славенко (посол Сербии, г. Белград, Сербия) 


\section{The editorial board of the journal «Two centuries of the Russian classics»}



Editor-in-Chief

Scherbakova Marina Ivanovna (A. M. Gorky Institute of World Literature the Russian Academy of Sciences, Moscow)

Deputy Editor-in-Chief

Vinogradov Igor Alekseevich (A. M. Gorky Institute of World Literature the Russian Academy of Sciences, Moscow)

Managing Editor

Andreeva Valeria Gennadyevna (A. M. Gorky Institute of World Literature the Russian Academy of Sciences, Moscow)

\section{Editorial board}

Gulin Alexander Vadimovich (A. M. Gorky Institute of World Literature the Russian Academy of Sciences, Moscow), Guminsky Victor Miroslavovich (A. M. Gorky Institute of World Literature the Russian Academy of Sciences, Moscow), Ivinsky Alexander Dmitrievich (A. M. Gorky Institute of World Literature the Russian Academy of Sciences, Moscow), Troitsky Vsevolod Yuryevich (A. M. Gorky Institute of World Literature the Russian Academy of Sciences, Moscow), Voropayev Vladimir Alekseyevich (Lomonosov Moscow State University, Moscow), Generalova Natalya Petrovna (Institute of Russian Literature (Pushkinskiy Dom) of the Russian Academy of Sciences, St. Petersburg), Zakharov Vladimir Nikolaevich (Petrozavodsk state university, Petrozavodsk, Russian Federal Property Fund, Moscow), Korovin Vladimir Leonidovich (Lomonosov Moscow State University, Moscow), Lebedev Yuriy Vladimirovich (Kostroma State University, Kostroma), Mikhaylova Natalya Ivanovna (State Museum of A. S. Pushkin, Moscow), Mosaleva Galina Vladimirovna (Udmurt State University, Izhevsk), Nikolaeva Evgenia Vasilyevna (Moscow Pedagogical State University, Moscow), Nikolaeva Svetlana Yurevna (Tver State University, Tver), Fedorov Alexey Vladimirovich (Russian Word publishing house, Moscow), Chernysheva Elena Gennadyevna (Moscow Pedagogical State University, Moscow)

\section{Foreign members of the editorial board}

Avidzba Vasily Shamoniyevich (Abkhazian Encyclopedia research center, Sukhum, Abkhazia), Amberg Lorenzo (Diplomat and ambassador of Switzerland, Geneva, Switzerland), Bokhand Mohammad Latif (Ambassador of Afghanistan in Russia, Kabul, Afghanistan), Genya Giuseppe (University of Carlo Bo, Urbino, Italy), Donskov Andrey Aleksandrovich (Slavic research group at the university of Ottawa, Ottawa, Canada), Kavazza Antonella (University of Carlo Bo, Urbino, Italy), Lutsevich Lyudmila Fiodorovna (Warsaw university, Warsaw, Poland), Mikhed Pavel Vladimirovich (Institute of literature of T. Shevchenko of National Academy of Sciences of Ukraine, Kiev, Ukraine), Oldzhay Tyurkan (Istanbul university, Istanbul, Turkey), Piotrovsk Ioann (Warsaw university, Warsaw, Poland), Saverchenko Ivan Vasilyevich ("Institute of Literary Criticism of Janka Kupala" of National Academy of Sciences of Belarus, Minsk, Belarus), Terzich of Slavenko (Ambassador of Serbia, Belgrade, Serbia) 


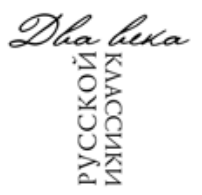

\section{Содержание}

6 Памяти П. В. Палиевского

Русская литература ХVIII и ХIX столетий

8 Троицкий В. Ю. Национальное самосознание в русской поэзии 1816-1821 гг.

36 Виноградов И. А. Славянофил-государственник. Н. В. Гоголь в движениях эпохи

62 Вишневская Е. Э. Рукописное собрание В. Ф. Одоевского как источник по изучению теории древнерусского пения

78 Вихрова Н. Н. И. С. Аксаков о монастырях и монашестве (по материалам переписки с женой)

94 Фетисенко О. Л. Четыре Лавры: монастырская тема в художественном, публицистическом и эпистолярном наследии Кохановской (Н. С. Соханской)

110 Мельник В. И. Логика творчества И. А. Гончарова: к постановке проблемы

144 Ермолаева Н. Л. Петербург, Москва, провинция в творчестве А. Н. Островского и И. А. Гончарова

174 Кавацца А. Образ Марии Египетской в творчестве Ф. М. Достоевского

Научная жизнь

186 Донсков А. А. Славянская исследовательская группа в университете г. Оттава

196 Андреева В. Г. Текстологические сюжеты русской классики: актуальные решения 


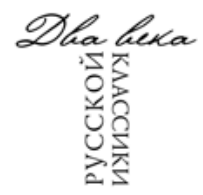

\section{Contents}

6 In memory of P. V. Palievsky

Russian literature XVIII and XIX centuries

8 Troitsky V. Yu. National identity in Russian poetry 1816-1821

36 Vinogradov I. A. Slavophil-statesmen. N. V. Gogol in the movements of the epoch

62 Vishnevskaya E. E. Manuscript collection of V. F. Odoyevsky, as a source for studying the theory of ancient Russian singing

78 Vikhrova N. N. I. S. Aksakov about monasteries and monasticism (on materials of the correspondence with his wife)

94 Fetisenko O. L. Four Laurels: a monastic theme in the artistic, journalistic and epistolary heritage of Kokhanovskaya (N. S. Sokhanskaya)

110 Melnik V. I. Logician of creativity I. A. Goncharov: to statement of a problem

144 Ermolaeva N. L. Saint-Petersburg, Moscow, Province in the creative work of I. A. Goncharov and A. N. Ostrovsky

174 A. Kavazza The image of Mary of Egypt in the work of F. M. Dostoevsky

Scientific Life

186 Donskov A. A. Slavic research group at the University of Ottawa

196 Andreeva V. G. Textological subjects of Russian classics: actual solutions 


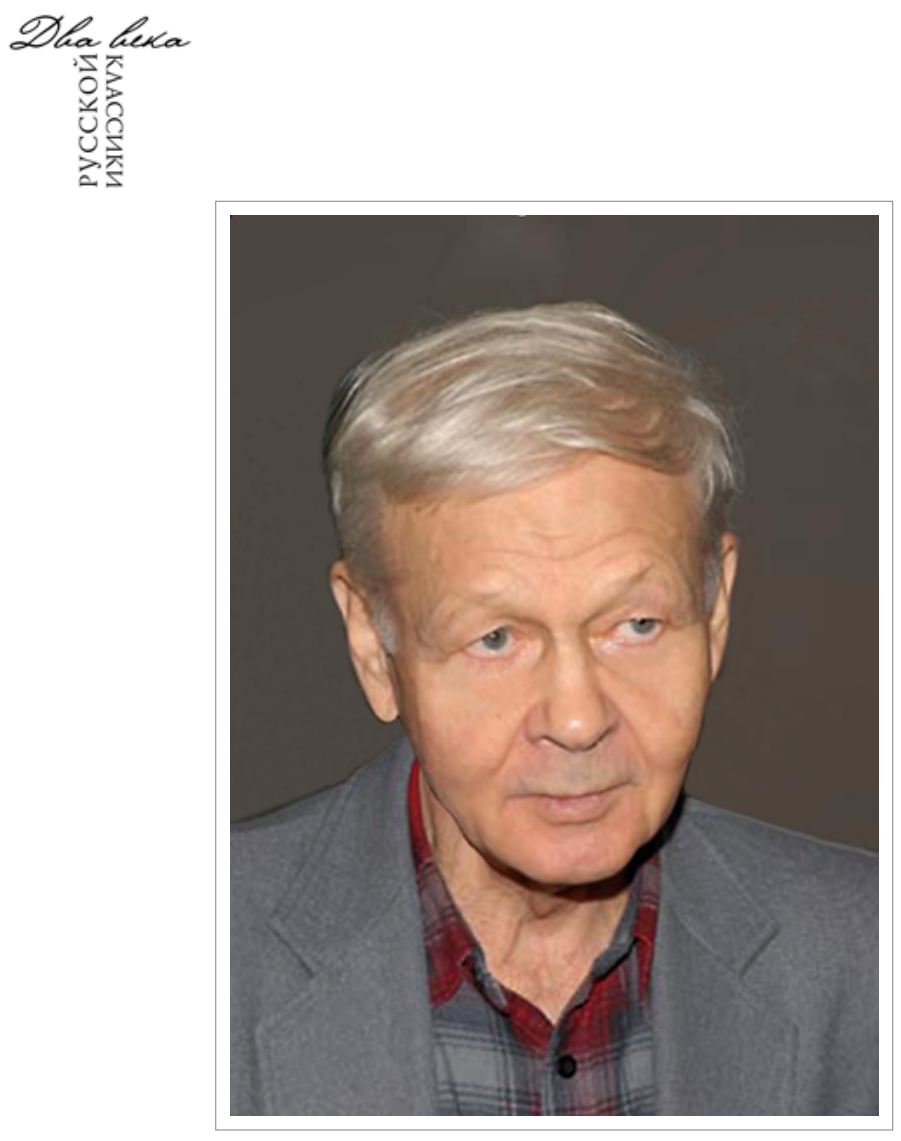

\section{Памяти П. В. Палиевского}

8 октября 2019 г. на 88-м году жизни закончился земной путь Петра Васильевича Палиевского. От нас ушел ученый с мировым именем, человек, без которого невозможно представить себе 60 лет истории Института мировой литературы.

Доктор филологических наук, в разные годы - заместитель директора ИМЛИ РАН по науке, главный научный сотрудник Отделов теории литературы и русской классической литературы, Петр Васильевич до своих последних месяцев принимал деятельное участие в судьбе Института. Его блестящее научное дарование - всегда неотделимое от высокого идеала гражданского служения, его превосходный организа- 
торский талант - всегда гуманный и проницательный, оставили неизгладимый след в академической филологии. Очень значимо и велико научное наследие П. В. Палиевского. А сам Петр Васильевич был очень самобытной личностью, одним из важнейших духовных центров жизни ИМЛИ.

Ученый исключительного диапазона П. В. Палиевский получил широкое признание в России и за рубежом в качестве автора исследований, ставших классическими. Чрезвычайно велик его вклад в теорию литературного образа, изучение природы художественных ценностей, выявление закономерностей литературного процесса. Вместе с тем теоретические достижения Петра Васильевича нашли свое продолжение в углубленном, нетривиальном изучении Пушкина и Льва Толстого, Леонтьева и Розанова, Шолохова и Булгакова, Фолкнера и Грэма Грина, Замятина и Хаксли. Органичными свойствами его исследований всегда выступали образцовая логика, масштабность и отточенность мысли, верность национальной научной традиции.

Деятельность П. В. Палиевского в течение долгих лет была несомненным ориентиром для многих ученых близкого ему и последующих поколений. Десятки российских и зарубежных специалистов обращались к нему за консультациями по самому широкому кругу научных проблем. Исключительно плодотворной была работа Петра Васильевича на протяжении последней четверти века в Отделе русской классической литературы ИМЛИ.

Обладая ярким талантом публициста и литературного критика, П. В. Палиевский с начала 1960-х гг. получил широкую известность как неравнодушный к судьбе России участник полемики о ценностях национального мира, о прошлом и будущем страны. Он принимал заметное участие в русском патриотическом движении, был одним из создателей «Русского клуба» и Советско-болгарского клуба творческой молодежи, где объединились многие будущие видные российские идеологи. Ему по праву принадлежит единственное место в истории российской общественной мысли второй половины XX в.

Значение П. В. Палиевского в судьбе ИМЛИ, в развитии отечественной и мировой филологии, в идейном движении русского мира неповторимо и бесценно.

Светлая память о Петре Васильевиче Палиевском навсегда сохранится в наших сердцах... 


\section{(c) 2019. В. Ю. Троицкий}

г. Москва, Россия

\section{Национальное самосознание в русской поэзии 1816-1821 гг.}

Аннотация: Статья посвящена русской поэзии 1816-1820-х гг., путям и формам выражения национального самосознания в литературе указанного времени. В течение нескольких лет после Отечественной войны в русской литературе отражался пафос большой победы, радостные чувства. Обращаясь к стихотворениям Вяземского и Жуковского, автор статьи рассматривает воплощенные в них лучшие коренные черты русского национального характера - незлобие, милосердие. Высота нравственного чувства признаётся поэтами первейшим достоинством не только в мирное время, но и в любой чрезвычайной обстановке, в том числе и во время военных действий. В статье отмечается, что самосознание и настроение русского общества после победы над Наполеоном, при всём разнообразии мнений, сосредоточивалось на чувстве народного единения. Однако сложная внутренняя жизнь нации требовала уже не только ответов на уровне политических оценок, но духовно-нравственного бдения, движения мыслей и чувств. В работе дается представление о пути России и осмыслении ее миссии в стихотворениях русских поэтов, об образе государя, отношении к нему. Автор анализирует религиозные мотивы в творчестве ряда русских поэтов, а также И. А. Крылова, мораль которого, могущая показаться на первый взгляд несколько поверхностной, на самом деле, является глубоко связанной с православными ценностями, утверждает их.

Ключевble слова: русская поэзия, Отечественная война, национальные ценности, самосознание, духовно-нравственные основы, Пушкин, Вяземский, Жуковский, Батюшков, Крылов

Информация об авторе: Троицкий Всеволод Юрьевич, доктор филологических наук, профессор, академик Российской народной академии наук, Институт мировой литературы им. А. М. Горького Российской академии наук, ул. Поварская, д. 25а, 121069 , г. Москва, Россия

E-mail: info@imli.ru

Дата поступления статьи в редакиию: 14.08 .2019

Дата публикации статьи: 10.12.2019

Для цитирования: Троицкий В. Ю. Национальное самосознание в русской поэзии 1816-1821 гг. // Два века русской классики. 2019. Т. 1. № 2. С. 08-35. DOI 10.22455/2686-7494-2019-1-2-08-35 


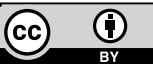

This is an open access article distributed under the Creative

Commons Attribution 4.0

International (CC BY 4.0)

\title{
National identity in Russian poetry 1816-1821
}

\begin{abstract}
The article is devoted to Russian poetry of the 1816-1820s, the ways and forms of expressing national identity in the literature of the indicated period. For several years after World War II, russian literature reflected the pathos of the great victory, joyful feelings. Appealing to the poems of Vyazemsky and Zhukovsky, the author of the article considers the best fundamental features of the Russian national character embodied in them - kindness, mercy. The height of morality is recognized by poets is recognized by poets as the first dignity not only in peacetime, but also in any emergency, including time of hostilities. The article notes that the self- consciousness and the mood of Russian society after the victory over Napoleon, with all the diversity of opinions, focused on a sense of national unity. However, the complex inner life of the nation required not only answers at the level of political assessments, but also a spiritual and moral vigil, the movements of thoughts and feelings. The work gives an idea of the Russian path and the interpretation of its mission in the poems of Russian poets, the image of the sovereign, the attitude towards him. The author analyzes the religious motives in the works of a number of Russian poets, including I. A. Krylov, whose morality, which at first glance seems somewhat superficial, in fact, is deeply connected with Orthodox values, confirms them.
\end{abstract}

Keywords: Russian poetry, World War, national values, self-awareness, spiritual and moral foundations, Pushkin, Vyazemsky, Zhukovsky, Batyushkov, Krylov

Information about the author: Troitsky Vsevolod Yuryevich, DSc in Philology, Professor, A. M. Gorky institute of World Literature of the Russian Academy of Sciences, Povarskaya 25a, 121069, Moscow, Russia

E-mail: info@imli.ru

Received: August 14, 2019

Published: December 10, 2019

For citation: Troitsky V. Yu. National identity in Russian poetry 1816-1821. Two centuries of the Russian classics, 2019, vol. 1, № 2, pp. 08-35. (In Russ.) DOI 10.22455/2686-7494-2019-1-2-08-35 
Представление о литературе прошлого нередко несёт на себе отпечаток субъективных мнений её толкователей. Поэтому необходимо взглянуть на неё глазами тех, кто были её творцами, имея в виду их переживания и суждения о современных им событиях национальной истории. Предметом нашего рассмотрения будет русская поэзия 1816-1820-х гг., а именно - пути и формы выражения национального самосознания в русской поэзии этих лет. Эта тема особенно актуальна в современных условиях, при целенаправленном и интенсивном распространении ложных мнений об истории, активно внедряемых системой глобалистской дезинформации.

Состояние национального сознания по окончании Отечественной войны 1812 г. было периодом переосмысления жизни, когда многое стало восприниматься в свете победного завершения освободительного похода в Европу. Осознание происшедшего совершалось по-разному, хотя и в русле основных национальных представлений и традиций, иногда вполне сливаясь с ними, иногда от них отталкиваясь. Сложная внутренняя жизнь нации требовала осмысления и отклика не только на уровне политических оценок, но более всего - со стороны внутренних духовно-нравственных движений мысли и чувства, со стороны характера мироощущения и поведения личности в период противоречивых на неё воздействий, непривычных обстоятельств и часто привнесённых извне идей. Новые, далеко не всегда соприродные национальным традициям представления, с одной стороны, искушали своею новизной и усваивались восприимчивым русским сознанием как то, что представляет собой недостигнутую ступень, некий новый уровень, с другой - такие представления нередко вызывали внутреннее сопротивление не только своею непривычностью, но и чужеродностью тем устоям, которые составляли коренные, органические черты национального мировосприятия. 
Спустя два года после знаменательного дня, торжественно завершившего ответный поход русских войск в Европу, настроение русского общества всё ещё было насыщено отзвуками того победного времени. Свидетели православного торжества 29 марта (11 марта) 1814 г. помнили царя Александра I, стоящего на площади Согласия перед походным алтарём. Он был установлен на месте, где в 1793 г. был казнён христианский король Людовик XVI и где в день коронации Наполеона в 1804 г. пламенела красная пятиконечная звезда, символ масонства. «В ту пасхальную ночь на площади стояли батальоны православного воинства и полковые священники возглашали: “Христос Воскресе!”, на что многотысячный хор русских ратников отвечал: “Воистину Воскресе!”» [Кубенский: 98].

О незабвенный день! Смотрите - победитель

С обезоруженным от ужаса челом,

Коленопреклонён на страшном месте том,

Где царский мученик под острием секиры

В виду разорванной отцов своих порфиры

Молил Всевышнего за бедный свой народ,

Где на дымящийся убийством эшафот

Злодейство бледную свободу возводило,

И Бога поразить своей хулою мнило, -

На страшном месте том смиренный вождь царей

Пред миротворною святыней алтарей

Велит своим полкам склонить знамёна мщенья [Жуковский: 207].

Незабываемые дни сами по себе были словно воплощением высокой одической поэзии, торжеством православного духа. Этот вдохновенный патетический настрой сохранился в литературе и к 1816 г. Но в поэзии этого времени отчётливей слышались иные ноты: православное умиротворение и человеческое сочувствие тем, кто несколько лет до того явился в Россию завоевателем среди солдат наполеоновской армии; добрая благожелательность и человеческое отношение к недавнему врагу утверждали традиционные черты русского характера. Эти черты ещё накануне 1816 г. были запечатлены А. С. Пушкиным в «Воспоминании в Царском Селе»: 
Утешься, мать градов России,

Воззри на гибель пришлеца,

Отяготела днесь на их надменны выи

Десница мстящая творца.

Взгляни: они бегут, озреться не дерзают,

Их кровь не престаёт в снегах реками течь;

Бегут - и в тьме ночной их глад и смерть сретают,

А с тыла гонит русский меч...

В Париже росс! — где факел мщенья?

Поникни, Галлия, главой.

Но что я вижу? Росс с улыбкой примиренья

Грядёт с оливою златой.

Ещё военный гром грохочет в отдаленье,

Москва в унынии, как степь в полнощной мгле,

А он - несёт врагу не гибель, но спасенье

И благотворный мир земле» [Пушкин: 88].

Созвучное с этим пожелание П. А. Вяземского итальянцу, возвращающемуся в Отечество, исполнено не только мирных, но и дружественных чувств:

Да жизни пред тобой всегда светлеет путь,

Да радость и любовь чело твоё венчает,

Но северных снегов не позабудь!

В стране, где гордый Тибр златые катит воды,

Где Капитолиум вознёс свою главу,

Воспомни прах Кремля, сей памятник свободы,

Воспомни славную в падении Москву!

Иди, куда тебя отца зовут моленья;

В объятиях согрей ты старческую грудь,

Но в первой радости любви и умиленья

Нас, северных друзей, не позабудь [Вяземский: 173].

Так, в стихотворении П. А. Вяземского проявляется типическая черта русского национального характера - незлобие, многочисленные примеры которого и в грозные дни Отечественной войны 1812 г. 
были всем хорошо известны. Те же настроения и та же мысль сквозит в стихотворении В. А. Жуковского «На первое отречение от престола Бонапарта».

Те же настроения и та же мысль сквозит в стихотворении В. А. Жуковского «На первое отречение от престола Бонапарта»:

И честь тому — кто верный чести,

Свободе меч свой посвятил,

Кто в грозную минуту мести

Лишь благодатию отметил...(1816) [Жуковский: 271]

Истинная слава неразрывна в русском национальном сознании с православным представлением о милосердии, о любви к добру и смирении перед Промыслом, дающим победу. Поэтому победителю не пристало кичиться своим превосходством. Таков пафос стихотворения Жуковского «Императору Александру»:

О русская земля! Спасителем грядёт

Твой царь к низринувшим царей твоих столицу;

Он распростёр на них пощады багряницу;

И мирно славу скрыв, без блеска, без громов,

По стогнам радостным ряды его полков

Идут - и тишина вослед им прилетает...

Хвала! хвала, наш Царь! стыдливо отклоняет

Рука твоя побед торжественный венец!

Ты предстоишь благий самих врагов отец,

И первый их с землёй и с небом примиритель...

...О Вечный! Осени смиренного державу;

Его душа чиста: в ней благость лишь одна,

Лишь пламенем к добру она воспалена... [Жуковский: 208].

Эти же настроения свойственны и И. М. Долгорукому, воспевающему современников и, несомненно, намекающему на события, связанные с завершившейся недавно кампанией: 
...Чья слава может во вселенной

Равняться с подвигом того,

Который склонностью врожденной

Удобен жертвою всего:

Отвесть злодея мстящу руку,

Смягчить страдальца тяжку муку,

И грудь его к своей прижать?

Не чванства гордыми хвалами,

Но благодарности слезами

Трофей негибнущий стяжать [Долгоруков: 98].

Как и в предшествующих стихах, здесь указаны коренные черты русского национального характера - великодушие и милосердие, называемые «склонностью врожденной». Именно высота нравственного чувства признаётся русскими поэтами первейшим достоинством не только в мирное время, но и в любой чрезвычайной обстановке, в том числе и во время военных действий. Такой традиционный взгляд на мир, свойственный русским людям, невольно обращает нас к уже упоминавшемуся ранее стихотворению В. А. Жуковского «Певец во стане русских воинов», в котором после одических славословий достойным всяческих почестей и похвал русским полководцам, вождям русской армии, выступившей против наполеоновских захватчиков-поработителей, - слышатся слова примирительные, обращающие всех и каждого к духовной брани, к исполнению нравственного долга, без которого все военные победы неизменно падают в цене и даже вовсе обесцениваются в глазах русского человека:

А мы?.. Доверенность к Творцу!

Что 6 ни было - незримый

Ведёт нас к лучшему концу

Стезёй непостижимой.

Ему, друзья, отважно вслед!

Прочь, низкое! Прочь, злоба!

Дух бодрый на дороге бед,

До самой двери гроба;

В высокой доле - простота;

Нежадность - в наслажденье; 
В союзе с ровным - правота,

В могуществе - смиренье.

Обетам - вечность; чести - честь;

Покорность - правой власти;

Для дружбы - всё, что в мире есть;

Любви - весь пламень страсти;

Утеха - скорби; просьбе - дань,

Погибели - спасенье;

Могущему пороку - брань,

Бессильному - презренье;

Неправде - грозный правды глас;

Заслуге - воздаянье... [Жуковский: 164].

Эти строки в известном отношении передают основной пафос нравственного сознания русского человека и, конечно же, - пафос русской поэзии. Читая их, глубже осознаёшь проницательные слова В. Г. Белинского о поэте, который дал «русской поэзии душу и сердце». Во всём этом отразилась и особенность русского мировосприятия, освящённого прежде всего душевно-духовным и сердечным отношением к миру, в чём постоянно приходится убеждаться, читая русскую поэзию, в том числе - первых десятилетий XIX в. Вполне созвучны в этом отношении поэзии В. А. Жуковского и стихи К. Н. Батюшкова «Мой гений» (1816):

О память сердца! Ты сильней

Рассудка памяти печальной,

И часто сладостью своей

Меня в стране пленяешь дальной [Батюшков: 220].

Для поэта «память сердца», соприродная духовной культуре и культуре чувств, не только сильней, но значительней самых умных умствований, ибо в ней отражён опыт непосредственных человеческих эмоций и впечатлений, которые гораздо глубже, чем меняющиеся со временем мнения, чем сиюминутный взлёт мысли, самонадеянный плод текущих представлений и рассуждений, готовых смениться другими, как только рассудок доставит новые доводы размышлению. Поэтому в стихотворении «Пробуждение» (1816) поэт возвращается к 
аналогичной мысли, отдавая предпочтение добродетелям сердца перед добродетелями ума:

...Ничто души не веселит,

Души, встревоженной мечтами,

И гордый ум не победит

Любви холодными словами... [Батюшков: 231]

И в этом вовсе нет, в сущности, унижения ума, но выражена поэтически мысль о непреходящем, а иногда и определяющем значении «памяти сердца», гораздо теснее и глубже связанной с преданием, чем наблюдения холодного рассудка.

Предание как форма воплощения культурной традиции, сосредоточивая богатый духовный исторический опыт, содержит то ценное, что значительней и выше мысленного суда, рассудка, ограниченного временем, своими возможностями и политическими пристрастиями. Ибо оно вмещает существеннейшую часть исторического опыта поколений, те озарения и открытия, которые становятся путеводною звездою к истине исторического пути народа. Неслучайно всё большее внимание поэтов привлекают полотна из отечественной истории; на них возрастает сознание исторического бытия как непременной основы национального сознания.

К этому времени во взглядах русского общества уже вполне утвердилась убеждённость во всемирно-историческом значении событий, в которых принимает участие Россия. Среди характерных в этом отношении стихотворений - «Переход через Рейн» (181\#-1817) К. Н. Батюшкова.

Начинающееся с воссоздания восторженного настроения воина-участника похода, оно развёртывается в широкую панораму исторических картин, возникающих в воображении поэта. В движении событий, в смене лет и эпох проходят перед читателем одна за другой картины прошлого, образы «событий всех времён». Тут и период римского владычества, здесь и следы великого Цезаря, знаменитые военные победы которого обращают воспоминание к этим же рейнским местам. Наконец в этих же местах утверждалось на путях христианства легендарное рыцарство, с его кодексом чести, оставшемся как предание в памяти народов. 
Века минули: мир крестом преображён;

Любовь и честь в душах суровых пробудились, -

Здесь витязи вооружились

Копьём за жизнь сирот, за честь прелестных жён;

Тут совершались их турниры,

Тут бились храбрые - и здесь

Не умер, мнится, и поднесь

Звук сладкий трубадуров лиры [Батюшков: 320].

Этот край - одна из важнейших областей, в которой происходили события европейской истории и уже потому достойны поэтического воссоздания, «и вид полей, и вид священных вод, / Туманной древности и бардам современных, / Для чувств и мыслей дерзновенных / И силу новую, и крылья придаёт» [Батюшков: 321].

Такие чувства и такое отношение свидетельствуют не только о понимании, но об осознанном переживании европейской истории, воспринимающейся мыслью русского поэта как соприродная ему, как история народов, среди которых и его народ занимает достойное место. Такое восприятие позволяет глубоко чувствовать отношение к событиям и настроениям недавнего прошлого, когда берега здешних вод стенали под ордами нового Атиллы-Наполеона:

Давно ли земледел вдоль красных берегов,

Средь виноградников заветных и священных,

Полки встречал иноплеменных

И ненавистный взор зарейнских сынов? [Батюшков: 322].

Тем очевиднее для поэта и читателя то восторженное настроение, которое совместно испытали освободители и освобождённые, когда настал «час судьбы» и «под знаменем Москвы, с свободой и громами» воины России

Стеклись, нагрянули, за честь своих граждан, За честь твердынь и сёл, и нив опустошённых И берегов благословенных, Где расцвело в тиши блаженство Россиян, 
Где ангел мирный, светозарной, Для стран полуночи рождён

И провиденьем обличён

Царю, отчизне благодатной [Батюшков: 320].

Живая панорама движения полков по берегам Рейна, поросшим лесом; картины походной жизни и на привале нежданные встречи соотечественников, разлучённых в ратном деле, и походные сцены, исполненные массой предметных деталей полкового быта и тем не менее сохранившие главное, внутреннее, сокровенное настроение воинов, сердцем привязанных к далёкой Отчизне и к Господу, составляют внутреннее содержание стихотворения. Последние яркие сцены предшествующие изображению мощного движения рати, устремляющейся далее «по манию вождей», - отражают именно эти глубокие и сокровенные настроения русского войска, каждого ратника, думы которого неизменно обращены к Отчизне:

Быть может он воспоминает

Реку своих родимых мест -

И на груди свой медный крест

Невольно к сердцу прижимает... [Батюшков: 323].

Это внутреннее благоговение перед святым передано поэтом и в изображении молитвы воинства накануне продолжения похода:

Все крики бранные умолкли, и в рядах

Благоговение внезапу воцарилось,

Оружье долу преклонилось

И вождь и ратники чело склонили в прах:

Поют Владыке Вышней Силы,

Тебе, подателю побед,

Тебе, незаходимый свет!

Дымятся дымные кадилы [Батюшков: 324].

Только воссоздание внутреннего настроя ратников в сокровенном слиянии чувств, исполненных святою верою и неизменной любовью к далёкой отчизне, - даёт истинное переживание смысла последних 
строк стихотворения, обращённого к Рейну, по берегам которого движутся воины-освободители:

Твой стонет брег гостеприимной,

И мост под воями дрожит!

И враг, завидя их бежит

От глаз в дали теряясь дымной! [Батюшков: 324]

С этим внутренним настроением и осуществляются провиденциальные судьбы людей и народов на их историческом пути, мгновение которого запечатлено здесь К. Н. Батюшковым.

Исторический путь свершается благодатно, если народу присуще чувство долга и он следует священному преданию. В упомянутом стихотворении В. А. Жуковского «Императору Александру» народ становится победителем, ибо он «могучий и смиренный», величие его обеспечивает правда-справедливость благих целей и усилий, которыми он живёт:

И грозно в бой пошла с насилием свобода!

Тогда явилось всё величие народа,

Спасающего трон и святость алтаря алтарей,

И тихий гроб отцов, и колыбель детей

И старцев седины, и младость дев цветущих,

И славу прежних лет, и славу лет грядущих. [Жуковский: 203].

Но народам, пренебрегающим законом, провозглашает в своём стихотворении один из современных Жуковскому стихотворцев, даже сама «Европа изумлена» бросает горькие укоризны:

Вы, чада Франции, я призываю вас,

Вы, человеки: - вы услышите мой глас!..

Доколе будете кровь ближних лить рекой

И грудь мне раздирать злодейскою рукой?

...Французы! Долго ль вам врагами быть вселенной?

Доколь народов всех проклятие носить?.. [Авраамов: 6].

Продолжая свои упрёки французам, Европа напоминает им о безумных походах и войнах, памятниках их высокомерной злобы, о полях 
сражений, приявших «тьмы братий падших там», наконец - обращается к причине всех зол, олицетворяя их в образе единого человека, принесшего французам «народов ненависть, в семействах токи слёз». Далее следует - воззвание к царю Россов с призывом - сокрушить злобу и заверение в том, что если бы этого не произошло, - несчастья охватили бы всю Европу, захлёстнутую безнравственностью и беззаконием:

Ах, внедрится тогда безбожная свобода

В грудь каждого ему подвластного народа;

И идолу сему на жертву принесут

Не брение одно, но честность, правый суд,

Невинность, простоту, стыд, совесть, добры нравы,

Согласие семейств, общественны уставы,

Приверженность к царям, к отечеству любовь... [Авраамов: 20].

Речь, как видим, идёт не о свободе, духовно освящённой, но о «безбожной свободе», об идоле свободы, которому приносятся в жертву добродетели: невинность, стыд, «добры нравы», общественные установления, наконец, - преданность царю и Отечеству. Поэтому возникают в стихах поэтов той поры страстные призывы к потомкам - быть верными преданию, как, например, в элегии М. Лобанова «При гробе князя Смоленского»:

...О сын мой! В сем храме над грозным сим прахом

Клянись - да сойду я спокойно во гроб -

Злодеев, как язвы, чуждаться со страхом,

Разливших по миру разврата потоп.

Примеры их - гибель; ученье - отрава:

Язык их хулою святынь изощрён.

Безбожье, измена и буйство - их слава:

Блюдись, да не будешь в их сеть уловлён... [Лобанов: 106].

У И. Долгорукого горячий порыв к верности Отечеству сочетается с молитвенно просьбою к Господу - укрепить народ в отеческой вере: 
...Всевышний! Ты явил и в рай и в ад пути;

Дай силу совести по первому идти,

На Камне Веры став! Потщимся мы в печалях

Глубоко начертать на умственных скрижалях

Урок Спасителя, идущего на страсть!

Бди крепко - и молись - да не впадёшь в напасть! [Долгоруков:116]

Подобные проникнутые светлой верою настроения сопровождают патриотическую лирику тех лет. Таково и «Благодарение Всевышнему, даровавшему победу на всеобщего врага» И. Е. Срезневского:

К Тебе, Господь, моё моленье

Мы воссылали в лютых днях;

Тебе теперь благодаренье

Приносим в наших торжествах

Ты нас любя и наказуя

И днесь на нас врага послал;

Но славу нашу показуя,

Над ним победу даровал... [Срезневский: 74-75]

Победа, дарованная народу, воспринимается поэтами как благодатная, ибо она соприродна благим, то есть добрым помыслам победителей. О сохранении и утверждении этих добрых помыслов и воссылаются мольбы ко Господу как, например, в стихах В. А. Жуковского 1818 г., входящих в письмо А. И. Тургенева князю П. А. Вяземскому. «В богатый замен письма, которое я не успел кончить по милости Жуковского, — пишет А. И. Тургенев, — вот тебе стихи его, которые он прибавил к гимну «Боже, царя храни...»:

Перводержавную

Русь православную,

Боже, храни!

Царство ей стройное

В силе спокойное!

Всё ж недостойное

Прочь отжени! 
Воинство бранное,

Славой избранное,

Боже, храни!

Воинам - мстителям,

Чести спасителям

Миротворителям -

Долгие дни.

Мирных воителей,

Правды блюстителей,

Боже, храни!

Жизнь их примерную,

Нелицемерную,

Доблестью верную

Воспомяни.

О, Провидение!

Благословение

Нам ниспошли.

К благу стремление,

В скорби терпение

Дай на земли!... ${ }^{1}$

Итак, победа и слава в русском национальном самосознании неизменно связываются с понятиями: добро, справедливость, истинная свобода, любовь, милосердие, благочестие, - короче - с понятиями добродетели и блага ближнему и, кроме того, с понятиями долга как необходимой личной причастности к общему благому делу. И поэтому все лирические сцены, отражённые в поэзии тех лет, как правило, пронизаны мыслью о том, что нет ничего земного выше любви к Отечеству. Так, например, стихотворение В. Раевского «Прощание воина с милой», в котором лирический диалог воина, собирающегося в ратный поход, и его возлюбленной, сетующей о предстоящей разлуке, завершается словами, обращёнными к деве:

Россиянке ли страшиться

Друга в брани потерять.

1 Письмо А. И. Тургенева кн. П. А. Вяземскому. 22 ноября 1819 г. // Остафьевский архив князей Вяземских. Т. 1. Спб. 1899. С. 176-177. 
Есть ли здесь мы разлучимся, увидимся опять [Раевский: 89].

Подобные настроения и образы типичны для русской поэзии. Таковы и «романс» Д. Глебова (1817), «Прощание Славянки с любимым, отъезжающим на войну» П. Политковского (1818) и др.

Парижский триумф 1815 г., патриотический порыв тех памятных лет, когда молодой император, победитель Наполеона, стал во главе Священного Союза, объединившего христианских государей Европы в их противостоянии «слугам антихриста»; Ахенский (1818), а затем и Троппауский (1820) съезды союзников, - всё это вполне отвечало национальному единению на основе самодержавного мироустроения, тому единству, в основе которого было ощущения державной имперской России и верноподданности православному государю. В известной части общества образ царя-воина, царя-освободителя, сеющего щедрою рукою добро, милосердного к врагам и отзывчивого к нуждам Отечества, в это время достиг своего апогея.

Самосознание и настроение русского общества после победы над Наполеоном, при всём разнообразии мнений, сосредоточивалось на чувстве народного единения. Неслучайно 1 января 1816 г. был опубликован «Манифест Высокомонаршей признательности народу за оказанные в продолжении войны подвиги». В этом манифесте, несомненно нелицеприятном документе, имелась в виду всесословная Россия, всё многосословное общество, в котором господствовал «русский дух». Это качество, чуждое социально-классовым представлениям об обществе, реально проявилось в годы испытаний Отечественной войны и послужило цементирующим основанием в период, ближайший после её победоносного завершения.

Здесь невольно вспоминаются слова, сказанные много позже знатоком русской истории И. Е. Забелиным: «Русский дух пошире сословной вражды, сословных интересов» [Забелин: 11]. Однако же несмотря на известное единство настроений, уже к 1816 г. в обществе были заметны признаки недовольства, указывающие на противоречия императора «с общественным мнением и особенно с армией после окончания военных действий, вызванных нежеланием правительства проводить либеральные реформы» [Ячменихин: 40]. В известной степени это настроение были следствием влияния западных «либеральных» идей, 
подпитанных заграничными контактами во время антинаполеоновского похода в Европу. Эти во многом умозрительно воспринятые идеи не соотносились, как правило, с традициями и условиями русской действительности и были скорее соблазном, чем примером для разумного заимствования. Однако они возбуждали смутные настроения.

Вместе с тем православный царь как помазанник Божий, царь-батюшка, раб Царя Небесного и исполнитель Его воли в защите христианских святынь и монархий, - представал в народном сознании современников в известного рода политической и поэтической завершённости. Неслучайно вызревает идея «административного оформления» государственной веры, нашедшая выражение в Манифесте об учреждении Министерства духовных дел и народного просвещения $(1817)^{1}$.

В. А. Жуковский был одним из тех, кто наиболее откровенно выразил свои нелицеприятные для тех лет, искренние чувства любви к государю:

О дивный век, когда певец Царя - не льстец,

Когда хвала - восторг, глас лиры - глас народа;

Когда всё сладкое для сердца: честь, свобода,

Великость, слава, мир, отечество, алтарь -

Всё, всё слилось в одно святое слово: Царь! [Жуковский: 210].

Несомненная искренность поэта зиждилась на глубокой религиозной вере и убеждённости в том, что Государь - помазанник Божий; ведь именно в прошедшей войне с антихристом-Наполеоном он определённо стал представителем православного мира, исполняющим миссию православного царя. Этим и объясняется непосредственность поэтически выраженных сокровенных чувств поэта.

Непосредственное, духовное чувство любви к России и государю, ведомое русскому сердцу, в полноте своей недоступно пониманию чужеземцев; оно непонятно и невольникам своих страстей, расчётов

1 Это министерство не оправдало возлагавшихся на него надежд, ибо стало центром консолидации антиправославных духовных «исканий» в масонском духе, чему более всего способствовал министр, князь А. Н. Голицын, бывший одновременно сенатором и членом Государственного Совета. В конце концов Александр I был вынужден закрыть министерство. 
и выгод, лишённых чистосердечного порыва. Об этом и писал князь И. М. Долгоруков:

О вы, ревнующие доле

Благополучных наших стран

И влачущиеся в неволе!

Познайте сердце Россиян!

Не сила скиптра нас лишь клонит,

Не бич на ратно поле гонит,

Как стадо трепетных овец:

Из царских уст довольно слова,

Народ в ружьё - вся Русь готова, -

Не страшен жизни нам конец [Долгоруков: 79].

То же настроение в стихотворении Фёдора Глинки:

Служа в полях под знамем чести

Не знает русский воин лести.

...О Царь! Наш вождь, надежда наша!

Тебе сия заздравна чаша!

Мы выпьем так, как пили деды,

За край родимый, за царя,

Как пили сами - в дни победы,

Когда кровавая заря

Над полем битвы в тучах рдела

И смерть на всех равно глядела [Глинка: 117-118].

В его же стихотворении «Песня Русских воинов перед сражением» (1817) вновь звучат мысли, связывающие воедино царя и Россию: «Друзья! На смертный пир! / За честь царя, отчизны / Жалеть не должно жизни...». То же и в прощальной песне воспитанников императорского Царскосельского лицея» А. А. Дельвига, у Б. Фёдорова в стихотворении «Дифирамб» (1818).

Славословие императору не было лестью, ибо среди мыслящей части общества большинство составляли те, кто был безусловно убеждён: «только сею любовью к Отечеству производятся великие люди» 
[Свиньин: 142]. Между тем освобождение России от наполеоновского нашествия и ещё в большей степени - завершение победного похода в Европу прочно связывалось с именем царя Александра I. И его имя, освящённое верою, воспринимало отблеск этой веры.

Одновременно чужеродные семена неверия и либерализма то там, то здесь давали свои плоды, и к концу 1810-х гг. уже можно было заметить, что в поэзии, вдохновлённой национальным сознанием единства, блага, славы и веры, появлялись тревожные нотки по поводу нигилистических идей, подтачивающих основы русского державного самосознания. Наконец, в отдельных стихах некоторых поэтов проскальзывают и бунтарские мотивы, отражавшие зачастую рост чужеземных влияний. В записках Ф. Ф. Вигеля эти процессы достаточно точно определены: «Я видел, как прежний розовый цвет либерализма стал густеть и к осени переходить в кроваво-красный...». И далее повествует о том, как «в одном холостом, о весёлом обществе, где было много офицеров» вдруг запели «на голос известной в самые ужасные дни революции песни» «Vaillons au salut de l’ empire» («Будем на страже спасения Империи»); богомерзкие слова её, переведённые надменным и жалким поэтом (слова эти, несомненно, выражают отношение Ф. Ф. Вигеля к политическому содержанию песни. - В. Т.) полковником Катениным по какому-то неудовольствию недавно оставившим службу $<\ldots>$ Они меня так поразили, что остались у меня в памяти, и я передаю их здесь, хотя не ручаюсь за верность» [Вигель: 159]. Вигель, надо полагать, слышал катенинский гимн в 1820 г., хотя он был написан, вероятно, несколько ранее. В нём уже ощущается преддверие декабристских настроений:

Отечество наше страдает

Под игом твоим, о, злодей.

Коль нас деспотизм угнетает,

То свергнем мы трон и царей.

Свобода! Свобода!

Ты царствуй над нами!

Ах, лучше смерть, чем жить рабами, -

Вот клятва каждого из нас [Катенин]. 
Среди писателей 1816-1821 годов, вполне выразивших важнейшие черты национального самосознания времени, возвышается монументальный образ И. А. Крылова. Основной жанр поэта - басня, на первый взгляд, представляется нейтральной к тому, что обычно имеют в виду под национальным самосознанием. Но даже в отношении политики это неверно. Отражённая в крыловском басенном творчестве многосторонность взглядов и отношений, характеры героев, типические столкновения и, наконец, своеобразие и тон моральных назиданий и басенных выводов, несомненно передавали отличительные черты национального самосознания. Сам подбор басенных сюжетов о многом говорил вдумчивому читателю.

Сегодня требуется новое осмысление крыловских басен и стоящих за ними значимых духовно-нравственных вопросов, тесно связанных с социальным бытием, с событиями быстротекущей жизни. Будучи жанром, обращённым к вечным человеческим противоречиям внутреннего мира личности, и самым общим принципам социального поведения, басня неизбежно отражает не только закономерности человеческих свойств и наиболее значимые черты тех или иных социальных проблем, но в неменьшей мере выражает национальное сознание, тем более, что в данном случае речь идёт о поэте, вполне признанном выразителем русского духа.

В означенный период И. А. Крылов написал 67 басен. Причём, значительную часть - в 1816 г. Такая творческая активность имеет, разумеется, не только субъективные причины. Но привязывать те или иные басни к определённым историческим событиям - значило бы «домысливать» их содержание. Представляется более правильным, вскрывая общий смысл басен, соотносить его с теми значительными и очевидными общественными явлениями, которые отражали типические процессы или исторические сдвиги, определившиеся характерными чертами национальной жизни того времени.

Крылов воплотил в своих баснях, говоря словами В. Г. Белинского, целую сторону русского национального духа. Русский характер, русский образ мыслей и выражений вполне воссоздан в его басенном творчестве. Его басни явились в известном смысле итогом представлений о русском народе, каков он есть в своей жизни и во взглядах на окружающий мир. В этом смысле все они - выражение русского национального мироотношения и самосознания. 
Одною из ранних крыловских басен этого периода (апрель 1816 г.) стала басня «Безбожники». Нам это представляется не случайным. Вопрос веры и неверия достаточно остро вставал в то время, когда влияние западного вольномыслия стало сказываться более заметно, чем ранее. Этому способствовала и некоторая самонадеянность, охватившая русские умы после великой победы и то пристрастие к земному миру, которое было обострено наблюдаемой участниками похода относительной «цивилизованностью» западной жизни, и вообще - переключением сознания на мирские дела, которых хватало каждому русскому человеку после разорительного наполеоновского нашествия, и обильные соблазнами заграничные впечатления.

Так или иначе, извечно крепкая вера, к которой было причастно безусловное большинство русского народа, убеждение в том, что жить - Богу служить, что сколько не мудри, а Божьей воли не перемудришь; что Богу молиться - вперёд пригодится, - все эти и другие истины народной веры, запечатлённые в народном сознании, стали восприниматься не ревностно, а спокойнее и даже иногда скептически. Дурной пример был заразителен. О такой заразительности дурного, то есть безбожия, и повествует И. А. Крылов.

Первое условие безбожия - ожесточённость, свойство, возникшее от несмирения и воинственного отношения к миру, от гордыни ума. Поводов к такому движению в настроениях было более чем достаточно, особенно же учитывая «вольные» нравы западного мира. Внешняя брань с врагом, с ратью антихриста, ослабила внутреннюю сосредоточенность на укладе жизни и внутренней духовной брани православного человека; это ослабление внутреннего смирения давало пищу вольномыслию, приближалось ощущение самовольной независимости, превышающее чувство гражданского долга. Вот настроение времени. Крылов уловил его. И предупредил о последствиях:

Был в древности народ, к стыду земных племён, Который до того в сердцах ожесточился, Что противу богов вооружился... [Крылов: 34]. 
Такой оценкой автор словно предвосхищает исход этого ожесточения, но затем развёртывает в мирских образах сцену восстания народа и смятения, какое вызывает среди богов богоборчество:

Мятежные толпы, за тысячью знамён,

Кто с луком, кто с пращёй, шумя, несутся в поле.

Зачинщики, из удалых голов,

Чтобы поджечь в народе буйства боле,

Кричат, что суд небес и строг и бестолков;

Что боги или спят, иль правят безрассудно;

Что проучить пора их без чинов... [Крылов: 34].

Эти богоборческие настроения окончательно ослепляют очи сердца, помрачают умы людские, и возникает страстное намерение и слепая уверенность,

Что, впрочем, с ближних гор каменьями не трудно

На небо дошвырнуть в богов... [Крылов: 34].

Смятение на Олимпе и обращение богов за помощью к Зевсу (Юпитеру) с просьбою громовой защиты от восставших толп завершается олимпийски спокойным его ответом:

«Пождём, -

Юпитер рек. - А если не смирятся

И в буйстве прекоснят, бессмертных не боясь,

Они от дел своих казнятся» [Крылов: 35$]$.

И неизбежное совершается: тучи стрел и камней «от войск богомятежных» низвергаются на головы богоборцев «с тысячью смертей, и злых и неизбежных». Мораль басни, предостерегающая от трагического финала растущих в обществе настроений, несёт пророчески обобщающий смысл:

Плоды неверия ужасны таковы;

И ведайте, народы, вы,

Что мнимых мудрецов кощунства толки смелы, 
Чем против божества вооружают вас,

Погибельный ваш приближают час,

И обратятся все в громовые вам стрелы [Крылов: 35].

Не менее определённо была высказана в басенном творчестве И. А. Крылова мысль о пагубности вольномысленных идей в устроении державной России. Писатель видел спасение в её традиционности и укоренённости в предании. Осознавая связь между неколебимостью самодержавной власти и прочностью устроения современной ему православной державы, писатель ощущал большую опасность в распространении либерализма западного толка, придерживаясь народной мудрости и по-народному считая, что на вожжах и лошадь умна, что хвост голове не указка, что без Бога свет не стоит, без царя земля не правится, наконец, будучи убеждён, что время, когда можно будет установить иной порядок, не настало, и ныне необходимо защищать идею «строго государственного правления, сильной руки». Ведь при всём духовном свободомыслии, свойственном русскому национальнеому сознанию, оно неотделимо от убеждённости, что вольному воля, ходячему путь; что волю дать - добра не видать, что воля портит, а неволя учит... Так или иначе, ощущение трезвой сдержанности при очередных мыслях о свободе в обществе было соприродно чувству народной осмотрительности, народной убеждённости, что, мол, крутая обочина недолго стоит; так гни, чтобы гнулось, а не так, чтоб лопнуло; не радуйся под гору: подъём круче...

В 1816 г. Крылов пишет басню «Конь и всадник», выразившую одну из типических сторон народного взгляда на власть и вольность. Это сознание отражено в наглядном басенном сюжете. Всадник приучил коня к безусловному послушанию, и тот «слушался его лишь слов». Но как только, надеясь на это послушание, «в поле выехав узду с коня он снял» —

Почувствовав свободу,

Сначала конь прибавил только ходу

Слегка,

И вскинув голову, потряхивая гривой,

Он выступкой пошёл игривой,

Как - будто теша седока. 
Но, сметя, как над ним управа не крепка,

Взял скоро волю конь ретивый,

Вскипела кровь его и разгорелся взор;

Не слушая слов всадниковых боле,

Он мчит во весь опор

Чрез всё широко поле... [Крылов: 116].

Ни слова, ни действия всадника теперь не оказывают на разнузданного коня никакого влияния, и он в конце концов сбрасывает седока, а сам «как буйный вихрь, пустился, / Не взвидя света и дорог, / Поколь в овраг со всех махнувших ног, / До смерти не убился...». Так, мнимая безграничная свобода приводит к двойной утрате: гибнет конь, символизирующий народ, и расшибается всадник...

Мораль басни высказана прямо и решительно:

Как ни приманчива свобода,

Но для народа

Не меньше гибельна она,

Когда разумная ей мера не дана [Крылов: 117].

Взгляд на благодатную жизнь как на бытие, основанное на разумной мере, убеждённость в том, что многого захочешь - последнее потеряешь, лишнее пожелать - последнее потерять, а завидущие глаза не знают стыда, что искушение на грех наводит, а от одного яблока воз загнивает - всё это вырабатывало особый взгляд на события и обстоятельства российской жизни, взгляд, отражающий состояние национального сознания того времени, когда новые революционные идеи стали распространяться в русском обществе. Это были идеи, возбуждающие к недовольству, настраивающие на возмущение, на решительное отвержение современного государственного уклада во имя неясного будущего. Это были идеи вольности, забывающей о жизнеустроительной дисциплине. Влияние этих идей было очевидно; они проникали в сознание через утопические картины инобытия, через «бытовые привычки», вольности поведения, порождённые неизвестными и несоприродными русскому уму историческими обстоятельствами и чуждой православному взгляду протестантской морали. Их опасность ощущали многие. Национальная интуиция по отношению к 
этим соблазнам нашла яркое выражение в басне И. А. Крылова «Сочинитель и Разбойник».

Содержание басни наглядно выражало её основную мысль и пафос: противостояние греху, возникающему через отрицание здравомыслия и добронравия. Одновременно представшие на суд в загробном мире грабитель, промышлявший по большим дорогам, и «славою покрытый Сочинитель», который «тонкий разливал в своих твореньях яд», немедля предаются наказанию. Под котлом с Разбойником Мегера разжигает «такой ужасный пламень / Что трескаться стал в сводах адских камень». Между тем

Суд к сочинителю, казалось, был не строг:

Под ним сперва чуть тлелся огонёк,

Но там, чем далее, тем боле разгорался;

Вот веки протекли, огонь не унимался.

Уж под Разбойником давно костёр погас;

Под Сочинителем он злей с часу на час... [Крылов: 179].

И стоило только сочинителю возвысить свой голос против будто бы несправедливого Божьего наказания, как перед ним является служительница преисподней «с шипящими между волос змеями / C кровавыми в руках бичами» и, обращаясь к казнимому, обличает его нераскаянные грехи.

Грехи эти продолжают распространяться и увеличивают год от года количество вновь возникающих и разрастающихся зол среди человечества. Ибо зло, согласно мысли народной, рождается о лжи и зла, а грешному путь лишь вначале широк, а после крут; ведь соблазн, как язва, поражает и человеческую душу; зло распространяется, как пожар, а соблазнители совершают двойной грех: они, кроме собственного порока, приводят к нему ещё других.

Ведь единственное средство избежать зла - это отвращать от него слух и зрение. Если разбойник-душегубец, совершив злодеяния при жизни, исчерпал им счёт, Сочинитель, который «вселял безверие, укоренял разврат» и по смерти продолжает сеять семена зла, в чём и обвиняет его Мегера, показывая, к чему ведёт чтение его соблазнительных произведений: 
Вот дети, стыд своих семей,

Отчаянье отцов и матерей:

Кем ум и сердце в них отравлены? - Тобою.

Кто, осмеяв как детские мечты,

Супружество, начальство, власти,

Им причитал в вину людские все напасти

И связи общества рвался расторгнуть? - Ты.

Не ты ли величал безверье просвещеньем?

Не ты ль в приманчивый, в прелестный вид облёк

И страсти и порок?

Как следствие всего этого - «целая страна», свидетельствует Мегера о Сочинителе, -

Полна

Убийствами и грабежами,

Раздорами и мятежами

И до погибели доведена тобой!

В ней каждой капли слёз и крови ты виной [Крылов: 180].

Таким образом «казни мера» оказывается вполне достойна Сочинителя, тем более, что поток зол, происходящих от его сочинений, - не убывает... Итак, басня эта столь же злободневна, как и предшествующие. Вольномысленное влияние западной цивилизации, и прежде всего вольтерьянства, романтический культ свободы, а иногда даже поэтически отождествляемого с ней узурпатора и «антихриста» Наполеона, не угасающие революционные настроения русского офицерства, а иногда недовольство солдат, вернувшихся из победоносного похода, рождали духовно-нравственные и политические колебания в обществе, приводящие не только к вольномыслию, но и к повреждению сословных нравов. И эти размышления не могли быть безопасны для внутреннего, да и в конечном счёте межгосударственного положения страны.

В условиях кипения общественного вольномыслия мнения об этой басне были различны. Если Н. И. Тургенев в 1817 г. на январском заседании Публичной библиотеки назвал её «лучшим плодом библиотеки», то П. А. Вяземский в 1824 г., отвечая настроениям разливающегося в 
обществе либерализма, называет басню эту подлой, считает её угождением нынешнему мнению (вероятно, официальному - B. Т.) и пишет, что басня эта ему тошна.

Однако же национально-исторический взгляд на события в целом совпадал именно с тем, что было выражено И. А. Крыловым. Национально-православное представление о человеке и мире, - всё блёстками мыслей-убеждений отражалось в его басенном творчестве второй половины 1810-х гг. Здесь, что ни басня, то картина, отражающая национальный взгляд на вещи.

\section{Список литературы}

1. Аврамов Матфб<ей>. Глас Европы при вероломном вступлении на берега Франции врага всемирныя и втрократном похищении её престола клятвопреступной дерзостью в 1815 г. М.: Университет. тип., 1815. 50 с.

2. Батюшков К. Н. Мой гений // Батюшков К. Н. Опыты в стихах и прозе. М.: Наука, 1977. 608 c.

3. Вигель Ф. Ф. Записки; ред. и вступительная ст. С. Я. Штрайха. М.: Круг, 1928. 387 с.

4. Вяземский П. А. Итальянцу, возвращающемуся из России // Собрание образцовых русских сочинений и переводов в стихах, изданные Обществом любителей отечественной словесности. Часть четвёртая. СПб., 1816.

5. Глинка Ф. Н. Стихи на 23 ноября // Сын Отечества. 1817. № 48. С. 117-118.

6. Долгоруков И. М. Бытие сердца моего, или Стихотворения князя Ивана Михайловича Долгорукаго: в 4 ч. М.: Университ. тип., 1817-1818. Ч. 1. 241 с.

7. Жуковский В. А. Собр. соч.: в 4 т. М.; Л.: Гослитиздат, 1959-1960. Т. 1.480 с.

8. Забелин И. Е. Дневники. Записные книжки. М.: Изд-во им. Сабашниковых, 2001. $383 \mathrm{c}$.

9. Катенин П. А. Отечество наше страдает. URL: http://stih.su/otechestvo-nashestradaet (дата обращения: 23.07.2019).

10. Крылов И. А. Басни: в 9 кн. М.-Л: Акад. Наук СССР, 1956. 635 с.

11. Кубенский А. (Рачинский А. В.) Император Александр I - победитель в первой глобальной войне // Щербатово (Марьино). Православный историко-краеведческий альманах. Вып. 1(6). М., 2001. С. 87-98.

12. Лобанов М. Элегия при гробе князя Смоленского // Сын Отечества. 1816. № 15. С. 106.

13. Пушкин А. С. Полное собрание сочинений: в 10 т. Т. 1. Л.: Наука, 1977. 480 с.

14. Раевский В. Прощание воина с милой // Сын Отечества. 1816. Ч. 4. С. 89.

15. Свиньин П. Письмо к брату из Хотина // Сын Отечества. 1916. № 29. С. 142.

16. Срезневский И. Благодарение Всевышнему, даровавшему победу на всеобщего врага // Украинский вестник. 1816. Ч. 2. Апрель. Харьков. С. 74, 75.

17. Ячменихин К. М. Алексей Андреевич Аракчеев. Российские консерваторы. M., 1997. C. 40. 


\section{References}

1. Avramov Matf<ei>. Glas Evropy pri verolomnom vstuplenii na berega Frantsii vraga vsemirnyia $i$ vtrokratnom pokhishchenii ee prestola kliatvoprestupnoi derzost'iu $v 1815 \mathrm{~g}$. [The voice of Europe during the treacherous entry of the enemy of France on the shores of France and the abduction of her throne three times by an oath of insolence in 1815]. Moscow, Universitet. tip. Publ, 1815. 50 p. (In Russ.)

2. Batiushkov K. N. Moi genii [My genius]. Batiushkov K. N. Opyty v stikhakh i proze [Experience in poetry and prose]. Moscow, Nauka Publ, 1977. 608 p. (In Russ.)

3. Vigel' F. F. Zapiski; red. i vstupitel'naia st. S. Ia. Shtraikha [Notes; ed. and introductory article S. Ya. Streich]. Moscow, Krug Publ, 1928. 387 p. (In Russ.)

4. Viazemskii P. A. Ital'iantsu, vozvrashchaiushchemusia iz Rossii // Sobranie obraztsovykh russkikh sochinenii i perevodov v stikhakh, izdannye Obshchestvom liubitelei otechestvennoi slovesnosti. Chast' chetvertaia [The Italian returning from Russia. Collection of exemplary Russian works and translations in verse, published by the Society of lovers of Russian literature. Part four]. St. Petersburg, 1816. (In Russ.)

5. Glinka F. N. Stikhi na 23 noiabria [Poems for November 23]. Syn Otechestva [Son of the Fatherland]. 1817. № 48. pp. 117-118. (In Russ.)

6. Dolgorukov I. M. Bytie serdtsa moego, ili Stikhotvoreniia kniazia Ivana Mikhailovicha Dolgorukago: $v 4 \mathrm{ch}$ [Genesis of my heart, or Poem by Prince Ivan Mikhailovich Dolgorukago: at 4 part]. Moscow, Universit. tip Publ., 1817-1818. Ch. 1. 241 p. (In Russ.)

7. Zhukovskii V. A. Sobr. soch.: v 4 t. [Coll. Works in 4 vols.] Moscow, Leningrad, Goslitizdat Publ, 1959-1960. Vol. 1. 480 p. (In Russ.)

8. Zabelin I. E. Dnevniki. Zapisnye knizhki [Diaries. Notebooks]. Moscow, Izd-vo im. Sabashnikovykh Publ, 2001. 383 p. (In Russ.)

9. Katenin P. A. Otechestvo nashe stradaet [Our fatherland is suffering]. URL: http:// stih.su/otechestvo-nashe-stradaet (access date: 23.07.2019). (In Russ.)

10. Krylov I. A. Basni: $v 9$ kn. [Fables in 9 books]. Moscow, Akad. Nauk Pudl, 1956. 635 p. (In Russ.)

11. Kubenskii A. (Rachinskii A. V.) Imperator Aleksandr I - pobeditel' v pervoi global'noi voine [Emperor Alexander I - winner in the first global war] Shcherbatovo (Mar'ino). Pravoslavnyi istoriko-kraevedcheskii al'manakh [Shcherbatovo (Maryino). Orthodox historical and local history almanac] .Vol. 1(6). Moscow, 2001. pp. 87-98. (In Russ.)

12. Lobanov M. Elegiia pri grobe kniazia Smolenskogo [Elegy at the tomb of Prince Smolensky]. Syn Otechestva [Son of the Fatherland]. 1816. № 15. pp. 106 (In Russ.)

13. Pushkin A. S. Polnoe sobranie sochinenii: v 10 t. [Complete Works: in 10 vols.] Vol. 1. Leningrad: Nauka Publ, 1977. 480 p. (In Russ.)

14. Raevskii V. Proshchanie voina s miloi [Farewell of a warrior with a sweetheart]. Syn Otechestva [Son of the Fatherland]. 1816. Part. 4. P. 89. (In Russ.)

15. Svin'in P. Pis'mo k bratu iz Khotina [Letter to brother from Khotyn]. Syn Otechestva [Son of the Fatherland]. 1916. № 29. P. 142. (In Russ.)

16. Sreznevskii I. Blagodarenie Vsevyshnemu, darovavshemu pobedu na vseobshchego vraga [Thanksgiving to the Almighty, who granted victory to the universal enemy]. Ukrainskii vestnik [Ukrainian Herald]. 1816. Ch 2. Aprel'. Khar'kov. P. 74, 75. (In Russ.)

17. Iachmenikhin K. M. Aleksei Andreevich Arakcheev. Rossiiskie conservatory [Alexey Andreevich Arakcheev. Russian conservatives]. Moscow, 1997. P. 40. (In Russ.) 


\section{Славянофил-государственник. Н. В. Гоголь в движениях эпохи}

Аннотация: В статье впервые на основании многочисленных источников предложено понимание общественно-политической позиции Гоголя как славянофила-государственника. Будучи неизменным сторонником единства славян, Гоголь придерживался глубоко «охранительных» взглядов по отношению к русской государственности. Во главу угла он ставил интересы России как уникального государства единственного славянского народа, сохранившего в истории свою независимость и самобытность. Единомышленниками Гоголя в таком понимании славянского вопроса были Н. М. Карамзин, С. С. Уваров и, отчасти, старейшие представители славянофильского лагеря, близкие друзья писателя М. П. Погодин и С. П. Шевырев, в свою очередь зарекомендовавшие себя в истории общественных течений как мыслители-государственники. Как убежденный славянофил Гоголь одновременно критически относился к оппозиционным взглядам своих приятелей, московских славянофилов К. С. Аксакова и И. В. Киреевского, к сепаратистским воззрениям своего земляка, слависта О. М. Бодянского, к негативно настроенным по отношению к дому Романовых польским славянофилам во главе с А. Мицкевичем, и позиции отечественных радикалов-западников В. Г. Белинского и А. И. Герцена. Делается вывод, что Гоголь стоял определенно выше многих представителей как западнического, так и славянофильского направлений, ибо по целому ряду вопросов превосходил не только далеких от него западников, но и гораздо более близких ему «восточников», которые тоже не достигали масштабности и объективности гоголевского художнического видения.

Ключевые слова: Гоголь, биография, творчество, интерпретация, славянофилы, западники, радикализм, консерватизм, монархизм, патриотизм, духовное наследие

Информация об авторе: Виноградов Игорь Алексеевич, ORCID 0000-0002-91514554 - доктор филологических наук, главный научный сотрудник, Институт мировой литературы им. А. М. Горького Российской академии наук, ул. Поварская, д. 25a, 121069 , г. Москва, Россия

E-mail: info@imli.ru

Дата поступления статьи в редакиию: 05.09.2019

Дата публикации статьи: 10.12.2019

Для цитирования: Виноградов И. А. Славянофил-государственник. Н. В. Гоголь в движениях эпохи // Два века русской классики. 2019. Т. 1. № 2. С. 36-61. DOI 10.22455/2686-7494-2019-1-2-36-61 


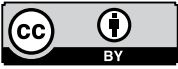

This is an open access article distributed under the Creative

Commons Attribution 4.0

International (CC BY 4.0)

\title{
(c) 2019. Igor A. Vinogradov \\ Moscow, Russia
}

\section{Slavophil-statesmen. N. V. Gogol in the movements of the epoch}

\begin{abstract}
In the article for the first time, on the basis of numerous sources, an understanding of the socio-political position of Gogol as a Slavophile state figure is proposed. Being a constant supporter of the unity of the Slavs, Gogol at the same time adhered to deeply "protective" views in relation to Russian statehood. At the forefront of Slavophilism, he put the interests of Russia as a unique state of the only Slavic people who retained their independence and identity in history. N. M. Karamzin, S. S. Uvarov and, partly, the oldest representatives of the Slavophile camp, close friends of the writer M. P. Pogodin and S. P. Shevyrev, in their turn, recommended themselves in the history of social currents as thinkers-statesmen. As a convinced Slavophile, Gogol at the same time was critical to the opposition views of his friends, the Moscow Slavophiles K. S. Aksakov and I. V. Kireevsky, the separatist views of his fellow countryman, the Slavist O. M. Bodyansky. Gogol was also critical to the negative attitude towards the Romanov's house of Polish Slavophiles led by A. Mickiewicz, and - to an even greater extent - to the position of the domestic radicals-Westerners V. G. Belinsky and A. I. Herzen. To be concluded, Gogol was definitely superior than both the Westernist and many representatives of the Slavophilist movement, because on a number of issues he was superior not only to the Westernists who were far from him, but also to the "Orientalists" who also could not reach the scale and the objectivity of Gogol's artistic vision.
\end{abstract}

Keywords: Gogol, biography, creativity, interpretation, Slavophiles, Westerners, radicalism, conservatism, monarchism, patriotism, spiritual heritage.

Information about the author: Igor A. Vinogradov, ORCID 0000-0002-9151-4554, DSc in Philology, Chief Researcher, A.M. Gorky institute of World Literature of the Russian Academy of Sciences, Povarskaya 25a, 121069, Moscow, Russia

E-mail: info@imli.ru

Received: September 05, 2019

Published: December 10, 2019

For citation: Vinogradov I. A. Slavophil-statesmen. N. V. Gogol in the movements of the epoch. Two centuries of the Russian classics, 2019, vol. 1, № 2, pp. 36-61. (In Russ.) DOI 10.22455/2686-7494-2019-1-2-36-61 
В истории славянофильства и западничества особую проблему представляет определение места, которое занимал в противостоянии двух идеологий Н. В. Гоголь. Внятного ответа на этот вопрос до сих пор не существует. С одной стороны, бытует мнение об «изъятости» писателя из полемики славянофилов и западников, с другой, - предполагается, что Гоголь находился «между» двумя современными течениями ${ }^{1}$, пытаясь якобы примирить «достоинства» обоих направлений.

О примирении всех русских людей во Христе Гоголь, действительно, размышлял, начиная с самых ранних своих произведений. Однако это всегдашнее христианское стремление Гоголя не имеет ничего общего с старанием «приблизить» писателя, под этим предлогом, к западнической идеологии. Само формирование славянофильства и западничества было во многом обязано произведениям Гоголя - прежде всего выходу в свет повести «Тарас Бульба», восторженно встреченной не только С. П. Шевыревым и М. П. Погодиным, но и молодым В. Г. Белинским. Впоследствии эта повесть прямо способствовала становлению национального самосознания славянства ${ }^{2}$. (Надо сказать, что за изучение истории славян Гоголь принялся на несколько лет раньше А. С. Хомякова.) Не меньшее значение имела публикация первого тома «Мертвых душ», полемика о котором К. Аксакова и Белинского явилась первым публичным актом размежевания критиков двух лагерей. Ярко выраженный славянофильский, антизападнический характер носит итоговая книга Гоголя - «Выбранные места из переписки с друзьями», - что очень хорошо понял, сразу по ее выходе, Белинский, впавший по этому поводу в «негодование и бешенство» [Белинский: 340].

Среди многочисленных свидетельств, указывающих на то, что Гоголь принадлежит к кругу славянофилов, наиболее показательной

1 Расхожее мнение. См., к примеру: [Сакулин: 375].

2 См. [Виноградов, 2009: 494-495, 526-527, 554-556, 559-561, 569-574, 577, 580-581, 591-606]. 
является в «Переписке с друзьями» статья «Споры». Здесь Гоголь со всей определенностью утверждает, что правды, «разумеется», «больше» на стороне славянофилов, чем западников [Гоголь. Т. 6: 51-52]. По словам писателя, последние «давно бы готовы были <..> отступиться» от своих взглядов, но «упорствуют» - потому что «не желают уступить слишком раскозырявшейся» противоположной стороне [Гоголь. Т. 6: 51-52].

В еще одной статье «Выбранных мест...», «О лиризме наших поэтов», Гоголь также недвусмысленно выступает в защиту славянофилов, возражая против критического мнения о них своего друга, поэта В. А. Жуковского [Виноградов, 2018 (a): 259].

Весьма значимым в этом ряду является откровенное восторженное одобрение Гоголем антизападнического стихотворения Н. М. Языкова «К ненашим». «Сам Бог внушил тебе прекрасные и чудные стихи “К не нашим". - писал Гоголь Языкову. $-<\ldots>$ Они $<\ldots>$ сильней всего, что у нас было писано доселе на Руси» [Гоголь. Т. 13: 29]1․

Среди других свидетельств, проясняющих славянофильские взгляды Гоголя, следует указать на то, что в письме к С. Т. Аксакову Гоголь, работая над вторым томом «Мертвых душ», сообщал, что круг идей, занимающих славянофилов, волнует его не менее самого Константина Аксакова - старшего из аксаковских сыновей, «восточника» с наиболее радикальными взглядами (см.: [Гоголь. Т. 15: 88]).

Само по себе показательно то, что все друзья Гоголя были исключительно из славянофильского и консервативного лагеря. Западник П. В. Анненков, некоторое время живший с Гоголем в Риме, другом ему так и не стал. Гоголь относил Анненкова к «господам, до излишества живущим в Европе» [Гоголь. Т. 15: 443].

Между Гоголем и его друзьями-славянофилами возникали подчас и существенные разногласия по отдельным вопросам. Однако порождались они отнюдь не симпатиями Гоголя к западнической идеологии, а сугубой приверженностью писателя к традиционным взглядам - тем, что обсуждаемые проблемы он решал с духовной точки зрения. К примеру, значение для упрочения народного быта перевода В. А. Жуковского «Одиссеи» Гомера или такую же роль публикации «Домостроя» протопопа Сильвестра Гоголь ставил настолько высоко, что считал появление этих изданий делом куда более важным, чем отвлеченные

\footnotetext{
${ }^{1}$ См. также: [Гоголь. Т. 13: 30].
} 
рассуждения друзей о славянских началах. Аксаковы, как известно, весьма критично отнеслись к обеим этим книгам․

Определенно «правее» своих друзей-славянофилов Гоголь был и в собственно политических вопросах. Хорошо известно, что славянофильству была присуща изрядная доля оппозиционности. Примеры оппозиционности со стороны славянофилов, проявления их политического радикализма довольно многочисленны; эту отличительную черту они демонстрировали неоднократно ${ }^{2}$. В. Г. Белинский в письме к П. В. Анненкову 1848 г. замечал: «...Лучшие из славянофилов смотрят на народ совершенно так, как мой <..> друг <M. А. Бакунин>; они высосали эти понятия из социалистов, и в статьях своих цитируют Жоржа Занда и Луи Блана» [Белинскиц̆: 468]. Именно от своих приятелей-славянофилов Гоголь мог услышать доброжелательный отзыв о западнике А. И. Герцене. Об этом отзыве он упомянул в 1847 г. в письме к П. В. Анненкову (см.: [Гоголь. Т. 14: 439-440]). В свою очередь, Герцен в 1850 г. замечал: «...Социализм, который так решительно, так глубоко разделяет Европу на два враждебных лагеря, - разве не признан он славянофилами так же, как нами? Это мост, на котором мы можем подать друг другу руку» [Гериен: 248].

Брошюра Герцена «О развитии революционных идей в России», откуда взяты эти строки, была встречена Гоголем неодобрительно. В отличие от своих фрондирующих друзей «подать руку» западником на таком основании Гоголь не мог. Свое отношение к теории, способной, по мнению Герцена, объединить славянофилов и западников, Гоголь вполне обозначил в 1847 г. в неотправленном письме к Белинскому, говоря о «нынешних ком $<$ м $>$ унистах и социалистах, объясняющих, что Христос повелел отнимать имущества и грабить тех, которые нажили себе состояние» [Гоголь. Т. 14: 388].

Свидетельства об оппозиционности славянофильства весьма многочисленны. В конце 1845 г. Ю. Ф. Самарин не без иронии писал К. Аксакову об их общих московских беседах: «Мы вели такие разговоры, <..> что не идти на другой день на Петербург войною значит дать шаг назад и уронить себя в общем мнении» [Самарин: 152]. В начале апреля 1847 г. тот

1 См.: [Гоголь. Т. 13: 457]; [Виноградов, 2012: 588, 602-603, 607, 651, 798, 849, 913]; [Пирожкова: 633]; [Виноградов, 2018 (а): 383-384].

2 Подробнее об известной «оппозиционности» к существующему положению вещей не только «европистов», но и «восточников» см.: [Виноградов, 2017 (в)]. 
же Самарин сообщал А. С. Хомякову: «Я узнал, что дано весьма секретное приказание схватить Чижова, Савича и Кулиша, как скоро они переедут нашу границу, запечатать всех их бумаги и препроводить их под надзором жандарма в Петербург. <...> ...Весьма может быть, что доберутся и до нас. $<\ldots>$...Как бы предупредить Чижова и прочих» [Самарин: 422].

Спровоцированные тогда деятельностью киевского Украино-славянского общества гонения на славянофилов затронули Ф. В. Чижова, А. С. Хомякова, И. С. Аксакова и самого Самарина. Упомянутые Самариным в письме Н. И. Савич и П. А. Кулиш, вместе с Т. Г. Шевченко и др. состояли в указанном обществе, объединявшем сепаратистски настроенных по отношению к российской государственности украинских славянофилов (организаторы называли своей кружок Обществом Святых Кирилла и Мефодия). В частности, в 1847 г., будучи за границей, Савич передал главе польских славянофилов, А. Мицкевичу, поэму Шевченко «Кавказ». Оправдывая свой политический сепаратизм идеей единства славян, члены Украино-славянского общества являлись в этом отношении прямыми наследниками пропольской оппозиционной ложи «Соединенных славян» (действовала в Киеве в 1818-1822 гг.) и аналогичного преддекабристского «Общества соединенных славян» (1823-1825 гг.). Подготовку «возмущения, гибельного для России» под благовидным предлогом сочувствия к западным славянам Император Николай I называл в 1849 г. смешением «преступного с святым» [Аксаков И. С.: 502].

Отдельные расхождения Гоголя со славянофилами порой проявлялись даже на бытовом уровне. В 1849 г. Гоголь, вернувшийся в 1848 г. из-за границы, не был приглашен на именины К. С. Аксакова 21 мая, а двумя неделями ранее сам К. С. Аксаков не явился на именины Гоголя 9 мая. В этот период Ольга Семеновна Аксакова неоднократно жаловалась сыну Ивану, что Гоголь постоянно говорит Константину «очень резкие вещи» - даже «оскорбляет» его (см.: [Гоголь в неизданной переписке...: 715-716]). Тогда же сам Константин Аксаков сообщал брату: «...Столкновения мои с Гоголем часто неприятны; в его словах звучит часто ко мне недоброжелательство и оскорбительный тон» [Гоголь в неизданной переписке...: 715].

Суровое отношение Гоголя к К. С. Аксакову носило, судя по всему, принципиальный характер. Оно было связано с их острым спором о значении для России единодержавия. В «монархическом», чрезвычайно важном для Гоголя вопросе Аксаковы выступали единым фронтом 
против писателя - вполне «в ногу» с своим давним знакомым Белинским. Примечателен вывод, сделанный из споров с Аксаковыми А. О. Смирновой, в письме к Гоголю 1847 г.: «Ненависть к власти, к общественным привилегиям, к высокому рождению и богатству - такова-то отвлеченная страсть к идеальному русскому, таящемуся в бороде, - вот начало этих господ» [Гоголь. Т. 14: 165].

Будучи гораздо более основательным, чем его друзья, последователем славянофильского учения, Гоголь хорошо разбирался в разнообразных течениях этого общественного движения, отчасти нами сегодня подзабытых (см.: [Виноградов, 2017 (a)]; [Виноградов, 2017 (б)]). Наибольший контраст гоголевским взглядам представляло славянофильство польских националистов во главе с Мицкевичем. С этой ветвью славянофильства едва не смыкалось в негативном отношении к России отечественное западничество. Между тем сами славянофилы, в том числе московские, ощущали себя во многом принадлежащими к «единому» полю славянофильства. В отличие от этого сомнительного «единодушия», взгляды Гоголя как убежденного славянофила отличались не только от воззрений западников, но и от позиции более близких ему по духу современников. Не только над западным польским славянофильством, но и над сепаратистки ориентированным украинским славянофильством земляка О. М. Бодянского ${ }^{1}$, и над оп-

1 Как указывал позднее И. И. Срезневский, «выбор задачи» для защищенной в 1837 г. в Московском университете диссертации О. М. Бодянского «О народной поэзии Славянских племен» «не был решением только частного пристрастия к ней самого Бодянского: он был первым литературным последствием одного из нововведений Университетского устава 1835 года, которым в числе кафедр историко-филологического факультета дало место кафедре истории и литературы Славянских наречий» [Срезневский: 32]. Срезневский продолжал: «Почти непосредственно за преобразованием Московского университета на кафедру эту вошел <..> М. Т. Каченовский (который был перемещен сюда, за свои резко “скептические” взгляды по поводу отечественного прошлого, с кафедры русской истории - которую вместо него возглавил М. П. Погодин. - И. В.).. <..> На виду у Каченовского как будущий помощник его по кафедре был Бодянский, ученик им любимый и по познаниям, и по трудолюбию, и как земляк. Каченовский стал поддерживать Бодянского в занятиях Славянскими наречиями и был главным виновником выбора предмета для диссертации - если не в частности, то по крайней мере вообще» [Срезневский: 32-33]. Таким образом, вопреки намерениям Уварова, его начинание - учреждение в университетах славянских кафедр, 
позиционной, критически настроенной к «дому Романовых» частью московского славянофильства, прежде всего, Аксаковыми, - над всеми этими друзьями и знакомыми из круга славянофилов Гоголь возвышается как последовательный славянофил-«государственник»‥ Во главу угла славянофильства Гоголь ставил интересы России как уникального государства единственного славянского народа, сохранившего в истории свою независимость и самобытность. Именно этим объясняется глубоко «охранительное» отношение Гоголя к русской государственности. В таком понимании значения России в славянском мире Гоголь был отнюдь не одинок. Среди его единомышленников можно назвать Н. М. Карамзина, С. С. Уварова (см.: [Виноградов, 2018 (a): 385]), М. П. Погодина, С. П. Шевырева (старейших представителей славянофильского движения, по праву также считающихся мыслителями-государственниками), сербского святителя Петра Цетинского (Негоша, 1748-1830). Последний говорил: «...Радость и счастье всего славяно-иллирийского народа зависят от процветания и славы высокославных россов, правление которых для расширит Бог во все концы

призванное способствовать изучению славянства, с самого начала стало приобретать сепаратистский, оппозиционный характер.

Радикализм гоголевских земляков Каченовского и Бодянского в свою очередь имеет много общего с радикальными негативными взглядами на русскую классику украинофильствующего издателя журнала «Маяк» С. О. Бурачка. В отличие от Гоголя, Бодянский и Бурачек были безусловными почитателями творчества Т. Г. Шевченко (с которым были лично знакомы). Известно, что в 1847 г. Шевченко за свою русофобию и негативное отношение к русской государственности был официально осужден. Гоголь, как и в случае с Бодянским, критически относился к нигилистическим взглядам Шевченко и Бурачка. По поводу Бурачка писатель, в частности, замечал: «Односторонние люди и притом фанатики - язва для общества... <..> У них нет никакого смиренья христианского и сомненья в себе; они уверены, что весь свет врет и одни они только говорят правду» [Гоголь. Т. 6: 63].

1 Речь идет не о том, чтобы дать Гоголю новое определение (в данном случае определение славянофила-государственника), но о том, чтобы через это обозначить некие закономерности гоголевского мировоззрения. Подобно тому, как в споре романтизма и классицизма Гоголь как гений преодолевает узость современной ему полемики и возвышается над современниками в качестве самобытного писателя-неоклассика, так же в общественно-политических движениях времени он превосходит своих наиболее глубоких и проницательных современников оригинальной позицией славянофила-государственника. 
вселенной» [Петр Цетинский: 325-326]. «Кто против них, тот против и нас», - отвечал святитель наполеоновскому генералу Мармону по поводу отношения сербов к русским [Лавелэ: 52].

В изучении вопроса о месте Гоголя в полемике славянофилов и западников особый интерес представляет письмо, включенное писателем в «Выбранные места из переписки с друзьями» с полемическим названием «Близорукому приятелю». Славянофильский пафос этой статьи очевиден. В статье «Споры» Гоголь замечал о западниках, что, в отличие от славянофилов, они рассуждают о России, подойдя «слишком близко к строению» [Гоголь. Т. 6: 51]. В точном соответствии с этой характеристикой в статье «Близорукому приятелю» Гоголь критикует «взгляд современной близорукости», - прямо подразумевая под этим западничество [Гоголь. Т. 6: 134].

При всем этом надо, тем не менее, иметь в виду, что в итоговой книге Гоголя, наряду с преобладающей антизападнической направленностью, есть и вполне определенная критика в адрес славянофилов. Так, в статье «О том, что такое слово» заключается, как известно, весьма нелицеприятное обличение литературной и научной деятельности одного из видных представителей славянофильского лагеря Погодина. В то же время, обращая внимание на эту статью, важно не упустить весьма существенную особенность гоголевской критики Погодина. Если в отношении к западничеству Гоголь не разделяет самих идей «европистов» - взглядов, почерпнутых из «иностранных книг» и «английских журналов» (согласно строкам статьи «Близорукому приятелю» - [Гоголь. Т. 6: 134]), то применительно к славянофильству его позиция принципиально иная.

Обращаясь к «близорукому приятелю», Гоголь критикует не столько представителей западничества, но главным образом сами западные воззрения, которыми заражен его корреспондент. Напротив, в статье с критикой Погодина, «О том, что такое слово», славянофильские взгляды Гоголь защищает - обличая их недостойного, «недозревшего» до них носителя - своего друга. В отличие от «близоруких» представлений западников, славянофильские и верноподданнические воззрения настолько дороги Гоголю, что выговаривает он приятелю - своему единомышленнику - вовсе не за эти общие, одинаково разделяемые ими взгляды, но обличает его за их недопустимую профанацию. По гоголевской оценке, Погодин как профессор университета и как издатель славянофильского журнала «Москвитянин» своей торопливостью, «неряшеством и 
неопрятностью» [Гоголь. Т. 6: 21] компрометирует важнейшее для России, для всех русских людей дело - так же, как повредил этому патриотическому делу упоминаемый в той же статье Г. Р. Державин, наиболее почитаемыцй, с детства любимый Гоголем поэт, который должен был, по гоголевской оценке, ради этих самых дорогих, заветных идей, «сжечь по крайней мере целую половину од своих»: «Сколько усумнилось в искренности его чувств потому только, что нашли их во многих местах выраженными слабо и бездушно...» [Гоголь. Т. 6: 20].

Обличение Погодина, мотивированное заботой об общем деле, стремлением уберечь это дело от профанации ${ }^{1}-$ не единственное критическое выступление Гоголя, направленное на конкретных представителей славянофильства - своих друзей. Таким же стремлением продиктовано сразу несколько гоголевских обличений - по разным поводам - в адрес славянофила К. С. Аксакова. Об одном из них, по поводу «дома Романовых», уже говорилось. Обратимся к другим.

Когда Аксаков, ратуя за народность, стал ходить в русском кафтане и отпустил бороду - не без вызова самим правительственным постановлениям ${ }^{2}$, - то, по оценке Гоголя, этим поступком он даже не скомпрометировал себя, но, употребляя собственное выражение писателя, «просто охаял», выставил на смех важнейшее начинание [Гоголь. Т. 13: 388].

1 Возможно, обличение Погодина в «Выбранных местах из переписки с друзьями» объясняется, помимо прочего, и нежеланием Гоголя, чтобы тот высказал книге в печати свое одобрение. По замыслу Гоголя, «Переписка с друзьями» была адресована людям самых разных взглядов и направлена на объединение противоборствующих в России партий (см. [Виноградов, 2017 (2): Т. 4: 454-457]), тогда как предсказуемо восторженный отклик на его книгу Погодина в журнале «Москвитянин» сделал бы ее знаменем лишь одной, хотя и наиболее близкой самому автору партии, и тем самым оттолкнул бы от книги, сформировал предвзятое к ней отношение читателей других взглядов, прежде всего, западников, стоящих, по словам Гоголя в письме к С. П. Шевыреву от 11 февраля (н. ст.) 1847 г., «на низшей перед нами ступеньке воспитанья»[Гоголь. Т. 14: 81]. Предполагаемое выступление Погодина в поддержку «Выбранных мест...» могло бы стать неуместной услугой Гоголю - чего тот, вероятно, и опасался от «медвежьей натуры» Погодина (выражение из письма Гоголя к Н. М. Языкову от 12 ноября (н. ст.) 1844 г. [Гоголь. Т. 12: 494]).

${ }^{2}$ Существовал указ от 2 апреля 1837 г. «О воспрещении гражданским чиновникам носить усы и бороду» (Полн. собр. законов Российской Империи. Собр. 2-е. СПб., 1838. Т. 12. Отд. 1. С. 206). 
Эта критика Аксакова отнюдь не означала осуждения Гоголем самих национальных традиций вплоть до внешнего облика. Он писал Аксакову: «Я сам питаю отвращение к нашему обезьянскому европейскому наряду $<\ldots>$; но $<\ldots>$ у нас $<\ldots>$ царь - глава, и только то, что передастся через него $<\ldots>$ облекается в законность» [Гоголь. Т. 13: 216-217]. Судя по всему, писатель помнил слова св. пророка Софонии: «И будет, в день жертвы Господни, и отмщу на князи и на дом царский, и на вся оболченныя во одеяния чуждая...» (гл. 1, ст. 8). Поэтому призывая приятеля временно воздержаться от «ношения бороды, русского кафтана» [Гоголь. Т. 13: 216], Гоголь по-прежнему выказывал себя как последовательный славянофил«государственник». Как и в других случаях, особенность позиции писателя заключалось в том, что, разделяя основные положения славянофильства, он считал некоторые из славянофильских начинаний преждевременными.

За то же самое - за преждевременность и профанацию важного начинания - Гоголь критиковал К. С. Аксакова и в связи с проповедуемыми последним взглядами о значении Москвы. По этому поводу Гоголь в письме к Аксаковым замечал: «Чувствуете ли вы страшную истину сих слов: Не приемли имени Господа Бога твоего всуе?» [Гоголь. T. 12: 157]. В статье "О том, что такое слово», с критикой Погодина, Гоголь добавлял: «Чем истины выше, тем нужно быть осторожнее с ними... <...> Не столько зла произвели сами безбожники, сколько <...> неприготовленные проповедатели Бога, дерзавшие произносить имя Его неосвященными устами» [Гоголь. Т. 6: 21].

Епископ Варнава (Беляев), говоря об идейных основах славянофильского учения, указывал: «Конечно, для знакомого с аскетической святоотеческой литературой учение славянофилов не представляет чего-нибудь нового, но для внешнего мира оно, безусловно, новая и доброкачественная мысль. Уже и сейчас, как она есть, эта школа достойна составить важную главу в истории русской философии, а если бы была поддержана и развита, то, возможно, произвела бы в ней настоящий переворот» [Варнава, епископ: 247].

Однако эта характеристика славянофильства отражает лишь одну, самую позитивную из его сторон. Именно эта сторона была близка Гоголю, так что в этом отношении его с полным правом можно назвать славянофилом. Но наряду с позитивным началом, в славянофильском учении были (увы!) элементы иного характера, прямо роднящие его с 
западничеством. Прежде всего, это касается истоков этого общественного течения.

И. В. Киреевский, прошедший в свое время западную выучку, слушавший в Германии лекции Шеллинга и Гегеля, в 1856 г., незадолго до смерти указывал: «Если бы не узнала Россия Шеллинга и Гегеля, то как уничтожилось бы господство Вольтера и энциклопедистов над русскою образованностью?» [Киреевский, 1857: 7]. Судя по всему, это самооправдание Киреевский почерпнул у самого А. С. Пушкина. В одной из глав незавершенного очерка о Радищеве, впервые напечатанного в отрывках в 1841 г., поэт замечал: «Философия Немецкая, которая нашла в Москве, может быть, слишком много молодых последователей, кажется, начинает уступать духу более практическому. Тем не менее, влияние ее было благотворно: она спасла нашу молодежь от холодного скептицизма Французской философии...» [Пушкин: 18].

С этими важными пушкинскими размышлениями, затрагивающими самые истоки славянофильского «любомудрия», Гоголь, как выясняется, познакомился еще в 1836 г., прочтя их в рукописи. Уже тогда Гоголь, имея в виду замечание поэта о далекой от «практического» духа немецкой философии, в одной из рецензий, написанных для пушкинского «Современника», выступил с резкой критикой отвлеченных «рассуждений и трактатов», из которых «все практическое», «взятое из жизни» изгонялось, ибо считалось «пустым и недостойным» [Гоголь. T. 7: 494] $]^{1}$. Еще в первой половине 1830-х гг. оторванную от жизни

1 Критикуя схоластические сочинения, Гоголь отмечал, что несмотря на мнимую «питательность» этих книг, нравственность их читателей была «не очень чиста» [Гоголь. Т. 7: 494]. Наряду с отвлеченными «нравственными» произведениями появилась тогда масса откровенно безнравственных [Гоголь. Т. 7: 494]. К тому же туманная схоластика стала главной причиной «малого распространения охоты к чтению в нашем обществе» [Гоголь. Т. 7: 494]. Этот неутешительный вывод Гоголь подводил как для предшествующего века, так и для своего времени: «Такой раздор теории с практикою был повсеместен в конце 18 столетия. В 19 столетии масонские и другие секты, отвлеченный мистицизм поддержали существование подобных философских сочинений, рассуждений, увещаний и трактатов, хотя облеченных уже в другие формы» [Гоголь. Т. 7: 494]. Необходимость появления новых форм, в которые «облеклись», благодаря усилиям популяризаторов, новейшие трактаты, Гоголь объяснял самим характером немецкой философии: «Когда Кант, Шеллинг, Гегель, Окен < .. > обработывали науку, <..> их мнения распространялись только в кругу небольшом 
их слушателей...» [Гоголь. Т. 7: 494]. Но и обновленный «другими», более приемлемыми формами изложения «схолацизм», по наблюдениям Гоголя, в существе своем не изменился. Несмотря на то, что последователи немецких философов, «среднего класса люди», «без орлиной мысли и таланта», изложили их абстрактные рассуждения «общеупотребительным языком», - так что «приученные мистицизмом читатели брались охотно за эти книги» [Гоголь. Т. 7: 494], - тем не менее, удаленная от практики мысль осталась по-прежнему бесплодной. Яркой противоположностью тщетной схоластической философии, спасительным выходом из тупика, является, по убеждению Гоголя, «высший» род словесности [Гоголь. Т. 6: $324]$ - подлинная, связанная с жизнью, проникнутая глубокой мыслью поэзия. В своей рецензии Гоголь, обращаясь еще раз к словам Пушкина о замене немецкой философии «духом более практическим», писал: «В наш век почти общим сочувствием была признана необходимость воплощения всякой мысли практически. <...> ...Дела более значат, нежели слова. Живой пример сильнее рассуждения, и никогда мысль не кажется нам так высока, <..> когда разрешается пред нами живым, знакомым миром, когда она, можно сказать, читается духовными нашими глазами из целого создания поэта. Божественный Учитель и Спаситель наш первый открыл эту высокую тайну, облекши святые божест<венные> мысли Свои в притчи, которые слушали и понимали тысячи народов» [Гоголь. Т. 7: 494-496]. - Можно заметить, что логика гоголевской рецензии, предназначавшейся для пушкинского «Современника», сама ее композиция, строится в точном соответствии с словами апостола: «Братие, блюдитеся, да никтоже вас будет прельщая философиею <...>, по стихиям мира, а не по Христе» (Кол. 2, 8). Еще до редакторства в «Современнике» Гоголь в статье «Ал-Мамун» (1834) указывал на пагубность отвлеченной схоластики - лишь маскирующейся «христианскими формами», но на деле несущей в себе вполне языческие начала, «начала политеизма», - на обольстительную «кучу слов», «дерзко обезобразивших идеи христианства» [Гоголь. Т. 7: 350-351]. Позднее, в «Авторской исповеди», Гоголь писал: «Жизнь я преследовал в ее действительности, а не в мечтах воображения, и пришел к Тому, Кто есть источник жизни» [Гоголь. Т. 6: 228].

«Итак, - заключал Гоголь в рецензии, предназначавшейся на пушкинского «Современника», - мы, сделавши такие великие тысячелетние обходы, наконец возвращаемся к той истине, которая была сказана еще в глубине младенческих сердец наших. И вот уже история показывает умам соединение с философией и образует великое здание. И вот уже везде, во всех нынешних попытках романов и повестей, видно стремление осуществить, окрылить или доказать какую-нибудь мысль, и только посредственность бывает виною, что изысканная, неправильная мысль иногда предпочитается глубокой и простой» [Гоголь. Т. 6: 495]. Вскоре, в «Мертвых душах», Гоголь прямо повторил эти размышления: «Какие 
отвлеченность, «изысканность» схоластики Гоголь определял, вслед за Пушкиным, как характерный признак ограниченности и «посредственности» ${ }^{1}$. В самом начале сотрудничества Гоголя с московскими славянофилами, наряду с единодушием в общем понимании главных положений славянофильского учения, созревала гоголевская критика тех черт славянофильства, которые оказывались несовместимы с взглядами православного мыслителя.

В 1902 г., подразумевая цитированные слова Киреевского о «господстве Вольтера» и об «уничтожении» этого «господства» Шеллингом и Гегелем, известный впоследствии патролог Н. И. Сагарда так объяснял связь славянофильства с немецкой философией: «Кумир, воздвигнутый Европой в лице Вольтера и французских энциклопедистов, был ниспровергнут вместе с французской революцией; но вскоре <... на вновь воздвигнутом пьедестале <...> Шеллинг и Гегель сменили Вольтера. Русская передовая молодежь, привыкшая зорко следить за тем, что происходило у наших западных соседей, не замедлила ознакомиться с этими метафизическими системами... <..> Кто не знаком был с немецкой философией, <..> тот не признавался образованным человеком... <..> ...Особенно замечателен кружок, <..> собиравшийся в $<\ldots>$ доме А. П. Елагиной. <..> Наряду с <..> братьями Киреевскими, Хомяковым, К. Аксаковым, Ю. Самариным, Валуевым, И. Аксаковым и др. здесь можно было встретить и позднейших их антагонистов $<\ldots>$ Герцена, Грановского, Белинского и др. <..> Содержание споров вращалось на том, что было тогда господствующим интересом нового литературного поколения, - это была немецкая философия... <..> По вопросу о национальной самобытности <..> особенно выдвинута была философия Шеллинга и Гегеля» [Сагарда: 870-872].

Именно в критическом отношении к западной схоластике, «родной» для большинства славянофилов, и заключается, наряду с отвержением оппозиционности и осуждением скороспелости их начинаний, прин-

искривленные, <...> заносящие далеко в сторону дороги избирало человечество, стремясь достигнуть вечной истины, тогда как перед ним весь был открыт прямой путь... <...> Поди ты сладь с человеком! <..> пропустит мимо создание поэта, ясное как день, $<\ldots>$ а бросится именно на то, где какой-нибудь удалец напутает, наплетет, изломает, выворотит природу...» [Гоголь. Т. 5: 203, 200].

1 О гоголевской критике схоластического мышления см. подробнее: [Виноградов, 2016 (6)]. 
ципиальное размежевание Гоголя с его друзьями. Весьма характерно в этой связи то, что, когда весной 1840 г. Гоголь оказался непосредственно в кружке московских славянофилов, то именно Иван Киреевский не нашел с ним общего языка. Е. М. Хомякова, передавая тогда брату Н. М. Языкову критический отзыв Киреевского о Гоголе, замечала: «У них кто не кричит, тот и глуп» [Хомяков: 106].

Известно, что Гоголь предпочитал выражать свою точку зрения в многозначных художественных образах, а не в схоластических диспутах и «словопрениях» (2 Тим. 2, 14). В статье «Споры» он замечал: «Поверь, уже так заведено и нужно, чтобы передовые крикуны вдоволь выкричались $\langle\ldots>$, дабы умные могли $<\ldots>$ надуматься вдоволь» [Гоголь. Т. 6: 53]. Для «передового крикуна» Киреевского эта принципиальная особенность Гоголя осталась не понятой. Но о гоголевском критическом отношении к схоластическим и радикальным чертам славянофильства можно определенно судить по взаимоотношениям писателя с тем же К. С. Аксаковым, до которого Гоголь попытался донести свою позицию, видимо, потому, что находился с ним в более близких отношениях.

На «немецкое» философствование К. С. Аксакова, по-прежнему объединявшее его (до определенной степени) с бывшим московским приятелем Белинским, Гоголь указывал не раз. Гоголю было хорошо известно, с какими восторженными впечатлениями вернулся К. С. Аксаков в конце октября 1838 г. в Россию после нескольких месяцев пребывания в Германии и Швейцарии.

В июле 1838 г. Аксаков писал родным из Дрездена: «Дрезден, Дрезден! <..> Здесь только явилась мне дорогая моя Германия <...> Я русский, $\langle\ldots>$ но $\langle\ldots>$ только в Германии (т. е. в просвещении ее) могу находить <...> полную отраду» [Аксаков К. С., 1898: 82-85]. Стоит сравнить с этими аксаковскими признаниями отзывы о своих заграничных вояжах других гоголевских друзей и знакомых. П. В. Киреевский в ноябре 1829 г. писал брату Ивану: «Только побывавши в Германии, вполне понимаешь великое значение Русского народа, свежесть и гибкость его способностей, его одушевленность» [Лясковский: 22-23]. Шевырев в 1832 г. писал из-за границы Погодину: «...Все убеждает меня, что наша пора пришла, и двинь нас царь, мы будем первыми. <...> ...Радуюсь, что я Русский. Возвращаюсь более Русским, нежели чем поехал» [Мартынов: 110, 260]. Граф И. М. Виельгорский, совершавший заграничное путешествие в свите Наследника, в 1838 г. сообщал сестре из Эмса: 
«Я благодарю Бога, что я русский; <...> ...Россия молода, народ свеж, и ее ожидают великие судьбы. Я с каждым днем становлюсь более и более русским в душе...» [Розанов: 301-302].

Были, конечно, и те, в ком заграница оставляла иные следы. О таких святитель Игнатий (Брянчанинов) в 1859 г. замечал: «Я видел в Петербурге купцов, погостивших в Европе, и подивился тому удалению, той дикости, которые они начали являть к Церкви и духовенству. Видел там детей священнических, образованных по-европейски: то же самое!» [Игнатий Брянчанинов: 368].

О том, какова могла быть или даже была, но осталась без подробных свидетельств, полемика Гоголя с К. С. Аксаковым по поводу увлечения последнего Германией, можно судить по многолетнему, длившемуся с 1838 г. по 1842 г., спору писателя по этому же вопросу со своей бывшей ученицей М. П. Балабиной (см.: [Виноградов, 2017 (2): Т. 2: 575-576]).

Увлечение своего друга К. С. Аксакова «отрадным» немецким «просвещением» не могло не насторожить Гоголя. Кроме Балабиной перед его глазами был еще один разительный пример, когда влияние новейшей европейской философии отрицательно сказалось на взглядах близкого ему человека. Гоголь не мог не поразиться, сколько невразумительного, подчас еретического осталось в размышлениях его друга художника А. А. Иванова ${ }^{1}$, создателя знаменитой картины «Явление Мессии» (1832-1857), после его знакомства и близкого общения в 1832-1833 гг. с московским «любомудром» Н. М. Рожалиным, приехавшим в Рим из Мюнхена после слушания там вместе с И. В. Киреевским лекций немецких профессоров.

Страстное увлечение К. С. Аксакова и других московских славянофилов немецкой философией, являющее собой наглядный феномен западничества в славянофильстве, было вполне очевидно для окружающих и в те же годы было отмечено не одним Гоголем. Так, даже о самом выдающемся и наиболее глубоко преданном вере и Церкви славянофиле, А. С. Хомякове, князь П. А. Вяземский в 1847 г. писал В. А. Жуковскому: «...Его народность и руссословие несколько отуманены немецким, или вообще нерусским направлением» [Гиллельсон, 1969: 296]. Другой современник, сенатор и литератор К. Н. Лебедев замечал: «Из сочинений его “Ермак” и “Дмитрий Самозванец” замечательны своею историческою неверностию, германской идеализацией. <..>

${ }^{1}$ См.: [Зуммер: 19-20], [Алленов: 150-151], [Виноградов, 2001: 9, 83, 88-100, 113, 115-116, 131-132, 135, 144]. 
Я видывался с ним в 1850 г. у А. Е. Шиповой и М. П. Погодина. Мне не понравился он безусловным порицанием Европейских заимствований и всех действий правительства, о которых он не имел даже приблизительно точных сведений» [Лебедев: 573].

Славянофил Чижов, человек религиозный, крайне возмущенный в 1836 г. запрещением Государем периодического издания «Русский сборник» (Император, как известно, написал тогда на представлении: «и без того много»), назвал Государя в своем дневнике «коронованным скотом» [Долдобанов, Сидоров: 850].

Вполне вероятно, что пастырская деятельность отца Матфея Константиновского среди старообрядцев Ржева тоже была близка Гоголю именно потому, что тот, в свою очередь, имел дело с людьми верующими, но настроенными против правительства. Известно, что старообрядцы внесли свой вклад в революцию 1917 г. Именно оттуда идет линия признания русского императора, Петра I, антихристом и свойственное для славянофильской критики обличение петровских реформ. Тема раскола, как известно, присутствует в «Мертвых душах».

Иван Киреевский даже в 1855 г., к тому времени уже прочно связавший свою жизнь с Оптиной Пустынью, принимавший участие в оптинских изданиях творений святых отцов, написавший подробное житие преподобного Паисия Величковского, опубликованное в 1844 г. в погодинском «Москвитянине» [Киреевский, 1844] $]^{1}$, - в письме к князю П. А. Вяземскому, говоря о покойном Императоре Николае I, «обличал» его вполне по-«герценовски»: «...Хвалить его <Государя > <...> за покровительство и сочувствие к просвещению и словесности - то же, что хвалить Сократа за правильный профиль. <..> Гоголю царь дал несколько денег на бедность, не зная хорошо, кто такой Гоголь, и не для него, а для тех, кто за него просили. Когда имя Гоголя и его громкое значение в нашей литературе сделались известными, то даже память о нем преследовалась, как вещь, враждебная правительству. Спросите об этом Ивана Тургенева и Ивана Аксакова» [Гиллельсон, 1966: 132].

Вопреки заявлениям Киреевского, сам Гоголь вряд ли согласился бы с такой интерпретацией отношений к нему монарха, - ни в изложении Киреевского или Аксакова ${ }^{2}$, ни, тем более, со слов западника Тургенева ${ }^{3}$.

\footnotetext{
1 Авторство И. В. Киреевского указано П. Н. Сакулиным [Сакулин: 393].

2 См.: [Виноградов, 1998]; [Виноградов, 2016 (а)].

${ }^{3}$ См.: [Виноградов, 2018 (б)].
} 
Становятся в этом свете понятными и упреки Константину Аксакову в склонении к «неметчине лукавой», которые адресовал ему друг Гоголя, поэт Николай Языков в послании «К молодому человеку» (1845): «Дай руку мне! Но ту же руку / Ты дружелюбно подаешь / Тому, кто гордую науку / И торжествующую ложь / Глубокомысленно становит / Превыше истины святой, / Тому, кто нашу Русь злословит / И ненавидит всей душой, / И кто неметчине лукавой / Передался. - И вслед за ней, / За госпожою величавой, / Идет блистательный лакей...». Это языковское стихотворение Гоголь оценил как впечатляющее, «нестерпимое количество света», поднесенное «к глазам» Аксакова [Гоголь. Т. 13: 85].

По поводу задуманной и уже в 1839 г. почти законченной К. С. Аксаковым диссертации о Ломоносове славянофил С. П. Шевырев в 1845 г. писал Гоголю: «Хороший и большой труд <...>. Но Гегель подпустил дыму, иногда и в мысль, а всего более в слог» [Гоголь. Т. 13: 198]. На письмо Шевырева о труде Аксакова Гоголь отвечал: «Что же касается до диссертации его, то, еще не читая ее, советовал ему не подавать ее, даже уничтожить ее вовсе...» [Гоголь. Т. 13: 212].

Достаточно в качестве примера привести лишь одну фразу из аксаковской диссертации: «Отрицание само есть вместе и подтверждение; вспомним, что мы ничего не видим, кроме отрицания; в таком случае отрицая вещь, мы ее признаем, и становим моментом самое отрицание» [Аксаков К. С., 1846: 18]. Таким слогом написана большая часть диссертации К. С. Аксакова о русском поэте Ломоносове. Как уже указывалось, еще Пушкин в 1836 г. говорил, что «философия немецкая» нашла в Москве «слишком много молодых последователей», - и высказывал пожелание, чтобы ее сменил «дух более практический» [Пушкин: 18].

Но диссертацию Константина Аксакова отличает не только ее «немецкий» стиль. В работе юного оппозиционера-славянофила сквозит и «подковерное», подцензурное недоброжелательство к самому Ломоносову. Более откровенно Аксаков излагал свое критическое отношение к ломоносовскому наследию в частных письмах. Эти высказывания ничем не отличают его от Белинского, бывшего его московского друга, который, подразумевая глубокий монархизм Ломоносова и Державина, не раз высказывался в их адрес весьма негативно. Дошло до того, что либералы за оды русских писателей царям объявили русскую литературу XVIII в. вообще несуществующей. Не только Гоголь, возражавший

${ }^{1}$ Цит. по первой публикации: [Жихарев: 44-45]. 
К. С. Аксакову, но и ранее Пушкин вынужден был защищать от нападок Андрея Тургенева, Бестужева, Кюхельбекера, того же Ивана Киреевского, Веневитинова, Ксенофонта Полевого, Белинского достоинство русской словесности XVIII столетия - ее абсолютное не «ничтожество», а богатство и высокий статус [Виноградов, 2019]. Современные исследователи, в отличие от Пушкина и Гоголя, до сих пор не отдают себе отчета в сути этой декабристской негативистской критики.

Имея в виду все перечисленные назидания Гоголя в адрес Аксакова: и по поводу критики «Одиссеи» и «Домостроя», и по поводу нигилистического отношения к русской поэзии, начиная с Ломоносова, и насчет эпатирующего ношения кафтана и бороды, и против фарисейской «кичливости» и "хвастовства», с неразумной «прыткостью» и скороспелостью, и в опровержение неприязни приятеля к «дому Романовых», и как реакцию на его «оппозиционное» противопоставление Москвы правительственному Петербургу, и для искоренения пристрастия славянофила к немецкой схоластике, - подразумевая все эти гоголевские обличения, можно сделать вывод, что К. С. Аксаков «с полным правом» мог заслужить от писателя в «Выбранных местах из переписки с друзьями» такое же обличение - и едва ли не большее, какое получил Погодин.

В то же время, очевидно, что адресованная друзьям гоголевская критика раздается не «слева» - не с чуждой, неприемлемой для писателя западнической позиции, а, напротив, «справа» и «сверху», т. е. с еще более высокой, духовной точки зрения, с платформы еще более консервативных, «еще более славянофильских» взглядов. Западники, по оценке писателя, только еще начинают сознавать свои заблуждения. Куда дальше вперед от них ушли «восточники». Но и те, будучи на пути к истине, достаточным потенциалом для выполнения задачи общенационального строительства еще не обладают. Хотя и в меньшей мере, они тоже не дозрели для того, чтобы быть достойными проводниками "русского духа по русской земле» [Гоголь. Т. 13: 388]. Процесс только в самом начале: «...Мы начинаем просыпаться, но еще не вполне проснулись...» [Гоголь. Т. 6: 51]. Для чаемого построения жизни по самобытным, православным началам сделано до сих пор крайне мало: «...Славянисты <..> хвастуны; из них каждый <...> найденное им зернышко раздувает в репу» [Гоголь. Т. 6: 52]. К примеру, Ю. Ф. Самарин в письме к К. С. Аксакову из Петербурга в Москву в феврале 1845 г. тоже 
указывал на незначительный в целом тогдашний вклад славянофилов в общее дело: «Мы ещё ничего не доказали или очень немногое; всё, что мы утверждаем о нашей истории, о нашем народе, об особенностях нашего прошедшего развития, всё это угадано, а не выведено» [Самарин: 156]. Словом, хотя западники, несомненно, от истины дальше, однако мировоззрение и раздражающая многих, скороспелая деятельность «славянистов» тоже ещё не способны «внести в самые огрубелые души святыню» народной жизни - «вызвать нам <...> нашу русскую Россию: не ту, которую показывают нам грубо какие-нибудь квасные патриоты, и не ту, которую вызывают к нам из-за моря очужеземившиеся русские» [Гоголь. Т. 6: 196].

Мнение об «изолированности» Гоголя от полемики славянофилов и западников, представление о том, будто писатель находился «между стульями» славянофильства и западничества, являются несостоятельными. Роль Гоголя в современных ему движениях была во многом уникальной. Будучи славянофилом-«государственником», убежденным сторонником единства славян и идеологом и защитником единственной в славянском мире мощной государственности, славянской русской державы, создатель «Тараса Бульбы» продолжал линию Н. М. Карамзина, С. С. Уварова, М. П. Погодина, С. П. Шевырева, святителя Петра Цетинского, протоиерея Матфея Константиновского. Словом, Гоголь стоял определенно выше многих представителей как западнического, так и славянофильского направлений, ибо по целому ряду вопросов превосходил не только далеких от него западников, но и гораздо более близких ему «восточников», которые тоже не достигали масштабности и объективности гоголевского художнического видения.

\section{Список литературы}

Аксаков И. С. Письма к родным. 1844-1849. Издание подготовила И. Ф. Пирожкова. М., 1988. 704 с.

$<$ Аксаков К. С.> Ломоносов в истории русской литературы и русского языка. Рассуждение кандидата Московского Университета Константина Аксакова, писанное на степень магистра философского факультета первого отделения. М.: В типографии Николая Степанова, 1846. 522 с.

$<$ Аксаков К. С.> Неизданные письма из-за границы К. С. Аксакова, 1838 года, с примечаниями Г. М. Князева (продолжение) // Космополис. (Cosmopolis). СПб., 1898. Т. 10. № 4. Апрель. С. 74-88.

Алленов М. М. Александр Андреевич Иванов. М.: Изобразительное искусство, 1980. 206 c. 
Белинский В. Г. Полн. собр. соч.: В 13 т. М., 1956. Т. 12.596 с.

Варнава (Беляев), епископ. Основы искусства святости. Опыт изложения православной аскетики. В 4 т. Нижний Новгород, 1996. Т. 1. 478 с.

Виноградов И. А. «Спасен я был Государем». Неизвестное письмо Н. В. Гоголя к Императору Николаю Павловичу и его отношение к монархии // Литература в школе. 1998. № 7. С. 5-22.

Виноградов И. А. Александр Иванов в письмах, документах, воспоминаниях. Научное издание. М.: ИД «ХХІ век - Согласие», 2001. 776 с.

Виноградов И. А. Комментарий // Гоголь Н. В. Тарас Бульба. Автографы, прижизненные издания. Историко-литературный и текстологический комментарий. Издание подготовил И. А. Виноградов. М.: ИМЛИ РАН, 2009. С. 387-656.

Виноградов И. А. Гоголь в воспоминаниях, дневниках, переписке современников. Полный систематический свод документальных свидетельств. Научно-критическое издание: в 3 т. М., ИМЛИ, 2012. Т. 2. 1031 с.

Виноградов И. А. Отеческое попечение: Император Николай І в судьбе Гоголя // Studia Litterarum. 2016a. Т. 1. № 1-2. С. 269-277.

Виноградов И. А. Гоголь о поэзии и схоластике. (К авторскому определению жанра «Мертвых душ») // Творчество Н. В. Гоголя и европейская культура. Пятнадцатые Гоголевские чтения / Под общ. ред. В. П. Викуловой. М.; Новосибирск: Новосиб. изд. дом, 2016б. С. 226-233.

Виноградов И. А. Славянофильство русское, польское и украинское: Н. В. Гоголь, А. Мицкевич и О. М. Бодянский // Гоголь и славянский мир. Шестнадцатые Гоголевские чтения / Под общ. ред. В. П. Викуловой. М.; Новосибирск: Новосибирский издательский дом, 2017а. С. 69-77.

Виноградов И. А. Гоголь и западное славянофильство: К постановке проблемы // Studia Litterarum. 2017. № 4. С. 182-207.

Виноградов И. А. Космополит или патриот? Концепция патриотизма в спорах с Гоголем и о Гоголе // Проблемы исторической поэтики. Петрозаводск, 2017в. Т. 15. № 3. С. 35-69.

Виноградов И. А. Летопись жизни и творчества Н. В. Гоголя (1809-1852): в 7 т. М.: ИМЛИ РАН, 2017г. Т. 2: 1829-1836; Т. 4: 1842-1844. 672 + 704 с.

Виноградов И. А. Летопись жизни и творчества Н. В. Гоголя (1809-1852). Научное издание. В 7 т. Т. 5. 1845-1847а. М.: ИМЛИ РАН, 2018. 928 с.

Виноградов И. А. Литературная проповедь Н. В. Гоголя: pro et contra // Проблемы исторической поэтики. 20186. Т. 16. № 2. С. 49-124.

Виноградов И. А. «Когда в товарищах согласья нет...» А. С. Пушкин, Н. В. Гоголь, С. С. Уваров // Два века русской классики. 2019. Т. 1. № 1. С. 34-103.

Вяземский П. А., князь. Языков. - Гоголь // Санкт-Петербургские Ведомости. 1847. 24 апр. № 90. С. 417-418.

Гериен А. И. Собр. соч.: В 30 т. М.: Изд-во АН СССР, 1956. Т. 7. 468 с.

Гиллельсон М. Неизвестные публицистические выступления П. А. Вяземского и И. В. Киреевского // Русская литература. 1966. № 4. С. 120-134.

Гиллельсон М. И. П. А. Вяземский. Жизнь и творчество. Л.: Наука, 1969. 393 с. 
Гоголь Н. В. Полн. собр. соч. и писем: В 17 т. (15 кн.) / сост., подгот. текстов и коммент. И. А. Виноградова, В. А. Воропаева. М.; Киев: Изд-во Московской Патриархии, 2009-2010.

T. VI. Выбранные места из переписки с друзьями. Духовная проза. Критика. Публицистика.744с.;

T. VII. Юношеские опыты. Первоначальные редакции. 816 с.

T. XII. Переписка 1842-1844. 704 с.;

T. XIII. Переписка 1845-1846. 592 с.;

T. XIV. Переписка 1847. 606 с.;

T. XV. Переписка 1848-1852. 624 c.

Гоголь в неизданной переписке современников (1833-1853) / Публикация и комментарии Л. Ланского <Л. Р. Каплана > // Лит. наследство. М., 1952. Т. 58. С. 533-772.

<Долдобанов Г. И., Сидоров И. С.> Хроника жизни и творчества А. С. Пушкина. В 3 т. 1826-1837. М.: ИМЛИ РАН, 2016. Т. 3. Кн. 1. 1835-сентябрь 1836 / Сост. Г. И. Долдобанов, И. С. Сидоров. 872 с.

Жихарев М. И. Петр Яковлевич Чаадаев. Из воспоминаний современника. Статья вторая // Вестник Европы. 1871. № 9. С. 9-54.

Зуммер В. М. О вере и храме А. Иванова. С IV таблицами (42 снимка). Издание журнала «Христианская Мысль». Киев, 1918. 60 с.

Игнатий Брянчанинов, святитель. Письма. М., 1993. Т. 7. 480 с.

$<$ Киреевский И. В.> Житие Молдавского Старца Паисия Величковского (Житие и подвиги Отца нашего Старца Паисия, Архимандрита Молдавских святых монастырей Нямецкого и Секула; Писания Старца Паисия, Архимандрита Молдовлахийския Нямецкия обители; Оглавление) // Москвитянин. 1844. № 4 (цензурное разрешение 26 мая). <Отд. 4>. С. 1-78.

$<$ Киреевский И. В.> Отрывки, найденные в бумагах И. В. Киреевского. <Продолжение статьи «О необходимости и возможности новых начал для философии»> // Русская Беседа. Год второй. Кн. 5. 1857. № 1. Отд. 2. С. 1-24.

Лавеле Э., де. Балканский полуостров / Пер. с фр. с примеч. и доп. Н. Е. Васильева. Издание Н. Т. Солдатенкова. М.: Типография В. В. Исленьева, 1889. 1122 с.

<Лебедев К. Н.> Из записок сенатора К. Н. Лебедева // Русский Архив. 1910. № 12 . С. 540-582.

Лясковский В. Н. Братья Киреевские. Жизнь и труды их. СПб., 1899. 99 с.

Мартынов В. А. У истоков «русской идеи»: жизнь и судьба С. П. Шевырева. М.: Форум, 2013. 280 с.

$<$ Петр Цетинский>. Святой Петр Цетинский - патриарх нового времени / Пер. с серб.: С. А. Луганская, Г. В. Рачук, М. Тодич, И. М. Числов. М.: Сибирская Благозвонница, 2015. 621 с.

Пирожкова Т. Ф. Примечания // Аксаков И. С. Письма к родным. 1844-1849 / изд. подгот. Т. Ф. Пирожкова. М.: Наука, 1988. С. 554-684.

Пушкин А. С. Москва // Соч. Александра Пушкина. СПб.: В типографии И. Глазунова и $\mathrm{K}^{0}, 1841$. Т. 11. С. 13-18.

Розанов А. С. Ф. Лист в Риме в 1839 г. (по материалам семейного архива графов Виельгорских) // Памятники культуры. Новые открытия. Ежегодник. 1983. Л., 1985. С. 295-303. 
Сагарда Н. И. Славянофильство и его идеалы. (Речь, произнесенная в актовом зале Полтавской духовной семинарии 11 Мая - в день памяти свв. первоучителей славян Кирилла и Мефодия) // Полтавские Епархиальные Ведомости. 1902. 1 июля. № 19. Часть неоффициальная. С. 865-876.

Сакулин П. Н. Из истории русского идеализма. Князь В. Ф. Одоевский. Мыслитель. Писатель. М.: Издание М. и С. Сабашниковых, 1913. Т. 1. Ч. 1.616 с.

[Самарин Ю. Ф.] Сочинения Ю. Ф. Самарина. М.: Товарищество типографии А. И. Мамонтова, 1911. Т. 12. Письма 1840-1853. 478 с.

Срезневский И. И. На память о Бодянском, Григоровиче и Прейсе, первых преподавателях славянской филологии // Сборник Отделения русского языка и словесности Императорской Академии наук. 1878. Т. XVIII. № 6. С. 1-47.

Хомяков А. С. Полн. собр. соч.: <в 8 т.> М.: Унив. тип., 1900. Т. 8.480 - 58 с.

\section{References}

Aksakov I. S. Pis'ma k rodnym. 1844-1849 [Letters to relatives. 1844-1849]. Moscow, 1988. 704 p. (In Russ.)

Aksakov K. S. Lomonosov $v$ istorii russkoj literatury i russkogo jazyka. Rassuzhdenie kandidata Moskovskogo Universiteta Konstantina Aksakova, pisannoe na stepen' magistra filosofskogo fakul'teta pervogo otdelenija [Lomonosov in the history of Russian literature and Russian language. The reasoning of the candidate of the Moscow University Konstantin Aksakov, written for the master's degree of the Faculty of Philosophy of the first department]. Moscow, V tipografii Nikolaja Stepanova Publ., 1846. 522 p. (In Russ.)

Aksakov K. S. Neizdannye pis'ma iz-za granicy K. S. Aksakova, 1838 goda, s primechanijami G. M. Knjazeva (prodolzhenie) [Unedited letters from abroad, ed. By K. S. Aksakov, 1838, with notes by G.M. Knyazev (continued)]. Kosmopolis. (Cosmopolis). Sankt-Peterburg, 1898, vol. 10, № 4, April, pp. 74-88. (In Russ.)

Allenov M. M. Aleksandr Andreevich Ivanov. Moscow: Izobrazitel'noe iskusstvo Publ., 1980. 206 p. (In Russ.)

Belinskij V. G. Polnoe sobranie sochinenij: V 13 tomah [Complete Works: In 13 vols]. Moskva: Izdatel'stvo of the Academy of Sciences of the USSR Publ., 1956, vol. 12. 596 p. (In Russ.)

Varnava (Beljaev), Bishop. Osnovy iskusstva svjatosti. Opyt izlozhenija pravoslavnoj asketiki [The basics of the art of holiness. The experience of the presentation of Orthodox asceticism]. In 4 vol. Nizhny Novgorod, 1996, vol. 1. 478 p. (In Russ.)

Vinogradov I. A. «Spasen ja byl Gosudarem». Neizvestnoe pis'mo N. V. Gogolja k Imperatoru Nikolaju Pavlovichu i ego otnoshenie k monarhii ["I was saved by the Sovereign". Unknown letter N. V. Gogol to the Emperor Nikolai Pavlovich and his attitude to the monarchy]. Literatura $v$ shkole [Literature at school]. 1998, № 7, pp. 5-22. (In Russ.)

Vinogradov I. A. Aleksandr Ivanov v pis'mah, dokumentah, vospominanijah. Nauchnoe izdanie [Alexander Ivanov in letters, documents, memoirs. Scientific publication]. Moscow, Izdatel'skij Dom «XXI vek - Soglasie» Publ., 2001. 776 p. (In Russ.)

Vinogradov I. A. Kommentarij [Comment]. Gogol' N. V. Taras Bul'ba. Avtografy, prizhiznennye izdanija. Istoriko-literaturnyj i tekstologicheskij kommentarij [Taras Bulba. 
Autographs, lifetime editions. Historical and literary and textual commentary]. The publication was prepared by I. A. Vinogradov. Moscow, A. M. Gorky Institute of World Literature of the Russian Academy of Sciences Publ., 2009, pp. 387-656. (In Russ.)

Vinogradov I. A. Gogol'v vospominaniiakh, dnevnikakh, perepiske sovremennikov. Polnyi sistematicheskii svod dokumental'nykh svidetel'stv [Gogol in contemporaries' memoirs, diaries and correspondence. Full systematic set of documentary evidence]. In 3 v. Moscow, A. M. Gorky Institute of World Literature of the Russian Academy of Sciences Publ., 2013. Vol. 2. 1032 p. (In Russ.)

Vinogradov I. A. Otecheskoe popechenie: Imperator Nikolaj I v sud'be Gogolja [Fatherland care: Emperor Nicholas I in the fate of Gogol]. Studia Litterarum, 2016, vol. 1, № 1-2, pp. 269-277. (In Russ.)

Vinogradov I. A. Gogol' o pojezii i sholastike. (K avtorskomu opredeleniju zhanra «Mertvyh dush») [Gogol about poetry and scholasticism. (To the author's definition of the genre of "Dead Souls")]. Tvorchestvo N. V. Gogolja i evropejskaja kul'tura. Pjatnadcatye Gogolevskie chtenija [Creativity N. V. Gogol and European culture. Fifteenth Gogol reading]. Under the general editorship of V. P. Vikulova. Moskva, Novosibirsk, Novosibirskij izdatel'skij dom Publ., 2016, pp. 226-233. (In Russ.)

Vinogradov I. A. Gogol' i zapadnoe slavjanofil'stvo: K postanovke problemy [Gogol and Western Slavophilism: To the formulation of the problem]. Studia Litterarum, 2017, № 4, pp. 182-207. (In Russ.)

I. A. Kosmopolit ili patriot? Koncepcija patriotizma v sporah s Gogolem i o Gogole [Cosmopolitan or patriot? The concept of patriotism in disputes with Gogol and Gogol]. Problemy istoricheskoj pojetiki [Problems of historical poetics]. Petrozavodsk, 2017, vol. 15, № 3, pp. 35-69. (In Russ.)

Vinogradov I. A. Slavjanofil'stvo russkoe, pol'skoe i ukrainskoe: N. V. Gogol', A. Mickevich i O. M. Bodjanskij [Slavophilism is Russian, Polish and Ukrainian: N. V. Gogol, A. Mitskevich and O. M. Bodyansky]. Gogol' i slavjanskij mir. Shestnadcatye Gogolevskie chtenija [Gogol and the Slavic world. Sixteenth Gogol Readings]. Edited by V. P. Vikulova. Moscow, Novosibirsk, Novosibirskij izdatel'skij dom Publ., 2017, pp. 69-77. (In Russ.)

Vinogradov I. A. Letopis' zhizni i tvorchestva N. V. Gogolja (1809-1852). Nauchnoe izdanie. V 7 tomah [Chronicle of the life and work of N. V. Gogol (1809-1852). Scientific publication. In 7 volumes]. Moscow, A. M. Gorky Institute of World Literature of the Russian Academy of Sciences Publ., 2017, vol. 2: 1829-1836. 672 p. (In Russ.)

Vinogradov I. A. Letopis' zhizni i tvorchestva N. V. Gogolja (1809-1852). Nauchnoe izdanie. V 7 tomah [Chronicle of the life and work of N. V. Gogol (1809-1852). Scientific publication. In 7 volumes]. Moscow, A. M. Gorky Institute of World Literature of the Russian Academy of Sciences Publ., 2018, vol. 5: 1845-1847. 928 p. (In Russ.)

Vinogradov I. A. Literaturnaja propoved' N. V. Gogolja: pro et contra [Literary sermon N. V. Gogol: pro et contra]. Problemy istoricheskoj pojetiki [Problems of historical poetics], 2018, vol. 16, № 2, pp. 49-124. (In Russ.)

Vinogradov I. A. «Kogda v tovarishchakh soglas'ia net...» A. S. Pushkin, N. V. Gogol', S. S. Uvarov ["When there is no agreement in comrades..." A. S. Pushkin, N. V. Gogol, 
S. S. Uvarov]. Dva veka russkoi klassiki [Two centuries of Russian classics], 2019, vol. 1, № 1, pp. 34-103. (In Russ.)

Vjazemskij P. A., the prince. Jazykov. - Gogol' [Yazykov. — Gogol]. Sanktpeterburgskie Vedomosti [St. Petersburg Vedomosti], 1847, April 24, № 90, pp. 417-418. (In Russ.)

Gercen A. I. Sobranie sochinenij: V 30 t. [Collected Works: 30 volumes]. Moscow, Izdatel'stvo Akademii nauk SSSR Publ., 1956, tom 7. 468 p. (In Russ.)

Gillel'son M. Neizvestnye publicisticheskie vystuplenija P. A. Vjazemskogo i I. V. Kireevskogo [Unknown journalistic speeches of P. A Vyazemsky and I. V. Kireyevsky]. Russkaja literatura [Russian literature], 1966, № 4, pp. 120-134. (In Russ.)

Gillel'son M. I. P. A. Vjazemskij. Zhizn' i tvorchestvo [P. A. Vyazemsky. Life and art]. Leningrad: Nauka Publ., 1969. 393 p. (In Russ.)

Gogol' N. V. Poln. sobr. soch. i pisem: V 17 t. (15 kn.) [Full collected works and letters in 17 vol. (15th book)], sost., podgot. tekstov i komment. I. A. Vinogradova, V. A. Voropaeva. M.; Kiev, Izd-vo Moskovskoi Patriarkhii Publ, 2009, vol. 6-7, 12-15. 744, 816, 704, 592, 608, 624 p. (In Russ.)

Gogol' v neizdannoj perepiske sovremennikov (1833-1853) [Gogol in unpublished correspondence of contemporaries (1833-1853)]. Publication and commentary L. Lansky $<$ L. R. Kaplan $>$. Literaturnoe nasledstvo [Literary heritage]. Moscow, 1952, vol. 58, pp. 533-772. (In Russ.)

Doldobanov G. I., Sidorov I. S. Khronika zhizni i tvorchestva A. S. Pushkina. V 3 tomakh. 1826-1837 [The Chronicle of the Life and Works of A. S. Pushkin. In 3 volumes. 1826-1837], compiled by G. I. Doldobanov, I. S. Sidorov. Moscow, A. M. Gorky Institute of World Literature of the Russian Academy of Sciences Publ., 2016, vol. 3, book 1, 1835 - September 1836. 872 p. (In Russ.)

Zhiharev M. I. Petr Jakovlevich Chaadaev. Iz vospominanij sovremennika. Stat'ja vtoraja [Petr Yakovlevich Chaadaev. From the memoirs of a contemporary. Article Two]. Vestnik Evropy [Herald of Europe], 1871, № 9, pp. 9-54. (In Russ.)

Zummer V. M. O vere i hrame A. Ivanova. S IV tablicami (42 snimka) [About faith and the temple of A. Ivanov. With IV tables (42 pictures)]. Izdanie zhurnala «Hristianskaja Mysl'» Publ. Kiev, 1918. 60 p. (In Russ.)

Ignatij Brjanchaninov, prelate. Pis'ma [Letters]. Moscow, 1993, vol. 7. 480 p. (In Russ.)

Kireevskii I. V. Zhitie Moldavskogo Ctartsa Paisiia Velichkovskogo [The Life of the Moldavian Starts Paisius Velichkovsky]. Moskvitianin [Moskvityanin], 1844, № 4, branch 4, pp. 1-78. (In Russ.)

Kireevskij I. V. Otryvki, najdennye v bumagah I .V. Kirevskogo. [Prodolzhenie stat'i "O neobhodimosti i vozmozhnosti novyh nachal dlja filosofii»] [Excerpts found in the papers of I. V. Kirevskogo. [Continuation of the article "On the Necessity and Possibilities of New Beginnings for Philosophy"].]. Russkaja Beseda [Russian Conversation], 1857, second year, book, № 1, division 2, № 1, pp. 1-24. (In Russ.)

Lavele E., de. Balkanskii poluostrov [Balkan Peninsula]. Translation from French with remarks and additions N. Ye. Vasilyev. Edition N. T. Soldatenkov. Moscow: The printing house of V. V. Islenev Publ., 1889. 1122 p.

Lebedev K. N. Iz zapisok senatora K. N. Lebedeva [From the notes of Senator K. N. Lebedev]. Russkij Arhiv [Russian Archive], 1910, № 12, pp. 540-582. (In Russ.) 
Liaskovskii V. N. Brat'ia Kireevskie. Zhizn' i trudy ikh [The Kireevsky brothers. Life and their work]. St. Petersburg, 1899. 99 p. (In Russ.)

Martynov V. A. U istokov "russkoi idei»: zhizn' i sud'ba S. P. Shevyreva [At the source of the "Russian idea": the life and fate of S. P. Shevyrev]. Moscow: Forum Publ., 2013. 280 p. (In Russ.)

Petr Tsetinskii]. Sviatoi Petr Tsetinskii - patriarkh novogo vremeni [Saint Peter Tsetinsky - patriarch of the new time]. Translation from Serbian S. A. Luganskaya, G. V. Rachuk, M. Todich, I. M. Chislov. Moscow: Siberian Spinebone Publ., 2015. 621 p. (In Russ.)

Pirozhkova T. F. Primechanija [Notes]. Aksakov I. S. Pis'ma k rodnym. 1844-1849 [Letters to relatives. 1844-1849]. Edition prepared by T. F. Pirozhkova. Moscow, Nauka Publ., 1988, pp. 554-684. (In Russ.)

Pushkin A. S. Moskva [Moscow]. Soch. Aleksandra Pushkina [Works of Alexander Pushkin]. St. Petersburg: V tipografii I. Glazunova i Ko Publ., 1841, vol. 11, pp. 13-18. (In Russ.)

Rozanov A. S. F. List v Rime v 1839 g. (po materialam semeinogo arkhiva grafov Viel'gorskikh) [Liszt in Rome in 1839 (according to the materials of the family archive of the graphs of the Wielgorsky)]. Pamiatniki kul'tury. Novye otkrytiia. Ezhegodnik [Monuments of culture. New discoveries. Yearbook]. Leningrad, 1985, pp. 295-303. (In Russ.)

Sagarda N. I. Slavjanofil'stvo i ego idealy. (Rech', proiznesennaja v aktovom zale Poltavskoj duhovnoj seminarii 11 Maja — v den' pamjati svv. pervouchitelej slavjan Kirilla i Mefodija) [Slavophilism and its ideals. (A speech delivered in the assembly hall of the Poltava Theological Seminary on May 11 - on the day of memory of the holy teachers of the Slavs Cyril and Methodius)]. Poltavskie Eparhial'nye Vedomosti [Poltava Diocesan Vedomosti], 1902, July 1, № 19, part unofficial, pp. 865-876. (In Russ.)

Sakulin P. N. Iz istorii russkogo idealizma. Kniaz' V. F. Odoevskii. Myslitel'. - Pisatel' [From the history of Russian idealism. Prince V. F. Odoyevsky. Thinker. - Writer]. Moscow: Edition of M. and S. Sabashnikovs, 1913, vol. 1 part 1.616 p. (In Russ.)

Samarin Ju. F. Sochinenija Jurija Fedorovicha Samarina: $<v 12$ t. $>$ [Works of Yuriy Samarin: 12 volumes] Moscow, Tovariwestvo tipografii A. I. Mamontova Publ., 1911, vol. 12: Letters, 1840-1853. 478 p. (In Russ.)

Sreznevskii I. I. Na pamiat' o Bodianskom, Grigoroviche i Preise, pervykh prepodavateliakh slavianskoi filologii [In memory of Bodyansky, Grigorovich and Preis, the first teachers of Slavic philology]. Sbornik Otdeleniia russkogo iazyka $i$ slovesnosti Imperatorskoi Akademii nauk [Collection of the Department of Russian Language and Literature of the Imperial Academy of Sciences], 1878, vol. XVIII, № 6, pp. 1-47. (In Russ.)

Homjakov A. S. Poln. sobr. soch. Alekseja Stepanovicha Homjakova: $v 8$ tomah [Full collected works Alexey Stepanovich Khomyakov: in 8 volumes]. Moscow, Universitetskaja tipografija Publ., 1900, vol. 8: Letters. 48058 p. (In Russ.) 


\section{Рукописное собрание В. Ф. Одоевского, как источник по изучению теории древнерусского пения}

Аннотация: В статье рассматриваются вопросы, связанные с возвращением к исконной древнерусской певческой традиции в теории и практике церковного пения в России 1850-х - 1860-х гг. XIX в. и ведущая роль в данном процессе музыковеда и музыкального теоретика В. Ф. Одоевского. Раскрывается состав и содержание хранящегося в Отделе рукописей Российской государственной библиотеки рукописного собрания Одоевского, включающего крупнейшие музыкально-теоретические труды XVII в., которые отражают развитие певческой мысли того времени: нотные азбуки крюковые, двоезнаменные, на линейных нотах; различные сборники песнопений, хрестоматии по церковному пению, рассматривается деятельность Одоевского в «Обществе древнерусского искусства» при Румянцевском музее, в том числе работа по изготовлению шрифтов для издания крюковых нот. Одоевский стоял у истоков работ по исправлению нотных книг богослужебного пения, благодаря его усилиям в Московской консерватории была создана кафедра русского церковного пения, в программу обучения которой вошли лекции по истории церковного пения.

Ключевые слова: В. Ф. Одоевский, знаменное пение, древнерусская музыка, рукописное собрание, азбуки нотного пения

Информация об авторе: Вишневская Евгения Эдуардовна, кандидат исторических наук, «Российская государственная библиотека», ул. Воздвиженка, 3/5, 119019, г. Москва, Россия

E-mail: vishnevskayaee@rsl.ru

Дата поступления статьи в редакиию: 22.10 .2019

Дата публикации статьи: 10.12.2019

Для цитирования: Вишневская Е. Э. Рукописное собрание В. Ф. Одоевского, как источник по изучению теории древнерусского пения // Два века русской классики. 2019. T. 1. № 2. C. 62-77. DOI 10.22455/2686-7494-2019-1-2-62-77 
This is an open access article distributed under the Creative

Commons Attribution 4.0

International (CC BY 4.0)

(C) 2019. Eugenia E. Vishnievskaya

Moscow, Russia

\section{Handwritten collection of V. F. Odoyevsky as a sourceon the Study of the Theory of Ancient Russian Singing}

Abstract: The article deals with issues related to the return to the native ancient Russian singing tradition in the theory and practice of church singing in Russia of the 1850-s 1860 -s of the 19th century and the leading role in this process of the musicologist and musical theorist V. F. Odoyevsky. The composition and the content of Odoevsky's manuscript collection, which is stored in the Department of manuscripts of the Russian state library, including the largest musical and theoretical works of the XVII century, is revealed. It reflects the development of singing thought of the time: note codes hooks, double-character codes, note codes hooks on linear notes; various collections of songs, chrestomathies on church singing. The activity of Odoyevsky in the "Society of Ancient Russian Art" at the Rumyantsev Museum, including the work on the creation of fonts for the publication of hook notes, is considered. Odoevsky stood at the origins of the work on correcting the music books of liturgical singing, thanks to his efforts, a department of Russian church singing was created at the Moscow Conservatory, which included lectures on the history of church singing in its the curriculum.

Keywords: V. F. Odoyevsky, church singing, ancient Russian music, manuscript'scollection, alphabets of note singing

Information about the author: Vishnievskaya Eugenia Eduardova, Candidate of Historical Sciences, Russian State Library, 3/5, 119019, Moscow, Russia.

E-mail: vishnevskayaee@rsl.ru

Received: October 22, 2019

Published: December 10, 2019

For citation: Vishnevskaya E. E. Manuscript collection of V. F. Odoyevsky, as a source for studying the theory of ancient Russian singing // Two centuries of the Russian classics, 2019, vol. 1, № 2, pp. 62-77. (In Russ.) DOI 10.22455/2686-7494-2019-1-2-62-77 
Владимир Федорович Одоевский (1804-1869) - не только ученый, стоявший у истоков осмысления тенденций церковно-певческой жизни России второй половины XIX и начала XX столетия и их реформирования, музыкальный теоретик и критик, но и владелец ценнейшего книжного собрания. Его библиотека, с любовью собираемая владельцем, служила князю необходимым рабочим инструментом, помогавшим в научных изысканиях. С ней работали при подготовке научных сочинений многие его друзья - знаменитые и достойные люди, оставившие в ней память, преподнеся Владимиру Федоровичу книги со своими автографами.

Рукописная часть книжного собрания Одоевского хранится в Отделе рукописей Российской государственной библиотеки (ОР РГБ) с 1869 г. Библиотека Одоевского, которая составляла более 6 тыс. книг и брошюр, была практически полностью безвозмездно передана вдовой князя О. С. Одоевской в Румянцевский музей с тем условием, чтобы она «...была помещена в здании Музеума в виде отдельного собрания под именем князя В. Ф. Одоевского» [Архив РГБ. Оп. 1. Ед. хр. 105. Л. 6-7]. Собрание рукописных книг (Фонд № 210. Одоевский) содержит 45 единиц хранения. Основу его составляют певческие рукописи: азбуки; сборники песнопений на крюковых и линейных нотах для пения в унисон и на несколько голосов; статья Одоевского «О цифирной методе обучения музыкальной грамоте» и другие материалы.

Возникновение русского богослужебного пения неразрывно связано со становлением русского монашества, с глубинной сутью монашеского подвига. В 1860-х гг. церковное пение как часть древнерусской традиции стало предметом изучения музыковедов. В конце 1850-х гг. Одоевский являлся центральной фигурой, вокруг которой формировалась новая наука о церковном пении. Владимир Федорович был ведущим специалистом в области теории церковной музыки, ученым, стоявшим у истоков осмысления тенденций церковно-певческой жизни России, сохранения и приумножения богатейших традиций. 


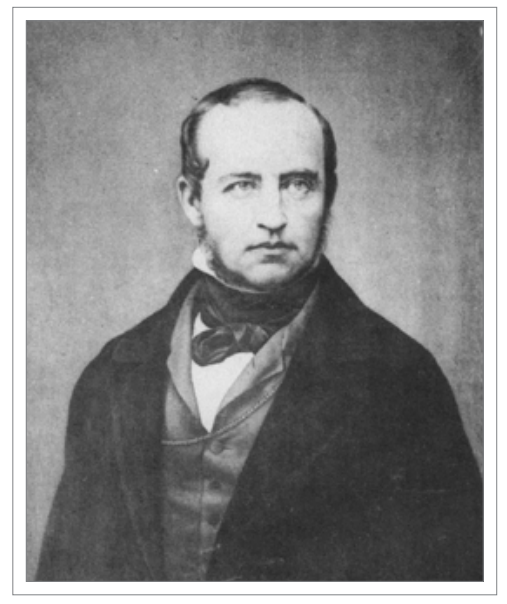

В. Ф. Одоевский. 1850-е г2.

Фото опубликовано в издании: Князь Владимир Одоевский: Дневник. Переписка. Материалы: К 200-летию со дня рождения. М, 2005. 524 c. Данное фото хранится в Фонде 73 ГЦММК.

В этот период он работал над подготовкой труда о древнерусской музыке, изучением которой он занимался многие годы. В письме к И. П. Сахарову от 19 октября 1860 г. он сообщил, что завершил книгу под заглавием «Опыт руководства к основным законам мелодии и гармонии для не-музыкантов, приспособленное [sic] преимущественно к чтению рукописей о нашем древнем песнопении» [Государственный центральный музей музыкальной культуры им. М. И. Глинки Ф. 73. Ед. хр. 270]. Он писал: «Вся эта номенклатура: гласи, осьмогласие, триестествогласие, погласицы, наконец самые крюки с степенными пометами, все это сделалось мне ясно, и, если я не обманут самолюбием, то будет ясно и для всех, для Вас, господ археологов; а Ваша помощь, господа, тут необходима; целый мир разработки Вам подготовлен, извольте кушать, а хозяина не хулить - угощает чем бог послал» [Одоевский, 1956: 515]. Эта работа была первой частью исследования о древнерусском песнопении. Одоевский готовил капитальный труд под названием «Осьмогласие», свидетельством чему являются многократные упоминания о нем в его дневнике. Труд этот не был завершен, а разошелся по статьям, письмам, фрагментам. В это время Одоевский 
опубликовал ряд работ музыкального содержания [Одоевский, 1858; Одоевский, 1863; Одоевский, 1864; Одоевский, 1867; Одоевский, 1869; Одоевский, 1871], в том числе труд «Музыкальная грамота или основания музыки для немузыкантов» - первый учебник по элементарной теории музыки на русском языке, напечатанный в России [Одоевский, 1868]. Его мысли и труды намного опережали время. К сожалению, не все работы Одоевского, связанные с церковным пением, были опубликованы при жизни или после смерти автора. Этот пробел частично был восполнен в XXI в., с выходом третьего тома серии «Русская духовная музыка в документах и материалах» [Русская духовная музыка...].

Знаменное пение - тип церковного пения, в основание которого положено одноголосное хоровое исполнение. Такое пение служило связующей нитью при обращении молящегося к Богу. Название «знаменное» происходит от использовавшихся для его записи особых знаков - знамен. Известно несколько основных безлинейных нотаций - знаменная нотация («столповое знамя»), демественная («демество»), путевое знамя («путь») и казанское знамя [Бражников: 421]. Древнейшие нотированные знаменами (крюками) рукописи имели «беспометную» нотацию, они трудно поддаются расшифровке. K XVII в. в крюковой записи появились дополнительные знаки - «пометы» и «призна́ки», что сделало знаменную нотацию более доступной. Также наравне с традиционным одноголосным пением появилось «народное» многоголосие (строчное пение), записанное крюками или знаменами. В XVII в. в рукописях появились «роспевы», «розводы» лиц, фит и сложных знамен (расшифровка сочетаний), кокизники (сборники «попевок») и фитники (сборники фит с объяснениями, изложенными «дробным знаменем»).

Расцвет богослужебного пения в XVII в. постепенно к XVIII в. сменялся его упадком. К числу влиятельных фактов следует отнести упразднение Петром I патриаршества на Руси, перенесение столицы из Москвы в Санкт-Петербург, закрытие большей части монастырей, секуляризацию монастырских земель. В области церковного пения в XVII в. на Руси распространялась западноевропейская традиция, знаменное пение постепенно вытеснялось европейским, названным «партесным» (многоголосным). Такой тип пения при внешней привлекательности уже не имел того духовного содержания, которым обладал знаменный распев. Некоторые композиторы предпринимали усилия по встраиванию «знаменных» мелодий в партесный обиход, гармони- 
зируя их в согласии с правилами западноевропейской гармонии. Появлялись новые виды рукописей - «двоезнаменники», в которых напев излагался двумя видами нотаций.

Возвращаясь к исконной русской певческой традиции, В. Ф. Одоевский применил знания о древнерусском песнопении к условиям своего времени. Он «...первым опубликовал статьи о теории нашей древней мелодии и гармонии», а «осмысление теории древнерусского искусства для Одоевского было одним из шагов к возрождению церковного пения», справедливо отмечает О. Б. Шевцова. - «Он в числе первых осознал необходимость возвращения к традициям в церковно-певческом искусстве после эпохи увлечения авторской музыкой, ориентированной на западные образцы. Идеальной формой церковной молитвы для него были древние уставные распевы, гармонизованные по правилам, созвучным национально своеобразному русскому церковному пению» [Шевцова: 1].

В рукописной части библиотеки Одоевского хранятся важнейшие музыкально-теоретические труды XVII в., отражающие развитие певческой мысли того времени. Это «Азбуки нотные» второй четверти XVII в. - 1866 г. Каждая из них заслуживает особого внимания. «Азбука знаменного пения. Книга, глаголемая Кокизы ${ }^{1}$, сиречь ключ столповому и казанскому знамени», открывает собрание Одоевского [ОР РГБ Ф. 210. № 1]². В рукописи представлен малоизученный редкий вид нотации - путно-демественное (или казанское) ${ }^{3}$ знамя, созданный в честь покорения Казани Иваном Грозным. Для наглядного описания названий фит и знамен процитируем небольшой отрывок содержания рукописи: «Сказание известно и рассужение существено фитам ирмосным и строкам, кулизмам полным и неполным, тряскам, змеицам и паукам и полукулизмам, и стрелам светлым, и полукрыжным, и поводным, и два в челну, и хамилу, и закрытым дербицам, и поздернутой - во всех осмигласех лица и розвод...» [Собрание В.Ф. Одоевского. Ф. 210: 2].

\footnotetext{
${ }^{1}$ Кокизы или Кокизники - своды попевок, составлявших основу знаменного распева.

2 Азбука знаменного пения. Книга, глаголемая Кокизы, сиречь ключ столповому и казанскому знамени. Вторая четверть XVII в.

3 Известны различные типы знаменного распева и соответствующие им типы знамён - кондакарный, столповой, демественный, путевой, ветвенный.
} 
К двоезнаменным рукописям относится «Азбука певческая, составленная с использованием “Ключа" Тихона Макарьевского» [ОР РГБ Ф. 210, № 2]. Книга включает рисунок «Горовосходного холма», отрывок из «Извещения о согласнейших пометах, изложиша здевъ кратце требующим учитися св. пения...», - часть списка знаменитого труда Александра Мезенца.

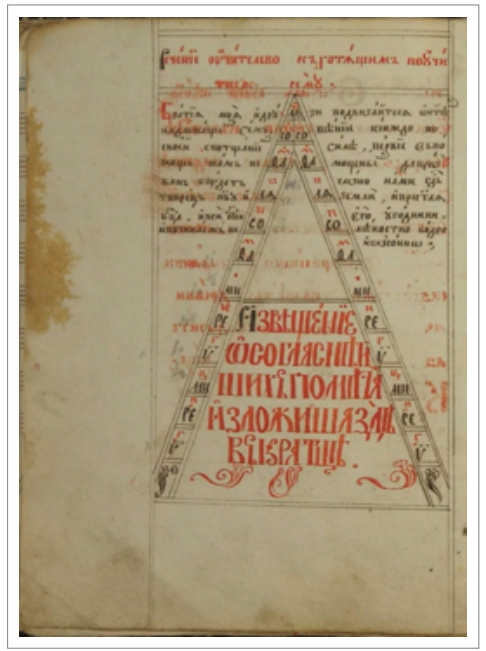

Азбука певческая, составленная с использованием Ключа Тихона Макарьевского из собрания В. Ф. Одоевского. Середина XVIII в. Полуустав. Л.10 об.-11. Разворот. Рисунок горовсходного холма. [ОР РГБ. Ф. 210 № 2].

В певческой азбуке звукоряд представлен как горовсходный холм, который содержит горку полную и горку основную. Звуки на нем располагаются в восходящем и нисходящем движении. Горка основная изображает шесть основных звуковых ступеней (ут-ре-ми-фа-соль-ля в мрачном и светлом согласиях).

Данная «Азбука...» - это учебник знаменного пения, написанный в 1668 г. и актуальный до сих пор. В нем объясняется система киноварных помет и призна́ков, беспризначные знамена и их имена; определяется последовательность согласий. При этом в рукописи перечислены начертания и названия знамен с пометами и их переложение на пятилинейную квадратную нотацию; описания лиц, фит и разводов и др. 
Более поздняя «Азбука знаменного пения» [ОР РГБ Ф. 210, № 3] собрания относится к середине XIX в. Согласно владельческой записи, она была получена Одоевским в 1855 г. от старообрядческого священника. Открывают рукопись начертания и названия знамен, далее следует «Ключ» Тихона Макарьевского. «Ключ разумения» - крупнейшие двоезнаменное музыкально-теоретическое сочинение конца XVII в. Его автор - музыкальный теоретик, историк, поэт и церковный деятель Тихон Макарьевский представил систему соотношения между древней знаменной и новой для России нотнолинейной «киевской» нотациями. «Ключ» дает подробную информацию о начертании знамен, их названиях, переводе на пятилинейную нотацию. В рукописи представлены рисунки «Ключа разумения» и «Горовосходного холма», разводы строк по гласам, фит, лиц. Завершают рукопись «Стихиры и подобны», «Азбука демественная с разводом на простое знамя» и различные песнопения.

Рукопись «Ключ Тихона Макарьевского. Сказание о нотном гласоступании, и о литерных знаменных пометах, и о нотном знамени, иже в сем Ключе написано по линиям, и испацыам простаго клявеся» [ОР РГБ

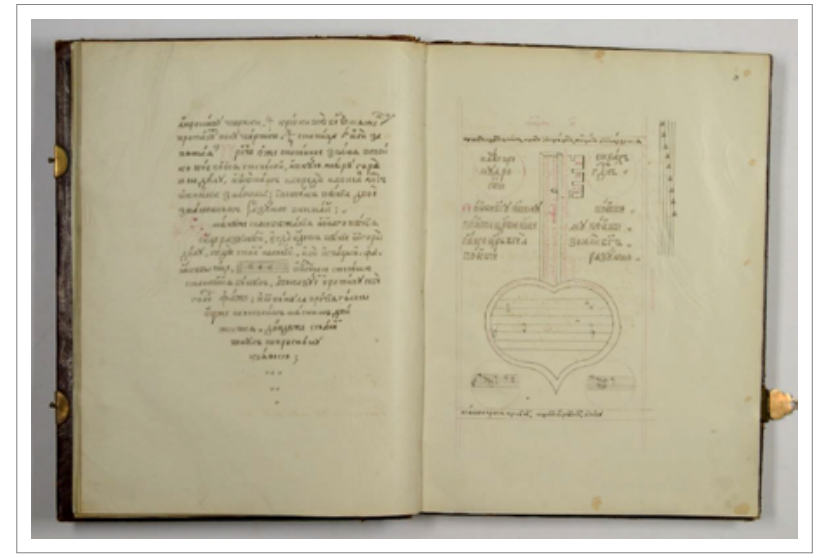

Ключ Тихона Макарьевского. Разворот книги. [ОР РГБ. Ф. 210 № 4].

Тихон Макарьевский (1676-1682) - автор «Ключа разумения», призванного объяснить знаменную нотацию с помощью нотнолинейной и наоборот. Двоезнаменные рукописи обладали особой ценнностью как первые расшифровки знаменного пения, созданные в XVII в. Труд Тихона Макарьевского начинается изображением ключа, символизирующего познание премудрости. 
Ф. 210, № 4] была создана в середине XVIII в. Она содержит наиболее полную версию «Ключа». Эта рукопись была подарена князю Одоевскому в день его Ангела, 15 июля, 1866 г. Дм. Разумовским и является списком с одной из его рукописей и с книги, хранящейся в Петербурге в Публичной Библиотеке (из Библиотеки графа Ф. А. Толстова.).

Завершает раздел «Азбуки» Мусикийская грамматика Николая Дилецкого. «Мусикийская азбука парьтеснаго пения» середины XVIII в. [ОР РГБ Ф. 210, № 5] - известный музыкально-теоретический труд Николая Павловича Дилецкого (ок. 1630 - ок. 1690), крупного русского теоретика и талантливого композитора второй половины XVII в. «Мусикийская грамматика» - первый в истории учебник элементарной теории музыки (европейской традиции) на русском языке, в котором описывается ряд важных категорий гармонии: квинтовый круг и сольмизация. Книга представляет собой вторую, «Смоленскую» редакцию грамматики $1670 \mathrm{r}$.

Таким образом, в первом разделе собрания Одоевского представлены важнейшие музыкально-теоретические труды XVII в., отражающие как древнерусскую, так и европейскую певческие традиции.

Далее следуют сборники песнопений на крюковых нотах: рукописи середины XVII в. - третьей четверти XIX в.: Ирмологии, Октоихи, Обиходы, Праздники, Триоди постные и цветные (исключение - сборник № 6: Азбука, Обиход и др., в котором присутствуют и знаменная, и пятилинейная нотации); сборники песнопений двоезнаменные, в которых параллельно с крюковой записью кокиз и фит дается их перевод на пятилинейную нотную систему.

Интересна история приобретения «Ирмология двузнаменного (на линейных и крюковых нотах)» [ОР РГБ Ф. 210, № 17] $]^{1}$. В рукописи на Л. 1. - запись рукой Одоевского: «22 янв. 1866 заплатил за эту рукопись Андрею Ефимовичу Сорокину двадцать пять рублей сер. в Москве. 1866 г.». Об этой рукописи есть также упоминание в дневнике Одоевского от 27 февраля 1864 г.: «Во время обеда Сорокин привез мне двойной крюконотный Ирмологий времен Никона - но не продает злодей», — отмечал Одоевский [Князь Владимир Одоевский: 113]. Толь-

\footnotetext{
1 Ирмологий двузнаменный (на линейных и крюковых нотах). Последн. четв, XVII в. Нотация верхних строк пятилинейная квадратная, нижних - знаменная, с признаками, пометы только на первом листе. Фиты в разводах и без разводов. Текст истинноречный.
} 


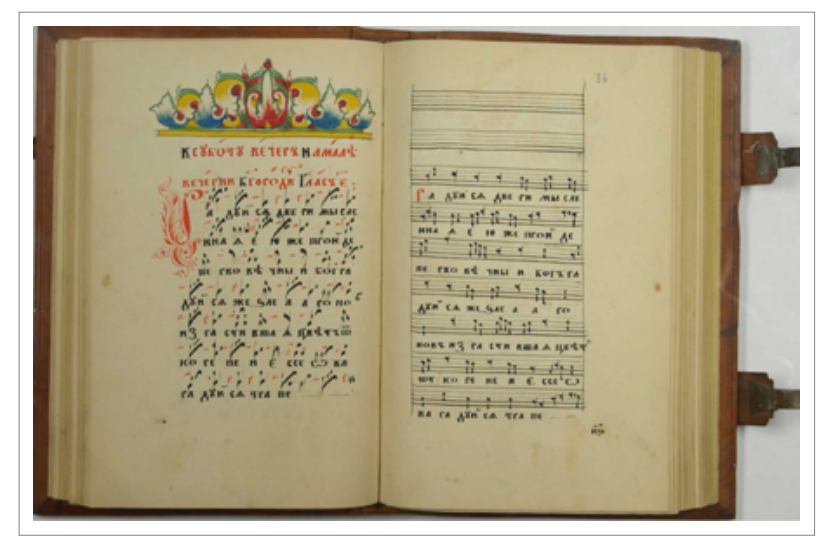

Октоих двузнаменный (на крюковых и линейных нотах). Середина ХІХ в. Полуустав. Переплет - доски в коже с тиснением. [ОР РГБ. Ф. 210 № 19].

ко через два года рукопись оказалась в собрании Одоевского, о чем также есть запись в дневнике: «Купил у Андрея Ефимовича Сорокина Ирмологий полный (двойной с крюками) в лист без конца и только на первом листе пометы - и заплатил 25 рублей серебром, насилу уговорил; он все хотел подарить мне да еще переплести» [Князь Владимир Одоевский: 156].

Также собрание включает сборники песнопений на линейных нотах, рукописи последней четвери XVII - третьей четверти XIX вв.: Ирмологии, Праздники - книги для пения в один голос (в унисон). «Сборник церковных песнопений на линейных нотах» [ОР РГБ Ф. 210, № 22] - список третьей четверти XIX в. с рукописи Оружейной палаты. Судя по владельческим записям, это копия с рукописной переплетенной в пергамент книги, на первом листе которой написано: «По сей книге (sic) петь изволил его императорское величество Петр Великий».

Рукописи для исполнения в несколько голосов (партесное пение) собрания датируются концом XVII в. - началом XVIII в. В этом разделе следует отметить «Праздники на линейных нотах. «Троестрочник». Первая четверть XVIII в. [ОР РГБ Ф. 210, № 24]. Этот сборник особенно важен, так как относится к числу многоголосных крюковых рукописей и является большой редкостью. С ним активно работал Одоевский, что подтверждается его записью на последнем листе (л. 132об.): «Предположение, что эти три партии когда-либо могли быть петы все вместе, 
одновременно не может даже возбуждать вопроса. Между ними нет никакого гармонического сопряжения; здесь явно партии вполне отдельных; никакое человеческое ухо не может вынести ряда секунд, что здесь на каждом шагу, да и характеры партий различные: путь (строка киноварная) вообще прост; верьх и низ весьма изукрашены; все три партии по месту, занимаемому нотами, пригнаны к местам, занимаемым словами, от того часто четверть одной партии стоит против нескольких четвертей и даже целых в другой - новое доказательство отдельности или самобытности каждой партии. Может существовать вопрос лишь о назначении каждой из сих партий. Верьх и низ явно напевы праздничные или назначенные для искусных певцов; тогда отличие их от пути понятно. Но какое различие в назначениях верьха и низа? К. В. Одоевский. Москва 1867».

Отдельного внимания заслуживает рукопись «Альбом по истории русского пения (и нотописания)» [ОР РГБ Ф. 210, № 31], включающий рукописи, печатный текст и фотокопии, и, видимо, задуманный Одоевским как хрестоматия по теории древнерусского певческого искусства. Рукопись содержит примеры различных видов нотаций, описания знамен, их перевод на линейную нотацию в наглядной форме и статьи о богослужебном пении.

В 1864 г. князь Одоевский стал одним из членов-основателей Общества древнерусского искусства, работавшего при Московском Публичном и Румянцевском музее [Вишневская: 100-105]. Деятельность его в Обществе была связана, прежде всего, с вопросами, касающимися древнерусского пения, направлена на восстановление исконных древнерусских певческих традиций, которые во многом были утрачены стремлением государства «унифицировать» формы церковного пения.

Одоевский был первым, кому пришла идея «в виду возросшего интереса по вопросам теоретических и практических сведений о древнерусском церковном пении, издать важнейшие руководства к этому предмету, а также лучшие образцы древнего пения» [Устав и протоколь общества древнерусского искусства: 31]. Из-за отсутствия необходимых типографских шрифтов он предложил воспользоваться для этой цели «открытыми им и представленными в Общество простыми элементами, на которые разлагаются древние нотные крюковые знаки, и при этом вызвался собрать и доставить Обществу предварительные сведения, чего будет стоить заготовление пунсонов и матриц для изда- 
ния древних нотных знаков по предложенному им способу» [Устав и протоколы общества древнерусского искусства: 31].

С его подачи Общество решило устроить духовный концерт, состоящий из произведений древнерусского церковного пения. Верный своему постоянному стремлению к просвещению, Одоевский предложил совместить этот концерт с публичными лекциями на эту же тему. В течение 1864-1865 гг. шла активная работа по подготовке к изданию певческих трудов на крюковых нотах. Одоевский много работал над методикой издания певческих азбук, и идея использования типографского шрифта для печати нотных крюков очень занимала его и его единомышленников.

Этот факт нашел отражение в собрании Одоевского. Рукопись «Проект двух пунктов протокола заседания Общества древнерусского искусства, составленный В. Ф. Одоевским» [ОР РГБ Ф. 210, № 34.3] имеет в виду следующие вопросы:

a) о представленных Яковом Онисимовичем Орлом-Ошмянцевым образцах «увеличенного шрифта для типографского набора крюков» (крюковых нотных знаков);

б) о фотографиях двух страниц «Ключа Тихона Макарьевского с рукописи «половины 17-го века», воспроизводящих песнопение для трехголосного хора.

По предложению Одоевского в члены Общества был избран секретарь Славянского комитета Яков Онисимович Орел-Ошмянцев - издатель труда Одоевского «Музыкальная грамота для не-музыкантов». Их совместные усилия увенчалась успехом, и на заседании Общества 25 апреля 1865 г. Одоевский продемонстрировал его членам образцы особых типографских знаков для печатания крюковых нот вместе с обычным текстом, подготовленные им совместно с Я. О. Орлом-Ошмянцевым. Создание типографского шрифта, позволявшего печатать нотные крюки, стало абсолютно новым изобретением в типографском деле.

7 марта 1865 г. Одоевский прочел на заседании Общества исследование Д. В. Разумовского о Тихоне Макарьевском, «сообщающее совершенно новые сведения об этом замечательном теоретике древней церковной музыки XVII в., и потом представил программу предполагаемого Обществом концерта славяно-русского духовного песнопения, в который могло бы войти следующее: 1) трехголосие из редчайшей рукописи Тихона Макарьевского первой половины 
XVII в.; 2) статьи из древнего песнопения по синодальному обиходу: киевского, греческого и знаменного распева; 3) статьи из литургии Сербов; 4) духовная песнь Славянина Петеля (известного на западе под именем Gallus, иначе Haenl) XVII в.; 5) духовные песнопения из Бортнянскаго, Турчанинова и Львова» [Устав и Протоколь Общества Древнерусского искусства: 36].

В этот период князь в поисках старинных книг совершал поездки в монастыри, в частности - в Троице-Сергиеву лавру, тщательно обследовал все московские библиотеки: Синодальную (Патриаршью), Синодальной типографии и Публичную. В его библиотеке сохранился указатель для обозрения Московской патриаршей (ныне синодальной) ризницы и библиотеки с дарственной надписью от автора, архиепископа Саввы.

Именно В. Ф. Одоевский стоял у истоков работ по исправлению нотных книг богослужебного пения. Также он настаивал на составлении новой азбуки нотного пения, которая обычно печатается вначале церковного обихода. Со своими предложениями он обратился к обер-прокурору Синода графу Д. А. Толстому. Предложения Одоевского были приняты к рассмотрению. «Святейший Синод с признательностью примет труд Ваш по сему предмету, если по рассмотрении составленной Вами азбуки сведущими людьми, она окажется вполне соответствующей цели» [Государственный центральный музей музыкальной культуры им. М. И. Глинки, ед. хр. 274, л.1 об.] - писал граф Д. А. Толстой Одоевскому. Этот масштабный проект был осуществлен уже после смерти В. Ф. Одоевского. 31 мая 1869 г. на заседании Общества древнерусского искусства было зачитано отношение обер-прокурора Святого Синода Д. А. Толстого от 15 мая с поручением Обществу учредить комиссию по данному вопросу. Д. В. Разумовский - исследователь древнерусского певческого искусства и друг Одоевского в течение последующих двадцати лет занимался исправлением нотных синодальных книг для нового их издания.

Благодаря усилиям Одоевского в Московской консерватории была создана кафедра русского церковного пения, в программу обучения которой вошли лекции по истории церковного пения. Их читал Д. В. Разумовский. После смерти Одоевского Дирекция Музыкального общества учредила при консерватории стипендию им. В. Ф. Одоевского, установленную на средства, завещанные его вдовой [Московская консерватория: материаль и документы: 36]. 
Задача возрождения традиций древнерусского знаменного пения, которую ставил перед собой Одоевский, чрезвычайно актуальна в XXI в. Это возрождение возможно именно в церковной среде путем практического применения опыта древнерусского певческого искусства в богослужебной практике, серьезного изучения опыта и правил, в том числе через обращение к наследию Одоевского и его рукописному собранию.

\section{Список литературы}

Архив Российской государственной библиотеки. Оп. 1. Ед. хр. 105. Л. 6-7.

Бражников М. В. Древнерусская теория музыки: по рукописным материалам XV - XVIII вв. Л.: Музыка, 1972. 421 с.

Вишневская Е. Э. В. Ф. Одоевский и Общество древнерусского искусства при Московском Публичном и Румянцевском музее в 1860-е гг. // Румянцевские чтения: Материалы межд. науч. конф. (16-17 апреля 2013). М: Пашков дом, 2013. C. $100-105$.

Государственный центральный музей музыкальной культуры им. М. И. Глинки. Ф. 73.

Князь Владимир Одоевский: дневник, переписка, материалы: к 200-летию со дня рождения. М.: Дека-ВС, 2005. 520 с.

Московская консерватория: материалы и документы из фондов МГК им. П. И. Чайковского и ГЦММК им. М. И. Глинки. М., 2006. Т. 1. 126 с.

Одоевский В. Ф. Заметка о пении в приходских церквах. М.: тип. Бахметева, 1864. $13 \mathrm{c}$.

Одоевский В. Ф. К вопросу о древнерусском песнопении. М.: тип. Бахметева, 1864. $27 \mathrm{c}$.

Одоевский В. Ф. Краткие заметки о характеристике русского церковного православного пения // Труды первого Археологического съезда в Москве. Т. І. М., 1869. $318 \mathrm{c}$.

Одоевский В. Ф. Мирская песня, написанная на восемь гласов крюками с киноварными пометами // Труды первого Археологического съезда в Москве. Т. II. М., 1871. C. $484-491$.

Одоевский В. Ф. Мнение князя В. Ф. Одоевского по вопросам, возбужденным Министерством народного просвещения по делу о церковном пении. М, 1866. 18 с.

Одоевский В. Ф. Музыкальная грамота для немузыкантов. М.: Я. С. Орел, 1868. $26 \mathrm{c}$.

Одоевский В. Ф. Музыкально-литературное наследие / общая редакция, вступительная статья и примечания Г. Б. Бернандта. М.: Музгиз, 1956. 723 с.

Одоевский В. Ф. Опыт о музыкальном языке. СПб.: в типографии III Отделения Собственной Е. И. В. канцелярии, 1833.21 с.

Одоевский В. Ф. Различие между ладами (Tonarten, tons) и гласами (Kirchentonarten, tonsd'eglise) // Труды первого Археологического съезда в Москве. T. I. M.: 1869. C. $481-484$. 
Одоевский В. Ф. Русская и так называемая общая музыка. М.: тип. газ. «Русский», 1867.35 c.

Одоевский В. Ф. Хорное пение в Исаакиевском Соборе. Спб.: тип. Имп. Акад. наук, 1858.6 с.

Одоевский В. Ф. Старинная песня // Русский Архив. 1863. С. 125-129.

ОР РГБ. Ф. 210.

Русская духовная музыка в документах и материалах: В 6 т. Т. 3 Церковное пение пореформенной России в осмыслении современников. М.: Языки славянской культуры, 2002. 903 с.

Собрание В. Ф. Одоевского. Ф. 210. М., 1960.

Устав и Протоколы Общества Древнерусского искусства при Московском Публичном музее. М.: Университет. тип., 1876. 163 с.

Шевцова О. Б. Наука о церковном пении в трудах князя В. Ф. Одоевского: опыт реконструкции: автореф. дисс. ... канд. искусств. М., 2012. 26 с.

\section{References}

Arkhiv Rossiiskoi gosudarstvennoi biblioteki [Archive of the Russian State Library]. Op. 1. Ed. khr. 105. L. 6-7. (In Russ.)

Brazhnikov M. V. Drevnerusskaia teoriia muzyki: po rukopisnym materialam XVXVIII $v v$. [Old Russian theory of music: based on manuscript materials of the XV-XVIII centuries]. Leningrad, Muzyka Publ., 1972. 421 p. (In Russ.)

Vishnevskaia E. E. V. F. Odoevskii i Obshchestvo drevnerusskogo iskusstva pri Moskovskom Publichnom i Rumiantsevskom muzee v 1860-e gg [V. F. Odoevsky and the Society of Old Russian Art at the Moscow Public and Rumyantsev Museum in the 1860s]. Rumiantsevskie chteniia: Materialy mezhd. nauch. konf. [Rumyantsev readings: Materials int. scientific conf]. Moscow, Pashkov dom Publ., 2013. pp. 100-105. (In Russ.)

Gosudarstvennyi tsentral'nyi muzei muzykal'noi kul'tury im. M. I. Glinki [The State Central Museum of Musical Culture named after M. I. Glinka]. F. 73. (In Russ.)

Kniaz' Vladimir Odoevskii: dnevnik, perepiska, materialy: $k$ 200-letiiu so dnia rozhdeniia [Prince Vladimir Odoevsky: diary, correspondence, materials: on the 200th anniversary of his birth]. Moscow, Deka-VS Publ., 2005. 520 p. (In Russ.)

Moskovskaia konservatoriia: materialy $i$ dokumenty iz fondov $M G K \mathrm{im}$. P. I. Chaikovskogo i GTsMMK im. M. I. Glinki [Moscow Conservatory: materials and documents from the funds of MGK im. P. I. Tchaikovsky and the State Central ScientificMetallurgical Plant named after M.I. Glinka]. Moscow, 2006. Vol. 1, 126 p. (In Russ.)

Odoevskii V. F. Zametka o penii v prikhodskikh tserkvakh [A note on singing in parish churches]. Moscow, tip. Bakhmeteva Publ, 1864. 13 p. (In Russ.)

Odoevskii V. F. K voprosu o drevnerusskom pesnopenii [To the Question of Old Russian Chant]. Moscow, tip. Bakhmeteva Publ, 1864. 27 p. (In Russ.)

Odoevskii V. F. Kratkie zametki o kharakteristike russkogo tserkovnogo pravoslavnogo peniia [Brief notes on the characterization of Russian Orthodox Church singing]. Trudy pervogo Arkheologicheskogo s"ezda v Moskve [Proceedings of the First Archaeological Congress in Moscow]. Vol. 1. Moscow, 1869. 318 p. (In Russ.) 
Odoevskii V. F. Mirskaia pesnia, napisannaia na vosem' glasov kriukami s kinovarnymi pometami [A song of peace written in eight voices with cinnabar-lit hooks]. Trudy pervogo Arkheologicheskogo s"ezda v Moskve. [Proceedings of the First Archaeological Congress in Moscow]. Vol. II. Moscow, 1871. pp. 484-491. (In Russ.)

Odoevskii V. F. Mnenie kniazia V. F. Odoevskogo po voprosam, vozbuzhdennym Ministerstvom narodnogo prosveshcheniia po delu o tserkovnom penii [Opinion of Prince V. F. Odoyevsky on issues brought by the Ministry of Education in the case of church singing]. Moscow, 1866. 18 p. (In Russ.)

Odoevskii V. F. Muzykalnaia gramota dlia nemuzykantov [Musical instrument for non-musicians]. Moscow, Ia. S. Orel Publ., 1868. 26 p. (In Russ.)

Odoevskii V. F. Muzykal'no-literaturnoe nasledie [Musical and literary heritage]. Obshchaia redaktsiia, vstupitel'naia stat'ia i primechaniia G. B. Bernandta [General edition, introductory article and notes by G. B. Bernandt]. Moscow, Muzgiz Publ, 1956. 723 p. (In Russ.)

Odoevskii V. F. Opyt o muzykal'nom iazyke [Experience about the musical language]. St. Petersburg: v tipografii III Otdeleniia Sobstvennoi E. I. V. kantseliarii Publ, 1833. 21 p. (In Russ.)

Odoevskii V. F. Razlichie mezhdu ladami (Tonarten, tons) i glasami (Kirchentonarten, tonsd'eglise) [The difference between frets (Tonarten, tons) and voices (Kirchentonarten, tonsd'eglise)]. Trudy pervogo Arkheologicheskogo s"ezda v Moskve [Proceedings of the first Archaeological Congress in Moscow]. Vol. 1. Moscow, 1869. P. 481-484. (In Russ.)

Odoevskii V. F. Russkaia i tak nazyvaemaia obshchaia muzyka [Russian and so-called general music]. Moscow: tip. gaz. Russkii' Publ, 1867. 35 p. (In Russ.)

Odoevskii V. F. Khornoe penie v Isaakievskom Sobore [Choir singing in St. Isaac's Cathedral]. St. Petersburg: tip. Imp. Akad. Nauk Publ, 1858. 6 p. (In Russ.)

Odoevskii V. F. Starinnaia pesnia [Old song]. Russkii Arkhiv [Russian Archive]. 1863. P. 125-129. (In Russ.)

OR RGB. F. 210. (In Russ.)

Russkaia dukhovnaia muzyka $v$ dokumentakh i materialakh [Russian sacred music in documents and materials]. In 6 vol. Vol. 3. Tserkovnoe penie poreformennoi Rossii v osmyslenii sovremennikov [Church singing of post-reform Russia in the understanding of contemporaries]. Moscow: Iazyki slavianskoi kul'tury Publ, 2002. 903 p. (In Russ.)

Sobranie V. F. Odoevskogo [The collection of V. F. Odoevsky]. F. 210. Moscow, 1960. (In Russ.)

Ustav i Protokoly Obshchestva Drevnerusskogo iskusstva pri Moskovskom Publichnom muzee [The Charter and Protocols of the Society of Old Russian Art at the Moscow Public Museum]. Moscow: Universitet. tip. Publ, 1876. 163 p. (In Russ.)

Shevtsova O. B. Nauka o tserkovnom penii v trudakh kniazia V. F. Odoevskogo: opyt rekonstruktsii [The science of church singing in the writings of Prince V. F. Odoevsky: the experience of reconstruction]: autoref. diss. ... cand. arts, Moscow, 2012. 26 p. (In Russ.) 


\section{(C) 2019. Н. Н. Вихрова \\ г. Великий Новгород, Россия}

\section{И. С. Аксаков о монастырях и монашестве (по материалам переписки с женой)}

Статья выполнена в рамках проекта «Письма А. Ф. Тютчевой (Аксаковой)

И. С. Аксакову (1865-1886): подготовка комментированного издания переписки» №18-012-00419 при финансовой поддержке РФФИ

Аннотация: Переписка И. С. Аксакова с женой является полноценным источником для характеристики его воззрений по самому широкому кругу вопросов. Поскольку оба корреспондента были глубоко верующими людьми, религиозная тематика и проблематика широко представлена в их эпистолярном наследии. Материалы переписки, в которых затрагиваются вопросы, касающиеся роли и значения института монашества, демонстрируют, что И. С. Аксаков приветствовал его несомненную духовно-просветительскую и даже государствообразующую роль в российской истории, однако официальное положение института монашества в синодальный период считал косным и не вполне соответствующим христианскому идеалу. Вместе с тем, супруги Аксаковы были единодушны в признании монастырей как традиционных центров средоточия истинной святости и духовного подвига отдельных личностей.

Ключевые слова: православие, монашество, монастырь, славянофильство, христианский идеал

Информация об авторе: Вихрова Нина Николаевна, кандидат филологических наук, доцент, Новгородский государственный университет им. Ярослава Мудрого, ул. Санкт-Петербургская, д. 41, 173003, г. Великий Новгород, Россия

E-mail: vihnn@mail.ru

Дата поступления статьи в редакиию: 27.10 .2019

Дата публикации статьи: 10.12.2019

Для иитирования: Вихрова Н. Н. И. С. Аксаков о монастырях и монашестве (по материалам переписки с женой) // Два века русской классики. 2019. Т. 1. № 2. C. 78-93. DOI 10.22455/2686-7494-2019-1-2-78-93 




This is an open access article distributed under the Creative

Commons Attribution 4.0

International (CC BY 4.0)

\title{
(C) 2019. Nina N. Vikhrova Veliky Novgorod, Russia
}

\section{S. Aksakov about monasteries and monasticism (on materials of the correspondence with his wife)}

\author{
Article is executed within work on project "Letters of A. F. Tyutcheva (Aksakova) to \\ I. S. Aksakov (1865-1886): preparation of the commented edition of correspondence" \\ №18-012-00419 with financial support of the RFBR
}

\begin{abstract}
I. S. Aksakov's correspondence with his wife is a full-fledged source for characterizing his views on the widest range of issues. Due to the fact that they were deeply and confidently religious people, religious themes and issues are widely represented in their epistolary heritage. The materials of correspondence, which are touching the issues about the role and significance of the institution of monasticism, demonstrates that I. Aksakov welcomed its undoubted spiritual and educational and even state-forming role in Russian history. But he considered its official position in the synodal period to be rigid and not quite in line with the Christian ideal. At the same time, the Aksakovs were unanimous in recognizing the monasteries as the traditional centers of the heart of true holiness and spiritual feat of individuals.
\end{abstract}

Keywords: Orthodoxy, monasticism, monastery, Slavophilism, Christian ideal

Information about the author: Nina N. Vikhrova, $\mathrm{PhD}$ in Philology, docent, Yaroslav-the-Wise Novgorod State University, B. St. Petersburgskaya, 41173003 Veliky Novgorod, Russia

E-mail: vihnn@mail.ru

Received: October 27, 2019

Published: December 10, 2019

For citation: Vikhrova N. N. I. S. Aksakov about monasteries and monasticism (on materials of the correspondence with his wife). Two centuries of the Russian classics, 2019, vol. 1, № 2, pp. 78-93. (In Russ.) DOI 10.22455/2686-7494-2019-1-2-78-93 
Представитель так называемых «младших» славянофилов И. С. Аксаков - заметное лицо в истории литературы и общественной мысли XIX в. Благодаря активной журналистской и публицистической деятельности в пореформенное время он стал широко известен в обществе как проводник либерально-консервативных взглядов, базирующихся на традиционных ценностях русского народа. Уже давно замечено, что богатое эпистолярное наследие И. С. Аксакова является полноценным источником для характеристики его воззрений на самый широкий круг вопросов, это, разумеется, распространяется, в частности, и на переписку Аксакова с женой.

И. С. Аксаков и А. Ф. Аксакова (Тютчева) были глубоко и убежденно верующими людьми. Религиозная тематика и проблематика, как и разного рода церковная фактология (сообщения о качестве церковных служб, богомолье в церквях и монастырях, о значимых днях православного церковного календаря, говении, панихидах, молебнах и пр.) можно сказать, пронизывает их переписку. Упоминание в переписке московских и петербургских монастырей (Симонов, Донской, Алексеевский, Новодевичий Смоленский в Москве, Новодевичий Воскресенский - в Санкт-Петербурге и др.) чаще всего связано с некрополями, с традицией монастырских семейных усыпальниц. Так, в Москве Аксаковы хоронили в отдаленном Симоновом монастыре (здесь в девятнадцатом столетии были похоронены отец, мать, братья и сестры, умершие при жизни И. С. Аксакова, кроме С. С. Аксаковой ${ }^{1}$ [РГАЛИ.

1 И. С. Аксаков, распоряжавшийся похоронами своей сестры, принял решение о погребении в Киеве на основании телеграммы жены, которая сообщала об отсутствии места в родовой усыпальнице: «Симоновский наместник бывший казначей уверяет что на вашем месте нет свободного места на внутрени около решетки был ли у Сони документ на приготовленную ей могилу если нет то прикажешь ли ей купить могилу в другой части кладбища около вас все занято Анна» (Орфография и пунктуация источника - H. В.). 
Ф. 10. Оп. 1. Ед. хр. 173. Л. 239], скончавшейся в 1885 г. и погребенной в Киево-Печерской Лавре возле Десятинной церкви у дальних пещер), Тютчевы - в Новодевичьем Смоленском монастыре (Аксаковы участвовали в погребении матери Ф. И. Тютчева - Екатерины Львовны, сестры - Д. И. Сушковой и ее мужа, дочери - Е. Ф. Тютчевой, умершей на руках А. Ф. Аксаковой). На страницах переписки довольно часто упоминаются скорбные события, связанные с похоронами и посещением могил близких людей: кроме Аксаковых и Тютчевых, М. П. Погодина, С. М. Соловьева, Н. В. Рукавишникова, Н. В. Путяты, Ю. Ф. Самарина, В. А. Елагина, Д. А. Оболенского и др. Сами корреспонденты последний приют обрели также в монастырской ограде Троице-Сергиевой лавры.

Иван Аксаков, с рождения впитавший в себя русскую православную культуру, и А. Ф. Тютчева, немка, приехавшая в Россию восемнадцатилетней девушкой, при всем их мировоззренческом единодушии, все же, думается, несколько по-разному должны были осмыслять реалии русской «исторической» церкви. А. Ф. Тютчеву в первую очередь занимала ее мистическая сторона. Православный монастырь, по ее мнению, - это средоточие святости и божественной благодати, где монахи исполняют духовное подвижничество в беспрестанной молитве за греховное человечество. Именно благодаря бескорыстности и искренности духовного служения монахов становятся благодатными места, где расположен монастырь, и чудотворными вещи, находящиеся в нем. В этой связи можно вспомнить рассказ А. Ф. Тютчевой в дневнике о чудотворной мантии Серафима Саровского, благодаря которой удалось в 1860 г. излечить от скарлатины Великую княжну Марию Александровну и облегчить предсмертные страдания императрицы Александры Федоровны, а также через год написанное стихотворение «Святые горы». Последнее произведение было исправлено Ф. И. Тютчевым, который несколько исказил идею дочери, сместив акцент с прославления молитвенного подвига на предвечный животрящий крест [Литературное наследство: 330-333]. Вместе с тем для А. Ф. Тютчевой святость места обуславливается в первую очередь святостью и нравственной чистой личности, осуществляющей духовное служение. Так, спустя три года после свадьбы А. Ф. Тютчева писала мужу: «’ai été à la messe au Kremlin. Il y a voit messe d’archevêque à Успенск pour la fête de St. Philippe. J’ai bien prié pour toi et cela ma rendu le coeur un peu plus tranquille. $<\ldots>$ Maman 
et Sophie étaient aussi à Успенск. Je me suis approchée avec maman des reliques de St. Philippe: c'est sur ces reliques que maman ma bénie après la messe le lendemain du jour où je suis devenue te promise. C'est aujourd'hui, fête de St. Philippe que je suis arrivée ici il y a sens pour me marier, c'est dans l'église de St. Philippe que notre mariage a été béni. Si nous avons un fils, Jean, il faut le nommer Philippe. Cétait un saint et un grand citoyen et un homme au coeur droit» [РГАЛИ. Ф. 10. Оп. 1. Ед. хр. 173. Л. 17-17 об.] $]^{1}$. Вообще А. Ф. Аксакова, при том, что имела критический склад ума, отличалась склонностью к мистицизму, верила в вещие сны и предзнаменования, причем И. Аксаков признавался, что он действительно знал за своей женой «эту грустную способность» [Аксаков, Письмо к А. Н. Бахметевой] предсказания бед. Эта особенность усугубилась после смерти Аксакова. С. Н. Маслова-Горбова вспоминала, как посетила А. Ф. Аксакову незадолго до ее смерти, когда она поселилась в Сергиевом Посаде, чтобы быть ближе к могиле мужа: «Пришел к завтраку какой-то монах. Разговор шел о мистиках, Юнг-Штиллинге и Сведенборге: Анна Федоровна искала возможности общения с душою Ивана Сергеевича, читала мистиков, занималась спиритизмом» [Маслова-Горбова]. Между тем, несмотря на то, что А. Ф. Аксакова искренно и горячо приняла православную веру со всем набором истинно «православного христианства», предложенного К. Н. Леонтьевым, «с верой в икону Иверской Божией Матери, в мощи св. Сергия, в проповеди Тихона Задонского и Филарета, в прозорливость и святую жизнь некоторых и ныне живущих монахов» [Фетисенко: 175], - ее непримиримый максимализм в отношении нарушения чистоты нравственного облика Божьих молитвенников свидетельствовал об элементах протестантской этики, лежащей в основе ее христианского идеала и заставлял яростно нападать на К. Н. Леонтьева, когда он не придавал должного значения «подлости»

\footnotetext{
1 Я ходила к обедне в кремль. В Успенском была архиерейская служба по случаю дня Св. Филиппа. Я хорошо помолилась за тебя, и на сердце стало немного тише. <...> Маменька и Соня тоже были в Успенском. Мы приложились с маменькой к мощам Св. Филиппа: именно при этих мощах маменька меня благословила после обедни на следующий день после того, как я стала твоей суженой. Именно сегодня, в день Святого Филиппа, я приехала сюда с намерением выйти замуж, именно в церкви Святого Филиппа наш брак был благословлен. Если у нас будет сын, Иван, мы должны его назвать Филипп. Это был и святой, и великий гражданин, и человек с честным сердцем ( $р$.) $($ перевод автора $-H$. B.)
} 


\section{Русская литература XVIII и XIX столетий

игуменьи Митрофании, подделывающей векселя [Фетисенко: 162]. При этом очернить в глазах Аксаковой святое место монастыря мог любой намек на казенность и духовную пустоту даже самых незначительных его насельников или суетность и пошлость мирян, ставящих материальное выше духовного. К примеру, такую характеристику дает Аксакова Воскресенскому Новодевичьему монастырю в Петербурге, где находилась усыпальница Тютчевых, а заодно Александро-Невской Лавре: «Nos tombes sont admirablement soignées avec de si beaux monuments et toutes couvertes de fleurs. Mais ce qui gate l'impression c'est d'avoir à faire à la religieuse qui soigne ces tombes, une vilaine creature avide qui vous enable de grossière flagornerie pour vous tirer de l'argent. On mademandé de quell prix je voulais la панихида. J'ai dit 3 rbls à tout hazard. On ne m’a crié qu'une litia. Daria m’a dit qu'une vraie панихида coûte 8 rbls, la messe 25 , enfin un pillage. J’ai encore donné 3 rbls à cette vilaine femme, чтоб откупиться de son insipide conversation. J'ai possé une demi heure seule près de ces tombes, toutes enveloppes de la poétique douleur de me belle mère. Un monde de souvenir m'a envahir. Si je meurs avant toi ne menterre pas près d'un convent ni d'hommes ni de femmes, ni dans une ville. Enterre moi à la campagne près de d'une église de village. C'est une hospitalité que je demanderai à Kitty. Je n’aime pas non plus ces grands mausolés plus durables que le fragile souvenir et la vie fragile de eux qui nous survivent et qui nous pleurent. Rien n'triste comme ces monumens pour peux de souvenir changes en monumens d'oubli. Mille fois mieux vaut laìsser la nature jeter sur nos cendres le voile poètique don't elle recouvre tout ce quelle reprend dans son sein. C'est la réflexion que j'ai faite plus tard sur la tombe d'Eugenie ${ }^{1}$ qui est on couvent de Nefsky de Lazare le plus vieux couvent de Petersburg, et qui a l'aspect lugubre d'une vieille carrière de pierres vermoulues, suintant l'humidité et se couvrant avec peine d'une mousse verdâtre» [РГАЛИ. Ф. 10. Оп. 1. Ед.хр. 173. Л. 131-132]². Впрочем, кажется, что негативный тон

\footnotetext{
1 Речь идет о Е. С. Шеншиной (1833-1873), близкой подруге А. Ф. Аксаковой, родной сестре воспитателя великих князей - Д. С. Арсеньева.

2 Наши могилы хорошо ухожены, с красивыми памятниками и все покрыты цветами. Но что портит впечатление, так это то, что вам нужно видеть монахиню, которая следит за этими могилами, уродливое, жадное существо, которое раздражает вас грубым подхалимажем, чтобы вытащить из вас деньги. Меня спросили, за какую цену я желала бы заказать панихиду. Я сказала наудачу, что за 3 руб. Мне стали кричать, что это только лития. Дарья мне говорит, что в действительности панихида
} 
в отношении петербургских монастырей имеет еще идеологическую, славянофильскую подоплеку. Известно, как славянофилы, в том числе И. С. Аксаков, относились к петербургскому периоду русской истории, считая его подражательно-западническим, чуждым естественной органической жизни России, а значит - исторически ошибочным. В этом плане даже монастыри воспринимались как атрибут противоестественно созданной Петром столицы, города с «немецким» именем, в котором сидит «немецкое» правительство [Вихрова: 485-489]. А. Ф. Аксакова, которая провела в столице при дворе «12 лет противоестественной жизни» [РГАЛИ. Ф. 10. Оп. 1. Ед. хр. 236. Л. 256], разделяла нелюбовь мужа к этому городу. И. С. Аксакова, например, восхитило eе «сравнение Петербурга с courtisane» ${ }^{1}$, которое он посчитал «метким и удачным» [РГАЛИ. Ф. 10. Оп. 1. Ед. хр. 236. Л. 19].

Вместе с тем И. С. Аксаков, как славянофил, пытаясь понять историческое значение России, приходил к однозначному утверждению: «Нам не на что указать в старине - кроме молитвенных подвигов, не на кого - ни на одного государственного человека - кроме молитвенников, святителей, святых, затворников, пустынников, - ни на один памятник, кроме пещер, храмов, монастырей... богатое духовное наследие. Но что же мы с ним делаем? Мы не отказались от жизни, мы хотим и процветать, как все люди, но, не умея справиться с этим насле-

стоит 8 руб., обедня в довершение грабежа 25. Я дала еще 3 руб. этой гадкой женщине, чтобы откупиться от ее пошлого разговора. Я провела полчаса возле этих могил, полностью окутанных поэтическим страданием моей мачехи. Мир воспоминаний захватил меня. Если я умру раньше тебя, то не хорони меня рядом с монастырем, ни мужским, ни женским, ни в городе. Похорони меня в деревне рядом с деревенской церковью. Этого убежища я попрошу и у Китти. Мне также не нравятся эти огромные мавзолеи, более прочные, чем хрупкие воспоминания и хрупкая жизнь тех, кто нас переживет и оплачет. Нет ничего печальнее, чем эти монументы для воспоминаний, замененные на монументальное забвение. В тысячу раз лучше оставить природе покрывать наш прах поэтической завесой, которой она покрывает все, что берет обратно в свое чрево. Это размышление, которое я сделала позже на могиле Евгении, которая располагается в Невском монастыре у Лазаря, это старейший петербургский монастырь и имеет мрачный вид старой каменоломни из гнилых камней, сочащихся влагой и едва покрытых зеленоватым мхом (фр.) (перевод автора - Н. В.)

${ }^{1}$ Куртизанка (фp.). 
дием, отрекаемся от него и являемся действительно comme des bâtards ${ }^{1}$ в цивилизованном человечестве. Разрешит ли наконец себе Россия задачу - примирить духовное наследие с жизнью цивилизованною, или осуждена - однажды усомнившись в вере - явиться несамостоятельною и для жизни цивилизованной?» [И. С. Аксаков в его письмах: 277]. Действительно, при описании старинных монастырей у И. С. Аксакова всегда присутствует мысль о прошлом, связанном с настоящим. Так, подробно описывая невесте торжества в Киево-Печерской Лавре 15 июля 1865 г., в день Св. князя Владимира, И.С. Аксаков восклицает: «Вся родная история ожила во мне в ее непрерывной связи исторических мгновений или моментов, в ее живой, неумирающей связи, при ощущении которой утрачивается ощущение лет и времен. Что значит тысячелетие?! Дело Владимира будто вчерашнее дело; и переживаешь лично, в данную минуту, по-видимому, ограниченное условиями места и времени, - мгновение всемирно-историческое, касающееся племен и народов, миллионы миллионов лиц, преемственно сменявших друг друга в течение тысячелетия» [И.С. Аксаков в его письмах: 328]. Далее И. С. Аксаков весьма пространно размышляет о значении для Руси крещения, о преемственности и в то же время противостоянии Киева и Москвы, которые «выражают собою два момента в русской истории»: «В Москве Русь является государством и государственный элемент преобладающим, а в ощущении государственной силы есть что-то давящее и гнетущее. В Киеве же вам дышится так легко, как дышится в молодости, весною, утром! Идея единства только носилась над русскою землею, жила в общем сознании, но не воплощалась в резко осязательном факте единодержавия!.. А потом эти горы - полные пещер, и пещеры, полные этих “молитвенников за Русскую землю", - этой первой жатвы христианского посева» [И.С. Аксаков в его письмах: 330].

Через несколько лет И. С. Аксаков, посылая из Киева письмо от 18 октября 1877 г. жене, еще раз вернется к объяснению значения Киевской лавры и вновь проведет параллель с современностью, с горечью констатируя упадок интереса молодежи к источникам духовности: «Лавра - интереснейшее явление. Не можешь не сознавать, что вся она анахронизм, что она осуждена судом времени, что этот оазис X века среди XIX-го, уже теперь значительно поблекший, непременно поблекнет в XX; в то же время так хорошо, что среди этой современной

\footnotetext{
${ }^{1}$ Как незаконнорожденные ( $\left.ф р.\right)$
} 
банальной цивилизации, среди этого наплыва утилитаризма, - еще стоит этот каменный протест во имя высших требований духа, - этот свидетель, этот глашатай об иных запросах, о заботе не о хлебе едином. Но он уже не в состоянии сам по себе дать ответ современным мучительным допрашиваниям, удовлетворить голос людей нашего века. Не Лаврою можно ответить этим 200 нигилистам, о которых так не кстати [начинается] на днях суд в Петербурге» [РГАЛИ. Ф. 10. Оп. 1. Ед. хр. 235. Л. 15] ${ }^{1}$. Вместе с тем И. С. Аксаков для себя лично не мыслил иного поведения в монастыре, как традиционного: «Завтра я ударюсь во все тяжкие. Пойду к обедне, приложусь к образу, зайду к отцу Агапиту, к митрополиту Фелофею, - может быть, съезжу в Выдубицкий монастырь...» [РГАЛИ. Ф. 10. Оп. 1. Ед. хр. 235. Л. 15]. Вообще И. С. Аксаков, в отличие от жены, не был склонен к особой экзальтированности. Он, с одной стороны, с иронией относился к народной вере в «матушку» Иверскую икону [РГАЛИ. Ф. 10. Оп. 1. Ед. хр. 235. Л. 133], содрогался услужливости киевских монахов, предлагающих «стружек от мощей» [Аксаков И. С. Письма к родным: 256], признавался, что не любит «тот culte Богородицы, который существует в русском быту и отчасти в церкви» [И.С. Аксаков в его письмах: 325], с другой стороны, с удовольствием в многочисленных поездках по России посещал монастыри и церкви, прикладывался к мощам и чудотворным иконам, участвовал в молебнах, посылал освященные образки родным, имел множество хороших знакомых среди священников и монахов. И. С. Аксаков был убежден, что «велико значение монастырей, хранящих подле суетливой жизни идеал другой, совершеннейшей жизни, строгой тишины, неизменимо-ровное течение дней», но при этом повторял, что «не для монастырей и пустынь только явилось христианство» [Аксаков И.С. Письма к родным: 46]. Речь здесь, конечно, идет о понимании Аксаковым христианского идеала в широком смысле.

В славянофильской идеологии именно христианский идеал выступал и целью нравственного самосовершенствования, и тем универсальным критерием, с помощью которого проверялась истинность,

\footnotetext{
1 Имеется в виду «Процесс ста девяноста трёх» (официальное название - «Дело о пропаганде в Империи») - судебное дело революционеров-народников, разбиравшееся в Петербурге в Особом присутствии Правительствующего сената с 18 (30) октября 1877 по 23 января (4 февраля) 1878 г.. К суду были привлечены участники «хождения в народ», которые были арестованы за революционную пропаганду с 1873 гг.
} 
правомерность и значимость личного и социально-политического жизнестроительства, в том числе и церковного. Христианский идеал в понимании И. С. Аксакова сочетал в себе гармоническое единство «закона и благодати»: признание установлений и догматов православной церкви, святости совершаемых в ней таинств, уважение к сану священника и свободы совести, личного нравственного самосовершенствования, «действие живых, личных сил человеческой души» [Фетисенко: 160]. Вместе с тем, если, по определению Хомякова, церковь живых и мертвых, изначально единая, святая, безгрешная - это явление вневременное, то ее историческая ипостась создается людьми, которые в гордом стремлении своим разумением сохранить букву закона могут уклониться с пути любви, которая выражается в «деле, молитве и песне духовной» [Хомяков: 21]. Это может привести к оскудению благодати в такой церкви. Поэтому И. С. Аксаков допускал правомерной и полезной острую критику «исторической церкви» и ее «архиереев», высшего духовенства, которое, по сложившемуся обычаю, непременно должно быть из черного монашества. Последнее обстоятельство наводило на мысль, что монашеский постриг обусловлен не столько духовным подвигом, сколько карьерой. Осенью 1865 г. И. С. Аксаков опубликовал в «Дне» статью «Связь современного положения у нас монашества с вопросом об улучшении быта нашего православного духовенства» [ZZZ. (Ростиславов Д. И.)], в которой автор последовательно аргументировал положение, что «монашество из подвижничества стало карьерою» и предлагал пути исправления подобной ситуации. Аксакову импонировала острота затрагиваемых автором проблем черного и белого духовенства, и он подчеркивал, что статья, о которой он несколько раз весьма лестно упоминает в переписке с невестой, вполне соответствует духу его общественно-политической позиции: «Какая статья раздражит, так это статья о монашестве - раздражит всех архиереев. Она писана монахом очень дельно, обдуманно, тяжеловесно. Бесятся на меня архиереи, дворяне, Синод, Долгорукие, Валуевы. Ничего! Это очень приятно» [РГАЛИ. Ф. 10. Оп. 1. Ед. хр. 236. Л. 143]. Автор статьи, размышляя о том, почему тормозятся все реформы, которые призваны улучшить жизнь православного духовенства в России, называет «чрезвычайно важное обстоятельство», согласно которому «в statu quo духовенства все истекает из того положения, какое среди его занимает монашество, сосредоточившее у нас в своих руках и главное 
руководство воспитания будущих служителей церкви, и верховную правительственную власть над лицами, посвятившими себя на столь высокое служение - и вследствие сего упускают из виду, что всякое преобразование в быту православного духовенства тогда только может быть приведено к успешному окончанию, когда наперед будет предпослана ему реформа монашества. Само собою понятно, что здесь разуметь должно реформу, основанную не на одних только чисто теоретических соображениях, а на точном знакомстве как с основною мыслью монашества, так и с тем, в какой мере эта мысль осуществлялась на деле самыми светлыми личностями в иноческом быту, равно и на правильной оценке исторических событий, содействовавших приведению монашеского духовенства в то положение, в котором оно ныне находится» [ZZZ. (Ростиславов Д. И.)]. С точки зрения автора, чтобы исправить ситуацию, следует помнить основную цель, ради которой возникали иноческие общины, - служение Богу и человечеству. В современном мире, согласно мнению автора, наблюдается искажение этой цели, так как высшие чины церковной иерархии почти исключительно выходят из черного духовенства, и власть церковная, в силу органической близости к власти светской, становится одной из составляющей государственной машины. Если использовать терминологию Аксакова, то можно сказать, что монах превращался в «церковника». Выход был один - вернуть монашеству его основную функцию, запретить занимать монахам епископские места, все привлеченные в монастыри богатства тратить исключительно на благотворительность: «Мы не обязываем наших иноков ни к столь строго подвижнической жизни, какую вели монахи египетские, ни к преимущественному занятию выспренним созерцанием, - и то, и другое может быть у нас только исключительным явлением, а не общим правилом. Зато мы требуем от них, чтобы они чрез деятельное участие в делах общественной благотворительности больше, чем даже восточные монахи, совершали подвигов христианской любви к ближним» [ZZZ. (Ростиславов Д. И.)]. Кроме этого, автор предлагает «положить конец существованию у нас ученого монашества, как такового явления в иноческом нашем быту, которое вовсе ему не сродно, и притом введено у нас по подражанию нашим непримиримым врагам». «Впрочем, - уточняет автор статьи, - мы считаем нашим долгом здесь заметить, что мы при этом не имеем в виду обречь лиц монашествующих на крайнее невежество. 
Напротив, мы вполне уверены, что образование для них совершенно необходимо - даже мы готовы согласиться и на то, чтобы люди ученые попоступлении в монашество, продолжали свои учено-кабинетные занятия и в новом положении. Но допустить существование учено-монашеского общества с образовательно-воспитательною целью, тем более вверить ему воспитание будущих служителей церкви, мы ни под каким условием не можем» [ZZZ. (Ростиславов Д. И.)]. Причины столь негативного отношения автора к обществу ученых монахов очевидны: во-первых, невозможно воспитать свободную, творчески мыслящую личность монаху, основу существования которого составляет строгое послушание, и, во-вторых, образцом для российских обществ ученых монахов является орден иезуитов, или, как говорит автор, «в институт наших ученых монахов вкралась некоторая доля иезуитизма». Интересно, что критике ордена иезуитов будет посвящено несколько статей Ю. Самарина, опубликованные чуть позже в «Дне».

Еще в начале 1850-х гг. под впечатлением проповедей протестантского пастора Александра Вине, с одной стороны, и знакомства с святоотеческими творениями, с другой, И. С. Аксаков задумывается над вопросом о возможности совмещения личного счастья, аскетического подвига и общественного служения. Как известно, Хомяков в целом одобрил позицию И. С. Аксакова, защищающего для христианина право и на счастье, и на общественный подвиг, поскольку труд на благо ближнего - это высшая форма христианской молитвы и аскезы [Хондзинский П., прот: 169-170].

Основные положения, отраженные в переписке И. С. Аксакова с Хомяковым по поводу аскезы и личного счастья, Аксаков будет впоследствии разъяснять невесте, А. Ф. Тютчевой, рассуждая о таинстве брака и семейной любви. П. Хондзинский, оценивая негативное отношение Хомякова к христианской аскетике, писал: «Как бы то ни было, очевидно, что не менее скептически, чем к богословской школе (“Макарий провонял схоластикой”), Хомяков относился и к традиционной “монашеской” аскетике, зафиксированной традицией “Добротолюбия”, что естественно вытекало из его (и его друзей, за исключением Киреевского) отрицательного отношения к монашеству в целом» [Хондзинский П., прот: 171].

Так и И. С. Аксаков, утверждая высокий нравственный идеал в семейной жизни, призывает не поддаваться лжи «буквального» аскетиз- 
ма, проповедуемого некоторыми монахами (например, о. Матвея, духовника Гоголя), которые впадают в соблазн быть «духовнее Христа», поскольку в этом случае попирается свобода человека: «Мы можем впасть в страшную ложь - в ложь аскетов, если мы живую нашу душу будем сознательно, следовательно, искусственно и насильственно, так сказать, вытягивать в бесплотный дух, убивать в себе все живые в нас чувства. Для Ефрема Сирина и ему подобных - собственно говоря, Христос не довольно духовен, они хотят быть духовнее Христа, - этого “Сына человеческого, который ест и пьет” и радость брака освящает!» [РГАЛИ. Ф. 10. Оп. 1. Ед. хр. 236. Л. 194]. Утверждение это последовало в ответ на реплику А. Ф. Тютчевой о возможности такой любви между супругами, чтобы они могли радоваться смерти друг друга. И. С. Аксаков остроумно развенчал это ложное умозаключение: «Эдак, пожалуй, из любви к мужу, из прекрасного желания переселить его в радость духовную, - можно пособить ему, так, слегка, поскорее туда отправиться!» [РГАЛИ. Ф. 10. Оп. 1. Ед. хр. 236. Л. 195]. Думается, И. С. Аксаков смог убедить свою невесту в фальши «буквального» аскетизма, и в этой связи понятна ее реакция на брошюру монашествующего К. Леонтьева «Наши новые христиане» (1882): «Не столько атеисты - враги Христа, столько такие лица, как Вы, которые неправильным толкованием его слов компрометируют христианство» и вердикт И. С. Аксакова в отношении «аскетического миросозерцания» Леонтьева: «Его художественный талант не искупает кривизны его мысли, способной оправдывать фанариотов, даже иезуитов. Он не столько христианин, сколько церковник» [Фетисенко: 162]. Аксаков, не будучи «защитником монашества» [Аксаков, 1886: 348],уже в конце своей жизни писал в работе по поводу статьи неизвестного автора, скорее всего, толстовца, «Христианство и прогресс», о том, что он понимает историческую обусловленность монашества, искренность мотивации конкретных монахов и духовную сущность аскетизма: «Аскетизм есть прирожденная духу потребность - освободить дух от рабства телу. Без сомнения, он ложен, когда переходит в гордость духа и в презрение к телу или признает себя единственным путем спасения. Но никогда никакими соборными уставами церковь не выражала такого мнения. Даже на Западе целибат установлен для служителей церкви не как условие спасения, а как такое состояние, при котором человек удобнее может отдаться весь своему служению. Стремление к созданию монастырских общин 


\section{Русская литература XVIII и XIX столетий \\ Н. Н. Вихрова. И. С. Аксаков о монастырях и монашестве}

понятно с прекращением апостольских замкнутых общин. В апостольской общине члены состояли вне остального языческого мира. Когда общины разомкнулись и слились с миром полухристианским, полуязыческим, - потребность замкнутости ухода из мира выразилась в учреждении монастырей. Это явление временное - и уже пережившее или переживающее себя. Главное зло здесь, как и в большей части явлений, с церковью связанных, - это вмешательство государственного закона, который возвел, например, у нас, монахов в сословие, преследует за нарушение обета и проч., и проч.» [Аксаков, 1886: 356-357].

Таким образом, И. С. Аксаков и его жена осмысляли феномен монашества в России в рамках широко понимаемого христианского идеала. При этом они единодушно приветствовали монашеский подвиг как проявление искреннего, свободного и сугубо бескорыстного служения отдельного индивида и в то же время оставляли за собой право критиковать институт монашества, если видели в нем отступление от христианского идеала. Вместе с тем А. Ф. Аксакова, оставаясь во всех сферах духовной жизни в границах исторической церкви, критику распространяла только на явные факты личного несовершенства отдельных монахов, а И. С. Аксаков, как лидер славянофильства, мыслил своей задачей сформировать в обществе такой уровень национального самосознания, который бы обусловил наиболее органичные формы во всех сферах, в том числе и духовной жизни. Официальное положение института монашества в синодальный период он считал косным, слишком зависимым от «кесареви» и не вполне соответствующим историческому идеалу иноческой жизни, поэтому его критика иногда могла показаться церковным властям излишне радикальной, однако, в виду его высокой личной нравственности, мало кто сомневался в искренности его христианского служения обществу.

\section{Список литературы}

Аксаков И. С. Письмо к А. Н. Бахметевой // ИРЛИ. Ф. 3. Оп. 2. Ед. хр. 5.

Аксаков И. С. Полное собрание сочинений. Т. 4. М.: Типография М. Г. Волчанинова, 1886.770 с.

Аксаков И. С. Письма к А. Ф. Аксаковой 1865-1866 гг. // РГАЛИ. Ф. 10. Оп. 1. Ед. хр. 236.

Аксаков И. С. Письма к А. Ф. Аксаковой 1866-1886 гг. // РГАЛИ. Ф. 10. Оп. 1. Ед. хр. 235. 
Аксаков И. С. Письма к родным. 1848-1856 / Изд. подг. Т. Ф. Пирожкова. М.: Наука, 1994. 405 c.

Аксакова А. Ф. Письма к И. С. Аксакову 1866-1886 гг. // РГАЛИ. Ф. 10. Оп. 1. Ед. хр. 173.

Вихрова Н. Н. Псевдонимы И. С. Аксакова в газете «День» (1861-1865) // Ономастика Поволжья. Материалы XVII Международной научной конференции / Сост. и ред. В. Л. Васильев. 2019. С. 485-489.

И. С. Аксаков в его письмах. Эпистолярный дневник 1838-1886 гг. с предисловием, комментариями и воспоминаниями А. Ф. Аксаковой: в 3 тт. Т. III. Письма 1857-1886 гг. / сост., подг. текста, примеч. Т. Ф. Прокоповича. М.: «Русская книга», 2004. 608 c.

Литературное наследство. Т. 97. Федор Иванович Тютчев. Кн. 2 / АН СССР. Ин-т мировой лит. им. А. М. Горького; Отв. ред. С. А. Макашин, К. В. Пигарев, Т. Г. Динесман. М.: Наука, 1989. 711 с.

Маслова-Горбова С. Н. Воспоминания. [Электронный ресурс]. URL: https:// maslodmemoirs.wordpress.com/ (Дата обращения: 07.10.2019).

РГАЛИ. Ф. 10. ОП. 1. Ед. хр. 173. Л. 131-132.

Фетисенко О. Л. «Гептастилисты»: Константин Леонтьев, его собеседники и ученики: (Идеи русского консерватизма в литературно-художественных и публицистических практиках второй половины XIX - первой четверти XX века). СПб.: Издательство «Пушкинский Дом», 2012. 786 с.

Хомяков А. С. Сочинения в 2 тт. / Сост. В. А. Кошелева. Т. 2. Работы по богословию. М.: Медиум, 1994. 478 с.

Хондзинский П., прот. «Церковь не есть академия»: Русское внеакадемическое богословие ХІХ века. М.: Изд-во ПСТГУ, 2017. 480 с.

ZZZ. (Ростиславов Д. И.?) Связь современного положения у нас монашества с вопросом об улучшении быта нашего православного духовенства // День. 7 октября. № 35; С. $830-835 ; 9$ октября. № 36. С. 855-862.

\section{References}

Aksakov I. S. Pis'mo k A. N. Bahmetevoj [The letter to A. N. Bahmeteva]. Department of manuscripts of Institute of Russian literature. F. 3. Op. 2. Ed. hr. 5. (In Russ.)

Aksakov I. S. Polnoe sobranie sochinenij [The complete works]. Vol. 4. Moscow, Tipografiya M. G. Volchaninova Publ, 1886. 770 p. (In Russ.)

Aksakov I. S. Pis'ma k A. F. Aksakovoj 1865-1866 gg [The letters to A. F. Aksakova (1856-1866)]. The Russian State Archive of Literature and Arts. F. 10. Op. 1.Ed. hr. 236. (In Russ.)

Aksakov I. S. Pis'ma k A. F. Aksakovoj 1866-1886 gg [The letters to A. F. Aksakova (1866-1886)]. The Russian State Archive of Literature and Arts. F. 10. Op. 1. Ed. hr. 235. (In Russ.)

Aksakov I. S. Pis'ma $k$ rodnym.1848-1856 [The letters to Aksakov's family (18481856)]. Moscow, Nauka Publ, 1994. 405 p. (In Russ.) 
Aksakova A. F. Pis'ma k I. S. Aksakovu 1866-1886 gg. [The letters to I. S. Aksakov (1866-1886)] The Russian State Archive of Literature and Arts. F. 10. Op. 1. Ed. hr. 173. (In Russ.)

Vihrova N. N. Psevdonimy I. S. Aksakova v gazete "Den"' (1861-1865) [Pseudonyms of I. S. Aksakov in the journal "Den"” (1861-1865)]. Onomastika Povolzh'ya. Materialy XVII Mezhdunarodnoj nauchnoj konferencii [Onomastics of the Volga region. Materials of the XVII International Scientific Conference]. 2019. P. 485-489. (In Russ.)

I. S. Aksakov v ego pis'mah. Epistolyarnyj dnevnik 1838-1886 gg. S predisloviem, kommentariyami i vospominaniyami A. F. Aksakovoj: $v 3$ tomah. [I. S. Aksakov in his letters. The Epistolary Diary (1838-1886) with the foreword, commentaries and memories of A. F. Aksakova: in 3 vols]. Vol. III. Pis'ma 1857-1886. Moscow: Russkaya kniga Publ, 2004. 608 p. (In Russ.)

Literaturnoe nasledstvo. [The Literary Legacy] T. 97. Fedor Ivanovich Tyutchev. Moscow: Nauka Publ, 1989. 711 p. (In Russ.)

Maslova-Gorbova S. N. Vospominaniya [The Memories]. URL: https:// maslodmemoirs.wordpress.com/ (access date 7.09.2019) (In Russ.)

Fetisenko O. L. "Geptalisty": Konstantin Leont'ev, ego sobesedniki I ucheniki: (Idei russkogo konservatizma $v$ literaturno-hudozhestvennyh I publicisticheskih praktikah vtoroj poloviny XIX - pervo jchetverti XX veka). ["Geptalisty": Konstantin Leontiev, his interlocutors and students: (The ideas of Russian conservatism in the literary, artistic and journalistic practices of the second half of the XIX — the first quarter of the XX century)] St. Petersburg: Pushkinskij Dom Publ., 2012. 786 p. (In Russ.)

Homyakov A. S. Sochineniya $v 2$ tomah [Works in two volumes]. Sost. V. A. Kosheleva. Vol. 2. Moscow: Medium Publ, 1994. 478 p. (In Russ.)

Hondzinskij P., prot. "Cerkov' ne est' akademiya": Russkoe vneakademicheskoe bogoslovie XIX veka. ["The Church is not an Academy": Russian extra-academic theology of the 19th century.] Moscow: Publishing PSTGU, 2017. 480 p. (In Russ.)

ZZZ. (Rostislavov D.I.?) Svyaz' sovremennogo polozheniya $u$ nas monashestva $s$ voprosom ob uluchsheni byta nashego pravoslavnogo duhovenstva [The connection of the current situation of our monasticism with the question of improving the life of our Orthodox clergy]. Den'. 7 oktyabrya. № 35; P. 830-835; 9 oktyabrya. № 36 . P. 855-862. (In Russ.) 


\title{
Четыре Лавры: монастырская тема в художественном, публицистическом и эпистолярном наследии Кохановской (Н. С. Соханской)
}

\begin{abstract}
Аннотация: В статье анализируются взгляды и убеждения писательницы Надежды Степановны Соханской, работавшей под псевдонимом Кохановская. Автор статьи указывает два направления в творчестве Соханской: увековечение старинных произведений, преданий, а также наблюдение за сиюминутными, современными сценами, в которых в наибольшей степени проявляется национальное самосознание, духовный опыт народа. Центральное внимание в работе уделяется монастырской теме в творчестве Соханской. Автор статьи констатирует, что на раннем этапе писательница почти не затрагивала монастырскую тему, а позднее, в период сближения со славянофилами, осмысления значения веры и Церкви, Соханская не просто чаще начала обращаться к христианским образам, она стала организовывать свою жизнь таким образом, что ключевые вехи ее пути соотносились с посещением монастырей. Анализируя образы четырех Лавр (Киево-Печерской, Троице-Сергиевой, Александро-Невской и Почаевской) в художественных произведениях писательницы, ее публицистике и письмах, автор приходит к выводу о полном отсутствии дидактизма у Соханской, осознавшей особую роль монастырей, оказывающих людям помощь в мирской жизни и приносящих им утверждение в вере. В приложении к статье впервые публикуются ценные отрывки писем Соханской, передающие впечатления писательницы от красоты русских монастырей и прославляющие их.
\end{abstract}

Ключевые слова: Н. С. Соханская, Кохановская, монастыри, монастырский топос, Лавры, церковная тематика, православие, славянофильство

Информация об авторе: Фетисенко Ольга Леонидовна, доктор филологических наук, ведущий научный сотрудник, Институт русской литературы (Пушкинский Дом) Российской академии наук, наб. Макарова, д. 4, 199034, г. Санкт-Петербург, Россия

E-mail: betsy98@mail.ru

Дата поступления статьи в редакиию: 14.10 .2019

Дата публикации статьи: 10.12.2019

Для изтирования: Фетисенко О. Л. Четыре Лавры: монастырская тема в художественном, публицистическом и эпистолярном наследии Кохановской (Н. С. Соханской) // Два века русской классики. 2019. Т. 1. № 2. С. 94-109. DOI 10.22455/2686-7494-2019-1-2-94-109 


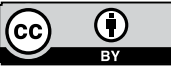

This is an open access article distributed under the Creative

Commons Attribution 4.0

International (CC BY 4.0)

\title{
Four Laurels: a monastic theme in the artistic, journalistic and epistolary heritage of Kokhanovskaya (N. S. Sokhanskaya)
}

\begin{abstract}
The article analyzes the views and beliefs of the writer Nadezhda Stepanovna Sokhanskaya, who worked under the pseudonym Kokhanovskaya. The author of the article points out two directions in the work of Sokhanskaya: the perpetuation of ancient works, traditions, as well as the monitoring of momentary, modern scenes which are most evidently show national identity, spiritual experience of the people. The main attention in the work is given to the monastery theme in the work of Sokhanskaya. The author of the article states that at the early stage the writer almost touched on the monastery theme, and later, during the rapprochement with the Slavophiles, the understanding of the meaning of faith and the Church, Sokhanskaya not only more often began to turn to Christian images, she began to organize her life in such a way that key milestones of her paths were related to visiting monasteries. Analyzing the images of the four Lavra (Kiev-Pechersk, TrinitySergius, Alexander Nevsky and Pochaev) in the writer's literary works, her journalism and letters, the author comes to the conclusion that there is a complete lack of didacticism in Sokhanskaya, which realized the special role of monasteries that can help people in secular life and bring affirmation in faith. In the annex to the article for the first time valuable extracts of Sokhanskaya letters are published, conveying the writer's impressions of the beauty of Russian monasteries and glorifying them.
\end{abstract}

Keywords: N. S. Sokhanskaya, Kokhanovskaya, monasteries, monastic topos, Lavra, church subjects, Orthodoxy, Slavophilism

Information about the author: Olga L. Fetisenko, DSc in Philology, Leading Researcher, Institute of Russian Literature (Pushkin House) of the Russian Academy of Sciences, Makarova st. 4, 199034, St. Petersburg, Russia

E-mail: betsy98@mail.ru

Received: October 14, 2019

Published: December 10, 2019

For citation: Fetisenko O. L. Four Laurels: a monastic theme in the artistic, journalistic and epistolary heritage of Kokhanovskaya (N. S. Sokhanskaya). Two centuries of the Russian classics, 2019, vol. 1, № 2, pp. 94-109. (In Russ.) DOI 10.22455/2686-7494-2019-1-2-94-109 
Кохановская - литературный псевдоним русской писательницы украинско-польского происхождения, Надежды Степановны Соханской (1823-1884), которым она пользовалась с 1856 г. Родилась она на территории будущей Белгородской губернии, но вся ее жизнь прошла на Слободской Украине: на хуторе Макаровка в Изюмском уезде Харьковской губернии. В Харькове она с шифром кончила курс в Институте благородных девиц. В повестях Кохановской конца 1850-х гг. («После обеда в гостях», «Из провинциальной галереи портретов», «Гайка») славянофилы увидели живой ответ своим чаяньям от литературы: искомое «положительное отношение» к действительности. Кохановская стала сотрудницей «Русской беседы», а затем газеты «День» и последующих изданий И. С. Аксакова. В 1863 г. Аксаков выпустил два томика ее повестей. Незадолго до этого времени литературные критики других направлений, наперебой хвалившие Кохановскую, ославили ее проповедницей «отживших идеалов», а затем просто утратили к ней интерес.

В творчестве писательницы выделяются два основных направления: увековечение старины с ее преданиями, святынями, песенной традицией и речевой архаикой и, с другой стороны, отклик на текущие события в их «маленьких частностях» ${ }^{1}$ [Макаровская, 1854 (a): 448]. Сетуя на отсутствие в России подлинной «литературы фактов», Соханская ставила перед собой при собирании «живых заметок» ту же самую задачу, что и в художественной «археологии», - изучение «родного нашего осязательно-присущего духа» [Макаровская, 1854 (б): 617], и подходила к решению этой задачи как историк национального самосознания. Те же два направления проявились и в обращении к монастырской теме: закрепление в художественном слове старины, например, такого явления как странничество ${ }^{2}$, и публицистическое

1 Выражение из очерка Соханской «Письмо из Малороссии».

2 Странница из повести «После обеда в гостях» (1858) «всюду была: в Киеве, и в Почаеве, и у Соловецких угодников была» [Повести Коханов- 
освещение современности: возрождение Святогорской обители, непростое положение Почаевской лавры ${ }^{1}$.

В повестях Соханской «дославянофильского» периода монастырская и вообще церковная тематика не обнаруживается, хотя Надежда Степановна с детства была религиозна. Положение изменится, когда ее религиозность примет более церковное русло (чего нельзя было сказать об экзальтированном благочестии институтки) и станет теснее связана с монастырями. Посещениями обителей или заочными с ними контактами размечены вехи даже собственно писательской ее жизни: окончив работу над крупным произведением (повестью «Рой-Феодосий Саввич на спокое») Кохановская едет в ближайший к ее хутору ${ }^{2}$ монастырь (Святогорский, о нем мы скажем дальше), а на гонорар от публикации той же повести заказывает в иконописной мастерской Троице-Сергиевой лавры большой - в размер храмового - образ Неопалимой Купины.

В последующих литературных обращениях к топосу монастыря у Кохановской не было ничего нарочито дидактического. Писательница касается этих реалий ровно настолько, насколько монастырские впе-

ской: Т. 1. С. 46]. В семейной хронике «Старина» (1855-1860) рассказано о том, как принимал «богомольцев родной земли» дед писательницы: «Сложив котомки в его собственной большой горнице, приставив к стенам свои посошки, - кто из них, в ожидании ужина, располагался греться или сушиться у печи, - кто, прикурнув на руку к своему путевому бремени, сладко засыпал при нем; другие, попочетнее, люди бывалые, вступали в разговоры с дедушкой. И было что порассказать иным, которые лет десять и пятнадцать ходили по богомольям: один год в Киев и до Почаева, а другой - в Москву и к Троице-Сергиевой Лавре; были удостоившиеся побывать и у Соловецких угодников» [Старина: 264]. Странников принимала и мать Надежды Степановны. Удивительный рассказ одной из таких паломниц о медведе, чаевничавшем с тремя заночевавшими в архангельских лесах странницами, передан в письме к А. В. Плетневой от 13 марта 1868 г;; Кохановская намеревалась превратить бесхитростное повествование в рассказ для народного чтения. Неизвестно, исполнила ли она свое намерение.

1 «В местечке, которое облегает монастырь и находится у самых его св. врат, нет ни одной души христианской. <..> у этой лавры, стоящей светилом восстановленного православия лицом к лицу с униатско-латинским Западом, нет ни одного жителя-христианина...» [Кохановская, 1967 (a): 4]. Название статьи дано И. С. Аксаковым.

250 верст степной дороги. 
чатления были составной частью жизни мирянина: паломничество, желание принести к мощам угодников или чудотворной иконе свои скорби и радости; возможность видеть «чудный новый мир родной подвижнической святыни» ${ }^{1}$.

Раскаяние в своей гордыне и примирение с мужем героиня-рассказчица в повести «После обеда в гостях» знаменует их общим паломничеством к киевским угодникам. Туда же устремлен странник в повести «Кирила Петров и Настасья Дмитрова» (1861): «...я в Киев иду. Снесу я твой грех великий к великим заступникам и молителям Русской Земли. Мы не умолим с тобой, они умолят по нас» [Повести Кохановской, 2: 283]. В той же повести главные герои в трагический период своей жизни приезжают под праздник Покрова в Святогорский монастырь (гл. VI), но их паломничество оказывается неудачным, так как не умягчается окаменевшее сердце Кирилы, убитого известием о недевственности невесты-жены.

Четыре лавры было в Российской Империи - Киево-Печерская, Троице-Сергиева, Александро-Невская и (с 1833 г.) Почаевская. Земляки Кохановской посещали главным образом Киев и Почаев. Странники доходили и до обители св. Сергия, и до Соловков, заместивших в этой четверице новую и более «официозную» в глазах народа петербургскую святыню2 ${ }^{2}$ Кохановская бывала во всех четырех лаврах: в Киево-Печерской во время Русско-турецкой войны, в Троице-Сергиевой и Александро-Невской - несколько раз во время приездов в Москву и Петербург, в Почаеве - в 1866 г., а, возможно, и позднее, во время своей второй поездки на Волынь в 1877 г. В названии нашей статьи, однако, сознательно нарушена хронологическая привязка к той эпохе и под четвертой лаврой подразумевается не петербургский монастырь, но обитель, которая получила статус лавры уже в наше время - Святогорский монастырь на меловых горах на берегу Северского Донца

\footnotetext{
1 Цитата из незавершенного романа «Степная барышня 40-вых годов» [Степная барышня: 9]..

2 Кстати, Кохановская интересовалась и Соловками, поэтому придирчиво-внимательно она в 1874 г. отнеслась к очеркам Вас. И. Немировича-Данченко. [Семья Аксаковых: 307-308]

3 Время основания монастыря неизвестно; в начале XVII в. он был разорен, а позднее (в 1787 г.) и упразднен (сохранялся лишь как приходская церковь). Восстановлен в 1844 г. и возрождался при помощи Т. Б. Потемкиной, муж которой владел этими землями. После десятилетий нового
} 
Его, как ближайший к Макаровке, Кохановская посещала чаще других и, естественно, чаще упоминала его в своих текстах (указанная выше глава в повести «Кирила Петров...», «Письма с хутора» и др.).

Эпистолярий писательницы содержит несколько связанных со Святыми Горами эпизодов: о приездах туда Царской семьи и о встречах с имп. Марией Александровной, которой Кохановская была представлена еще в 1862 г. в Петербурге, и с Т. Б. Потемкиной, на чьи средства восстанавливался монастырь, пришедший в XVIII в. в полное запустение; об освящении храмов (в частности об освящении Преображенского храма в 1864 г.), о праздничных службах, о том, например, как Великим четвергом 1864 г. до пяти часов пополудни причащали из нескольких чаш 6500 причастников-паломников. Несомненно, все эти фрагменты заслуживают скорейшей публикации и могут быть полезны в первую очередь самому возрожденному монастырю.

Первое из развернутых художественных описаний Святогорского монастыря обнаружено нами в неопубликованном письме Соханской к ее литературному наставнику П. А. Плетневу от 26 августа 1849 г. ${ }^{1}$ В этом эссеистическом фрагменте, начатом по следам только что совершенной поездки, больше говорится о впечатлениях 1844 г., когда Соханская сопровождала помещицу-вдову П. В. Грекову, к сыну которой поступила в гувернантки. К сожалению, фрагмент прерван на подробном описании пейзажа и монастырских руин (Соханская хотела передать, каким был монастырь перед началом его восстановления). В сентябре 1863 г. Соханская напишет Плетневу в Париж о своих новых святогорских впечатлениях. Она хочет всех своих друзей приобщить к дорогой южнорусской святыне, чтобы они тоже хотя бы по изобра-

разорения обитель была открыта в 1992 г., а в 2004 г. получила статус лавры (Святогорская Успенская лавра).

1 ИРЛИ. Ф. 234. Оп. 3. Ед. хр. 621. Л. 42-43 об. Есть, правда, и более раннее упоминание: в письме к тому же лицу от 10 мая 1848 г. Соханская сообщала о том, что ее семья собирается в паломничество и восклицала: «...уже более года, как я не была в Святых Горах - чудесное место! Как хороша эта церковка, как бы приклеенная к горам! Беленькая; вверху сосновый лес; весь скат горы покрыт черным лесом, кустарники нависли; внизу Донец; луговая сторона как бархат стелется и по нем, точно рассаженные, страшные дубищи; на каждом - думается - сидит Соловей-разбойник: право, моих охватов пять будет и такие живописные эти дубы - широкие, раскидистые. 
жениям знали «Святогорскую скалу и эту меловую церковь на скале в красоте и зелени соснового леса» ${ }^{1}$.

Киево-Печерская лавра воспета в первой главе романа «Степная барышня сороковых годов» ${ }^{2}$ и в очерках «Поездка на Волынь» (1867):

«...на верхах гор, другими золотыми верхами, вознесся и соорудился Киев, в своем Днепровском Иордане окрестил славянские племена в православную Русь, и с летописных времен стал он и до днесь устоял почти тысячелетним памятником давней нашей великокняжеской славы, монгольских и польских бедствий и просиял святынею на весь Русский мир. Киев на своей Печерской горе, онебесившийся, как поет церковная песнь, идеже светозарные звезды, преподобные отиьь, молитвенные лучи к Богу Свету о отечестве своем простираюшие по ту сторону Днепра, - Киев оттуда всем своим лицом, всем сиянием Киево-Печерской лавры и судьбами своей истории обращен сюда, на эту сторону. Он достойно народному величию запечатывает грань отдела южно-русской земли и приурочивает Малороссии святой крещальный Днепр» [Кохановская, 1867 (в): 2].

Почаевская лавра (с ней Кохановская познакомилась, когда стала «сестрой»-вкладчицей одного из беднейших православных братств на Волыни - Георгиевского Яполотского), «наша последняя православная святыня на рубеже австрийской и униатской Галиции» [Кохановская, 1867 (a): 4], стала предметом ее внимания как публицистки во второй

${ }^{1}$ Цитата из письма к А. В. Плетневой от 11 мая 1864 г. ИРЛИ. Оп. 4. Ед. хр. 163. Л. 14 об. Речь идет о приобретенном для А. Ф. Тютчевой образе св. Николая Чудотворца на финифти, на обратной стороне которого было изображение монастыря (один из его храмов был посвящен Мирликийскому чудотворцу). Гравюру со святогорским видом Соханская послала В. С. Аксаковой, но подарок не застал ту в живых. [Семья Аксаковых: 226].

2 «Эти пещеры, эта нить таинственных ходов внутри земли с затворами и самовольными заклепами; эти показывающиеся воображению неисчислимые мощи Святых, благоухающие целостью нетления! - богослужение, в котором земное величие святыни преобразилось небесною славою в хорале торжественного, неисповедимого напева голосов, то гремящих какими-то перекатными громами звука архангельского, то смиряющихся до нежности святого сладостного пения, заливающего душу умилением!..» [Макаровская, 1885: 9].

3 Цитируется молитва преп. Антонию и Феодосию и прочим Печерским чудотворцам (из службы им в неделю 2-ю Великого поста). 
половине 1860-х гг., причем главным образом в связи с этноконфессиональными вопросами. Надежда Степановна оказалась вовлеченной в почти детективную историю некоей Кейлагильды Мельцер: священник отказывал той в крещении, опасаясь мщения иудейской общины; девушка и ее жених (поляк-католик) обратились за помощью к приезжей, приняв ее за знатную госпожу. Через год на страницах аксаковской газеты Кохановская будет выступать против такого положения дел в государстве, когда «еврею, магометанину (не говоря уже о христианских исповеданиях) - всем дозволяется быть ревнителями по вере своих отцов, и только в отношении нас самих, православных, это называется поповским фанатизмом и узким квасным патриотизмом» [Кохановская, 1867 (б): 4].

В личной же судьбе писательницы всё большую роль начинала играть Троице-Сергиева лавра. Здесь в 1862 г. она нашла духовного отца («отца Николая из сельских священников» ${ }^{1}$ ) и еще одного дивного старца, имя которого она не называет в письмах, ласково встречавшего ее словами: «сладкое чадо»²; сюда она приезжала говеть и позднее. Попрощалась с Лаврой Надежда Степановна в свой последний приезд в Москву в 1883 г., когда она уже знала о своей неизлечимой онкологической болезни. На основную болезнь наслоился еще и «подхваченный» в Москве тиф. Едва оправившись от него, к удивлению друзей, она поехала в монастырь и вернулась из Сергиева Посада укрепленная на дорогу домой, на Украину, куда приехала к Рождеству.

У себя на хуторе Надежда Степановна хранила многие памятки «от св. Сергия», последней из них стала подаренная А. Ф. Аксаковой на прощанье в декабре 1883 г. икона Преподобного. Дочь Ф. И. Тютчева еще до замужества, в бытность фрейлиной и воспитательницей младших царских детей, получила эту икону от императрицы Марии Александровны после лаврского говения великого князя Сергия Александровича, будущего генерал-губернатора Москвы.

${ }^{1}$ Письмо к А. В. Плетневой от 29 августа 1862 г. (ИРЛИ. Ф. 234. Оп. 4. Ед. хр. 162. Л. 75 об.).

2 Слова этого старца, сказанные ей и сопровождавшей ее крестьянке Лукии, она помнила и через 21 год: «Чада мои милые! чада мои сладкие! вот и хорошо вам, госпоже и служанке! И держитесь так-то дружка за дружку...» (приводятся в письме к А. В. Плетневой от 15-24 сентября 1883 г. перед последней поездкой в Москву. (ИРЛИ. Ф. 234. Оп. 4. Ед. хр. 164. Л. 102). 


\section{Приложение}

\section{I. О Святогорском монастыре}

\section{Письмо Н. С. Соханской к П. А. Плетневу}

26 августа 1849 г. ${ }^{1}$

$<\ldots>$

Я буду говорить о Святых Горах. -

Вот что сказал о них сладкоглаголивый Иннокентий ${ }^{2}$ именно на обеде у Марьи Ивановны ${ }^{3}$, возвращаясь с обновления Святогорского монастыря. «Я изъездил Европейскую Россию, могу сказать, вдоль и впоперег <так>, но живописнее места Святых Гор не встречал». Правый берег нашего Донца чрезвычайно горист, очень живописен видами и самым цветом своих подгорных холмов и утесов. Снежный мел и глина всевозможных красок почти в радужных переливах одевают взгорьи. Не говоря уже о серой и обыкновенной желтой, есть глина совершенно палевая - зеленоватая, синяя с светлыми отливами; я видела огромную покатость холма чисто красную, просто пурпуровую и по ней купами разбросаны кустарники: дуб вместе и дикая груша, яблонка и дикая роза в цветах. Не говорите, что у нас нет своей Италии; она есть, да только «несть пророк без чести, токмо во отечествии своем» ${ }^{4}$. Святые Горы над самым Донцом, через который идет плавучий мост. Собственно, это не горы, а букет меловых утесов, чудной рукою Создателя приколонный к груди всегда зеленых, крутых гор. Эту всегдашнюю зелень составляет неизмеримое протяженье бора, сливающееся по покатостям в чащу орешника, боярышника - всего царства хвойных лесков и перекинувшееся по ту сторону реки, на заливные луга, огромным, вековечным лесом таких дубов, что в одном из

1 Автограф: ИРЛИ. Ф. 234. Оп. 3. Ед. хр. 621. Л. 42-43 об.

2 Иннокентий (в миру Иван Алексеевич Борисов; 1800-1857) - епископ Харьковский и Ахтырский (с 1841), архиепископ Херсонский и Таврический (с 1848), богослов, духовный писатель, проповедник; канонизирован в 1997 г.

3 Мария Ивановна Шидловская (урожд. Капустянская; 1767-1855) богатая помещица, вдова изюмского уездного предводителя дворянства (1783-1786, 1801-1804) Николая Романовича Шидловского (кон. 1750-х - нач. 1760-х - 1820). О роли М. И. Шидловской в жизни Соханской, о «гощениях» в ее имении Кунье подробно рассказано в автобиографии писательницы.

${ }^{4}$ Мф. 13: 48. 
них несколько выгнило дупло и наш рослый мужичек во всей одежде своих шуб и полушубков прячется в нем, как в театральном шкафе. Горы эти и их леса полны преданий о харцызах (это туземные разбойники), о закопанных ими кладах, о пещерах, где были притоны их; где находят старое железо и серебряные кованные околыши их высоких запорожских шапок. По протяженью этих лесов и теперь водятся куницы и дикие козы; в заливах Донца есть выдры и еще так недавно как трудно этому поверить! - что еще не поумерли те люди, которые травили здесь медведей.

Но, чтобы подробно говорить о Святых Горах, дайте я вам расскажу, как я их увидела в первый раз, когда ехала с Грековой ${ }^{1}$. Вы тем более должны мне это позволить, что мой рассказ уже одно предание. Как я видела тогда Святые Горы, так их уже никто более не увидит; никому они не вспомнятся в таких глубоких картинах мира и уединенной святыни, обвеваемые грустной поэзией чувства, как колыханьем своих навершинных сосен.

Откуда бы ни ехать в Святые Горы, но миновать дороги семи, восьми и до пятнадцати верст бором нельзя. Мы ехали 9 августа. Пошел проливной дождь, совсем смерклось, когда мы почти ощупью добрались до Татьяновки², небольшого селения в одну линию, лицом прямо к Святым Горам, которое находится на луговой стороне у подлесья, оставляя между собою и монастырем то пространство, которое захватывается Донцом во время весеннего разлива. Это селеньеце есть преддверие Святых Гор. Прежде далее его и не ездили; все останавливались здесь и отправлялись к монастырю пешком или в экипаже у Донца; но в самый монастырь въехать было нельзя: прямо против моста на крутом берегу, как на обрыве, стояла святая брама, обходили ветхие, каменные стены монастыря и между ими и рекой было так мало пространства, что могла проехать одна телега, а поворотиться с экипажем было невозможно. Хотя Святые Горы были простым приходским местом; но усердие к ним богомольцев сделало то, что в упраздненном монастыре каждый день совершалось служение. Удар колокола к заутрени разбудил меня. Мы поехали

\footnotetext{
1 Пелагея Васильевна Грекова - помещица Бахмутского уезда, вдова хорунжего А. С. Грекова.

2 Татьяновка - имение Александра Михайловича Потемкина (17871872), названное в честь его жены, статс-дамы Татьяны Борисовны Потемкиной (урожд. кнж. Голицыной; 1797, по др. свед. 1801-1869).
} 
при фонарях; как вчера, так и теперь от туч было чрезвычайно темно, и я напрасно силилась рассмотреть хотя что-нибудь: кроме какого-то беловатого пятна на ужасной громаде темноты и леса, я ничего не видела. Блестели свечки кое-где в церкви (день был простой, не праздничный); от сырости, что ли? воздуха уныло звучал колокол; мы взошли под арку святой брамы, вступили в самый монастырь, за его ограду, не встречая никаких ворот и никакого затвора; только моему воображению мечталось, что как бы заснувшим сторожем, между церковью и брамою, стоял огромный, дебелый дуб; у него были густые ветви и он, как клобук, угрюмо надвинул их. Тогда только еще прорывался слух, что монастырь возобновится; живым представленьем этого слуха был кто-то такой в монашеской ряске, с длинными волосами - задумчивый, подпоясан узеньким ремнем; он стоял среди церкви и, по-монашески, протяжно и с возгласами читал псалмы. Церковь эта была соборною во времена древнего монастыря; она во имя Успения Божией Матери; очень не велика, каменная; построение ее относят к 1698 г. - простая церковь с иконостасом к самому верху и с вызолоченными серебряными венцами на наместных иконах. Явленная икона чудотворца Николая лежит здесь на налое; отсюда, при акафистном пении, ее носят в верхнюю церковь; нечего и говорить, что эта икона в дорогой серебряной, жарко позолоченной ризе. Любопытно, каким образом, наши поселенцы, волохи ${ }^{1}$ и сербы приносят свои посильные вклады: они прикладываются к иконе и прилепливают вощечком к ее киоту и стеклу киота, что дает их усердная щедродательность - и икона является усеянною звездочками разнокалиберной серебряной монеты.

Но я с нетерпением ожидала, когда начнется молебен, чтобы идти вверх, к церкви Святителя Николая из мела, выделанной в скале. Я боялась, что пойдут пещерами и я утеряю прекрасные виды с горы; но пещеры в некоторых местах обвалились; священник отказался после утрени служить молебен: что в гору идти скользко; мы приглашены были к нему в дом до обедни. Мне не сиделось; я кое-как укралась от заботливого внимания Грековой, избавилась от последования лакеев и вот что я увидела - я не сумею пересказать вам хорошо.

Сияло раннее утро; несмотря на весь его блеск и еще усиленный биллионами капель перешедшего дождя, в нем уже чувствовалось что-то

${ }^{1}$ Волохи (влахи) - одно из восточно-романских племен; в России так чаще всего называли молдаван. 
тихое и задумчивое - приближенье осени. Беззвучными струями текла река; высокие горы, все в лесу, в соснах как в стоячей щетине, уступом отдались от берега и в этом уступе, завернувшись в мантию зелени, приютился монастырь и когда подумаешь, что он уже был здесь, когда еще у нас были Князья и они воевали с половцами! Поэт-живописец не расстался бы с этим местом самого восхитительного запустения. Каменные стены монастыря, вероятно от лет и непогод сделавшиеся такими низенькими, что корова протянула через них голову и обгладывает молодые ветки, эти стены в свое время составляли правильный четвероугольник; сколько можно судить, по углам их стояли круглые башенки: двух башенок с задней стороны уже почти нет, только виднеются груды щебня; но одна напереди еще стоит бодро, как пирамидальным купольцом; из-под странного колпака выдирается на свет сосёнка и как она молода и зелена на развалине! ее обогнал хмель, обвертелся в тысячи изгибах, зацепился за ржавый гвоздь, повис и падает кистями. Растительность ринулась в забытый монастырь; кусты бузины, калины; стоит кудрявая яблонка; задняя стена вросла в гору; орешник с плодами...

\section{Письмо к А. В. Плетневой 11-12 мая 1864 г. ${ }^{1}$}

$<\ldots>$

Из Старобельска я с своими кумами роехала в Святые Горы. Именно там, в обители Божией Матери, мне хотелось поблагодарить Ее и через Нее Господа, у Которого вся наша мудрость человеческая и красота и сила и истина наших художественных дел - поблагодарить за дело моего «Роя» ${ }^{3}$ И я поблагодарила по завету псаломскому. «Что

${ }^{1}$ Автограф: ИРЛИ. Ф. 234. Оп. 4. Ед. хр. 163. Л. 13-14 об.

2 Речь идет о подруге Соханской, Надежде Дмитриевне Шамониной (урожд. Башкирцевой; 1830-1908), тетке художницы М. Башкирцевой. Муж Шамониной Николай Иванович (1824-1887) служил по ведомоству Министерства внутренних дел. Их сын Владимир (1860-1909) был крестником Соханской, а старшая дочь Надежда (1861-1928, впоследствии - жена историка акад. С. Ф. Платонова), возможно, и названная в знак дружбы ее родителей с писательницей, стала ее биографом [Платонова].

${ }^{3}$ Повод к благодарению - завершение работы над повестью «Рой-Феодосий Саввич на спокое», задуманной еще в 1861 г. 
воздам Господеви о всех яже воздаде ми? Чашу спасения приму и имя Господне призову. Молитвы моя воздам пред боящимся Его - посреди церкви велицей...»ํ. И именно, Сашенька, какая великая церковь братий наших, поклоняющихся Господу на святом месте Земного храма Его, была и поклонялась со мною! Ты писала, что у отца Агапита на второй недели поста было 700 причастников. Это очень много и слава Богу! Но представь же, что в Святых Горах на Страстной Неделе было столько поклонников, что ни церкви, ни собственно монастырь не вмещали их, а народ стеною стоял на берегу Донца и в Чистый Четверг приобщающихся было 6500 чел<овек>! Так называемое «Правило», т. е. молитвы ко Св. Причащению, читали в нескольких местах на дворе монастырском, потому что чтение собственно в церквах не могло быть слышимо бо̀льшей части народа. Сколько нашлось сосудов в монастыpe, изо всех приобщали народ и могли приобщить его только к 5-ти часам пополудни! В простоте своего слова прекрасно мне сказал монах, говоря об этом. «Это уже дело Божие. Вера их, людей-то, матушка; а человечески - что тут поделаешь?» Именно, что поделаешь - как человечески удовлетворишь по всем определенным правилам и уложениям духовную жажду сонма верующих, приступивших к Богу такою тысячною, народную, всерусскою толпою! Один Богочеловек, напитавший некогда пять тысяч пятью хлебами, - и эти 6 тысяч напитал, как Сам знал своим Пречистым Телом и в жажде их напоил Своей Кровию.

$<\ldots>$ Анна Федоровна молчит <...> она мне прислала «Последние дни И<исуса $>$ Христа» ${ }^{2}$, и я, бывши в Св. Горах так желала в свою очередь что-нибудь послать ей и нашла прекрасный на финифьте образ Св. Николая явленного там, а на оборотной стороне Святогорскую скалу и эту меловую церковь на скале в красоте и зелени соснового

1 Соединение точной и свободно контаминируемых цитат: Пс. 115: 3-5, 10; 21: 26; 39: 10.

2 Ср. в письме к А. В. Плетневой от 16 апреля 1864 г. (Великий четверг): «К Тютчевой я не писала 4 месяца, а она мне на днях прислала давно желанную книгу Пр<еосвященного> Иннокентия «Последние дни жизни И<исуса > Христа”» (ИРЛИ. Ф. 234. Оп. 4. Ед. хр. 163. Л. 12). Подарок А. Ф. Тютчевой (в замуж. Аксаковой; 1829-1889) - книга архиеп. Иннокентия Херсонского «Последние дни земной жизни Господа нашего Иисуса Христа, изображенные по сказанию всех четырех Евангелистов», впервые изданная в Одессе в 1857 г. в 5 частях) - был приурочен к Пасхе. По-видимому, было послано 2-е издание, вышедшее в Одессе в 1860 г. 
леса. И моя дорогая Сашенька! Как мне хотелось и тебе дать какой-нибудь вещественных знак того, что я радовалась в Св. Горах, благодаря Бога и Матерь Божию за своего Роя, и поминала в молитве и всех вас, и тебя мою несравненную, далекую милую и милую.

\section{II. Говения в Троице-Сергиевой лавре}

Из писем к А. В. Плетневой

29 августа 1862 г. ${ }^{1}$

Вот, моя Сашенька дорогая! ваша Ната ${ }^{2}$ не только в Москве, а уже третий день в Троицко-Сергиевой Лавре и вот уже поговела, и вот уже приобщилась - и как всё мне хорошо само собою слагается - осмелюсь сказать: милостию Божией дается. Думая о духовнике и не зная к кому обратиться за советом, я вижу бредущего именно старца с чуть передвигаемыми отекшими от стояния ногами, но с славной атлетической головою, густо покрытой мало того совершенно белыми, а даже позеленелыми волосами. Я подхожу к нему прямо и говорю: вот так и так, батюшка, кого вы мне можете указать в духовники? Я прошу Вашего совета... И, Сашенька моя милая, представьте себе раннее утро, широкие ступени древнего, еще отворенного храма, какие-то удивительно странные выпуклые и с перехватами колонны в скульптурных цветах, Ангелов в простенках, свежую зелень наклонившихся ветвей и услышьте эти слова простоты и святой сердечности патриархальной: «Чадо мое сладкое! духовника тебе? Ну, слышу, слышу...» И я другой день, как музыку, слышу это наименование сладкого чада, которое заставляет меня и улыбаться, и умиляться. И вот он привел мне духовника отца Николая из сельских священников, и вот я сегодня, не зная о всей святости великого места, сообщилась св. Таин в небольшой церкви Сошествия св. Духа, самой древней и той самой, в которой сходил видимо св. Дух, когда священнодействовал преподобный Сергий и здесь же в глухом приделе почивают мощи великого знаменитого ис-

${ }^{1}$ ИРЛИ. Ф. 234. Оп. 4. Ед. хр. 162. Л. 75-75 об.

${ }^{2}$ Ната - уменьшительное не от «Надежды», но от «Наталии» (так зовут нескольких героинь Кохановской) - домашнее имя Н. С. Соханской. Различение «Нади» и «Наты» было необходимо, потому что в семье была еще одна Надя, любимая двоюродная сестра писательницы. 
правителя книг Максима Грека ${ }^{1}$. Он прекрасно живописан на доске его серебряной раки - с пером в руке и с глядящими острыми глубокими глазами.

\section{0 сентября 1862 г. ${ }^{2}$}

А как я прекрасно отпраздновала свой день Ангела! В воскресенье 16 уехала в Троицу и пробыла там светло и радостно в доме Отца Небесного - приобщилась, Сашенька! Столько благодати! И так всё неожиданно. Я думала о том и раздумывала: без говенья и когда я, приехавши на вечерни, отыщу еще своего духовника: что он скажет на это и позволит ли. Вхожу в Успенский храм, тот мой чудный старик изумленными глазами увидел меня. «Ты ли это, мое чадо сладкое! еще приехала к нам... Умеешь держать свое слово, умеешь, сладкое чадо!..» Я еще смотрю на него, желая насмотреться и нарадоваться духом на старческую красоту его. Не знаю, успела ли я еще ответить ему, как сзади меня называют по имени, я оборачиваюсь и это мой духовник, отец Николай. Я отвожу его в сторону и говорю, что вот я завтра имянинница и что мне хотелось бы приобщиться св. Таин, если можно.

- А отчего же нельзя? В день вашего Ангела и прекрасно - можно. Вот вам книжечка, прочитайте правило. Можно, очень можно.

Ax, моя Сашенька! какое богатство святейшей любви сокрыл Господь в своих Таинствах! И я приобщилась в прекраснейшей церкви Пр<еподобного> Сергия и день был прекраснейший. Пешком с Лукиею я ушла в Вифанию ${ }^{3}$ и шла полем, шла лесом, белые березы серели стволами во мхе, яснело голубое небо, вода, тоже голубея, мелькала в глазах и в понависших кустах... Велик Господь в Его земном твореньи!

\footnotetext{
1 В настоящее время мощи св. Максима Грека перенесены в Трапезный храм Лавры.

2 Автограф: ИРЛИ. Ф. 234. Оп. 4. Ед. хр. 162. Л. 78 об.-79.

3 Имеется в виду Вифанский Спасов монастырь (в настоящее время один из скитов Троице-Сергиевой лавры), основанный в 1783 г. архиепископом (впоследствии митрополитом) Платоном (Лёвшиным).
} 


\section{Список литературы}

Кохановская <Соханская Н. С.> Еврейская привилегия // Москва. 1867а. 15 июля. № 84. С. 4.

Кохановская <Соханская Н. С.> К делу об еврейских привилегиях // Москвич. 18676. 31 дек. № 5. С. 4.

Кохановская Поездка на Волынь. III // Москва. 1867в. 29 марта. № 70. С. 2. 9.

Макаровская <Соханская Н. С.> Письмо из Малороссии // Санкт-Петербургские ведомости. 1854a. 27 апр. № 91. С. 448.

Макаровская <Соханская Н. С.> Степная барышня 40-вых годов // Русь. 1885. 2 февр. № 5. С. 9

Макаровская <Соханская Н. С.> Еще письмо из Малороссии // Санкт-Петербургские ведомости. 18546. 8 июня. № 125. С. 617.

Платонова Н.Н. Кохановская (Н. С. Соханская). 1823-1884. Санкт-Петербург: Сенатская тип., 1909. 234 с.

Повести Кохановской: в 2 т. М.: тип Бахметева, 1863.

Семья Аксаковых и Н. С. Соханская (Кохановская): Переписка (1858-1884) / сост., вступ. ст., подгот. текста и коммент. О. Л. Фетисенко. СПб., 2018. С. 307-308.

Старина // Русское обозрение. 1898. Январь С. 264.

\section{References}

Kokhanovskaia $<$ Sokhanskaia N. S. $>$ Evreiskaia privilegiia [Jewish privilege]. Moscow. 1867. July 15. № 84. P. 4. (In Russ.)

Kokhanovskaia <Sokhanskaia N. S.> $K$ delu ob evreiskikh privilegiiakh [Jewish privilege case]. Moskvich. 1867. December 31. № 5. P. 4. (In Russ.)

Kokhanovskaia Poezdka na Volyn'. III [A trip to Volyn. III]. Moscow. 1867. March 29. № 70. P. 2, 9 (In Russ.)

Makarovskaia <Sokhanskaia N. S.> Pis'mo iz Malorossii [Letter from Little Russia]. Sankt-Peterburgskie vedomosti [Saint Petersburg Vedomosti]. 1854. April 27. № 91. P. 448. (In Russ.)

Makarovskaia <Sokhanskaia N. S.> Stepnaia baryshnia 40-vykh godov [Young lady of the 40s]. Rus'. 1885. 2 fevr. № 5. P. 9 (In Russ.)

Makarovskaia $<$ Sokhanskaia N. S. $>$ Eshche pis'mo iz Malorossii [Another letter from Little Russia]. Sankt-Peterburgskie vedomosti [Saint Petersburg Vedomosti]. 1854. Jule 8. № 125. P. 617. (In Russ.)

Platonova N. N. Kokhanovskaia (N. S. Sokhanskaia). 1823-1884. St. Petersburg, Senatskaia tip. Publ, 1909. 234 p. (In Russ.)

Povesti Kokhanovskoi: v 2 t. [The Story of Kokhanovskaya: in 2 vols]. Moscow, tip Bakhmeteva Publ, 1863. (In Russ.)

Sem'ia Aksakovykh i N. S. Sokhanskaia (Kokhanovskaia): Perepiska (1858-1884) [The Aksakov family and N. S. Sokhanskaya (Kokhanovskaya): Correspondence (1858-1884)], sost., vstup. st., podgot. teksta i komment. O. L. Fetisenko [compiled, introductory article, text preparation and commentary. O. L. Fetisenko]. St. Petersburg, 2018. pp. 307-308. (In Russ.)

Starina. Russkoe obozrenie [Russian review]. 1898. January. P. 264. (In Russ.) 


\title{
Логика творчества И. А. Гончарова: к постановке проблемы
}

\begin{abstract}
Аннотация: В статье ставится вопрос о логике развития творчества Гончарова, о главной идее, которую он выработал уже к концу 1830-х - началу 1840-х гг. и последовательно развивал в своей романной трилогии. Она связана с проблемой сохранения религиозного сознания современного человека в условиях резкого перелома истории и выхода человечества из «младенческой веры» и мифопоэтического сознания на фоне бурного прогресса науки. Рассматриваются истоки и причины глубокого интереса Гончарова к развитию науки и техники, в особенности, к открытиям астрономии. Предмет художественного исследования Гончарова сформировался в студенчестве - при изучении «Божественной комедии» Данте. Наиболее зримыми признаками творческой ориентации Гончарова на «Божественную комедию» являются фамилии главных героев, восходящих от «Ада» (Адуев) к «Раю» (Райский). Логика развития романной трилогии показывает, что все три романа были задуманы как части одного целого в одно время. Исторический оптимизм романиста зиждется на представлении о том, что научный и технический прогресс не входит в противоречие с Божьим Промыслом о человечестве, но способствует его реализации. Главенствующей здесь является мысль о «красоте» как самодостаточной силе, заложенной Богом в человеческую природу.
\end{abstract}

Ключевые слова: Гончаров, наука, религия, кризис, трилогия, Данте, логика творчества

Информация об авторе: Мельник Владимир Иванович, ORCID ID: 0000-00019684-8943, доктор филологических наук, член-корреспондент АН Республики Татарстан, Москва

E-mail: melnikvi1985@mail.ru

Дата поступления статьи в редакиию: 05.08.2019

Дата публикации статьи: 10.12.2019

Для цитирования: Мельник В. И. Логика творчества И. А. Гончарова: к постановке проблемы // Два века русской классики. 2019. Т. 1. № 2. С. 110-143. DOI 10.22455/2686-7494-2019-1-2-110-143 


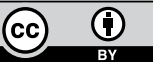

This is an open access article distributed under the Creative

Commons Attribution 4.0

International (CC BY 4.0)

\section{(C) 2019. Vladimir I. Melnik}

Moscow, Russia

\section{Logician of creativity I. A. Goncharov: to statement of a problem}

Annotation: The article raises the question of the logic of Goncharov's creativity development, about the main idea that he developed by the end of 1830 s - early 1840 s and subsequently developed in his novel of his trilogy. It is connected with the problem of preserving the religious consciousness of modern man in the conditions of a sharp change in history and the exit of mankind from the "infant faith" and mythopoetic consciousness against the background of the rapid progress of science. The origins and causes of Goncharov's deep interest in the development of science and technology, especially in the discoveries of astronomy, are considered. The subject of Goncharov's artistic research was formed as a student - in the study of Dante's "divine Comedy". The most visible signs of Goncharov's creative orientation to the "Divine Comedy" are the names of the main characters, ascending from "Hell" (Aduev) to Paradise (Raiskiy). The logic of the development of the novel`s trilogy shows that all three novels were considered as three parts of one whole at one time. The historical optimism of the novelist is based on the idea that scientific and technological progress are not in conflict with God's Providence for humanity, but contribute to its realization. The idea of a "beauty" as a self-sufficient and inherent in the human nature by God's power is dominant here.

Keywords: Goncharov, science, religion, crisis, trilogy, Dante, the logic of creativity

Information about the author: Vladimir I. Melnik, ORCID ID: 0000-0001-9684-8943, DSc in Philology, corresponding member Academy of Sciences of the Republic of Tatarstan, Moscow, Russian Federation

E-mail: melnikvi1985@mail.ru

Received: August 05, 2019

Published: December 10, 2019

For citation: Melnik V. I. Logician of creativity I. A. Goncharov: to statement of a problem. Two centuries of the Russian classics, 2019, vol. 1, № 2, pp. 110-143. (In Russ.) DOI 10.22455/2686-7494-2019-1-2-110-143 
Выявление логики творчества писателя, на наш взгляд, предполагает определение и анализ развития той главной идеи, которой он руководствовался на протяжении всей жизни, ибо при всем разнообразии тем, мотивов, образов, поэтических приемов в различных произведениях одного и того же автора, при всем множестве частных задач (например, Л. Н. Толстой сказал: «... в “Анне Карениной” я люблю мысль семейную, в “Войне и мире” любил мысль народную» [Толстая: 502]), в творчестве большого писателя всегда есть та «стволовая» идея, которую он многообразно развивает от произведения к произведению и которая составляет оригинальное содержание его мира. В выборе и характере разработки этой идеи, собственно, и проявляется его неповторимое понимание жизни и человека. Исследование частных вопросов художественного творчества так или иначе ведет к уточнению наших представлений о главном предмете внимания писателя, однако рано или поздно появляется необходимость обобщения, позволяющего увидеть творчество автора в целом, выявить логику его развития. Подобное обобщение никогда не является окончательным, но всего лишь отражает степень и характер развития современной науки о писателе.

Вопрос о логике творческого развития для разных авторов имеет различную степень актуальности. Что касается И. А. Гончарова, то этот вопрос давно назрел, поскольку - при всем бурном развитии гончарововедения в последние три десятилетия и тщательной проработке массы частных проблем, в частности, с уклоном в культурологию, - нерешенными остаются как раз наиболее существенные филологические проблемы его наследия, относящиеся, прежде всего, к периодизации его творчества, пониманию феномена практически одновременного задумывания в 1840-е гг. тридцатилетним автором сразу трех романов («Обыкновенная история», «Обломов», «Обрыв»), а также к уяснению самой художественной природы его «трилогии» как целого, к философским и иным истокам его творчества и т. п. Об отдельных произведениях 
Гончарова существует целая литература, однако вопрос о логике творческого развития романиста до сих пор не ставился в гончарововедении, а между тем автор «Обломова» лишь на первый взгляд прошел типичный для русского реалиста XIX в. ясный и понятный путь от переводов и ранних стихов до нескольких «старческих» очерков в конце жизни, которые признаны слабыми произведениями [Цейтлин, 1950: 299-300] и которые предлагается отнести к разряду «творческих неудач» [Кубасов: 253].

Справедливости ради надо сказать, что любое серьезное исследование творчества Гончарова так или иначе затрагивает широкую проблематику, анализирует закономерности, наблюдаемые в мире идей и эстетики художника. В последнее время появились попытки уловить глубокие связи между романами писателя и разгадать феномен не совсем обычной романной «трилогии» [См., например: Шевырев: 118-180; Мельник, 2000: 31-34; Мельник, 2008: 280-284; Богомолова, 2009; Беляева, 2007; «Странные сближения»: 23-28; Беляева, 2007; «Тройственная nоэма»: 37-40]1․ Кроме того, немало работ посвящено поиску устойчивых мотивов, характерологии героев в трилогии Гончарова [Воробъева: 28-32; Кочетова: 281-288; Богомолова, 2009: 90-94; Доманский: 187-223]. Однако указанные попытки все-таки не позволяют понять, какова же та идея, которой руководствовался молодой еще Гончаров, сразу определивший главный вектор своего художественного развития на многие годы вперед и задумавший одновременно не один, а три романа, последний из которых будет опубликован лишь в 1869 г., когда сам писатель приблизится к шестидесятилетнему рубежу.

Сразу оговоримся, что в настоящей работе речь пойдет не столько о попытках изображения авторского идеала [см.: Мельник, 1985: 45-108; Мельник, 1991], сколько о том, что стоит, как правило, за изображаемым идеалом, - об авторской идее (хотя оба понятия можно разделить лишь условно).

В русской литературе Гончаров был одним из немногих художников, тяготевших к концептуальному мышлению и к завершенности художественной картины мира. Эпичность художественного мышления писателя, его тяготение к жанру большого романа - все это вырастало из потребности выражения идеи, адекватно отражающей духовно-нрав-

\footnotetext{
1 Термин «трилогия» встречается в библиографии Гончарова, начиная с 1927 г. [Цейтлин, 1927: 95-108], но в основном лишь в общем значении суммарного обозначения романного творчества писателя.
} 
ственную доминанту эпохи. Известно, что автора «Обломова» отличают необычайно масштабные обобщения. Так, В. А. Недзвецкий справедливо отмечал, что «принципиальной особенностью реалистической типизации Гончарова является все более возрастающее стремление брать разнородные преходящие общественные приметы своего времени не просто широко, суммарно, но возводить их к неким “главным”, или “коренным”, “племенным”, “основам” жизни в целом - русской и мировой» [Недзвеикий: 66]. Однако дело не только в том, что романист возводит «приметы времени» к коренным основам мировой жизни, ибо это обозначает лишь своеобразие эстетики и масштаб художественного мышления писателя, но ничего не говорит об идее, которую проводит Гончаров в своем творчестве. Между тем, отмеченная широта художественной типизации вырастала из масштаба философской мысли писателя, который пытался дать системный ответ на коренной, по Гончарову, вопрос современности: вопрос о сохранении религиозной основы жизни в условиях резкого перелома истории и «выхода из детства» человечества.

Что касается проблемы религии, то исследователи привыкли связывать ее исключительно с романом «Обрыв» (1869), который зачислен, как известно, в разряд «антинигилистических романов». Тем самым смысл романа сильно обеднен. Религиозная идея проявляется в творчестве Гончарова не в противопоставлении нигилизму (это лишь частный момент, актуализированный в «Обрыве»), а в противопоставлении нарастающему охлаждению и равнодушию к религии, в новых исторических условиях глубокого и всеохватного изменения сознания человека XIX в., не опровергающего религию, а утратившего серьезность, глубину и непосредственность религиозного переживания. О религиозном охлаждении общества Гончаров писал в «Необыкновенной истории»: «Человек, жизнь и наука - стали в положение разлада, борьбы друг с другом: работа, т. е. борьба кипит - и что выйдет из этой борьбы - никто не знает! Явление совершается, мы живем в центре этого вихря, в момент жаркой схватки - и конца ни видеть, ни предвидеть не можем!

Но продолжительное ожидание переходит в утомление, в равнодушие. Вот враг, с которым приходится бороться: равнодушие! А бороться нельзя и нечем! Против него нет ни морального, ни материального оружия! Он не спорит, не противится, не возражает, молчит и только спускается все ниже и ниже нуля, как ртуть в термометре. От этого равнодушия, на наших глазах, пало тысячелетнее папство!» [Гончаров, 2000: 272]. 
Принято считать, что столкновение традиционного религиозного мировоззрения с позитивной философией Гончаров показал в конце 1860-х гг. в романе «Обрыв» [Мельник, 1991: 76-114]. Однако влияние бурного развития естественных наук на традиционные религиозные и нравственные ценности, принятые в обществе, Гончаров заметил гораздо раньше, еще в 1830-е гг.

В статье «Намерения, задачи и идеи романа “Обрыв”» он писал: «... в наше время... человеческое общество выходит из детства и заметно зреет... наука, ремесла, промышленность - делают серьезные шаги...» [Гончаров, 1952-1955. Т. 8: 210-211]. В шатких умах «выход из детства» породил эпидемию утраты «младенческой веры» - не только в чудеса, и вообще в сверхъестественное, но и в идеальное. Этот процесс нашел отражение уже в романе «Обыкновенная история», в котором впервые изображен носитель позитивной философии, без волоховских крайностей, Петр Иванович Адуев. Он вовсе не нигилист, но как раз представитель удушающего "равнодушия» к идеалам и религии в жизни. О разрушении интимно-семейных отношений Гончаров выскажется как публицист в 1870-е гг. («В общественных, политических, национальных вопросах сентименты давно изгнаны, наконец и в частных, интимных отношениях - их заменяют тоже компромиссы и т. п.!» [Гончаров, 2000: 272]), но как художник он показал это еще в 1840-е гг. в своем первом романе. Столкновению двух жизненных философий в лице дяди и племянника Адуевых Гончаров придал тот расширительный смысл, который ясно прочитывается и во «Фрегате “Паллада"», и в «Обрыве». Предметом внимания художника здесь был не только частный конфликт времени, отмеченный В. Г. Белинским в письме к В. П. Боткину («Я уверен, что тебе повесть эта сильно понравится. А какую пользу принесет она обществу! Какой она страшный удар романтизму, мечтательности, сентиментальности, провинциализму!»), но и глобальный конфликт тысячелетнего мирового разлома, происходящего на глазах современников Гончарова в XIX в. Романисту дано было почувствовать необычайную трагичность своего времени, с неизвестной (но ему всегда хотелось верить, что - оптимистичной, ибо он верил в Божий Промысел о человечестве) перспективой развития событий. История человечества разделилась в его сознании на две неравные половины: от патриархального «золотого века» до современности, в которой начинает зарождаться нечто новое, основанное на рационализме восприятия жизни, на основе 
научного мировоззрения. Разлом истории, которую Гончаров измеряет тысячелетней мерой, автор «Обыкновенной истории» остро почувствовал в то время, когда в русском обществе еще не было и мысли о масштабности происходящего. Современная литература сосредоточилась в то время на «злобе дня» более частного порядка (крепостное право, эмансипация женщин, свобода печати и пр.). Гончаров никогда не игнорировал острые конфликты современности, но подача их в его произведениях отличалась более спокойным и объективным (многие говорили о «равнодушии») тоном потому, что он видел и показывал их в незаметном для других, но чрезвычайно важном для себя свете тысячелетнего перелома истории. Этот тон определялся высотой исторического измерения, который выразился, например, в таком пассаже из «Обломова»: «И на Выборгской стороне, в доме вдовы Пшеницыной, хотя дни и ночи текут мирно, не внося буйных и внезапных перемен в однообразную жизнь, хотя четыре времени года повторили свои отправления, как в прошедшем году, но жизнь все-таки не останавливалась, всё менялась в своих явлениях, но менялась с такою медленною постепенностию, с какою происходят геологические видоизменения нашей планеты: там потихоньку осыпается гора, здесь целые века море наносит ил или отступает от берега и образует приращение почвы» [Гончаров, 1997-2014. Т. 4: 374].

По Гончарову, «сентименты» изгнаны из личного и общественного сознания потому, что, благодаря бурному развитию науки и общества, пропала «детскость веры». Лучше всего эта мысль выражена в неотправленном письме к философу Владимиру Соловьеву после прочтения его книги «Чтения о Богочеловечестве. На склоне лет Гончаров писал: «Да, нельзя жить человеческому обществу этими добытыми результатами позитивизма... надо обратиться к религии, говорите Вы (и все мы с Вами тоже)... надо обратиться к другому авторитету, от которого убежали горделивые умы, к авторитету миродержавному. Но как? Чувства младенческой веры не воротишь взрослому обществу: основания некоторых библейских сказаний с мифологическими сказаниями греческой и других мифологий - (не говоря уже о новейшей науке) подорвали веру в чудеса - и развившееся человеческое общество откинуло все так называемое метафизическое, мистическое, сверхъестественное» [Гончаров, 1994: 348-349].

Чтобы убедиться в том, что главная мысль Гончарова едина от 1840$\mathrm{x}$ гг. до конца его творческого пути, приведем хотя бы отрывок из «Обык- 
новенной истории», на который обычно не обращают внимания. Характерно, что здесь Гончаров пользуется той же лексикой, что и в письме к В. Соловьеву, написанному предположительно в 1881-1882 гг. Напомним, что Александр Адуев, разочарованный в Петербурге, возвращается в родные Грачи, заходит в церковь и там предается размышлениям. "..."Пока в человеке кипят жизненные силы, - думал Александр, - пока играют желания и страсти, он занят чувственно, он бежит того успокоительного, важного и торжественного созерцания, к которому ведет религия... он приходит искать утешения в ней с угасшими, растраченными силами, с сокрушенными надеждами, с бременем лет..." [Гончаров, 1997-2014. Т. 1: 443].

Мало-помалу, при виде знакомых предметов, в душе Александра пробуждались воспоминания. Он мысленно пробежал свое детство и юношество до поездки в Петербург; вспомнил, как, будучи ребенком, он повторял за матерью молитвы, как она твердила ему об ангеле-хранителе, который стоит на страже души человеческой и вечно враждует с нечистым; как она, указывая ему на звезды, говорила, что это очи Божиих ангелов, которые смотрят на мир и считают добрые и злые дела людей, как небожители плачут, когда в итоге окажется больше злых, нежели добрых дел, и как радуются, когда добрые дела превышают злые. Показывая на синеву дальнего горизонта, она говорила, что это Сион... Александр вздохнул, очнувшись от этих воспоминаний.

“Ах! если 6 я мог еще верить в это! - думал он. - Младенческие верования утрачены (курсив мой - В. М.), а что я узнал нового, верного?.. ничего: я нашел сомнения, толки, теории... и от истины еще дальше прежнего... К чему этот раскол, это умничанье?.. Боже!.. когда теплота веры не греет сердца, разве можно быть счастливым? Счастливее ли я?”

Всенощная кончилась. Александр приехал домой еще скучнее, нежели поехал» [Гончаров, 1997-2014. Т. 1: 443-444].

Размышления Александра Адуева носят автобиографический характер, Гончаров ощущал утрату «младенческих верований» не только как общественную, но и как личную драму. Наиболее характерно его настроения выплеснулись в строках письма к А. Ф. Кони от 30 июня 1886 г.: «Я с умилением смотрю на тех сокрушенных духом и раздавленных жизнью старичков и старушек, которые, гнездясь по стенке в церквах, или в своих каморках перед лампадой, тихо и безропотно несут свое иго и видят жизнь и над жизнью высоко только крест и Евангелие, одному этому верят и на одно надеются! Отчего мы не такие. “Это глупые, бла- 
женные", - говорят мудрецы мыслители. Нет - это люди, это те, которым открыто то, что скрыто от умных и разумных. Тех есть Царствие Божие и они сынами Божиими нарекутся!» [Гончаров, 2000: 499]. При этом заметим, что на протяжении всей жизни Гончаров как христианин не утрачивает окончательной связи с «младенческими верованиями», хотя и тщательно скрывает это от окружающих, говоря, чаще всего (например, в письмах), об иных сторонах современного религиозного сознания. Последний раз, причем в автобиографическом ключе, он изобразил носителя «младенческой веры» в пономаре Ереме в новелле «Уха», написанной за несколько недель до смерти [Мельник, 2017].

К этой же проблеме обращается писатель и во «Фрегате “Паллада"», где вопрос о завершении тысячелетней истории господства «мифа» и «веры», с одной стороны, и о начале новой (научно-промышленной) эпохи человеческой истории - с другой, представлен в культурно-цивилизационном освещении. Гончаров условно делит историю человечества на два периода: «мифопоэтическую» («детство») и «культурно-цивилизационную» или «творческую» («выход из детства»). Эта своеобразная историософия упомянута в первой главе «Фрегата», где писатель объясняет мотивы своего неожиданного для многих решения совершить кругосветное плавание: «Всё было загадочно и фантастически прекрасно в волшебной дали: счастливцы ходили и возвращались с заманчивою, но глухою повестью о чудесах, с детским толкованием тайн мира (курсив мой $-B . M$.$) . Но вот явился человек, мудрец и поэт, и озарил таинствен-$ ные углы. Он пошел туда с компасом, заступом, циркулем и кистью, с сердцем, полным веры к Творцу и любви к Его мирозданию. Он внес жизнь, разум и опыт в каменные пустыни, в глушь лесов и силою светлого разумения указал путь тысячам за собою. “Космос!” Еще мучительнее прежнего хотелось взглянуть живыми глазами на живой космос. "Подал бы я, - думалось мне, - доверчиво мудрецу руку, как дитя взрослому, стал бы внимательно слушать, и, если понял бы настолько, насколько ребенок понимает толкования дядьки, я был бы богат и этим скудным разумением"...» [Гончаров, 1997-2014. Т. 2: 10].

В своей книге Гончаров наблюдает одновременно все исторические эпохи, от античного «золотого века» (идиллическая жизнь на Ликейских островах, «спящая» Япония и пр.) до современного развитого государства (Англия, американцы в разных частях света), что дает ему повод вновь и вновь возвращаться к любимой мысли о переломе тысячелетней 
истории, совершающемся на глазах его современников. Но во «Фрегате “Паллада"», в силу жанровых особенностей книги и необходимости дать описание путешествия, проблема кризиса религиозного сознания человечества не выражена столь же явно как в «Обыкновенной истории» или в «Обрыве». Зато получает подробную и завершенную историософскую аргументацию оптимистический взгляд Гончарова на перспективу нового этапа человеческой истории. Исторический оптимизм романиста зиждется на его представлении о том, что научный и технический прогресс не только не входят в противоречие с Божьим Промыслом о человечестве, но способствуют его реализации. Автор путешествия развивает философию истории в духе русских мыслителей Серебряного века, рассматривая человечество как со-работника Творцу, Который повелел человеку «насадить землю», «превратить пустыню в сад».

Оптимизм книги обусловлен тем, что, в отличие от романов, Гончаров говорит здесь не о человеке, а о человечестве. Проблема утраты «младенческой веры», «идеалов», «сентиментов» и, так сказать, первичной, «материнской» основы существования (что с новой силой вспыхнет в «Обломове») во «Фрегате» затрагивается в основном косвенно, хотя и не снята с повестки дня (изображение «цивилизационной избыточности» в жизни Лондона). Зато здесь приобретает конкретность важная мысль, которая, словно купол, завершает архитектуру размышлений Гончарова на тему «человек и Бог». Это мысль о «замысле Бога» о человеке и человечестве, о конечных целях исторической деятельности, доступных пониманию человека, мысль о том, что человечество призвано исполнить важную миссию: «насадить красоту» в Божьем Саду и реализовать себя как со-работника Бога, как со-Творца, или, говоря словами самого романиста, «возвратить Творцу плод брошенного Им зерна» ${ }^{1}$ В своей книге путешествия Гончаров и показывает про-

${ }^{1}$ Сходные мысли высказывал, хотя и позже, например, В. С. Соловьев, который в статье «Об упадке средневекового миросозерцания» (1891) писал: «... осуществление самого Царства Божия зависит не только от Бога, но и от нас, ибо ясно, что духовное перерождение человечества не может произойти помимо самого человечества... оно есть дело, на нас возложенное, задача, которую мы должны разрешать» [Соловьев, 1990: 115-116]. Корни идеи о творческой миссии человечества кроются в немецкой философии. Например, согласно И. Фихте, в основе всего существующего лежит абсолютный разум, сверхиндивидуальный субъект, творческая деятельность которого может реализоваться только через человека. 
буждение человечества к облагораживающей деятельности, к украшению земли и человеческой души. Говоря об освоении Сибири русскими людьми, Гончаров открыто выражает свою мысль, поднимаясь до высот религиозной философии: «И когда совсем готовый, населенный и просвещенный край, некогда темный, предстанет перед изумленным человечеством, требуя себе имени и прав, пусть тогда допрашивается история о тех, кто воздвиг это здание... Это те же люди, которые в одном углу мира подали голос к уничтожению торговли черными, а в другом учили алеутов и курильцев жить и молиться - и вот они же создали, выдумали Сибирь, населили и просветили ее, и теперь хотят возвратить Творцу плод брошенного Им зерна» [Гончаров, 1997-2014. T. 2: 677-678]. Поэтому большое место в книге занимает тема миссионерства как цивилизаторской работы, перед нами разворачивается широкая картина изменения мира, все более могучего распространения христианства и внешней формы его бытования в мире - европейской (христианской) цивилизации, ибо по Гончарову, «... нет другой uзивилизации, кроме христианской, все прочие религии не дают человечеству ничего, кроме мрака, темноты, невежества и путаницы» [Гончаров, 1952-1955. Т. 8: 71]. Во время путешествия Гончаров как никогда ощутил единство христианства и цивилизации, культуры.

Показывая государства и народы, находящиеся на разных стадиях цивилизационного развития, Гончаров убеждает в неизбежности «пробуждения от сна» или «повзросления» человечества в целом, прощания человечества с эпохой «мифологии». Область его интересов - не только география, но и философия «космоса» в понимании А. Гумбольдта (к этому времени Гончаров, несомненно, уже прочел первые два или три тома «Космоса» Гумбольдта - первый том вышел в 1845 г.) ${ }^{1}$. Возможно, Гумбольдт, пользовавшийся непререкаемым авторитетом в

\footnotetext{
1 Замечание в письме к К. Д. Кавелину от 25 марта 1874 г. о том, что при строгом подходе даже от Гумбольдта «можно пожелать большей подготовки, нежели ту, какую он имел» [Гончаров, 1952-1955. Т. 8: 464], свидетельствует в пользу предположения, что Гончаров был знаком с трудами немецкого ученого, по крайней мере, с популярно написанным «Космосом». При этом оговорка Гончарова имеет подоплекой то, что Гумбольдт был стихийным материалистом и объяснял развитие природы ее внутренними силами и причинами, с чем Гончаров никогда согласиться не мог, считая, что пути веры и науки «параллельны и бесконечны» и что наука ни в коем случае не заменяет веры.
} 
мировой науке, и был тем «мудрецом и поэтом», которого Гончаров хотел бы взять за руку, чтобы идти за ним в познании мира. Но «космос» для Гончарова обнаруживает не столько его несомненную любовь к астрономии, сколько его философию жизни, в основе которой для него лежит религия и сердце, «полное веры к Творцу и любви к Его мирозданию». Вспомним, что «когда Платон, Ксенофон и Аристотель говорят о небесах как о kosmov, они имеют в виду не непосредственное созерцание ночного неба, но всеобъемлющий порядок вещей, в котором движение небесных тел предстает только как наиболее заметное и наиболее величественное его проявление» [Charles H. Kahn]. Задача изображения современного представления о «космосе» - это один из важнейших духовных и философских центров "Фрегата “Паллады”», притягивающий к себе всю эмпирику разнородных наблюдений автора-путешественника. Слово «космос» здесь поставлено во вполне земной контекст: путешественник хотел бы, вслед за А. Гумбольдтом, постигнуть единство, всеобщую связь элементов «космоса» родной планеты, увидеть ее всю целиком и осознать единство происходящих исторических процессов. Это и было сделано в книге «Фрегат “Паллада"», все очерки которой объединены не только образом автора, но и постоянно продвигаемой историософской мыслью, исходной точкой которой является «вера Творцу и любовь к Его мирозданию».

Гончаров противополагает две глобальные эпохи развития человечества во многих своих произведениях, говорит об этом противопоставлении в письмах и статьях, окрашивая свои размышления то в пафосно-оптимистические, то в драматические тона. Чрезвычайно широк разброс тем и проблем, которые при этом затрагивает писатель. Это и философия, и история, и эстетика, и нравственность, и наука, и религия, и психология, и социум и пр. Даже развитие жанровых систем в литературе он склонен рассматривать под этим углом зрения. Так, в статье «Намерения, задачи и идеи романа “Обрыв”» он писал: «Европейские литературы выили из детства (курсив мой - В. М.) - и теперь ни на кого не подействует не только какая-нибудь идиллия, сонет, гимн, картинка или лирическое излияние чувства в стихах, но даже и басни мало, чтобы дать урок читателю. Это все уходит в роман, в рамки которого укладываются большие эпизоды жизни, иногда целая жизнь, в которой, как в большой картине, всякий читатель найдет что-нибудь близкое и знакомое ему. Поэтому роман и стал почти единственной 
формой беллетристики, куда не только укладываются произведения творческого искусства, как, например, Вальтера Скотта, Диккенса, Теккерея, Пушкина и Гоголя, но и не художники избирают эту форму, доступную массе публики, чтоб провести удобнее в большинство читателей разные вопросы дня или свои любимые задачи: политические, социальные, экономические» [Гончаров, 1952-1955. Т. 8: 211].

Выявление главного предмета художественного исследования Гончарова показывает, что он более других писателей-современников всматривался в процесс развития науки и техники и глубоко анализировал его влияние на сознание и нравственность современного человека, обращая особенное внимание на те изменения, которые происходили в области религиозного сознания. Определенную роль в серьезном отношении писателя к науке и технике сыграл его крестный отец, Николай Николаевич Трегубов, заменивший осиротевшим Гончаровым родного отца. Е. Ляцкий в свое время отметил: «Хотя Трегубов и причислял себя к масонам, но едва ли натура его была склонна к мистицизму. Напротив, все, что мы знаем, дает основание предполагать в нем человека высшей степени положительного ума, отдававшего предпочтение наукам точным, знанию определительному и наглядному» [Ляикий: 15]. Е. Ляцкий пишет, что Трегубов был «хорошим математиком» и любил основанные на математике «прикладные науки - физику, астрономию, космографию» [Ляикий: 16]. В очерке «На родине» Гончаров вспоминал: «Образование его не ограничивалось техническими познаниями в морском деле, приобретенными в морском корпусе. Он дополнял его непрестанным чтением - по всем частям знания, не жалел денег на выписку из столиц журналов, книг, брошюр. Как, бывало, прочитает в газете объявление о книге, которая, по заглавию, покажется ему интересною, сейчас посылает требование в столицу» [Гончаров, 1952-1955. Т. 8: 234]. Трегубов беспокоился об образовании маленького Вани и стремился передать ему свою любовь к техническим знаниям: «... по мере того как он старел, а я приходил в возраст, между мной и им установилась - с его стороны передача, а с моей - живая восприимчивость его серьезных технических познаний в чистой и прикладной математике. Особенно ясны и неоцененны были для меня его беседы о математической и физической географии, астрономии, вообще космогонии, потом навигации. Он познакомил меня с картой звездного неба, наглядно объяснял движение планет, вращение земли, все то, чего не умели или не хотели сделать мои школьные наставники. Я увидел ясно, что они 
были дети перед ним в этих технических, преподанных мне им уроках. У него были некоторые морские инструменты, телескоп, секстант, хронометр. Между книгами у него оказались путешествия всех кругосветных плавателей, с Кука до последних времен. Я жадно поглощал его рассказы и зачитывался путешествиями» [Гончаров, 1952-1955. Т. 8: 238].

Однозначно следует сказать, что Гончаров был впечатлен научным и техническим прогрессом уже к 1830-1840-м гг. - и на протяжении всей жизни внимательно следил не только за неоднозначными результатами прогресса в области общественной жизни, но и за конкретными открытиями и новшествами. А следить было за чем. Известно, что один XIX в. принес открытий и изобретений больше, чем все предшествующие столетия вместе взятые. Подсчитано, что таких открытий было более восьми с половиной тысяч, и каких! Впервые была освоена сила пара, что позволило осуществить промышленный переворот, перейти от мануфактурного производства к промышленному. Европа и Северная Америка покрылись сетью железных дорог, страны и континенты начали «сближаться». Во «Фрегате “Паллада"» Гончаров на каждом шагу отмечает все эти изменения. Например, он пишет: «Части света быстро сближаются между собою: из Европы в Америку - рукой подать; поговаривают, что будут ездить туда в сорок восемь часов, пуф, шутка конечно, но современный пуф, намекающий на будущие гигантские успехи мореплавания» [Гончаров, 1997-2014. Т. 2: 13]. Отметил писатель и превосходство пара над силой ветра. Накануне столкновений с военными флотами Англии и ее союзников он размышляет о парусных судах, которые составляли основную силу военного флота России: «Оно, пожалуй, красиво смотреть со стороны, когда на бесконечной глади вод плывет корабль, окрыленный белыми парусами, как подобие лебедя, а когда попадешь в эту паутину снастей, от которых проходу нет, то увидишь в этом не доказательство силы, а скорее безнадежность на совершенную победу... Напрасно водили меня показывать, как красиво вздуваются паруса с подветренной стороны, как фрегат, лежа боком на воде, режет волны и мчится по двенадцати узлов в час. “Эдак и пароход не пойдет!” - говорят мне. “Да зато пароход всегда пойдет”... Дело решено. Паруса остались на долю мелких судов и небогатых промышленников; всё остальное усвоило пар. Ни на одной военной верфи не строят больших парусных судов; даже старые переделываются на паровые» [Гончаров. 1997-2014. Т. 2: 26]. 
Уже в XIX в. начался выпуск первых синтетических материалов, искусственных волокон. Научные открытия в области физики, химии, биологии, астрономии, геологии, медицины следовали одно за другим. М. Фарадей открыл явление электромагнитной дуги, Д. Максвелл предпринимает исследование электромагнитных полей, разрабатывает электромагнитную теорию света. А. Беккерель, П. Кюри и М. Склодовская-Кюри, изучая явление радиоактивности, поставили под вопрос прежнее понимание закона сохранения энергии. В 1869 г. Д. И. Менделеев открыл периодический закон химических элементов. В биологии появляются теории клеточного строения всех организмов, разрабатываются основы генетики. Основываясь на исследованиях в области физиологии высшей нервной деятельности, И. П. Павлов разработал теорию условных рефлексов. В это же время возникает как таковое машиностроение (производство машин с помощью самих машин). Железо и сталь повсеместно вытесняют дерево. Уже в 1803 г. появляется первый автомобиль с паровым двигателем и в это же время строятся первые пароходы, а вскоре человечество начинает пользоваться электрическим телеграфом и телефоном. В 1863 г. появилась первая подземная железная дорога («метрополитен»), а к концу века метро функционировало уже в Лондоне, Париже, Нью-Йорке, Будапеште, Париже и других городах.

Особо следует сказать о Ч. Дарвине, чьи труды «Происхождение видов» и «Происхождение человека» произвели подлинную революцию в науке. Эти книги иначе, чем христианское учение, трактовали возникновение мира и человека. Это породило общеевропейскую дискуссию, которая не прошла мимо внимания Гончарова. Характерно, что Гончаров сумел объективно оценить значение действительно важных открытий Ч. Дарвина. В статье «О пользе истории» он писал: «Новая... наука в лице Дарвина и других создала закон о наследственности, который и прежде чувствовали и признавали все мыслящие люди... Тот же духовный закон наследственности проходит по всей истории» [Гончаров, 1965] ${ }^{1}$. Весьма характерно, что в параллель с «материальной» наследственностью, открытой английским ученым, Гончаров говорит о «духовном законе наследственности».

\footnotetext{
1 Идеи Гончарова отчасти перекликаются с мыслями А. К. Толстого из его стихотворения «Послание к М. Н. Лонгинову о дарвинисме» (1872), в котором поэт не защищает дарвинизм, но говорит о свободном самовыражении науки, о необходимости не противопоставлять веру и науку, а сочетать их в стремлении к истине.
} 
Таким образом, жизнь человека в XIX в. радикально изменилась. Пространство и время стали в большей мере подчиняться человеку, благодаря чему менялась на глазах самая философия жизни, в том числе и отношение к традиционным религиозным ценностям.

По читательским интересам Гончарова видно, что в первую очередь его интересовала естественная история. Хранящаяся на родине писателя, в Ульяновском дворце книги, личная библиотека, уцелевшая лишь в незначительной своей части, содержит книги достаточно крупных европейских ученых и популяризаторов науки XIX в.: Д. Араго ${ }^{1}$, Д. Тиндаля ${ }^{2}$, Л. Фигье ${ }^{3}$, К. Фламмариона ${ }^{4}$, Д. Дрейпера ${ }^{5}$ и др. [См.: Никитина, Сукайло, Кукуева, 1987].

Наибольший интерес Гончаров испытывал к открытиям в области астрономии. Причем в его библиотеке были не только научно-популярные, но и собственно научные книги по астрономии, в частности, кни-

${ }^{1}$ Доминик Франсуа Жан Араго (1786-1853) - французский физик и астроном, сотрудничал с А. Гумбольдтом, автор множества открытий, его имя внесено в список величайших учёных Франции.

2 Джон Тиндаль (1820-1893) - английский физик, член Лондонского королевского общества, сотрудник Фарадея, автор научно-популярных книг, переведённых на многие языки мира. В библиотеке Гончарова имелась его книга «Речи и статьи» [Тиндаль, 1875]. Характерно, что книги Тиндаля были и в библиотеке Ф. М. Достоевского.

3 Луи Фигье (1819-1894) - французский химик, автор работ по истории науки. У Гончарова была как минимум одна из его популярных книг [Figuier L, 1875].

${ }^{4}$ Камиль Николя Фламмарион (1842-1925) - французский астроном; выдающийся популяризатор науки, чьи книги по астрономии издаются до сих пор, в т. ч. в России. Открытия Фламмариона связаны с наблюдением двойных и кратных звёзд. Также он изучал вопросы земной атмосферы, климатологии и вулканологии. В библиотеке Гончарова находились книги ученого [Flammarion C. 1869, 1872, 1873. См. об этом: Никитина, Сукайло, Кукуева, 1987: 111-112].

5 Джон Уильям Дрейпер (1811-1882) - американский ученый и историк науки. Первый президент американского химического общества, основатель медицинской школы Нью-Йоркского университета. Гончаров, конечно, был знаком с его книгой «Конфликт науки и религии» [Dreper J, 1874]. Возможно, читал он и его книгу «История умственного развития Европы» [Dreper J, 1862], которая пользовалась популярностью в России в середине 1860-х гг. и была переведена на русский язык в 1866 г. Дрейпер был приверженцем эволюционных идей Ч. Дарвина и Г. Спенсера. 
га итальянского астронома Секки Анджело ${ }^{1}$ (1818-1878) о поверхности Солнца [Secchi A, 1870]. Составители описания библиотеки Гончарова отмечают: «Присутствие книги Секки в библиотеке И. А. Гончарова несколько неожиданно: книгу Секки никак не назовешь популярной ни по языку, ни по содержанию. Видимо, любознательность и интерес Гончарова к последним достижениям в астрономии побороли боязнь “строгих научных форм”» [Никитина, Сукайло, Кукуева, 1987: 117]. Любопытно, что космическая тема звучит и в одном из последних произведений писателя «Май месяц в Петербурге»: «Тот лет десять все составляет какой-то лексикон восточных языков, да кроме того занимается астрономией, перечел все авторитеты от Ньютона, Гершелей, ${ }^{2}$ до какого-нибудь Фламмариона, и все хочет добиться, есть ли жители на Венере, $\mathrm{Mapce}^{3}$ и других планетах, какие они, что делают и прочее?» [Гончаров, 1952-1955. Т. 7: 426]. Последние вопросы родились у Гончарова под влиянием К. Фламмариона, который издал целый ряд замечательных научно-популярных книг: «Миры воображаемые и миры реальные» (1865), «Небесные чудеса» (1865), первый популярный учебник по астрономии, «История неба» (занимательная история астрономии, 1867). Была издана целая серия его научно-популярных лекций «Этюды по астрономии» (к 1880 г. вышло девять томов).

Кстати сказать, этот интерес Гончарова к астрономии совершенно не случаен: писатель мог бы обнаружить свои собственные мысли о религиозном кризисе человечества в трудах К. Фламмариона. Характерно, что они выражают мысли о религиозном кризисе человечества почти одними и теми же словами. Вопрос о том, что жизнь возможна не только на Земле, должен был, в числе других подобных, породить

\footnotetext{
${ }^{1}$ Секки Анджело (1818-1878) - итальянский астроном, один из основоположников звездной спектроскопии. С 1877 г. член-корреспондент Петербургской Академии Наук.

2 Речь идет о семье астрономов Гершелей. Во-первых, это Уильям Гершель (1738-1822) - выдающийся английский астроном немецкого происхождения. Прославился открытием планеты Уран, а также двух её спутников - Титании и Оберона. Во-вторых, это его сестра Каролина Гершель (1750-1848), сделавшая заметные астрономические открытия. В-третьих, это Джон Гершель (1792-1871) - английский астроном и физик, сын Уильяма Гершеля.

3 Фламмарион много сил посвятил исследованию Марса и написал книгу об условиях обитания на ней [Фламмарион, 1909].
} 
кризис религиозного сознания. Однако ученые, не потерявшие веры, искали такой ответ на этот вопрос, который не разрушал бы традиционного религиозного мышления, а примирял его с наукой, о чем много думал и сам автор «Обрыва». В предисловии к роману он писал: «Уяснение религии, даже самое отрицание ее началось вместе с религией и идет параллельно. Только пылкой юности позволительно мечтать, что эти два параллельные потока уже сошлись у ней под ногами. В спорах об этом выясняются истины, выигрывает наука, мысли, философия, а религия не теряет своей власти над большинством. Источник знания неистощим: какие успехи ни приобретай человечество на этом пути, впереди все будет бездна неведения - все людям будет оставаться искать, открывать и познавать... Мыслители говорят, что ни заповеди, ни евангелие ничего нового не сказали и не говорят, тогда как наука прибавляет ежечасно новые истины. Но в нравственном развитии дело состоит не в открытии нового, а в приближении каждого человека и всего человечества к тому идеалу совершенства, которого требует евангелие, а это едва ли не труднее достижения знания. Если путь последнего неистощим и бесконечен, то и высота человеческого совершенства по евангелию так же недостижима, хотя и не невозможна! Следовательно - и тот и другой пути параллельны и бесконечны! И то и другое одинаково трудно одолимы» [Гончаров. 1952-1955. T. 8: 156-157]. Во введении к книге «Многочисленность обитаемых миров» (1862) Фламмарион, как и Гончаров, размышлял о современном кризисе, причем в стилистике «Необыкновенной истории» и гончаровских писем: «Если мы внимательно вглядимся в духовную жизнь современного человечества, то мы увидим, что человек утратил свою прежнюю веру, а с ней и безмятежный душевный покой, которым он когда-то наслаждался; что мы живем среди борьбы противоречивых мыслей и что обеспокоенное человечество ищет философию, которая создала бы прочную религиозную основу для развития и осуществления его надежд... человек, обессиленный сомнениями, теряет сознание и падает в объятия скептицизма. Завершено дело разрушения!.. Прошлое умерло; новая философия еще не родилась, она еще скрывается в хаосе творчества. Дух современного человечества живет в противоречии с самим собой, он распадается сам в себе. Природоведение, этот могучий властелин нашего времени, руководящий прогрессом, никогда еще не был так чужд всякой философии, как именно теперь. Во главе есте- 
ственных наук стоят люди, которые совершенно произвольно отрицают бытие Божие...» [Фламмарион, 1908: 3-4].

Писатель был в курсе развития современной науки и потому, что ему приходилось следить всем этим и по своим служебным обязанностям цензора. При этом его интересовали не только отдельные открытия, но прежде всего философия современной науки и ее влияние на традиционные институты общества: религию, нравственность и пр. Несомненно признавая научный и технический прогресс как положительное явление, романист прекрасно понимал относительность могущества науки, вовсе не отменяющей религиозных ценностей, хотя и воздействующей в этом плане на незрелые умы. В том же предисловии к «Обрыву» он замечал: «Нельзя жертвовать серьезными практическими науками малодушным опасениям незначительной части вреда, какая может произойти от свободы и широты ученой деятельности. Пусть между молодыми учеными нашлись бы такие, которых изучение естественных или точных наук привело бы к выводам крайнего материализма, отрицания и т. п. Убеждения их останутся их личным уделом, а учеными усилиями их обогатится наука, как некогда исследованиями алхимиков и астрологов, добивавшихся открытия философского камня и тайн читать будущее по звездам, обогатились химия и астрология» [Гончаров. 1952-1955. Т. 8: 156].

Принципиально вопрос о соотнесенности современной науки и религиозного сознания был решен Гончаровым еще до написания «Обыкновенной истории». С тех пор его воззрения принципиально не менялись. В 1881 г. выходит уже упомянутая книга В. Соловьева «Чтения о Богочеловечестве», в которой Гончаров нашел сходные для себя мысли, чем и было вызвано его письмо к философу. В своей книге В. Соловьев подчеркивал, что центральный момент современной духовной жизни - это «стремление организовать человечество вне безусловной религиозной сферы». Автор «Чтений о Богочеловечестве» отмечал, что «этим стремлением характеризуется вся современная цивилизация» [Соловьев, 1881: 3]. Логика книги подсказывала, что укрепить в обществе расшатанные основы традиционного религиозного мышления уже невозможно, если действовать лишь методом огульного и прямолинейного отрицания успехов естественных наук и позитивизма. «Чтения о Богочеловечестве» представляли собою попытку синтезировать религию и научный эмпиризм во имя осуществления на земле христианского идеала. Причем именно религия выступала в этом синтезе на 
первый план, хотя и была «научно» оснащена [Лосев, 1983: 186].

Гончаров, судя по его письму-рецензии, согласен, во всяком случае, с тем, что религия и наука не должны противостоять друг другу. Он утверждает: «Вера - не смущается никакими “не знаю" - и добывает себе в безбрежном океане все, что ей нужно. У ней есть одно единственное и всесильное для верующего орудие - чувство.

У разума (человеческого) ничего нет, кроме первых, необходимых для домашнего, земного обихода, знаний, т. е. азбуки всеведения. В перспективе, весьма туманной, неверной и далекой - у дерзких пионеров науки есть надежда дойти когда-нибудь до тайн мироздания надежным путем науки.

Настоящая (т. е. современная - B. М.) наука мерцает таким слабым светом, что пока дает только понятие о глубине бездны неведения. Она, как аэростат, едва взлетает над земной поверхностью и в бессилии опускается назад» [Гончаров, 1994: 348]. Любопытно, что и Достоевский сходным образом отзывался о состоянии современной ему науки: «Наука человеческая еще в младенчестве, почти только начинает дело...» [Достоевский. 1972-1988. Т. 22: 33].

Подчеркнем, что мировоззрение Гончарова, его отношение к науке и религии в их соотнесенности, сложилось не позднее середины 1840-х гг., и в основных чертах, вопреки установившемуся в гончарововедении мнению о резком «поправении» писателя в 1860-1870-е гг., принципиально не менялось. Поражает как раз ранняя религиозная и философская зрелость Гончарова, который опередил многих своих современников в подходе к важнейшей для XIX в. проблеме: как жить в условиях, когда «чувства младенческой веры не воротишь взрослому обществу» [Гончаров, 1994: 349].

Очевидно, что еще во времена обучения в Московском университете, Гончаров задумался о соотнесенности науки и религиозного сознания как общественной проблемы, захватившей в свою орбиту не последние годы и десятилетия, а целое тысячелетие. Уже в университете начинали закладываться основы мировоззрения Гончарова, уже там, на лекциях С. П. Шевырева, он должен был быть поражен художественным экспериментом А. Данте в его трехчастной «Божественной комедии»: тем, что произведение великого итальянца давало цельное и законченное на тот момент представление о мироздании, согласуясь с последними достижениями науки, а также величавым, заложенным в 
самую архитектонику комедии, способом выражения авторского идеала. Шевырев в своей диссертации справедливо писал: «... мир представлен у него по принятым положениям Космологии его времени. Мысли его о земле и небе не суть ни создания его собственного воображения, ни поверья простого народа, а знания, принятые учеными века» [Шевырев, 2010: 93]. Шевырев был безусловным поклонником Данте и написал первую в России диссертацию о нем, опубликованную в 1833-1834 гг. [Шевырев, 1834: 118-180]. Вместе с тем, полный перелом в отношении творчества Данте совершился в то время лишь недавно. Еще в 1822 г. профессор Московского университета А. Мерзляков в своем учебнике указывал на «неправильный и часто противный здравому рассудку состав» «Божественной комедии» [Мерзляков, 1822: 219]. Это были отголоски уничижительных оценок «Божественной комедии» из уст представителей западного Просвещения, в частности, Вольтера, который неоднократно критиковал Данте. Академик М. П. Алексеев писал: «Для Вольтера... средние века представлялись эпохой заката умственной деятельности, мрака, суеверия и фанатизма; неудивительно, что и "Божественную комедию” он считал лишенной “вкуса" и полной “причудливости”: так думало и большинство его современников» [Алексеев, 1983: 158-159].

Уже в студенческие годы у будущего писателя впервые зародилась мысль о создании не отдельных произведений, а трилогии, в которой будет просматриваться «Ад» (Адуевы), «Чистилище» (Обломов: обломок, не ад, и не рай) и «Рай» (Райский). Мы уже имели возможность писать об этой «дантовской» архитектонике романной трилогии Гончарова [Мельник, 2000: 31-34; Мельник, 2008: 140-144], однако вне контекста нынешних размышлений о раннем созревании концептуальной и завершенной картины мира, в центре которой для Гончарова - БогТворец в его отношениях с человеком и человечеством. В данном случае мы говорим не столько о личной вере писателя, сколько об основах его миропонимания; и если его личная вера претерпевала от 1830-х до 1890-х гг. заметные изменения, то мировоззрение Гончарова в целом оставалось неизменным, и лишь дополнялось новым набором тем и проблем, выдвигаемых развитием русской жизни. Эти темы и проблемы имели частный характер в сложившейся картине мироздания, они органично вписывались и находили свое место в ней, не меняя принципов и основ философии жизни романиста. 
Возвращаясь к сути его художественной философии, скажем: дело не только и не столько в том, что Гончаров, едва ли не единственный в первой половине XIX в. оказался чувствительным к столь значимой проблеме, как бурное развитие науки и техники, разлом мировой истории («утрата младенческой веры» и стремительное «повзросление» человечества, конец мифопоэтического сознания и «тысячелетнего папства»). Важно, что он имел целью вырабатывать свою «программу» действия, направленную на изменение сознания современников. Первые следы этой «программы» обнаруживаются в раннем очерке «Иван Савич Поджабрин» (1842), а затем в художественно-философском эссе «Письма столичного друга к провинциальному жениху» (1848). В основе исторического оптимизма Гончарова и его надежды на то, что человечество переживет этот «вихрь, момент жаркой схватки», преодолеет возникший исторический «обрыв», не отойдет от религиозных ценностей, лежит не только его личная вера в благой Божий Промысел о человечестве, но и его представление о роли «красоты» в жизни человека. Это представление также сформировалось весьма рано - в годы обучения в университете, прежде всего на лекциях Н. Н. Надеждина, который, по словам писателя, заменял студентам «десяток профессоров». Именно там, серьезно изучая памятники античной культуры и ее интерпретаторов, прежде всего И. Винкельмана, Гончаров впервые начал постигать нравственную силу и философское наполнение пластической гармонии, симметрии и меры, придавая красоте универсальный смысл и веря в ее созидающую мощь. Религиозное сознание, по Гончарову, неразрывно связано с неосознанным и - в развитых натурах - сознательным желанием гармонии и красоты. Это хорошо просматривается в романе «Обрыв», в особенности в фигуре художника Райского, который неоднократно переживает пароксизмы наслаждения красотой - чаще пластической, но в высшие моменты своей нравственной жизни - красотой духовной, доходя до понимания связи своего желания гармонии и красоты и участия в этом желании Творца, понимания Его прямого духовного «водительства»: Райский «...с ужасом вглядывался и вслушивался в дикие порывы животной, слепой натуры, сам писал ей казнь и чертил новые законы, разрушал в себе “ветхого человека" и создавал нового <...>. Он, с биением сердца и трепетом чистых слез, подслушивал, среди грязи и шума страстей, подземную тихую работу в своем человеческом существе какого-то 
таинственного духа, затихавшего иногда в треске и дыме нечистого огня, но не умиравшего и просыпавшегося опять, зовущего его, сначала тихо, потом громче и громче, к трудной и нескончаемой работе над собой, над своей собственной статуей, над идеалом человека» [Гончаров, 1997-2014. Т. 7: 553-554]. Райский, пытаясь создавать собственную «статую», т. е. приблизиться к «идеалу», руководствуется чувством красоты: «С тайным, захватывающим дыхание ужасом счастья видел он, что работа чистого гения не рушится от пожара страстей, а только останавливается, и когда минует пожар, она идет вперед, медленно и туго, но всё идет <...>.

Пробегая мысленно всю нить своей жизни, он припоминал, какие нечеловеческие боли терзали его, когда он падал, как медленно вставал опять, как тихо чистый дух будил его, звал вновь на нескончаемый труд, помогая встать, ободряя, утешая, возвращая ему веру в красоту правды и добра и силу - подняться, идти дальше, выше...

Он благоговейно ужасался, чувствуя, как приходят в равновесие его силы, и как лучшие движения мысли и воли уходят туда, в это здание, как ему легче и свободнее, когда он слышит эту тайную работу и когда сам сделает усилие, движение, подаст камень, огня и воды» [Гончаров. 1997-2014. Т. 7: 554].

Райский показан здесь как человек, руководимый в своем стремлении к идеалу Святым Духом (а именно процесс «водительства» человека Святым Духом изображен здесь Гончаровым) и собственной потребностью в красоте. Главная внутренняя тема романа - созидание человеческой «статуи», «идеала», «разрушение в себе “ветхого человека” и создание нового». В этом смысле роман «Обрыв» - произведение самое патетическое в творчестве Гончарова, оно прямо соответствует третьей части «Божественной комедии» Данте - «Раю». Оканчивая роман, писатель признавался в письме к М. М. Стасюлевичу: «У меня мечты, желания и молитвы Райского кончаются, как торжественным аккордом в музыке, апофеозом женщин, потом родины России, наконец, Божества и Любви... Я <..> боюсь, что маленькое перо мое не выдержит, не поднимется на высоту моих идеалов - и художественно-религиозных настроений... Но Бог даст - Вера спасет меня!» [Гончаров. 1952-1955. Т. 8: 426].

Высшая красота для автора «Обрыва» - красота духовная, хотя даже лучшие его герои, как обычные люди, редко воспаряют до нее, 
чаще же они (Адуев, Обломов, Райский и др.) - переживают падения и стремятся к красоте, замутненной страстями, самообманом и пр.

Понятие «красоты» в этом универсальном смысле Гончаров - сначала под воздействием Н. Надеждина, а потом самостоятельно - начал осмысливать еще в 1830-е гг., опираясь на труды И. Винкельмана [См.: Мельник, 1985: 112-117], Ф. Шиллера, Ф. Шеллинга. Но едва ли не более значимыми должны были оказаться для Гончарова труды английского мыслителя А. Шефтсбери, ${ }^{1}$ который первым ясно высказал главную для Гончарова мысль - о том, что нравственное начало коренится в природе человека, в частности, в его эстетических склонностях. Не менее сильное влияние оказал на его взгляды Ф. Шиллер своими «Письмами об эстетическом воспитании человека». По мнению Шиллера, «нравственность заложена не только в рациональной природе человека» и развивается не только «при помощи рассудка», но и потому, что в человеческой природе существует «эстетическое тяготение к ней» [Шиллер. 1957. Т. 6: 145]. Постоянное внимание Гончарова к шиллеровскому пониманию нравственного идеала характерно проявилось, в частности, в его письме к С. А. Никитенко от 21 августа 1866 г.: «Вы свято и возвышенно, по-шиллеровски, смотрите... на человеческую природу - и дай Вам бог до конца донести Ваши верования» [Гончаров, 1978-1980. T. 8: 314].

Впервые этот эстетический подход к морали человека зримо, почти концептуально, проявился в 1840-е гг. в «Письмах столичного друга к провинциальному жениху». Сам жанр, условно говоря, «писем о красоте» у Гончарова восходит к «Письмам об эстетическом воспитании человека» Шиллера и к «Опыту о свободе острого ума и независимого расположения духа в письме к другу» Шефтсбери. Последний же явно усваивает вместе с принципом единства нравственности и красоты конкретные представления о пластической красоте как о симметрии, пропорции в античной эстетике, что было также особенно близко Гончарову. В «Опыте о свободе острого ума и независимого расположения духа в письме к другу» Шефтсбери, предваряя гончаровские «Письма столичного друга к провинциальному жениху», говорит о «красоте чувств, изяществе движений.., любви к размеренности, к пристой-

\footnotetext{
1 Хотя Гончаров нигде не упоминает его имени, он, несомненно, был знаком с философскими трудами Шефтсбери, на что указывает его очерк «Письма столичного друга к провинциальному жениху».
} 
ности, к пропорции» [Шебтсбери, 1975: 321]. В этом любопытном по жанру произведении, напоминающем, казалось бы, о типичном «физиологическом очерке», но, по сути, являющемся философским эссе в духе Шефтсбери и Шиллера, Гончаров пытается открыто решать те проблемы, которые остались в художественном подтексте его первого романа «Обыкновенная история».

Писатель уповает на то, что человечеству удастся преодолеть ослабление религиозного чувства, вызванное прорывом в области науки и техники: религиозное чувство неотделимо от стремления к красоте, глубоко заложенного в природе человека. В упомянутом письме к С. А. Никитенко он замечает: «...Эта потребность высокая, свойственная только человеческой природе и которой у животных нет» [Гончаров, 1978-1980. Т. 8: 316]. ${ }^{1}$

Красота - это «мост», соединяющий в человеке внешнее и внутреннее, «биологическое» и духовное. Причем красота духовная связана, по Гончарову, с красотой пластической. В «Письмах столичного друга к провинциальному жениху» писатель показывает, что чувство красоты присуще всем людям без исключения, хотя ее содержание трактуется человеком в зависимости от его развития: от вульгарной «моды» до красоты духовной («нечеловеческой», ангельской). Гончаров настаивает на том, что человек может развиваться, совершенствоваться и, соответственно, «восходить по ступеням» духовного, идеального понимания красоты.

Как уже сказано, Гончаров не только констатирует религиозный кризис, начиная с 1830-х гг., но и подчиняет свое творчество выработке «противоядия», проявляя себя художником с дидактическими наклонностями, который мог бы сказать вместе с Райским: «Хоть рясы и не надену, а проповедовать могу - и искренно, всюду, где замечу ложь, притворство, злость - словом, отсутствие красоты, нужды нет, что сам бываю безобразен» [Гончаров, 1997-2014. Т. 7: 38]. В этом смысле давний спор о необыкновенной объективности романиста, ${ }^{2}$ с одной

1 Эта замечательная формулировка есть буквальное цитирование слов современника Гончарова немецкого философа-естествоиспытателя и богослова Германа Ульрици (1806-1884), книги которого переводились на русский язык: «...способность созерцать прекрасное есть только у человека, но нет ее у животных...» [Цит. по: Стеллецкий, 2011. Т. 2: 192].

2 Еще В. Г. Белинский заложил эту тенденцию: «Он поэт, художник и больше ничего. У него нет ни любви, ни вражды к создаваемым им лицам, они его не веселят, не сердят, он не дает никаких нравственных 
стороны, и его хорошо скрытом дидактизме - с другой, должен быть разрешен по преимуществу в пользу последнего тезиса. Несомненно, в творчестве Гончарова мощно присутствует момент бессознательного и даже «творческого эпикуреизма», о чем он сам писал неоднократно: «Творчество - своего рода эпикуреизм, наслаждения искусства суть тоже чувственные наслаждения - как... ни оспаривайте: творчество это высшее раздражение нервной системы, охмеление мозга и напряжённое состояние всего организма...» [Гончаров, 1978-1980. Т. 8: 285]. Или: «У... сознательных писателей ум досказывает, чего не договаривает образ - и их создания бывают нередко сухи, бледны, неполны; они говорят уму читателя, мало говоря воображению и чувству. Они убеждают, учат, уверяют, так сказать, мало трогая. И наоборот - при избытке фантазии и при - относительно меньшем против таланта - уме образ поглощает в себе значение, идею; картина говорит за себя, и художник часто сам увидит смысл - с помощью тонкого критического истолкователя, какими, например, были Белинский и Добролюбов» [Гончаров 1952-1955. Т. 8: 69-70]. Позиционируя себя преимущественно как абсолютно «бессознательного художника» (он постоянно возвращался к определению Белинского), Гончаров в данном случае явно преувеличивает. В другом месте он столь же преувеличенно замечает: «Перестанет он также быть художником и в таком случае, если удалится от образа и станет на почву мыслителя, умника или моралиста и проповедника» [Гончаров, 1952-1955. Т. 8: 211-212]. Недаром подобные высказывания Гончарова вызвали реакцию И. С. Тургенева: «Не могу, кстати, не высказать своего мнения о “бессознательном и сознательном творчестве”, о “предвзятых идеях и тенденциях", о “пользе объективности, непосредственности и наивности” - обо всех этих “жалких” словах (в выражении “жалкие слова” обнаруживается адресат критики: о “жалких словах” говорит Захар в романе “Обломов” - B.M.), которые, из каких бы авторитетных уст они ни исходили, всегда казались мне общими

уроков ни им, ни читателю, он как будто думает: кто в беде, тот и в ответе, а мое дело сторона. Из всех нынешних писателей он один, только он один приближается к идеалу чистого искусства, тогда как все другие отошли от него на неизмеримое пространство - и тем самым успевают. Все нынешние писатели имеют еще нечто, кроме таланта, и это-то нечто важнее самого таланта и составляет его силу; у г. Гончарова нет ничего, кроме таланта; он больше, чем кто-нибудь теперь, поэт-художник» [Белинскиц̆, 1948. Т. 3: 813]. 
местами, ходячей риторической монетой, которая потому только не считается за фальшивую, что ее слишком многие принимают за настоящую... У нас теперь развелись сочинители, которые сами почитают себя “бессознательными творцами” и выбирают все “жизненные” сюжеты; а между тем насквозь проникнуты именно этой злополучной “тенденцией”» [Тургенев И. С. 1966. T. XII: $309-310$ ].

С другой стороны, Гончаров сам был мыслителем, «проповедником», и обижался, когда в его творчестве не видели ничего, кроме «картин»: «Иные не находили или не хотели находить в моих образах и картинах ничего, кроме более или менее живо нарисованных портретов, пейзажей, может быть живых копий с нравов - и только. За что же тут хвалить? Разве так трудно вообще для таланта, если он есть, нагромоздить в кучу лица провинциальных старух, учителей, женщин, девиц, дворовых людей и т. п.? Что за заслуга?» [Гончаров. 1952-1955. Т. 8: 69-70]. Статья «Намерения, задачи и идеи романа “Обрыв” (1876) показывает, что Гончаров был прирожденным проповедником: «На искусстве лежит серьезный долг - смягчать и улучшать человека... оно должно представлять ему нельстивое зеркало его глупостей, уродливостей, страстей, со всеми последствиями, словом - осветить все глубины жизни, обнажить ее скрытые основы и весь механизм, - тогда с сознанием явится и знание, как остеречься» [Гончаров, 1952-1955. Т. 8: $212]$. Н. И. Пруцков в своей монографии о Гончарове отмечал: «... Романист то и дело оказывался около той границы, за которой область искусства уступала место... прямому нравоучению... Вся романическая система Гончарова характеризуется оригинальным слиянием удивительной поэтичности в пластическом воспроизведении художником характеров и ситуаций с рационалистичностью в способах, приемах и формах их изображения и оценок. Создается впечатление, что он творил по вдохновению, но “укладывал” результаты своих вдохновений в рационалистические поэтические формы» [Пруцков, 1962: 7, 224].

Серьезно показывать «уродливости» и «страсти» Гончаров начал еще в «Иване Савиче Поджабрине». Казалось бы, легкий нравоописательный очерк, в котором без труда обнаруживаются нарочитые штампы сюжетов и поэтики «натуральной школы» (чиновник, снимающий квартиры и «жуирующий» жизнью), на самом деле, как и «Письма столичного друга», затрагивает существеннейший для писателя вопрос: о стремлении человека к красоте - при извращенных (на низшем, «зо- 
ологическом», о чем говорит фамилия героя, уровне духовной жизни) понятиях о ней. Гончаров питает интерес к образу Дон Жуана, на которого ориентированы многие персонажи писателя. Образ Дон Жуана в произведениях Гончарова следует рассматривать не только как доказательство его необычайной способности к масштабной типизации и возведению локальных «типов» к общемировым, но и как признак его постоянного внимания к проблеме красоты и восхождения человека через красоту от «жалкого существа» до «порядочного человека». Дон Жуанов в творчестве Гончарова немало - и в каждом разное соотношение драматического и пародийно-комического элементов [Мельник, 1990: 49-59; Отрадин, 1994: 20; Рецов, 2015: 38-46]. Иван Савич, как и Александр Адуев, это обитатель созданного Гончаровым в 1840-е гг. «Ада». Но даже в Райском серьезная сторона донжуанизма постоянно пересекается с комическим восприятием его «поисков красоты». В этом смысле Гончаров, следуя за замыслом «Божественной комедии», сохраняет лишь основную тенденцию, заложенную в архитектонике его романной трилогии, о которой он сам сказал в статье «Лучше поздно, чем никогда»: «Только когда я закончил свои работы, отошел от них на некоторое расстояние и время, - тогда стал понятен мне вполне и скрытый в них смысл, их значение - идея. Напрасно я ждал, что кто-нибудь и кроме меня прочтет между строками и, полюбив образы, свяжет их в одно целое и увидит, что именно говорит это целое? Но этого не было» [Гончаров, 1952-1955. Т. 8: 67].

Теперь, когда несколько прояснена логика творческого развития Гончарова, сформировавшаяся еще в 1830-1840-е гг., становится понятным, что романист видел упоминаемую им «идею» трилогии еще до создания «Обыкновенной истории». Б. М. Энгельгардт тонко почувствовал, что и "Фрегат “Палладу” романист писал еще до путешествия, т. е. ориентируясь на определенную уже сложившуюся идею: «... еще не выезжая из Петербурга, Гончаров знал, что и как он напишет» [Гончаров, 2000: 16]. Хотя исследователь имел в виду более частный момент («Очерки путешествия были задуманы им как продолжение “Обломова”...») и сводит дело к литературной мистификации («Литературный смысл этой мистификации выражался в борьбе с романтизмом» [Гончаров, 2000: 16]), он верно угадал дух «Фрегата “Паллады”»: в книге широко и как нигде более открыто выражено мировоззрение Гончарова, поэтому вся ее «философическая часть» сложилась в голове 
автора задолго до путешествия - и лишь конкретизировалась непосредственными наблюдениями. «Идея» у романиста сформировалась давно, она делает не только романы Гончарова единой «трилогией», но и придает всему его творчеству цельность и завершенность. «Прочесть между строками» и «связать образы в одно целое» - важнейшая задача современного гончарововедения.

Романист надеялся, что тысячелетний перелом истории (изменение религиозного сознания современного человека под влиянием бурного развития науки) будет преодолен той силой, которую заложил в природу человека Творец: это стремление к красоте. Свое творчество он посвятил изображению восхождения человека от «ада» безверия и страстей по ступеням «очеловечивания» - к высшей, духовной, красоте Христа.

В настоящей статье мы кратко коснулись лишь некоторых сторон целого комплекса проблем, встающих перед исследователем указанной в заглавии темы. Выявление главной движущей идеи гончаровского творчества, особенностей формирования его мировоззрения и творческих замыслов в 1830-1840-е гг., на наш взгляд, заставляет задуматься как о существенной переоценке Гончарова как литературной фигуры XIX в., так и о переосмыслении многих установившихся представлений о его творчестве.

\section{Список литературы}

Алексеев М. П. Сравнительное литературоведение. Л.: Наука, 1983. 448 с.

Белинский В. Г. Собр. соч. : в 3 т. Т. 3. М.: Гос. издат. худ. лит., 1948. 928 с.

Беляева И. А. «Странные сближения»: Гончаров и Данте // Изв. РАН. Сер. лит. и языка. М., 2007. Т. 66. № 2. С. 23-28.

Беляева И. А. «Тройственная поэма» русской жизни: Данте Алигьери С. П. Шевырев - И. А. Гончаров // Славянский мир: общность и многообразие. Коломна: Коломен. гос. пед. ин-т., 2007. Ч. 1. Литературовед. С. 37-40.

Богомолова Н. В. Эволюция женского характера в трилогии И. А. Гончарова // Русское литературоведение на современном этапе: / гл. ред. Ю. Г. Круглов; М.: Моск. гос. открыт. пед. ун-т им. М. А. Шолохова, 2006. Т. 1. С. 90-94.

Богомолова Н. В. Эволюция авторского мировидения в трилогии И. А. Гончарова: дисс. канд. ... филол. наук. М., 2009. 212 с.

Воробьева М. С. «Карнавальные пары» в романах И. А. Гончарова // Вестник Нижегородского университета им. Н. И. Лобачевского. Сер. Филология. 2004. № 1 (5). С. $28-32$.

И. А. Гончаров. Материалы и исследования. Литературное наследство. Т. 102. М.: Наука, 2000. 736 c.

Гончаров И. А. О пользе истории // Неделя. М., 1965. № 32. 
Гончаров И. А. Письмо к В. С. Соловьеву. Предисловие и публикация В. И. Мельника // И. А. Гончаров (Материалы международной конференции, посвященной 180-летию со дня рождения И. А. Гончарова). Ульяновск, 1994. С. 343-351.

Гончаров И. А. Полн. собр. соч.: в 20 т. Т. 1-10. СПб.: Наука, 1997-2014.

Гончаров И. А. Собр. соч.: в 8 т. М.: Худ. лит. 1952-1955.

Гончаров И. А. Собр. соч.: 8 т. М.: Худ. лит., 1978-1980.

Доманский В. А. Сады Гончарова // Доманский В. А., Кафанова О. Б., Шарафадина К. И. Литература в синтезе искусств: в 3 т. / СПб.: Гос. ун-т технол. и дизайна, 2010. Т. 1. Сад и город как текст. С. 187-223.

Достоевский Ф. М. Собрание сочинений: в 30 т. Л.: Наука, 1972-1988.

Кочетова В. Г. К вопросу о типологии характеров в произведениях И. А. Гончарова // Художественный текст: варианты интерпретации / отв. ред. В. А. Акимов. Бийск, 2006. Ч. 1. С. 281-288.

Кубасов А. В. «Мовизм» позднего Гончарова: «Май месяц в Петербурге» // Материалы VI международной научной конференции, посвященной 205-летию со дня рождения И. А. Гончарова. Ульяновск, 2017. С. 247-254.

Лосев А. Ф. Вл. Соловьев. М.: Мысль, 1983. 208 с.

Ляцикий Е. А. Роман и жизнь: Развитие творческой личности И. А. Гончарова: Жизнь и быт. 1812-1857. Прага: Пламя, 1925. 392 с.

Мельник В. И. Евангельский текст новеллы-притчи «Уха» И. А. Гончарова // Проблемы исторической поэтики. 2017. Т. 15. № 2. С. 60-80.

Мельник В. И. И. А. Гончаров: духовные и литературные истоки. М.: МГУП, 2000. 282 c.

Мельник В. И. Гончаров и православие: духовный мир писателя. М.: Даръ, 2008. $544 \mathrm{c}$.

Мельник В. И. Реализм И. А. Гончарова. Владивосток: Изд-во Дальневосточного госуниверситета, 1985. $140 \mathrm{c}$.

Мельник В. И. Тема донжуанизма в творчестве И. А. Гончарова // Метод, жанр, поэтика в зарубежной литературе. Фрунзе. Изд-во Киргизского госуниверситета. 1990. С. 49-59.

Мельник В. И. Этический идеал И. А. Гончарова. Киев: «Лыбидь», 1991. 152 с.

Мерзляков А. Краткое начертание теории изящной словесности. М., 1822. 328 с.

Недзвецкий В. А. Психологическое течение в литературе критического реализма (Тургенев, Гончаров, Писемский, Островский) // Развитие критического реализма в русской литературе: в 3 т. / отв. ред. К. Н. Ломунов. М.: Наука, 1973. Т. 2, кн. 1. Расцвет критического реализма. 40-70 гг. С. 15-149.

Никитина Н. И., Сукайло В. А., Кукуева А. И. Описание библиотеки И. А. Гончарова. Каталог. Ульяновск, 1987. 120 с.

Отрадин М. В. Проза И. А. Гончарова в литературном контексте. СПб.: Изд-во Санкт-Петербургского ун-та, 1994. 168 с.

Пруиков Н. И. Мастерство Гончарова-романиста. М.-Л.: АН СССР, 1962. 320 с.

Рецов В. В. Иван Аянов в роли «несравненного Лепорелло (к вопросу о теме Дон Жуана в романе И. А. Гончарова «Обрыв» // Известия Южного федерального университета. 2015. № 1. С. 38-46. 
Соловьев В. С. Избранное. М.: Советская Россия, 1990. 496 с.

Соловьев В. С. Чтения о богочеловечестве. М., 1881. 382 с.

Проб. Николай Стеллецкий. Опыт нравственного православного богословия в апологетическом освещении: в 3 т. Т. 2. М.: ФИВ, 2011. 736 с.

Тиндаль Д. Речи и статьи. М., 1875. 188 с.

Толстая С. А. Дневники. В 2 т. Т. 1. М.: Худ. лит., 1978. 628 с.

Тургенев И. С. Полное собрание сочинений и писем: в 28 т. Соч. Т. XII. М.-Л.: Наука, 1966. 584 с.

Фламмарион К. Многочисленность обитаемых миров. М.: Товарищество И. Д. Сытина, 1908. 240 с.

Фламмарион К. Планета Марс и условия обитания на ней. М., 1909. 234 с.

Цейтлин А. Г. Гончаров. М.: Изд-во АН СССР. 1950. 492 с.

Цейтлин А. Г. Трилогия Гончарова // Родной язык в школе. 1927. № 4. С. 95-108.

Хувилер - Фан дер Хаген А. Трилогия ли романы Гончарова? // Ivan A. Goncarov: Leben, Werk und Wirkung. Beitrage der I. Internationalen Goncarov-Konferenz. Bamberg, 8-10. Oktober 1991 / hg. von P. Thiergen. Koln, 1994. C. 73-81.

Шевырев С. П. Дант и его век. Исследование о Божественной комедии // Учен. зап. Императорского Московского университета. М.: Университетская типография, 1834. № 7. С. 118-180.

Шевырев С. П. Избранные труды. М.: Российская политическая энциклопедия, 2010. $776 \mathrm{c}$.

Шефтсбери А. Эстетические опыты. М.: Искусство, 1975. 536 с.

Шиллер Ф. Собр. соч.: в 7 т. М.: Художественная литература, 1955-1957. Т. 6. $792 \mathrm{c}$

Charles H. Kahn. Anaximander and the Originsof Greek Cosmology. ColumbiaUniversity Press, New York, 1960. Пер. М. Н. Вольфа [Электронный ресурс]. URL: https://nsu.ru/classics/Wolf/Kahn_2.htm (дата обращения: 04.07.2019)

Dreper J. History of the conflict between religion and science. New York: D. Appleton, 1874. $266 \mathrm{p}$.

Dreper J. History of the intellectual development of Europe. Paris, 1862. 544 p.

Figuier L.L' annee scientifiqe et industrielle. Paris, 1875. 856 p.

Flammarion C. La pluralite des mondes habites, etudes ou 1 on expose les conditions... Paris, $1872.366 \mathrm{p}$.

Flammarion C. Les merveilles celestas, lectures du Soir. Paris, 1869. 362 p.

Flammarion $C$. Recits de 1 infini, humaine histoire d une cjmete dans 1 infini. Paris, $1873.416 \mathrm{p}$.

Secchi A. Le Soleil: expose des principales decouvertes modernes sur la structure de cet, son influence dans l'univers et ses relations avec les autres corps celestas... Paris, 1870. $432 \mathrm{p}$.

\section{References}

Alekseev M. P. Sravnitel'noe literaturovedenie [Comparative literature]. Leningrad, Nauka Publ., 1983. 448 p. (In Russ.) 
Belinskii V. G. Sobr. soch. v 3 t. T. 3 [Coll. Op. In 3 volumes. Vol. 3]. Moscow, Gos. izdat. khud. lit. Publ., 1948. 928 p. (In Russ.)

Beliaeva I. A. «Strannye sblizheniia»: Goncharov i Dante ["Strange convergence": the potters and Dante]. Izv. RAN. Ser. lit. i iazyka Publ. Moscow, 2007. Vol. 66, № 2. P. 23-28. (In Russ.)

Beliaeva I. A. «Troistvennaia poema» russkoi zhizni: Dante Alig'eri - S. P. Shevyrev I. A. Goncharov ["Triple poem" of Russian life: Dante Alighieri - S. P. Shevyrev I. A. Goncharov]. Slavianskii mir: obshchnost' i mnogoobrazie: Kolomna, Materialy mezhdunar. nauch.-prakt. konf. Kolomen. gos. ped. in-t Publ., 2007. Ch. 1. Literaturoved. P. 37-40. (In Russ.)

Bogomolova N. V. Evoliutsiia zhenskogo kharaktera $v$ trilogii I. A. Goncharova [Evolution of the female character in I. A. Goncharov's trilogy]. Russian literary studies at the present stage: Proceedings of the V International conference. Moscow, Moscow state Open pedagogical University named after M. A. Sholokhov Publ, 2006, Vol. 1. P. 90-94. (In Russ.)

Bogomolova N. V. Evoliutsiia avtorskogo mirovideniia v trilogii I. A. Goncharova [Evolution of the author's worldview in Goncharov's trilogy]. diss. kand. filol. nauk. Moscow, 2009. 212 p. (In Russ.)

Vorob'eva M. S. «Karnaval'nye pary» v romanakh I. A. Goncharova [“Carnival couples” in I. A. Goncharov's novels]. Vestnik Nizhegorodskogo unstituta im. N. I. Lobachevskogo. Ser. Filoligia. 2004, № 1(5). P. 28-32. (In Russ.)

I. A. Goncharov. Materialy i issledovaniia. Lit. nasl. [Materials and research. Literary heritage]. Vol. 102. Moscow, Nauka Publ, 2000. 736 p. (In Russ.)

Goncharov I. A. O pol'ze istorii [The benefits of history]. Nedelia. Moscow, 1965. № 32. (In Russ.)

Goncharov I. A. Pis'mo k V. S. Solov'evu [Letter to V. S. Solovyov]. Predislovie i publikatsiia V. I. Mel'nika. I. A. Goncharov . Ul'ianovsk. 1994. S. 343-351. (In Russ.)

Goncharov I. A. Poln. sobr. soch v 20 t. [Complete works in 20 vols]. Vol. 1-10. SaintPetersburg, Nauka Publ., 1997-2014. (In Russ.)

Goncharov I. A. Sobr. soch. v 8 t. [ Complete works in 8 vols.]. Moscow, Gos. Izd-vo khud. lit. Publ., 1952-1955. (In Russ.)

Goncharov I. A. Sobr. soch. v 8 t. [Complete works in 8 vols]. Moscow, Khud. lit., 1978-1980. (In Russ.)

Domanskii V. A. Sady Goncharova [Goncharovs Gardens] Domanskii V. A., Kafanova O. B., Sharafadina K. I. Literatura v sinteze iskusstv: V 3 t. SPb. gos. un-t tekhnol. i dizaina. Saint-Petersburg, 2010. Vol 1. Sad i gorod kak tekst. P. 187-223. (In Russ.)

Dostoevskii F. M. Sobranie sochinenii v 30 t. [Complete works in 3 vols]. Leningrad, Nauka Publ, 1972-1988. (In Russ.)

Kochetova V. G. K voprosu o tipologii kharakterov v proizvedeniiakh I. A. Goncharova [On the typology of characters in the works of I. A. Goncharov]. Khudozhestvennyi tekst: varianty interpretatsii, otv. red. V. A. Akimov. Biisk, 2006. Ch. 1. P. 281-288. (In Russ.)

Kubasov A. V. "Movizm» pozdnego Goncharova: "Mai mesiats v Peterburge» ["Momism" late Goncharov: "the month of May in St. Petersburg"]. Ul'ianovsk, 2017. P. 247-254. (In Russ.) 
Losev A. F. Vladimir Solov'ev [Vladimir Solovyov]. Moscow, 1983. 208 p. (In Russ.)

Liatskii E. A. Roman i zhizn': Razvitie tvorcheskoi lichnosti I. A. Goncharova: Zhizn' $i$ byt. 1812-1857 [Novel and life: the Development of the creative personality by I. A. Goncharov: the Life and way of life] Praga, Plamya, 1925. 392 p. (In Russ.)

Mel'nik V. I. Evangel'skii tekst novelly-pritchi «Ukha» I. A. Goncharova [The gospel text of the novel-parable "Ear" I. A. Goncharov]. Problemy istoricheskoi poetiki. Petrozavodsk. 2017. Vol. 15, № 2. P. 60-80. (In Russ.)

Mel'nik V. I. I. A. Goncharov: dukhovnye i literaturnye istoki [Goncharov: spiritual and literary sources.]. Moscow, Moscow state University of printing arts Publ., 2000. 282 p. (In Russ.)

Mel'nik V. I. Goncharov i pravoslavie: dukhovnyi mir pisatelia [Goncharov and Orthodoxy: the spiritual world of the writer]. Moscow, "Dar" Publ., 2008. 544 p. (In Russ.)

Mel'nik V. I. Realizm I. A. Goncharova [Realism of I. A. Goncharov]. Vladivostok, Izdvo Dal'nevostochnogo gosuniversiteta Publ., 1985. 140 p. (In Russ.)

Mel'nik V. I. Tema donzhuanizma v tvorchestve I. A. Goncharova [Theme longuenesse in the works of I. A. Goncharov]. Metod, zhanr, poetika v zarubezhnoi literature. Frunze, Izd-vo Kirgizskogo gosuniversiteta Publ., 1990. P. 49-59. (In Russ.)

Mel'nik V. I. Eticheskii ideal I. A. Goncharova [I. A. Goncharov's ethical ideal]. Kiev, «Lybid'» Publ., 1991. 152 p. (In Russ.)

Merzliakov A. Kratkoe nachertanie teorii iziashchnoi slovesnosti [Brief outline of the theory of fine literature]. Moscow, 1822. 328 p. (In Russ.)

Nedzvetskii V. Psikhologicheskoe techenie v literature kriticheskogo realizma (Turgenev, Goncharov, Pisemskii, Ostrovskii) [Psychological course in the literature of critical realism (Turgenev, Goncharov, Pisemsky, Ostrovsky)]. Razvitie kriticheskogo realizma v russkoi literature: v 3 t. / otv. red. K. N. Lomunov. Moscow, Nauka Publ., 1973. Vol. 2, Ch. 1. P. 15-149. (In Russ.)

Nikitina N. I., Sukailo V. A., Kukueva A. I. Opisanie biblioteki I. A. Goncharova. Katalog [Description of the library I. A. Goncharov. Catalogue]. Ul'ianovsk, 1987. 120 p. (In Russ.)

Otradin M. V. Proza I. A. Goncharova v literaturnom kontekste [Goncharov's prose in the literary context]. Saint-Petersburg, SPb university Publ., 1994. 168 p. (In Russ.)

Prutskov N. I. Masterstvo Goncharova-romanista [Skill Goncharov-novelist]. Moscow-Leningrad, AN SSSR Publ., 1962. 320 p. (In Russ.)

Retsov V. V. Ivan Aianov v roli «nesravnennogo Leporello ( $k$ voprosu o teme Don Zhuana v romane I. A. Goncharova «Obryv» [Ivan Ayanov in the role of incomparable Leporello (on the topic of don Juan in the novel by I. A. Goncharov "Break"]. Izvestiia Iuzhnogo federal'nogo universiteta. 2015, № 1. P. 38-46. (In Russ.)

Solov'ev V. S. Izbrannoe [Selected works]. Moscow, Sovetskaia Rossiia Publ., 1990. 496 p. (In Russ.)

Solov'ev V. S. Chteniia o bogochelovechestve [Reading about God-manhood]. Moscow, 1881. 382 p. (In Russ.)

Prof. Nikolai Stelletskii. Opyt nravstvennogo pravoslavnogo bogosloviia $v$ apologeticheskom osveshchenii [The experience of moral Orthodox theology in an apologetic light]. In 3 vols. Vol. 2. Moscow, FIV Publ., 2011. 736 p. (In Russ.) 
Tindal' D. Rechi i stat'I [Speeches and articles]. Moscow, 1875. 188 p. (In Russ.)

Tolstaia S. A. Dnevniki. In 2 vols. Vol. 1. Moscow, Khud. lit. Publ., 1978. 628 p. (In Russ.)

Turgenev I. S. Polnoe sobranie sochinenii i pisem $v 28 t$ [Complete works and letters. In 28 vols.] Vol. XII. Moscow- Leningrad, Nauka Publ., 1966. 584 p. (In Russ.)

Flammarion K. Mnogochislennost' obitaemykh mirov [The number of inhabited worlds]. Moscow, Tovarishchestvo I. D. Sytina Publ., 1908. 240 p. (In Russ.)

Flammarion K. Planeta Mars i usloviia obitaniia na nei [The planet Mars and the habitat on it]. Moscow, 1909. 234 p. (In Russ.)

Tseitlin A. G. Goncharov [Goncharov]. Moscow, Izd-vo AN SSSR Publ., 1950. 492 p. (In Russ.)

Tseitlin A. G. Trilogiia Goncharova [Goncharov's Trilogy]. Rodnoi iazyk v shkole. 1927. No 4. P. 95-108. (In Russ.)

Khuviler - Fan der Khagen A. Trilogiia li romany Goncharova? Ivan A. Goncarov: Leben, Werk und Wirkung. Beitrage der I. Internationalen Goncarov-Konferenz. Koln, 1994. S. 73-81.

Shevyrev S. P. Dant i ego vek. Issledovanie o Bozhestvennoi komedii [Dant and his age. The study of the divine Comedy]. Uchen. zap. Imperatorskogo Moskovskogo universiteta. Moscow, Universitetskaia tipografiia. 1834, № 7. P. 118-180. (In Russ.)

Shevyrev S. P. Izbrannye trudy [Selected works]. Moscow, Rossiiskaia politicheskaia entsiklopediia Publ., 2010. 776 p. (In Russ.)

Sheftsberi A. Esteticheskie opyty [Aesthetic experience]. Moscow, Iskusstvo, 1975. 536 p. (In Russ.)

Shiller F. Sobr. soch.: $v 7 t$. [Collected works in 7vols] Vol. 6. Moscow, Khudozhestvennaia literature Publ, 1955-1957. 792 p. (In Russ.)

Charles H. Kahn. Anaximander and the Originsof Greek Cosmology. Columbia University Press, New York, 1960. Per. M. N. Vol'fa URL: https://nsu.ru/classics/Wolf/ Kahn_2.htm (access date: 04.07.2019).

Dreper J. History of the conflict between religion and science. New York: D. Appleton, 1874. $266 \mathrm{p}$.

Dreper J. History of the intellectual development of Europe. Paris, 1862. 554 p.

Figuier L. L' annee scientifiqe et industrielle. Paris, 1875.855 p.

Flammarion C. La pluralite des mondes habites, etudes ou 1 on expose les conditions... Paris, $1872.366 \mathrm{p}$.

Flammarion C. Les merveilles celestas, lectures du Soir. Paris, 1869. 362 p.

Flammarion C. Recits de 1 infini, humaine histoire d une cjmete dans 1 infini. Paris, 1873. $416 \mathrm{p}$.

Secchi A. Le Soleil: expose des principales decouvertes modernes sur la structure de cet, son influence dans l'univers et ses relations avec les autres corps celestas... Paris, $1870.432 \mathrm{p}$. 


\section{Петербург, Москва, провинция в творчестве А. Н. Островского и И. А. Гончарова}

Аннотация: В статье освещается проблематичный для исследователей вопрос о возможности сближения творчества драматурга Островского и прозаика Гончарова. Автор считает, что такое сближение возможно на разных уровнях: мировоззренческом и художественном. Особое внимание в статье уделяется образам Петербурга и Москвы у Островского и Гончарова, их пониманию русской провинции. Впервые предпринятое сравнение изображения столицы и провинции этими художниками позволяет показать своеобразие картины мира в творчестве каждого из них. Актуальность работы определяется привлечением новых для исследователей данной темы в творчестве Гончарова источников - «Фрегата “Паллада"» и поздних очерков. В результате анализа автор приходит к выводу о том, что при очевидном различии общественных позиций художников, разном их отношении к дворянству, его роли в общественной жизни России в 1860-70-х гг., в их творчестве появляются произведения, в которых представители московского и петербургского света получают близкие нравственные характеристики, изображаются с использованием одних и тех же поэтических приёмов. Имея в виду такое сходство, автор допускает возможность влияния Гончарова на Островского. Однако в том, как изображена Гончаровым русская провинция в романе «Обрыв», в перенесении акцента в этом романе на изображение женщины, величия её души, её грехопадения, в стремлении увязать судьбу героини с судьбой Отечества, в использовании для характеристики героини образа птицы, автору статьи видится влияние Островского на Гончарова.

Ключевъе слова: Гончаров, Островский, Петербург, Москва, столица, провинция, приёмы создания образа, женские образы

Информация об авторе: Ермолаева Нина Леонидовна, ORCID 0000-0001-67593590 , доктор филологических наук, доцент, г. Иваново, Россия

E-mail: ninaermolaeva1@yandex.ru

Дата поступления статьи в редакиию: 08.08 .2008

Дата публикации статьи: 10.12.2019

Для цитирования: Ермолаева Н. Л. Петербург, Москва, провинция в творчестве А. Н. Островского и И. А. Гончарова // Два века русской классики. 2019. Т. 1. № 2. C. 144-173. DOI 10.22455/2686-7494-2019-1-2-144-173 




This is an open access article distributed under the Creative

Commons Attribution 4.0

International (CC BY 4.0)

(c) 2019. Nina L. Ermolaeva

Ivanovo, Russia

\title{
Saint-Petersburg, Moscow, Province in the creative work of I. A. Goncharov and A. N. Ostrovsky
}

\begin{abstract}
The article covers the problematic for the researchers issue - the possibility of comparing the creative work of the playwright Ostrovsky and the prosaic Goncharov. The author considers such comparing approach to be possible at both ideological and artistic levels. Special attention is paid to the images of Saint-Petersburg and Moscow in the works by Ostrovsky and Goncharov, and their understanding of the Russian province. The newly made comparison of the depiction of capital and province by these artists allows us to show the specificity of the image of the world in the creative work of each of them. The actuality of the work is in the use of the new for the research of the theme sources by Goncharov: "Frigate "Pallada"' and the late essays. As the result of the analysis the author comes to the conclusion that with the obvious difference in the social position of the writers, variety in the attitude towards nobility and its role in the social life of Russia of 1860-70s, their creative heredity has the works where the people from Moscow and Saint-Petersburg society get close moral characteristics and are characterized and portrayed with the use of the same poetic techniques. Keeping in mind this commonality, the author states the possibility of Goncharov's influence on Ostrovsky. Besides, the depiction of the Russian province by Goncharov in "Obryv (Precipice)" and his shift of accent to the portrait of a woman and the greatness of her soul, her fall, the pursuit to connect her destiny with the one of the Motherland as well as the use of the image of a bird as her characteristics allows the author of the article to see the influence of Ostrovsky on Goncharov.
\end{abstract}

Keywords: Saint-Petersburg, Moscow, capital and province, devices of creating the image, female images, the image of a bird

Information about the author: Nina L. Ermolaeva, DSc in Philology, associate professor, Ivanovo, Russia.

E-mail: ninaermolaeva1@yandex.ru

Received: September 08, 2019

Published: December 10, 2019

For citation: Ermolaeva N. L. Saint-Petersburg, Moscow, Province in the creative work of I. A. Goncharov and A. N. Ostrovsky. Two centuries of the Russian classics, 2019, vol. 1, № 2, pp. 144-173. (In Russ.) DOI 10.22455/2686-7494-2019-1-2-144-173 
Вопрос о творческих связях драматурга Островского и прозаика Гончарова можно считать лишь заявленным в нашем литературоведении. Причиной столь малого внимания к этой проблеме являются в определённом смысле «взаимоисключающие» отношения между жанрами, органичными для дарования каждого из писателей: справедливо убеждение, что как драме противопоказано повествовательное начало, так и эпосу вредна излишняя драматизация.

И всё-таки исследователи, обращавшиеся к этой проблеме: А. И. Журавлёва [Журавлёва, 1988: 113-169], М. В. Отрадин ${ }^{1}$, В. Н. Криволапов [Криволапов: 80-91], единодушны в понимании общего основания для сближения творчества художников: это их эпическое дарование, выразившееся как начало повествовательное и как интерес и симпатии к эпическому, патриархальному укладу.

Сближает творчество художников и обращение к целому ряду общих тем, одна из которых - столица и провинция. Среди русских писателей XIX в. немного найдётся таких, которые были бы более привержены одному городу, как Островский - Москве, а Гончаров Петербургу; без творчества Островского невозможно представить того, что называют «московский текст», а без прозы Гончарова — того, что называют «петербургский текст»².

1 На Щелыковских чтениях 2004 г. М. В. Отрадин выступил с докладом «Гончаров и Островский».

2 О малой изученности «петербургского текста» в произведениях Гончарова говорил ещё В. Н. Топоров в своей методологически значимой работе «Петербург и Петербургский текст русской литературы” [Топоров: 259-367]. В значительно более поздней статье В. А. Доманского вновь находим сожаление по этому поводу [Доманский: 49]. Тема эта действительно оказалась малопривлекательна для исследователей. Е. С. Роговер, например, в своей монографии, посвящённой «петербургскому тексту» [Роговер], творчество Гончарова фактически обошёл вниманием. Мало интересует эта тема и авторов работ о «петербургском тексте» в русской 
Присутствуют ли приметы «петербургского текста» у Гончарова и «московского текста» у Островского? Противопоставлены ли в творчестве писателей Петербург и Москва? Каково понимание писателями традиционной оппозиции «столица и провинция»? Есть ли общее в понимании и изображении столицы и провинции в творчестве столь разных писателей, возможно ли было влияние одного на другого? Ответы на эти вопросы не могут быть однозначны.

Образ Петербурга у Гончарова во многом зависит от его восприятия героями: Петербург - это родное, безопасное, уютное, комфортное и удобное для личных и деловых отношений пространство героя Тяжеленко и рассказчика из «Лихой болести». В этом городе Егор Адуев из «Счастливой ошибки» осуществился как личность, нашёл своё счастье, мир равных ему по материальному и культурному уровню людей. Пожалуй, так же осмысливают Петербург и Петр Адуев, Поспелов из «Обыкновенной истории», Штольц и Ольга из «Обломова». Уже в этом романе рядом с истинными петербуржцами - франтом Волковым, чиновником Судьбинским, журналистом Пенкиным, «пролетарием» Тарантьевым, обывателем Алексеевым - является неотделимый от образа Петербурга чиновник-крючкотвор и взяточник Мухояров. Ментально не связаны с Петербургом лишь слуги Евсей и Захар, мечтающие о земном рае - деревенской идиллии.

«Фрегат “Паллада”» — это произведение, в котором Петербург дан в изображении и оценке автора. В начале книги в одном из писем к друзьям он просит: «Пожалуйста, не пишите мне, что началась опера, что на сцене появилась новая французская пьеса, что открылось такое-то общественное увеселительное место: мне хочется забыть физиономию петербургского общества» [Гончаров, 1997. Т. 2: 38]. Автор воспринимает Петербург с его увеселениями как нечто «однообразное» и вольно или невольно встаёт в ряд с литературными героями, скучавшими в блестящем петербургском свете.

литературе. Москве в жизни и творчестве Островского посвящена обстоятельная монография А. И. Ревякина [Ревякин], на ту же тему есть интересные суждения в более новых работах В. В. Ожимковой [Ожимкова: 232-240] и Г. В. Мосалёвой [Мосалёва: 108-113], но исследователи «московского текста» о творчестве Островского, как правило, умалчивают [См.: Люсый, а также посвящённые «московскому тексту» многочисленные сборники статей Москва и «московский текст», 1998; 2004; 2007; 2010; 2012; 2013; 2015]. 
Очень скоро в чужих краях путешественник Гончарова в чём-то уподобится его же Александру Адуеву, соскучившемуся по Петербургу в деревне, - его одолеет ностальгия, и Петербург он будет вспоминать как родной и любимый город. Даже природа Петербурга, его переменчивая погода в представлении героя обретёт свои преимущества перед надоедливо однообразной роскошной природой южных широт: «А ведь как хорошо, красиво это безукоризненно чистое и голубое небо, синяя, беспредельная гладь моря, влажно-тёплый береговой воздух! Но и морская поэзия надоест, и тропическое небо, яркие звезды: помянешь и майские петербургские ночи, когда, к полуночи, небо захочет будто бы стемнеть, да вдруг опять засветлеет, точно ребенок нахмурится: того и гляди заплачет, а он вдруг засмеялся и пошёл опять играть!..» [Гончаров. 1997. Т. 2: 523].

Для путешественника из «Фрегата», как и для большинства героев ранних повестей, двух первых романов, в условиях тяжёлого быта на морском судне окажутся привлекательны удобства и комфорт, который предоставляет Петербург человеку: «Мы то лежим в дрейфе, то лениво ползём узел, два вперёд, потом назад, ходим ощупью: тьма ужасная; дождь, как в Петербурге, уныло и беспрерывно льёт, стуча в кровлю моей каюты, то есть в ют. Но в Петербурге есть ярко освещённые залы, музыка, театр, клубы - о дожде забудешь...» [Гончаров, 1997. Т. 2: 399]. На протяжении всего путешествия рассказчик будет уравнивать Петербург с любой из мировых столиц. Оказавшись в британском музее, он скажет: «Мы целое утро осматривали ниневийские древности, этрусские, египетские и другие залы, потом змей, рыб, насекомых - почти всё то, что есть и в Петербурге, в Вене, в Мадрите» [Гончаров, 1997. Т. 2: 41].

Образ Петербурга в произведениях Гончарова несёт на себе мистический отпечаток и в этом смысле близок «петербургскому тексту» Ф. М. Достоевского. Г. Гачев, говоря о «космосе» Достоевского, так определяет в нём значение образа Петербурга: «Камень - кесарево начало. Это прежде всего сам город Петербург, его дома, стены, заставы, дворы, его ритм и климат. Это служба, “должность”... Это порядок, социум. Запад, рассудок, логика» [Гачев: 231]. Уже в первом романе Гончарова Петербург - это город камня, «великолепная» каменная «гробница» [Гончаров, 1995. Т. 1: 425]. Потаённый смысл образа камня в «Обыкновенной истории» позволяет рассмотреть сюжет романа как 
рассказ о постепенном охлаждении и превращении в камень горячего, трепетного сердца Александра Адуева. Для Петербурга - это обыкновенная история, история, подобная той, что случается почти с каждым его жителем. Тема душевного окаменения человека в романе связана и с Петром Адуевым, имя которого «камень», и с другом Александра Поспеловым, и Лизаветой Александровной [См.: Ермолаева, 2000].

В романе «Обломов» тема камня как бы уходит на второй план, уступая место теме сна жизни. Однако для этого произведения актуален миф о Пигмалионе и Галатее, он имеет двойной смысл: «окаменевшего» сонного Обломова тщетно пытается поднять с дивана, «оживить» Ольга; Обломов же своим «золотым сердцем» сумел пробудить самосознание «каменной бабы» вдовы Пшеницыной: «Она поняла, что проиграла и просияла ее жизнь ... теперь уж она знала, зачем она жила и что жила не напрасно» [Гончаров, 1998. Т. 4: 488].

$\mathrm{B}$ «Обрыве» характеристике Петербурга будет уделено значительно меньше места, чем в первых романах. В «Обрыве» обитатели города окажутся увидены не только автором, но и героем, Райским, значительная часть жизни которого прошла в нём. Хотя прогулка по Невскому проспекту доставляет герою удовольствие, однако в Петербурге он ощущает однообразие и скуку, видит отпечаток «окаменелости», «сна жизни» в Аянове и Софье Беловодовой, её тётушках Пахотиных. От этого однообразия Райский бежит в провинцию, но сон и скука и там настигнут его. То же однообразие будет тяготить Райского и в Италии. Образ сна жизни, скуки приобретёт у Гончарова всеохватывающее значение, писатель убеждён: они неизбежны и повсеместны. С ними необходимо смириться и в них осуществиться творческой личности. Об этом Гончаров скажет ещё в «Обломове». В финальных главах романа Ольга услышала из уст Штольца призыв смириться с таким однообразием и нашла в себе силы признать правоту мужа [См.: Ермолаева, 2009: 29]. В этом смысле провинция и Петербург в творчестве Гончарова не противопоставляются. В Петербурге, как и в Европе, в русской деревне, есть место творческой личности. Покой и порядок необходимы для вдохновения. Это понимает Райский, роман которого значительно продвинулся в Малиновке, там же его одолело желание стать скульптором, и не Малиновка, не Петербург и не Италия виноваты в том, что ему не преодолеть свой дилетантизм. В своём последнем романе Гончаров не в Петербурге, а в провинции увидит движение жизни. 
Он свяжет свои представления не только с образом предприимчивого труженика Тушина, но прежде всего с образами русских женщин Веры и бабушки.

В позднем творчестве Гончарова образ Петербурга заметно изменяется. Очерк «Литературный вечер» изображает представителей высшего света и творческую интеллигенцию города. На светских людях, как и на героях романов, лежит печать «окаменелости». Это княжна Тецкая, лицо которой похоже на мраморное изваяние, «светская окаменелость» Пестов, графиня, которую за её умные глаза и загадочную улыбку прозвали «сфинксом», [Гончаров, 1952. Т. 7: 109-111]. Уранов своей привычкой к Петербургу, нежеланием покидать город даже летом, одиночеством, образом жизни, сферой общения очень напоминает типичного петербуржца Аянова. Среди героев очерка помещён и сонный, ко всему равнодушный, апатичный «пожилой беллетрист» Скудельников, в образе которого, по мнению исследователей, Гончаров изобразил самого себя.

В ранних повестях и романах Гончарова Петербург почти исключительно дворянский город. В повестях «Лихая болесть», «Счастливая ошибка», в «Папиньерке», «Письмах столичного друга к провинциальному жениху», «Иване Савиче Поджабрине», в романах появляются лишь отдельные персонажи из народного мира, это, как правило, герои, обслуживающие представителей дворянства. В поздних же очерках - «Литературный вечер», «Слуги старого века», «Май месяц в Петербурге», «Превратность судьбы» - появляются новые лица. В очерке «Литературный вечер» - известный артист, исполнивший роль журналиста Крякова, в «Слугах старого века» - писатель, автор «Обломова», в очерке «Превратность судьбы» - обедневший дворянин, честный труженик Хабаров, а рядом с ними - многочисленные представители мещанства, чиновничества, разного рода прислуга. Всё это даёт основания утверждать, что в поздних очерках образ Петербурга у Гончарова демократизируется.

Очевидной натяжкой представляется нам суждение Е. А. Краснощёковой о героях «Обыкновенной истории»: «Суть гончаровских характеров была прямо связана с московско-петербургским контрастом. Действительно, юный Александр подходит под определение «москвич»: он тяготится службой, приветлив, откровенен, наивен...» [Краснощёкова: 66]. Однако оппозиция «Москва - Петербург» в произведениях Гонча- 
рова 1840-х годов не отражена. В романе «Обыкновенная история» Москва никак не противопоставлена Петербургу, разве что в словах Евсея о том, что в Петербург «иной раз из Москвы солёные-то огурцы возят» [Гончаров, 1995. Т. 1: 438]. Гончаров противопоставляет Петербург не Москве, а провинции. Достоверным источником для понимания гончаровской позиции может служить книга очерков «Фрегат “Паллада”». В ней Москва не раз оказывается в одном ряду с Петербургом и другими столицами мира: «Некоторые постоянно живут в Индии и приезжают видеться с родными в Лондон, как у нас из Тамбова в Москву» [Гончаров, 1997. Т. 2: 19]; «Переход от качки и холода к покою и теплу был так ощутителен, что я с радости не читал и не писал, позволял себе только мечтать - о чем? о Петербурге, о Москве...» [Гончаров, 1997. Т. 2: 103]; «Некоторые из негров бранились между собой - и это вы знаете: попробуйте остановиться в Москве или Петербурге, где продают сайки и калачи, и поторгуйте у одного: как всё это закричит и завоюет! То же и здесь, да и везде, как кажется» [Гончаров, 1997. Т. 2: 112]; «Это и есть знаменитое кальсадо, или гулянье, о котором говорил мсье Demien. Проехав раза два по нём взад и вперед, я отправился в отель. Кальсадо не уйдет; да хоть бы и ушло - не беда: это та же Москва, Петербург, Берлин, Париж и т. д.» [Гончаров, 1997. Т. 2: 541].

Следует заметить, однако, что Москва в творчестве Гончарова иногда и уравнивается с провинцией. Во «Фрегате...» читаем: «Знаете ли, чем поражен был мой первый взгляд? какое было первое впечатление? Мне показалось, что я вдруг очутился на каком-нибудь нашем московском толкучем рынке или на ярмарке губернского города, вдалеке от Петербурга, где еще не завелись ни широкие улицы, ни магазины; где в одном месте и торгуют, и готовят кушанье, где продают шёлковый товар в лавочке, между кипящим огромным самоваром и кучей кренделей, где рядом помещаются лавка с фруктами и лавка с лаптями или хомутами. Разница в подробностях...» [Гончаров, 1997. Т. 2: 416].

В представлении героев романов Гончарова Москва тоже разная. Для обломовцев Москва - это такой же далёкий край, столица, как и Петербург: «Они знали, что в восьмидесяти верстах от них была “губерния”, то есть губернский город, но редкие езжали туда; потом знали, что подальше, там, Саратов или Нижний; слыхали, что есть Москва и Питер...» [Гончаров, 1998. Т. 4: 103]. Татьяна Марковна Бережкова ни за что не соглашалась на предложение Марьи Егоровны отпустить 
Викентьева и Марфиньку в Москву, в Петербург и даже за границу. «Испортить хотите их», - говорила она. Москва, Петербург и заграница для бабушки - обитель «всякого нового распутства» [Гончаров, 2004. Т. 7: 499]. Но в то же время Москва - это город, в котором можно получить прекрасное образование: главные герои всех трёх романов писателя - Александр Адуев, Обломов, Штольц, Райский, как и путешественник во «Фрегате», - учились в Московском университете. По мысли И. А. Беляевой, Москва «и искушает, и развивает» героев Гончарова [Беляева: 8]. Бабушка Бережкова хочет посватать внуку дочь богатого откупщика Мамыкина, обучавшуюся в Москве, и это обстоятельство - гарантия равенства уровня культуры предполагаемых жениха и невесты. Даже для Райского Москва равна столицам мира. Завлекая Марфиньку в мир, отличный от Малиновки, он говорит: «Ты слыхала про Москву, про Петербург, про Париж, Лондон: разве тебе не хотелось бы побывать везде?» [Гончаров, 2004. Т. 7: 215]. Московский университет приобщил Райского к русской истории, красоте, учёности. Представления художника Райского о Москве связаны с её стариной, с истоками русской нации. Москва казалась ему «необъятным ветхим царством. Драки, казни, татары, Донские, Иоанны - всё приступало к нему, всё звало к себе в гости, смотреть на их жизнь» [Гончаров, 2004. Т. 7: 41]. Из Москвы в Малиновку и в губернский город везут наряды и моды, экипажи. Всё это позволяет усомниться в справедливости мнения Краснощёковой о том, что образ Москвы в творчестве писателя «воссоздан в описании провинциальных городков и мелкопоместных имений» [Краснощёкова: 485].

Если в творчестве Гончарова московская топонимика практически не отражена, Москва в его произведениях представлена и как одна из столиц мира, но и как столица, непосредственно близкая русской провинции, в определённом смысле рубеж между провинцией и Петербургом, то в пьесах Островского Москва имеет множество топонимических характеристик. В. В. Ожимкова пишет о том, что «московские адреса мелькают у Островского десятками...» [Ожимкова: 234]: Гостиный двор, Таганка, Ильинка и др. Но заметим, что чаще других упоминается «яма» у Воскресенских ворот, находившаяся вблизи Красной площади. В яму опускают разного рода должников: Большова («Свои люди, сочтёмся»), Лавра Мироныча Прибыткова («Последняя жертва»), Константина Каркунова («Сердце не камень»), яма грозит и Те- 
лятеву («Бешеные деньги»), Дульчину («Последняя жертва»), Николаю Шаблову («Поздняя любовь»), Платону Зыбкину («Правда хорошо, а счастье лучше»).

Москва в изображении Островского - это город, населённый трудящимся людом. Местом обитания героев «московских» пьес драматурга становится Замоскворечье, а то и окраина Москвы: это пьесы «Не было ни гроша, да вдруг алтын», «Последняя жертва», «Поздняя любовь», трилогия о Бальзаминове, «Сердце не камень» и др. Драматург точно отразил представление России о Москве, высказанное русским философом и мыслителем Г. П. Федотовым: «За что Россия так любила Москву? За то, что узнавала в ней себя. Приезжий мещанин из Рыбинска, из Чухломы мог найти здесь привычный уют... одноэтажные домики, дворы, заросшие травой, где можно летом дуть самовар за самоваром...» [Федотов: 56]. Для Островского не существует границы между «русской» столицей Москвой и провинцией. Он убеждён: люди везде одинаковы. И несомненно права А. И. Журавлёва в том, что драматург «завершает разрушение идеологической оппозиции “столица — провинция”, начатое Пушкиным» [Журавлёва, 1981: 46].

Москва, по Островскому, это и город, о котором писал М. Н. Загоскин: «Я изучал Москву с лишком тридцать лет и могу сказать решительно, что она не город, не столица, а целый мир - разумеется, русский. В ней сосредоточивается вся внутренняя торговля России; в ней процветает наша ремесленная промышленность. Как тысячи солнечных лучей соединяются в одну точку, проходя сквозь зажигательное стекло, так точно в Москве сливаются в один национальный облик все отдельные черты нашей русской народной физиономии. Европейское просвещение Петербурга; не вовсе чуждое тщеславия хлебосольство наших великороссийских дворян; простодушное гостеприимство добрых сибиряков; ловкость и досужество удалых ярославцев, костромитян и володимирцев; способность к письменным делам и необычайное уменье скрывать под простою и тяжелою наружностью ум самый сметливый и хитрый - наших, некогда воинственных, малороссиян; неуклюжество и тупость белорусцев; страсть к псовой охоте степных помещиков; щегольство богатых купцов отличными рысаками; безусловное обожание всего чужеземного наших русских европейцев и в то же время готовность их умереть за славу и честь своей родины; безотчетная ненависть ко всему заморскому 
наших запоздалых староверов, которые, несмотря на это, не могут прожить без немецкой мадамы или французского мусью; ученость и невежество, безвкусие и утонченная роскошь; одним словом, вы найдете в Москве сокращенье всех элементов, составляющих житейский и гражданский быт России, этого огромного колосса, которому Петербург служит головою, а Москва сердцем. Москва - богатый, неисчерпаемый рудник для каждого наблюдателя отечественных нравов» [Загоскин: 9]. Как и Загоскин, Федотов, Островский указал на кровную, нерасторжимую связь Москвы с Россией: «Москва уж теперь не ограничивается Камер-коллежским валом, за ним идут непрерывной цепью, от Московских застав вплоть до Волги, промышленные фабричные сёла, посады, города и составляют продолжение Москвы. Две железные дороги от Москвы, одна на Нижний-Новгород, другая на Ярославль, охватывают самую бойкую, самую промышленную местность Великороссии <...> Кроме того, Москва - патриотический центр государства, она недаром зовётся центром России. Там древняя святыня, там исторические памятники, там короновались русские цари и коронуются русские императоры, там, ввиду торговых рядов, на высоком пьедестале, как образец русского патриотизма, стоит великий русский купец Минин. В Москве всякий приезжий, помолясь в Кремле русской святыне и посмотрев исторические достопримечательности, невольно проникается русским духом. В Москве всё русское становится понятнее и дороже. <..> Москва - город вечно обновляющийся, вечно юный; через Москву волнами вливается в Россию великорусская народная сила. Эта великорусская народная сила, которая через Москву создала государство российское. Всё, что сильно в Великороссии умом, характером, всё, что сбросило лапти и зипун, всё это стремится в Москву...» [Островский, 1960. Т. 10: 179180]. Такое представление Островского о Москве близко и понятно Гончарову. Возражая хулителям драматурга, в неоконченной статье о нём писатель скажет: «Не “исписался" Островский, а исписал всю московскую жизнь, не города Москвы, а жизнь московского, то есть великорусского государства...» [Гончаров, 1952. Т. 7: 215].

Однако Москва у Островского - это и богатый, равнодушный к человеку город, город социальных контрастов, город невежественных купцов-самодуров, нечестных торгашей и разного рода махинаторов (Пузатов и Ширялов в «Семейной картине», Большов и Подхалюзин 
в «Своих людях» и др.), чиновников-взяточников (Беневоленский в «Бедной невесте», Вышневский, Юсов, Белогубов в «Доходном месте», Крутицкий в «Не было ни гроша, да вдруг алтын», прожигателей жизни и игроков, искателей богатых невест, подобных Вихореву («Не в свои сани не садись») или Дульчину («Последняя жертва»). Москва разоряет и опускает на самое дно, разуверяет в дружбе и порядочности Любима Торцова («Бедность не порок»). В Москве есть свои кумиры, которым поклоняются московские мещанки, купчихи, барыни, - блаженный Иван Яковлевич и монахиня Манефа (трилогия о Бальзаминове, «На всякого мудреца довольно простоты»). В Москве обитают «мелкий бес» Ерёмка («Не так живи, как хочется») и носитель страшной мистической силы денег Неизвестный («Пучина») [См.: Капустин]. В произведениях драматурга 1860-х-1880-х гг. Москва - город деловых людей, в котором красота становится предметом купли-продажи («Бешеные деньги», «Богатые невесты», «Красавец мужчина»), ради денег отвергаются всякие родственные связи и нравственные устои («Не от мира сего»). Москва - это «пучина», она губит, доводит до умственного помрачения Кирилла Кисельникова («Пучина»), до самоубийства Копрова («Трудовой хлеб») и Крутицкого («Не было ни гроша, да вдруг алтын»)...

Москва у Островского - русская столица, столица в понимании купечества и всего трудящегося люда России. Петербург появляется преимущественно в так называемых «дворянских» пьесах драматурга. Заметим при этом, что, как у Гончарова не отражена московская топонимика, так и у Островского мало отражена топонимика Петербурга. Для драматурга это город карьеры, больших денег, равный Парижу по возможностям «весёлой» жизни, какой живут там Леонид («Воспитанница»), Бабаев («Грех да беда на кого не живёт»). О такой жизни Глафира рассказывает Купавиной: «Нас окружали только люди богатые: адвокаты, банкиры, акционеры. Мы с сестрой жили в каком-то чаду: катанье по Невскому, в бархате, в соболях, роскошные обеды дома или в ресторанах; всегда в обществе: опера, французский театр, а чаще всего Буфф, пикники, маскарады...» («Волки и овцы») [Островский, 1960. Т. 7: 163]. Простой человек и Петербург в пьесах Островского несовместимы. О Петербурге говорят, из Петербурга приезжают и в него отправляются только люди богатые или мечтающие о карьере и больших деньгах: Беркутов («Волки и овцы»), Погуляев («Пучина»), Муров (Та- 
ланты и поклонники») ${ }^{1}$. В Петербурге находит для себя круг общения миллионщик Кнуров («Бесприданница»), Крутицкий советует Глумову («На всякого мудреца довольно простоты») отправиться в Петербург, поскольку «там служить виднее» [Островский, 1960. Т. 5: 310], да и сам Глумов знает, что карьеру делают не в Москве, а в Петербурге. Для Василькова («Бешеные деньги») в будущем Петербург откроет новые жизненные перспективы. В той или иной мере привязанность героев Островского к Петербургу становится в его пьесах способом почти отрицательной характеристики европеизированной столицы, а в «дворянских» пьесах служит усилению их антидворянского пафоса.

Гончаров и Островский точно отражают некоторые особенности семейного и бытового уклада жизни двух столиц. Петербургское чиновничество значительно отличается от московского. Главные герои всех трёх романов Гончарова: Александр Адуев, Обломов и Райский не нашли в своих столоначальниках того, что искали, - отеческой заботы и снисходительности, - а вот Юсов у Островского - семейный человек, он неустанно печётся о собственном потомстве, заботится о своих подчинённых, отечески их опекает и обучает «кодексу чести» взяточника: «Ты возьми, так за дело, а не за мошенничество» [Островский, 1959. Т. 2: 81]. Для молодых чиновников, готовых принять его правила жизни, Юсов - отец родной, с ними он готов разделить трапезу, на свадьбе явиться посажённым отцом, по их просьбе в трактире пуститься в пляс. Лесть и угодничество для него - норма служебных отношений.

Значительно различаются отношения между родителями и детьми в Петербурге и Москве. Типична для холодного петербургского света история воспитания Софьи Беловодовой. Мать в её детскую «не ходила», воспитание девочки было поручено немке и англичанке. По словам Софьи, когда её приводили «к maman», она, «прежде нежели поздоровается, пристально поглядит мне в лицо, обернет меня раза три, посмотрит, всё ли хорошо, даже ноги посмотрит, потом глядит, как я делаю кникс, и тогда поцелует в лоб и отпустит» [Гончаров, 2004. Т. 7: 95]. Софья не знала материнской любви и ласки, будучи уже взрослой, она не видит тёплого к себе отношения и со стороны тётушек. По словам Райского, они «рехнулись на приличии» [Гончаров, 2004. Т. 7: 100]. Мать Наденьки Любецкой почти не обеспокоена замужеством собственной

1 Те же характеристики Петербурга можно найти и в пьесах, написанных Островским в соавторстве с Н. Я. Соловьёвым и П. М. Невежиным. 
дочери, так же себя ведут и тётки Ольги Ильинской и Софьи Беловодовой. Возможно, причина этого в том, что в Петербурге, городе с преобладающим мужским населением, девушки-дворянки и с небольшим приданым не оставались одинокими.

Иначе живёт женская половина населения Москвы в пьесах Островского. Замужество девушки - главная забота московской маменьки: богатых купчих Пузатовой и Большовой, бедных чиновниц Незабудкиной, Кукушкиной, разорившейся дворянки Чебоксаровой, и даже богатой тётушки Турусиной. В Москве, этой всероссийской ярмарке невест, обеспеченных, порядочных молодых людей на всех не хватает. Именно здесь находят себе богатых невест такие охотники за состоянием, как Чубуков и Поль Прежнев, или «голь, ну голь, как есть во всей форме» [Островский, 1959. Т. 2: 340] - Миша Бальзаминов. Богатые московские невесты оказываются падки на мужскую красоту: Серафима Толстогораздова («Не сошлись характерами»), вдова Белотелова («Последняя жертва») или Сусанна из пьесы «Красавец мужчина».

В изображении Островского Москва - это город, в котором бедные девушки вынуждены трудиться день и ночь ради куска хлеба, сами себя обеспечивать: Лизавета Ивановна («В чужом пиру похмелье»), Оленька («Старый друг лучше новых двух»), Евгения и Наташа («Трудовой хлеб») или идти на содержание к богатым людям. Такова судьба героини пьесы «Богатые невесты» Белесовой, та же участь грозит Лизе из «Пучины», Насте из пьесы «Не было ни гроша, да вдруг алтын».

Подводя итог размышлениям о том, как осмысливали и изображали Москву и Петербург два близких друг другу писателя, можно было бы сделать вывод: у них не так уж много общего. Однако не картина жизни города и не отношение к нему сближают Островского и Гончарова, но способ изображения человека в нём. Оба автора убеждены: Петербург и Москва имеют своих представителей, каких трудно встретить в каком-либо другом городе, и в позднем творчестве стремятся непосредственно увязать образ героя с образом города: у Гончарова появляется образ типичного петербуржца - Аянов и Пахотин («Обрыв»), у Островского - образ москвича - Телятев и Кучумов, Глумов («Бешеные деньги»), Лавр Мироныч Прибытков («Последняя жертва») ${ }^{1}$.

${ }^{1}$ В пьесе «Последняя жертва» один из героев в афише назван этим словом: Москвич. 
Настойчиво и последовательно Гончаров накладывает на характеристику Аянова приметы Петербурга. Он «родился, учился, вырос и дожил до старости в Петербурге, не выезжая далее Лахты и Ораниенбаума с одной, Токсова и Средней Рогатки с другой стороны. От этого в нём отражались, как солнце в капле, весь петербургский мир, вся петербургская практичность, нравы, тон, природа, служба - эта вторая петербургская природа, и более ничего» [Гончаров, 2004. Т. 7: 6]. У него лицо «отличалось спокойствием или, скорее, равнодушным ожиданием ко всему, что может около него происходить. <..> Умеренные движения, сдержанная речь и безукоризненный костюм - вот его наружный портрет» [Гончаров, 2004. Т. 7: 5-6]. Аянов, имея двенадцатилетнюю дочь, воспитывавшуюся на казенный счет в институте, живёт как человек одинокий, он занимает очень приличный пост с жалованием в пять тысяч в год чистыми деньгами, играет в карты «без ошибки», живёт с комфортом в своё удовольствие: «Это был представитель большинства уроженцев универсального Петербурга и вместе то, что называют светским человеком. Он принадлежал Петербургу и свету, и его трудно было бы представить себе где-нибудь в другом городе, кроме Петербурга, и в другой сфере, кроме света, то есть известного высшего слоя петербургского населения; хотя у него есть и служба, и свои дела, но его чаще всего встречаешь в большей части гостиных, утром - c визитами, на обедах, на вечерах: на последних всегда за картами. Он так себе: ни характер, ни бесхарактерность, ни знание, ни невежество, ни убеждение, ни скептицизм» [Гончаров, 2004. Т. 7: 6].

«Чудесный мир» общения молодого человека в Петербурге - это мир женщин «особой породы»: «Как пар и машины заменили живую силу рук, так там целая механика жизни и страстей заменила природную жизнь и страсти. Это мир - без привязанностей, без детей, без колыбелей, без братьев и сестер, без мужей и без жен, а только с мужчинами и женщинами» [Гончаров, 2004. Т. 7: 89]. Жизнь в петербургском свете в душе Райского чуть не погасила веру «в честь, честность, вообще в человека» [Гончаров, 2004. Т. 7: 88].

Подобные характеристики в романе «Обрыв» вполне могли повлиять на способы характеристики персонажей в пьесах Островского конца 1860-1880-х гг. Мы находим это влияние уже в пьесе «Бешеные деньги», задуманной летом 1869 г., сразу после выхода в свет романа «Обрыв». Мир «без привязанностей, без детей, без колыбелей, без 
братьев и сестер, без мужей и без жен, а только с мужчинами и женщинами» [Гончаров, 2004. Т. 7: 89] - это мир Глумова, Кучумова, Телятева и других персонажей. Телятев так говорит о себе: «Кто в продолжении двадцати лет не пропустил ни одного балета, тот в мужья не годится» [Островский, 1960. Т. 5: 442]; «По-моему, чем в женщине меньше нравственности, тем лучше» [Островский, 1960. Т. 5: 455]. В этом смысле Москва Островского в значительной степени близка Петербургу Гончарова.

Но если Петербург - город, любящий строгий счёт деньгам, то Москва-матушка всех прокормит, даже и таких, как «антик» Иннокентий («Сердце не камень»), кому «умирать бы с голоду в другом месте» [Островский, 1960. Т. 8: 116]. В Москве можно жить, пользуясь всеми удовольствиями светского общения таким людям, как Телятев, который не служит, одинок и не имеет намерения жениться. О себе он говорит, что у него долгу «тысяч до трёхсот» и «всё чужое: лошади, экипажи, квартира, платье» [Островский, 1960. Т. 5: 500]. Телятев - «добрый малый» и убеждён: «Я в Москве и без денег проживу» [Островский, 1960. Т. 5: 489]. Небогатый его кошелёк всегда открыт для приятелей, он даёт деньги «по доброте сердечной», «лучше сказать, по нашей общей распущенности; когда есть деньги, давай первому встречному, когда нет - занимай у первого встречного» [Островский, 1960. Т. 5: 489]. В Москве, в этой, по словам Глумова («На всякого мудреца довольно простоты»), «обширной говорильне» [Островский, 1960. Т. 5: 250], можно, не имея ни гроша за душой, взять большое приданое, чего почти добивается герой, благодаря умению «говорить» с Мамаевым и Мамаевой, Крутицким, Городулиным, Турусиной, и только по причине его «простоты» богатая невеста срывается с крючка. Но в пьесе «Бешеные деньги», благодаря тому же таланту героя, замысел Глумова осуществится.

В Петербурге Гончарова есть свой «шалун» - Николай Васильевич Пахотин, «очень красивый, сановитый старик, с мягкими, почтенными сединами»: «По виду его примешь за какого-нибудь Пальмерстона». После смерти жены Пахотин «вдруг спохватился, что... не успел пожить и пожуировать»: «Он стал вознаграждать себя за верность в супружестве сумасбродными связями, на которые быстро ушли все наличные деньги, брильянты жены, наконец, и большая часть приданого дочери. <...> Когда источники иссякли, он изредка, в год раз, 
иногда два, сделает дорогую шалость, купит брильянты какой-нибудь Armance, экипаж, сервиз, ездит к ней недели три, провожает в театр, делает ей ужины, сзывает молодежь, а потом опять смолкнет до следующих денег. <...> Особенно красив он был, когда с гордостью вёл под руку Софью Николаевну куда-нибудь на бал, на общественное гулянье. Не знавшие его почтительно сторонились, а знакомые, завидя шалуна, начинали уже улыбаться и потом фамильярно и шутливо трясти его за руку, звали устроить весёлый обед, рассказывали на ухо приятную историю...» [Гончаров, 2004. Т. 7: 14]. Очевидно, что этот образ перекликается с несколькими персонажами поздних пьес Островского. Лавр Мироныч Прибытков («Последняя жертва») - по виду «настоящий милорд-с!»: «Ему бы с графом Биконсфильдом разговаривать-с» [Островский, 1960. Т. 5: 369]. Лавр Мироныч - как и Пахотин, поклонник всего французского, за что получает от дядюшки прозвище «Монте Кристо»; как и Пахотин, он слывёт мастером по устройству изысканных обедов, он тоже с гордостью выставляет напоказ свою дочь Ирину Лавровну. Сближает героев Островского и Гончарова и то обстоятельство, что обеды эти они устраивают в основном на чужой счёт.

Но более других персонажей «шалун» Пахотин близок ещё одному герою Островского, который также приобрёл особого рода дополнение к собственному имени, - «князеньке» Кучумову («Бешеные деньги»). Сближают героев возраст, неизменное участие в карточной игре, претензии на принадлежность к высшему свету и изысканность манер, шаловливая манера светского общения, увлечение француженками и всем французским у Пахотина, итальянским - у Кучумова, мечты о поездке в Париж с предметом греховной любви, в преклонных годах претензии на возможность нравиться молодым женщинам, то обстоятельство, что, по словам Гончарова о Пахотине, «свет, опыт, вся жизнь его не дали ему никакого содержания», но «образовали ему какой-то очень приятный мелкий умок и не знающий его с первого раза даже положится на его совет, суждение, и потом уже, жестоко обманувшись, разглядит, что это за человек» [Гончаров, 2004. Т. 7: 15]. Так и Чебоксаровы жестоко обманываются в «шалуне» и «папашке» Кучумове [Островскиц̆, 1960. Т. 5: 466]. И Пахотин и Кучумов женились на женщинах «с деспотическим характером», угадавших слабость мужа и прибравших его «к рукам» [Гончаров, 2004. Т. 7: 16]. Оба героя к старости успели «нанести смертельный удар своему состоянию» [Гончаров, 
2004. Т. 7: 14] и жили в постоянной материальной зависимости от родственников. Можно предположить, что подобные совпадения в характеристиках персонажей могли навести Гончарова на мысль о плагиате в пьесе Островского, однако, в отличие от Тургенева, драматург был вне подозрений.

Своеобразно раскрывается обоими писателями и тема русской провинции. Об этом немало написано в исследованиях об их творчестве. Нас интересует только один аспект этой темы, который позволяет говорить об очевидной их близости: Гончарова и Островского объединяет тема судьбы русской женщины. Оба писателя помещают героинь с ярко обозначенными приметами национального характера не просто в русскую провинцию, но в национальное пространство: Катерина и Лариса у Островского, как и бабушка Бережкова, Марфинька и Вера у Гончарова, связаны с символом русского мира - с Волгой. Заметим, что среди великих современников Гончарова и Островского подобную связь можно обнаружить, пожалуй, только у героев поэзии Н. А. Некрасова.

«Русская река» Волга для обоих писателей - родное и любимое пространство. Родившийся на берегу великой русской реки Гончаров всегда с особой любовью относился к волжским просторам. В воспоминаниях «На родине» он признается: «...Меня нередко манили куда-то вдаль широкие разливы Волги со множеством плавающих, как лебеди, белых парусов. Я целые часы мечтательно, ещё ребёнком, вглядывался в эту широкую пелену вод» [Гончаров, 1952. Т. 7: 283]. В статье «Лучше поздно, чем никогда» Гончаров пишет: «Сады, Волга обрывы Поволжья, родной воздух, воспоминания детства - всё это залегло мне в голову...» [Гончаров, 1952. Т. 8: 141]. Его роман «Обрыв» стал своеобразной данью обитателям родных мест [См.: Белкин].

Москвич по рождению Островский был связан с Поволжьем: его род происходил из костромских краёв, отец писателя родился, провёл детство и юность в Костроме. Островский полюбил Волгу и волжан в молодом возрасте, когда впервые в апреле 1848 г. отправился в поездку в только что купленное отцом Щелыково. Широко известны его признания в дневнике: «С Переславля начинается Меря - земля, обильная горами и водами, и народ и рослый, и красивый, и умный, и откровенный, и обязательный, и вольный ум, и душа нараспашку. Это земляки мои возлюбленные, с которыми я, кажется, сойдусь хорошо. <...> И всё 
идёт крещендо - и города, и виды, и погода, и деревенские постройки, и девки. $<\ldots>$ Что за сёла, что за строения, точно едешь не по России, а по какой-нибудь обетованной земле!» [Островский, 1978. Т. 10: $353-$ 354]. «Апрельское путешествие Островского в Кострому и Щелыково явилось решающим событием в становлении драматурга. Первую любовь к русской природе и истории, к быту и нравам народа Верхнего Поволжья драматург пронёс через всю жизнь», - пишет Ю. В. Лебедев [Лебедев: 133].

Тема Волги возникает во многих пьесах Островского [См.: Цветкова]. Как и Гончарова, Островского завораживали открывающиеся с высокого берега волжские виды. Восторг перед красотой волжской природы писатели вложили в образы своих любимых героинь. Фраза Островского из его дневника: «Мы стоим на крутейшей горе, под ногами у нас Волга...» [Островский, 1978. Т. 10: 357], - может быть отнесена к любой из героинь - Катерине и Ларисе у Островского или Вере у Гончарова. Каждая из них, как птица, воспаряет над бескрайним волжским простором, устремляясь взором и душой туда, в заволжские дали... Катерина: «Знаешь, мне иногда кажется, что я птица. Когда стоишь на горе, так тебя и тянет лететь» [Островский, 1959. Т. 2: 235]. Первая реплика Ларисы: «Я сейчас всё за Волгу смотрела; как там хорошо на той стороне!» [Островский, 1960. Т. 8: 20]. Первое появление Веры в романе: «В комнате было живое существо. Глядя с напряженным любопытством вдаль, на берег Волги, боком к нему, стояла девушка лет двадцати двух, может быть трех, опершись рукой на окно» [Гончаров, 2004. T. 7: 286].

Всех героинь объединяет общий сюжет, изложенный Гончаровым в 1860 г. в рецензии для комиссии по присуждению Уваровской премии на «Грозу». О пьесе он пишет: «Прежде всего она поражает смелостью создания плана: увлечение нервной, страстной женщины и борьба с долгом, падение, раскаяние, и тяжкое искупление вины, - всё это исполнено живейшего драматического интереса и ведено с необычайным искусством и знанием сердца» [Гончаров, 1952. Т. 8: 206].

Героини Островского и Гончарова не случайно вписаны в русское национальное пространство. Оба писателя с образом русской женщины, наделённой незаурядными личностными чертами, с её судьбой связывают динамику русской истории. В романе Гончарова появятся образы бабушки Бережковой - «бабушки России» - и Веры - «молодой Рос- 
сии». О своей героине писатель скажет: «Пала не Вера, не личность, пала русская девушка, русская женщина, - жертвой в борьбе старой жизни с новою: она не хотела жить слепо, по указке старших. Она сама знала, что отжило в старой, и давно тосковала, искала свежей, осмысленной жизни, хотела сознательно найти и принять новую правду, удержав и всё прочное, коренное, лучшее в старой жизни. Она хотела не разрушения, а обновления. Но она “не знала”, где и как искать» [Гончаров, 1952. T. 8: 162]. Эти размышления Гончарова очевидно свидетельствуют о том, что существовавшее в его более раннем творчестве противопоставление столицы и провинции стирается, теперь не в столице, а в провинции видит писатель признаки прогресса в жизни России.

О связи героинь Островского с судьбой Отечества напишут исследователи. По их мнению, творчество Островского отражает духовную эволюцию русского общества, в предреформенный и пореформенный период стремительно отказывающегося от старого, во многом патриархального жизненного уклада, хранившего связь с церковью и народной культурой. Конфликт между приверженцами этой культуры и теми, кто стремится усвоить новые нормы и правила поведения, приобщиться к буржуазной, европеизированной, светской культуре, отражен уже в москвитянинских пьесах Островского. «Гроза» становится в творчестве драматурга переломным произведением именно потому, что в ней этот конфликт обретает трагический накал. Осмысленный в пьесах «Не в свои сани не садись», «Бедность не порок», «Не так живи, как хочется», да отчасти уже и в «Своих людях» как частный, внутрисемейный, конфликт этот вырастает до общероссийского, национально значимого в «Грозе». Ю. В. Лебедев пишет: «В русской трагедии Островского сталкиваются, порождая грозовой разряд, две противостоящие друг другу культуры, а противостояние между ними уходит в глубину русской истории» [Лебедев: 144]. Об историческом для России смысле конфликта «Грозы» писала и А. И. Журавлёва: «Здесь через любовно-бытовую коллизию был показан эпохальный перелом, происходящий в простонародном сознании» [Журавлёва, 1987: 259].

Создавая образы своих героинь, Островский и Гончаров стремились к широким обобщениям. История Катерины и Ларисы для Островского и Веры для Гончарова - это история многих русских женщин. Островский шёл не только от жизни, но от фольклора. Судьба Катерины типична для русской народной песни: это судьба девушки, 
отданной замуж за немилого «чуж-чуженина в чужедальнюю сторонушку, что не сахаром посыпана, не мёдом полита», образ её ассоциируется с фольклорным образом непокорной невестки. В образе Ларисы воплощена типичная история соблазнённой и покинутой, характерная для городского жестокого романса. Истоки образа Веры у Гончарова нужно искать, прежде всего, в социуме. В черновых фрагментах к «Обрыву», а позднее в статье «Намерения, задачи и идеи романа “Обрыв” читаем: «...Меня давно, с молоду, занимал один из важных, вопиющих, по своей несправедливости, вопрос: это вопрос о так называемом $n a-$ дении женщины. Меня всегда поражали: во-первых - грубость в понятии, которым определялось это падение, а во-вторых - несправедливость и жестокость, обрушиваемое на женщину за всякое падение, какими бы обстоятельствами оно ни сопровождалось, - тогда как о падении мужчин вовсе не существует никакого вопроса» [Гончаров, 1952. Т. 8: 131]. На перекличку этого мотива, существовавшего уже в ранней редакции «Обрыва», с произведениями современников указал ещё А. Г. Цейтлин: «Можно представить себе, как сильно звучали бы эти строки первоначального текста, если бы они были опубликованы вместе с текстом всего романа в 50-е годы: в те годы была бы вполне ясна их перекличка с аналогичными мотивами “Грозы” Островского, “Горькой судьбины” и первых прозаических произведений Писемского» [Цейтлин: 279].

Не будучи сторонниками современной идеи женской эмансипации, писатели обратились к нравственной стороне проблемы. Обоих интересует способ выхода героини из сложившейся после грехопадения ситуации. «Горячее сердце» одиноких в окружающем их мире героинь Островского «подсказывает» трагический выход - самоубийство. Окружённая любящими её людьми, Вера у Гончарова пойдёт разумным путём, указанным Богом и бабушкой: путём покаяния. И это для неё путь к самоуважению и уважению окружающих. Финал романа даёт надежду на возможную счастливую судьбу героини.

Сближает героинь Островского и Гончарова и то обстоятельство, что для их характеристики использован образ птицы. В символике и мифологии народов мира птицы обладают «преимущественно позитивным значением» [Бидерман: 215], образ птицы связывается с человеческой душой, птица ближе к небу, к ангелам. Птица в народном сознании это и символ свободы, воли: «...Благодаря своим крыльям близкие к небу 
существа часто служили олицетворением человеческого желания освободиться от земной тяжести и, подобно ангелам, подняться в высшие сферы. <...> Образы птиц часто представляют освобождённую от плоти человеческую душу...» [Бидерман: 215]. Мечтой о полёте, о возможности оторваться от земли живёт Катерина: «...Отчего люди не летают так, как птицы? Знаешь, мне иногда кажется, что я птица. Когда стоишь на горе, так тебя и тянет лететь. Вот так бы разбежалась, подняла руки и полетела» [Островский, 1959. Т. 2: 235]. Образ птицы в сознании Катерины ассоциируется с представлением о свободе, о жизни без морального подавления, в заботе и любви. Такой была жизнь Катерины в её счастливом детстве в доме родителей: «Я жила, ни об чём не тужила, точно птичка на воле» [Островский, 1959. Т. 2: 235]. И сны героини - о полёте: «А то будто я летаю, так и летаю по воздуху» [Островский, 1959. Т. 2: 236]. В устах Катерины оживает образ русской птицы-тройки: «...Кабы моя воля, каталась бы я теперь по Волге, на лодке с песнями, либо на тройке на хорошей, обнявшись...» [Островский, 1959. Т. 2: 237]. Тема полёта человеческой души после смерти оживает в стремлении Катерины обратиться бабочкой: «...Полетела бы невидимо, куда захотела» [Островский, 1959. T. 2: 250]. Тема полёта связана с образом Катерины на протяжении всей пьесы: душа её воспаряет над миром во время молитвы в церкви: «...В солнечный день из купола такой светлый столб вниз идёт, и в этом столбе ходит дым, точно облака, и вижу я, бывало, будто ангелы в этом столбе летают и поют» [Островский, 1959. Т. 2: 236]. Предчувствуя трагедию, Катерина говорит: «А уж коли очень мне здесь опостынет, так не удержат меня никакой силой. В окно выброшусь, в Волгу кинусь» [Островский, 1959. T. 2: 244].

С образом Веры в «Обрыве» связано множество мифологических персонажей: русалка, кошка, змея, птица. Все эти персонажи в народной культуре многозначны. Змея, например, «относится к животным, чья символика обнаруживает сильнейшие контрасты»: «Быстрая, обладающая яркой окраской зловещая и опасная змея вызывает почитание и отвращение» [Луркер: 72]. Образ птицы тоже многозначен. Славяне образ птицы часто связывали с чем-то недобрым и нечистым: бурей, болезнью. Холеру народ представлял в образе «огромной чёрной птицы, летающей по ночам»: «Также и чуму считают летающею уткою, у которой хвост и голова змеиные, т. е. образ птицы сливают в одно представление с образом мифического змея» [Афанасьев. Т. 1: 528-529]. 
Уже в маленькой девочке Райский увидел птицу: «Верочка походила на молодую птичку среди этой ветоши и не смущалась ни преследующими взглядами портретов, ни сыростью, ни пылью, всем этим печальным запустением» [Гончаров, 2004. Т. 7: 77]. Взрослая Вера в романе сравнивается одновременно со змеёй и птицей. Вера не просто ходит, но «скользит, как змея, с обрыва вниз» [Гончаров, 2004. Т. 7: 572], «гнездится» в старом мрачном, холодном каменном доме [Гончаров, 2004. Т. 7: 399], «уползает» в тёмную аллею [Гончаров, 2004. Т. 7: 576], «шипит» [Гончаров, 2004. Т. 7: 601, 686]; Вера, «как птица... точно упала с обрыва в кусты» [Гончаров, 2004. Т. 7: 463]; её «тонкие пальцы, как когти хищной птицы» [Гончаров, 2004. Т. 7: 573], впиваются в плечо Райского; «как освобожденная из клетки птица», Вера бросается навстречу Марку [Гончаров, 2004. Т. 7: 604]. Образ хищной птицы, связанный с Верой, напоминает орла. «Орёл и змея - общемировые оппозиционные символы... <..> ...полёт - стремление ввысь, к солнцу, свету - добро; ползание, прятанье в расселинах, во тьме - зло. Тем более, что именно змея, не орёл, угрожает человеческой жизни», - пишет В. К. Афанасьева [Афанасьева: 9]. «Птица борющаяся со змеёй... означает преодоление низменных инстинктов посредством духовного начала» [Бидерман: 216]. В сознании Веры происходит именно такая борьба, духовное начало в этой борьбе одерживает верх. После разрыва с Марком, пережитой драмы автор намеренно противопоставляет в Вере змеиное и человеческое: теперь она подходит к Райскому «не прежним ползучим шагом, не с волнующимся при походке станом, а тихой, ровной поступью» [Гончаров, 2004. Т. 7: 712]. Из хищной ночной птицы Вера превращается в птицу райскую, подобную Марфиньке: слова Веры о том, что она разлюбила Марка, не может быть счастлива с ним, «бабушка слушала, притаив дыхание, как пение райской птицы» [Гончаров, 2004. Т. 7: 708]. Теперь Вера сравнивается с лилией [Гончаров, 2004. Т. 7: 711]; в христианстве этот цветок является символом «чистой, девственной любви. <..> ...змеи избегают лилий, которые издают услаждающий сердце запах» [Бидерман: 216, 149].

В «Бесприданнице» прямые ассоциации с образом птицы возникают уже потому, что имя Лариса означает «чайка» [Жития Святых: 681]. В начале пьесы её манит «вид на Волгу, на большое пространство: леса, сёла и проч.» [Островский, 1960. Т. 8: 7], там она хочет обрести душевный покой. В финале пьесы волжский обрыв для неё - возможность 
спасения от пошлости жизни. Однако воспарить над миром - улететь за Волгу или броситься с волжского берега - Лариса не сможет. Ей принадлежат реплики: «уехать надо, вырваться отсюда» [Островский, 1960. Т. 8: 35], «надо бежать и из дому, и даже из города» [Островский, 1960. Т. 8: 45], «так бы убежала куда-нибудь» [Островский, 1960. Т. 8: 53], Вырваться из этого мира, «воспарить» над ним душой героиня сможет только после выстрела Карандышева. Об этом говорят её последние слова, обращённые к жениху: «Милый мой, какое благодеяние вы для меня сделали! <..> Вам надо жить, а мне надо... умереть.. <..> ...я вас всех... всех люблю» [Островский, 1960. Т. 8: 87].

Вера у Гончарова несомненно ближе Ларисе Островского. Возможно, образ девушки-дворянки, героини-птицы в «Бесприданнице» и навеян образом Веры. Различие в судьбах героинь определяется во многом не просто разными истоками образов Веры и Ларисы, но и представлениями писателей о будущем России. Островский был убеждён, что с распадом патриархальных отношений разрушаются нравственные устои общества, Гончаров же верил в благоприятное влияние на русскую жизнь реформ царя-освободителя.

Заключая, обратим внимание на очевидность некоторых созвучий в понимании и способах изображения Петербурга и Москвы, их обитателей, в раскрытии темы провинции в творчестве Островского и Гончарова, что, несомненно, подтверждает творческую близость этих художников, приверженных разным литературным родам - драме и эпосу. 


\section{Список литературы}

Афанасьев А. Н. Поэтические воззрения славян на природу: В 3 т. Т. 1. М.: Индрик, 1994. $806 \mathrm{c}$.

Афанасьева В. К. Орёл и змея в изобразительности и литературе Двуречья. М.: Водолей Publichers, 2007. 468 c.

Белкин Д. И. Образ Волги-реки в структуре романа И. А. Гончарова «Обрыв» // И. А. Гончаров. Материалы международной конференции, посвящённой 185-летию со дня рождения И. А. Гончарова: Сборник русских и зарубежных авторов. Ульяновск, 1998. С. 186-195.

Беляева И. А. Москва в жизни и творчестве И. А. Гончарова: на пути от провинции к столице // Москва и «московский текст». Москва в судьбе и творчестве русских писателей. Сборник научных статей. Вып. 7. М.: МГПУ, 2013. С. 4-14.

Бидерман Г. Энциклопедия символов. М.: Республика, 1996. 334 с.

Гачев Г. Национальные образы мира: Космо - Психо - Логос. М.: Прогресс, 1995. $479 \mathrm{c}$.

Гончаров И. А. Собрание сочинений: В 8 т. М.: Правда, 1952. (Библиотека «Огонёк»).

Гончаров И. А. Полное собрание сочинений и писем: В 20 т. СПб.: Наука, 1997-.

Доманский В. А. Петербургский текст в романах И. А. Гончарова // Гончаров: Живая перспектива прозы. Научные статьи о творчестве И. А. Гончарова. Szombathely, 2013. C. 49-57.

Ермолаева Н. Л. Потаённый смысл образа камня в произведениях И А Гончарова 1840-50-х годов // Потаённая литература: Исследования и материалы. Приложение к выпуску 2. Иваново, 2000. С. 154-161.

Ермолаева Н. Л. Роман И. А. Гончарова «Обломов» на уроках литературы // Литература в школе. 2009. № 2. С. 26-30.

Жития Святых / Сост. священник и законоучитель Иоанн Бухарев. М.: Отчий дом, 1999. $694 \mathrm{c}$.

Журавлёва А. И. А. Н. Островский - комедиограф. М.: МГУ, 1981. 216 с.

Журавлёва А. И. Александр Николаевич Островской // История русской литературы XIX века. Вторая половина / Под ред. Н. Н. Скатова. М.: Просвещение, 1987. C. $230-284$.

Журавлёва А. И. Русская драма и литературный процесс XIX века. М.: Изд. МГУ, 1988. $200 \mathrm{c}$.

Загоскин М. Н. Москва и москвичи. М.: Абрис/ОЛМА. 2019. 256 с.

Капустин Н. В. Об инфернальном в художественном мире А. Н. Островского // Филологические науки. 2016. № 4. С. 56-62.

Краснощёкова Е. А. Иван Александрович Гончаров: Мир творчества. СПб.: Пушкинский фонд, 1997. 496 с.

Криволапов В. Н. «Типы» и «Идеалы» Ивана Гончарова. Курск, 2001. 280 с.

Лебедев Ю. В. Православная традиция в русской литературе XIX века: Сб. науч. ст. Кострома: КГУ им. Н. А. Некрасова, 2010. 428 с.

Луркер Манфред. Египетский символизм: Сер. «Символы». Кн. IX. М.: Ассоциация Духовного Единения «Золотой Век», 1998. 184 с. 


\section{Русская литература XVIII и XIX столетий \\ Н. Л. Ермолаева. Петербург, Москва, провинция в творчестве ...}

Люсый А. П. Московский текст: текстологическая концепция русской культуры. М.: Вече Русский импульс, 2013. 317 с.

Медведев А. В. Новое небо: петербургский текст в литературе и искусстве. Сборник статей. СПб.: Сезам-Принт, 2012. 174 с.

Мосалёва Г. В. Поэзия предания в «московских» пьесах А. Н. Островского: мир русской глубинки // Вестник Удмуртского университета. Серия «История и филология». 2015. Т. 25. Вып. 5. С. 108-113.

Москва и московский текст русской культуры: Сб. ст / [Рос. гос. гуманит. ун-т ; Отв. ред. Г. С. Кнабе]. М.: Изд. центр РГГУ, 1998. 225 с.

Москва и «московский текст» в русской литературе и фольклоре. М.: МГПУ, 2004. 243 c.

Москва и «московский текст» в русской литературе XX века: материалы Международной научной конференции / IX Виноградовские чтения. М.: МГПУ, 2007. 121 с.

Москва и «московский текст» в русской литературе. Москва в судьбе и творчестве русских писателей: материалы межвузовского научного семинара. Вып. 5. М.: МГПУ, 2010. 191 с.

Москва и «московский текст» в русской литературе. Москва в судьбе и творчестве русских писателей. Вып. 6: сборник научных статей. М.: МГПУ, 2012. 170 с.

Москва и «московский текст» в русской литературе. Москва в судьбе и творчестве русских писателей: материалы межвузовского научного семинара. Вып.7. М.: МГПУ, 2013. 136 с.

Москва и «московский текст» в русской литературе. Москва в судьбе и творчестве русских писателей: материалы межвузовского научного семинара Вып. 8: сборник научных статей. М.: МГПУ, 2015. 137 с.

Ожимкова В. В. «А у нас за Москвой-рекой...» (Москва в судьбе и произведениях А. Н. Островского) // А. Н. Островский. Материалы и исследования. Сборник научных трудов. Шуя, 2006. С. 232-240.

Островский А. Н. Собрание сочинений: в 10 т. М.: ГИХЛ, 1959-1960.

Островский А. Н. Полн. собр. соч.: в 12 т. М.: Искусство. 1973-1980.

Ревякин А. И. Москва в жизни и творчестве А. Н. Островского. М.: Московский рабочий, $1962.544 \mathrm{c}$.

Роговер Е. С. Петербургский текст русской литературы: монография. СПб.: Шатон, 2006. 209 c.

Существует ли Петербургский текст? Петербургский сборник. Вып. 4. СПб.: Изд. Санкт-Петербургского ун-та, 2005. 402 с.

Топоров В. Н. Петербург и «Петербургский текст русской литературы» (Введение в тему) // Топоров В. Н. Миф. Ритуал. Символ. Образ: Исследования в области мифопоэтического: Избранное. М.: Издательская группа «Прогресс» - «Культура», 1995. С. 259-367.

Федотов Г. П. Три столицы // Судьба и грехи России. СПб.: София, 1991. С. 56-57.

Цветкова Е. В. Тема Волги в творчестве А. Н. Островского (Топонимический этюд) // А. Н. Островский в движении времени. Материалы всероссийской научной конференции. Т. 1. Шуя, 2003. С. 114-121.

Цейтлин А. Г. И. А. Гончаров. М.: Изд. АН СССР, 1950. 491 с. 


\section{References}

Afanas'ev A. N. Poeticheskie vozzreniia slavian na prirodu: V 3 t. T. 1. [Poetic views of the slavs on nature: in 3 vols. Vol. 1]. Moscow, Indrik Publ., 1994. 806 p. (In Russ.)

Afanas'eva V. K. Orel i zmeia v izobrazitel'nosti i literature Dvurech'ia [The hawk and the snake in the pictorial culture and literature of esopotamia]. Moscow, Vodolei Publ., 2007. 468 p. (In Russ.)

Belkin D. I. Obraz Volgi-reki v strukture romana I. A. Goncharova "Obryv" [The image of Volga in the structure of the novel "Obryv (Precipice)" by I. A. Goncharov]. I. A. Goncharov. Materialy mezhdunarodnoi konferentsii, posviashchennoi 185-letiiu so dnia rozhdeniia I. A. Goncharova: Sbornik russkikh i zarubezhnykh avtorov [I. A. Goncharov. Materials of the international conference, devoted to the 185 jubilee of the day of birth of I. A. Goncharov: the collection of Russian and foreign authors]. Ul'ianovsk, 1998, pp. 186-195. (In Russ.)

Beliaeva I. A. Moskva $v$ zhizni i tvorchestve I. A. Goncharova: na puti ot provintsii $k$ stolitse [Moscow in the life and creative work by I. A. Goncharov: on the way from province to capital]. Moskva i "moskovskii tekst". Moskva v sud'be i tvorchestve russkikh pisatelei. Sbornik nauchnykh statei. Vyp. 7 [Moscow and "Moscow text". Moscow in the life and creative work of the Russian writers. Collection of scientific articles. Iss. 7]. Moscow, MGPU Publ., 2013, pp. 4-14. (In Russ.)

Biderman G. Entsiklopediia simvolov [The encyclopedia of symbols]. Moscow, Respublika Publ., 1996. 334 p. (In Russ.)

Gachev G. Natsional'nye obrazy mira: Kosmo - Psikho - Logos [National images of the world: Cosmo - Psycho - Logos]. Moscow, Progress Publ., 1995. 479 p. (In Russ.).

Goncharov I. A. Sobranie sochinenii: $V 8 t$. [Collection of works: in 8 vols.] Moscow, Pravda Publ., 1952. (Biblioteka “Ogonek"). (In Russ.)

Goncharov I. A. Polnoe sobranie sochinenii i pisem: V 20 t. [Complete works and letter by I. A. Goncharov: in 20 vols.]. Sankt-Peterburg, Nauka Publ., 1997-. (In Russ.)

Domanskii V. A. Peterburgskii tekst v romanakh I. A. Goncharova [Petersburg text in the novels by I.A.Goncharov]. Goncharov: Zhivaia perspektiva prozy. Nauchnye stat'i $o$ tvorchestve I. A. Goncharova [Goncharov: the living perspective of the prose. Scientific articles on the creative works by I. A. Goncharov]. Szombathely, 2013, pp. 49-57. (In Russ.)

Ermolaeva N. L. Potaennyi smysl obraza kamnia v proizvedeniiakh I. A. Goncharova 1840-50-kh godov [The secret sense of the image of the stone in the works by I. A. Goncharov of the 1840-50s]. Potaennaia literatura: Issledovaniia i materialy [The secret literature: research and materials. 2]. Appendix to issue Ivanovo, 2000, pp. 154161. (In Russ.)

Ermolaeva N. L. Roman I. A. Goncharova "Oblomov" na urokakh literatury [The novel "Oblomov" by I. A. Goncharov at the classes of literature]. Literatura $v$ shkole [Literature in school]. 2009. № 2, pp. 26-30. (In Russ.)

Zhitiia Sviatykh, Sost. sviashchennik i zakonouchitel' Ioann Bukharev [The lives of saints. Collected by the priest and law-teacher Ioann Bukharev]. Moscow, Otchii dom Publ., 1999. 694 p. (In Russ.)

Zhuravleva A. I. A. N. Ostrovskii - komediograf [A. N. Ostrovsky - the comedian]. Moscow State University Publishing Publ., 1981. 216 p. (In Russ.) 
Zhuravleva A. I. Aleksandr Nikolaevich Ostrovskoi [Alexander Nikolaevich Ostrovsky]. Istoriia russkoi literatury XIX veka. Vtoraia polovina. [The history of Russian literature of the XIX century. The second half.]. Ed. by N. N. Skatov Moscow, Prosveshchenie Publ., 1987, pp. 230-284. (In Russ.)

Zhuravleva A. I. Russkaia drama i literaturnyi protsess XIX veka [Russian drama and the literary process of the XIX century]. Moscow, Moscow State University Publishing Publ., 1988. 200 p. (In Russ.)

Zagoskin M. N. Moskva i moskvichi [Moscow and the Moscovites]. Moscow, Abris/ OLMA Publ., 2019. 256 p. (In Russ.)

Kapustin N. V. Ob infernal'nom v khudozhestvennom mire A. N. Ostrovskogo [On the infernal in the artistic world of A. N. Ostrovsky]. Filologicheskie nauki [Philological sciences]. 2016. № 4, pp. 56-62. (In Russ.)

Krasnoshchekova E. A. Ivan Aleksandrovich Goncharov: Mir tvorchestva [Ivan Alexandrovich Goncharov: The world of creative work]. Sankt-Peterburg, Pushkin fund Publ., 1997. 496 p. (In Russ.)

Krivolapov V. N. "Tipy" i "Idealy" Ivana Goncharova ["Types" and "Ideals" of Ivan Goncharov]. Kursk, 2001. 280 p. (In Russ.)

Lebedev Iu. V. Pravoslavnaia traditsiia v russkoi literature XIX veka: Sb. nauch. st. [Orthodox tradition in the Russian literature of the XIX century: collection of scientific articles]. Kostroma, N. A. Nekrasov Kostroma State University Publ., 2010. 428 p. (In Russ.)

Lurker Manfred. Egipetskii simvolizm: Ser. "Simvoly”. Kn. IX [Egyptian symbolism: Series “Symbols”. Book IX]. Moscow, Assotsiatsiia Dukhovnogo Edineniia “Zolotoi Vek" Publ., 1998. 184 p. (In Russ.)

Liusyi A. P. Moskovskii tekst: tekstologicheskaia kontseptsiia russkoi kul'tury [Moscow text: textological conception of the Russian culture]. Moscow, Veche Russkii impul's Publ., 2013. 317 p. (In Russ.)

Medvedev A. V. Novoe nebo: peterburgskii tekst $v$ literature $i$ iskusstve: Sbornik statei [The New heavens: Petersburg text in the literature and art: collection of articles]. SanktPeterburg, Sezam-Print Publ., 2012. 174 p. (In Russ.)

Mosaleva G. V. Poeziia predaniia v “moskovskikh” p'esakh A. N. Ostrovskogo: mir russkoi glubinki [The poetry of the legend in the "Moscow" plays by A. N. Ostrovsky: the world of Russian province]. Vestnik Udmurtskogo universiteta. Seriia "Istoriia i filologiia" [Bulletin of the Udmurt University. Series “History and philology”]. 2015. № 5, pp. 108113. (In Russ.)

Moskva i moskovskii tekst russkoi kul'tury [Moscow and "Moscow text" in the Russian literature: collection of articles [Russian State Humanitarian Institute; Chief editor G.S. Knabe]]. Moscow, Publishing centre of the Russian State Humanitarian Institute Publ., 1998. 225 p. (In Russ.)

Moskva i "moskovskii tekst" $v$ russkoi literature i fol'klore [Moscow and "Moscow text" in the Russian literature and folklore. Collection of materials. The VIIth international Vinogradov's seminar. Moscow, Moscow State Pedagogical University Publ., 2004. 243 p. (In Russ.) 
Moskva i "moskovskii tekst" v russkoi literature XX veka. [Moscow and "Moscow text" in the Russian literature of the XX century] Materials of the scientific conference, X Vinagradov's seminar. Moskva, Moscow State Pedagogical University Publ., 2007. 121 p. (In Russ.)

Moskva i "moskovskii tekst" v russkoi literature. Moskva v sud'be i tvorchestve russkikh pisatelei: materialy mezhvuzovskogo nauchnogo seminara [Moscow and "Moscow text" in the Russian literature. Moscow in the life and creative work of Russian writers]. Materials of the international scientific seminar. Iss. 5. Moscow, Moscow State Pedagogical University Publ., 2010. 191 p. (In Russ.)

Moskva i "moskovskii tekst" v russkoi literature. Moskva v sud'be i tvorchestve russkikh pisatelei [Moscow and "Moscow text" in the Russian literature. Moscow in the life and creative work of Russian writers.]. Iss. 6: collection of scientific articles Moscow, Moscow State Pedagogical University Publ., 2012. 170 p. (In Russ.)

Moskva i "moskovskii tekst" v russkoi literature. Moskva v sud'be i tvorchestve russkikh pisatelei [Moscow and "Moscow text" in the Russian literature. Moscow in the life and creative work of Russian writers]. Materials of the international scientific seminar. Iss. 7. Moscow, Moscow State Pedagogical University Publ., 2013. 136 p. (In Russ.)

Moskva i "moskovskii tekst" v russkoi literature. Moskva v sud'be i tvorchestve russkikh pisatelei [Moscow and "Moscow text" in the Russian literature. Moscow in the life and creative work of Russian writers]. Materials of the international scientific seminar. Iss. 8: collection of scientific articles. Moscow, Moscow State Pedagogical University Publ., 2015. 137 p. (In Russ.)

Ozhimkova V. V. “A u nas za Moskvoi-rekoi...” (Moskva v sud'be i proizvedeniiakh A. N. Ostrovskogo) ["As we have it behind the Moscow-river" (Moscow in the life and works by A. N. Ostrovsky)]. A. N. Ostrovskii. Materialy i issledovaniia. Sbornik nauchnykh trudov [A. N. Ostrovsky. Materials and research. A collection of scientific works]. Shuia, 2006, pp. 232-240. (In Russ.)

Ostrovskii A. N. Sobranie sochinenii: $v 10 t$ [Collection of works: in 10 vols.]. Moscow, State publishing of the fiction literature Publ., 1959-1960. (In Russ.)

Ostrovskii A. N. Poln. sobr. soch.: v 12 t. [Complete edition of works: in 12 vols. Vol. 10]. Moscow, Iskusstvo Publ., 1973-1980. (In Russ.)

Reviakin A. I. Moskva v zhizni i tvorchestve A. N. Ostrovskogo [Moscow in the life and creative work of A. N. Ostrovsky]. Moscow, Moskovskii rabochii Publ., 1962. 544 p. (In Russ.)

Rogover E. S. Peterburgskii tekst russkoi literatury [Petersburg text of the Russian literature]. Sankt-Peterburg, Shaton Publ., 2006. 209 p. (In Russ.)

Sushchestvuet li Peterburgskii tekst? Peterburgskii sbornik [Is there a Petersburg text? The Petersburg collection]. Vol. 4. Sankt-Peterburg, Sankt-Peterburgskogo un-ta Publ., 2005. 402 p. (In Russ.)

Toporov V. N. Peterburg i "Peterburgskii tekst russkoi literatury" (Vvedenie v temu) [Petersburg and Petersburg text of the Russian literature (Introduction into the theme)]. Toporov V. N. Mif. Ritual. Simvol. Obraz: Issledovaniia v oblasti mifopoeticheskogo: Izbrannoe. [Myth. Ritual. Symbol. Image. Studies in the sphere of mythpoetics] Moscow, Izdatel'skaia gruppa “Progress' - “Kul'tura' Publ., 1995, pp. 259-367. (In Russ.) 
Fedotov G. P. Tri stolitsy [Three capitals]. Sankt-Peterburg, Sofiia Publ., 1991, pp. 5657. (In Russ.)

Tsvetkova E. V. Tema Volgi v tvorchestve A. N. Ostrovskogo (Toponimicheskii etiud) [The theme of Volga in the creative work of A. N. Ostrovsky (a toponymical essay). A. N. Ostrovskii v dvizhenii vremeni. [A. N. Ostrovsky in the course of time]. T. 1. Shuia, 2003, pp. 114-121. (In Russ.)

Tseitlin A. G. I. A. Goncharov [I. A. Goncharov]. Moscow, AN SSSR Publ., 1950. 491 p. (In Russ.) 
(c) 2019. А. Кавацца

г. Урбино, Италия

\title{
Образ Марии Египетской в творчестве $Ф$. М. Достоевского
}

\begin{abstract}
Аннотация: В статье анализируется образ христианской святой Марии Египетской и использование этого образа Ф. М. Достоевским как в черновиках и подготовительных заметках, так и в текстах художественных произведений. Согласно исследованию автора, образ Марии Египетской появляется уже на страницах ранних произведений Достоевского (впервые в рассказе 1848 г.) и используется писателем на протяжении всего творческого пути. В ходе изучения упоминаний Достоевским этой святой становится понятно, что все они связаны с мыслью о кардинальном изменении жизни героев, с совершением ими подвига. Образ раскаявшейся и вновь нашедшей Бога грешницы помогает писателю представить единственный возможный путь, подходящий для заблуждающихся и ошибающихся героев. Образ Марии Египетской раскрывает дорогую для Достоевского тему преображения и духовного возрождения человека, а также идею владения собой, борьбы со страстями и дурными наклонностями человеческого естества.
\end{abstract}

Ключевъе слова: Достоевский, Мария Египетская, христианские святые, образы грешников, блудница, мотив искупления, возрождение героев

Информация об авторе: Антонелла Кавацца, доцент славистики, Урбинский университет им. Карло Бо, г. Урбино, Италия

E-mail: antonella.cavazza@uniurb.it

Дата поступления статьи в редакиию: 21.10 .2019

Дата публикации статьи: 10.12.2019

Для изитирования: Кавацца А. Образ Марии Египетской в творчестве Ф. М. Достоевского // Два века русской классики. 2019. Т. 1. № 2. С. 174-185. DOI 10.22455/26867494-2019-1-2-174-185 
This is an open access article distributed under the Creative Commons Attribution 4.0 International (CC BY 4.0)

(C) 2019. A. Kavazza

Urbino, Italy

\section{The image of Mary of Egypt in the work of F. M. Dostoevsky}

Annotation: The article analyzes the image of Christian St. Mary of Egypt and the use of this image by F. M. Dostoevsky both in draft and preparatory notes, and in the texts of fiction. According to the author's research, the image of Mary of Egypt appears on the pages of the early works of Dostoevsky (for the first time in the story of 1848) and is used by the writer throughout his career. In the course of studying the references to this saint by Dostoevsky, it becomes clear that they are all connected with the idea of a radical change in the lives of heroes, with the accomplishment of their feat. The image of the repentant and newly found God sinner helps the author to imagine the only possible way, suitable for erring and mistaken heroes. The image of Mary of Egypt reveals a topic that is dear to Dostoevsky. The topic of transfiguration and spiritual rebirth of a man, as well as the idea of self-control, the struggle with passions and evil inclinations of human nature.

Keywords: Dostoevsky, Mary of Egypt, Christian saints, images of sinners, harlot, motive of redemption, revival of heroes

Information about the author: Kavazza A., Associate professor in Slavic Studies, University of Carlo Bo, Urbino, Italy

E-mail: antonella.cavazza@uniurb.it

Received: October 21, 2019

Published: December 10, 2019

For citation: Kavazza A. The image of Mary of Egypt in the work of F. M. Dostoevsky. Two centuries of the Russian classics, 2019, vol. 1, № 2, pp. 174-185. (In Russ.) DOI 10.22455/2686-7494-2019-1-2-174-185 
Образ преподобной Марии Египетской ${ }^{1}$ встречается в нескольких произведениях Ф. М. Достоевского. Возникает естественный вопрос: что писатель хотел привнести в характеры своих персонажей, упоминая имя этой христианской святой? Возможно ли узнать, каким образом Достоевский познакомился с жизнеописанием этой отшельницы? Целью нашей статьи являются ответы на эти вопросы.

Впервые в произведениях Достоевского имя Марии Египетской упоминается в рассказе 1848 г. «Ползунков». По православному календарю День памяти этой святой приходится на первое апреля, дату, которая является ключевой для хронологии рассказа. Автор в данном случае реализует двойной смысл, религиозный и мирской, связанный с числом первое апреля. Общеизвестно, что во многих странах в этот день разыгрываются разного рода шутки, в том числе и недобрые. Собственно, недобрая шутка произошла и с главным героем рассказа. Случилось так, что накануне первого апреля герой решает признаться в шантаже и покаяться в этом. Кажется, Ползунков поддержан в этом своем намерении также и Федосеем Николаичем, его начальником и будущим тестем, который обращается к нему со следующими словами:

- Вижу, — говорит Федосей Николаич, — вижу Ваше раскаяние ... вы, знаете, завтра...

- Марии Египетские-с ...

- Ну не плачь, — говорит Федосей Николаич, — полно: согрешил и покаялся! пойдём! Может быть, удастся мне возвратить, говорит, вас на путь

\footnotetext{
1 Преподобная Мария, прозванная Египетской, жила в середине V в. и в начале VI в. Согласно западным источникам, она жила между IV и V вв. (Александрия, около 344 г.- около 2 апреля 421 г.).

Определение сроков жизни преподобной Марии Египетской является спорным вопросом. Мария Египетская родилась в Египте, жила в Александрии. Она обратилась к Богу необычным путём. Проведя в Александрии молодость блудницей, во время путешествия в Иерусалим она осознала свои грехи, раскаялась и удалилась в пустыню, где прожила 47 лет.
} 
истинный ... Может быть, скромные пенаты мои (именно, помню, пенаты, так и выразился, разбойник) согреют, говорит, опять ваше очерств ... не скажу очерствелое, заблудшее сердце» [Достоевский. Т. 2: 9].

Но на следующий день Ползунков попадает в ловушку Федосея Николаича, которую частично сам главный герой и помог создать. Благодаря своей хитрости, Федосей Николаич избавляется от Ползункова как от сотрудника и будущего зятя.

Первого апреля Ползунков пишет шутливое письмо о своем увольнении и отдает его Федосею Николаичу. К своему большому изумлению, Ползунков вскоре узнаёт, что последний только делал вид, что простил его. В реальности же начальник действительно запустил процесс увольнения, лишая автора письма сразу и работы, и невесты. Создаётся впечатление, что в рассказе, особенно в его конце, религиозная составляющая даты первое апреля уступает мирскому значению, шуточному, в том числе - неуместно шуточному и злому. Достоевский не случайно в начале рассказа называет Ползункова «самым бесполезнейшим и, следовательно, самым комическим мучеником».

Второе упоминание о преподобной Марии Египетской встречается в романе «Преступление и наказание». На встрече с Родионом Раскольниковым Свидригайлов в ироническом ключе упоминает раннехристианских мучениц и отшельниц, которые жили в Египетской пустыне. Важно, что герой сравнивает с ними целомудрие Авдотьи Романовны. Вспоминая о преподобной Марии, Свидригайлов путает место ее рождения - Египет с Палестиной - местом, куда она ушла в пустыню: «Она (Дуня - А. К.), без сомнения, была бы одна из тех, которые претерпели мученичество, и уж, конечно бы, улыбалась, когда бы ей жгли грудь раскаленными щипцами. Она бы пошла на это нарочно сама, а в четвертом и в пятом веках ушла бы в Египетскую пустыню и жила бы там тридцать лет, питаясь кореньями, восторгами и видениями» [Достоевский. Т. 6: 365] ${ }^{1}$. В устах этой мефи-

\footnotetext{
1 Книга «Aрophthegmata Patrum» или «Высказывания отцов пустыни» повествует, что в Египетскую пустынь в IV-V вв. ушли и другие женщины: Теодора, Сарра и Синклетика, ставшие образцами духовных матерей. Славянские переводы текстов «Ароphthegmata Patrum» вошли в состав различных патериков. В «Древнем патерике», помимо отшельниц, которые в египетской пустыне скрыли свою личность под мужской монашеской одеждой, упоминается также Мария Египетская, житие которой с VI в. стало очень известным в монашеской среде.
} 
стофельской личности ${ }^{1}$ эти слова указывают, насколько широко история жизни Марии Египетской была в то время известна в России. Есть еще более глубокое объяснение этому упоминанию, которое перекликается с событиями, рассказанными в конце «Преступления и наказания». В работе «История создания романа» Л. Д. Опульская отметила, что в образе Свидригайлова воплощалась идея «великого грешника». Она пишет: «В самом раскаянии Раскольникова, в последних переживаниях его, Свидригайлову отводилась все бо́льшая роль. Соня и Свидригайлов - как бы две стороны души Раскольникова» [Громова-Опульская: 703]. По этому поводу прямо сказано на последних страницах подготовительных материалов к роману, где в разделе записной тетради, названной «Финал романа» читаем:

«Свидригайлов - отчаяние, самое циническое.

Соня - надежда, самая неосуществимая.

(Это должен высказать сам Раскольников)» [Достоевский. Т. 7: 204].

В подготовительных материалах к роману «Преступление и наказание» Достоевский неоднократно возвращался к характеристике этого персонажа. Описывая его добрые и злые, прекрасные и отвратительные порывы, определявшиеся страстностью его натуры, Достоевский колебался в определении судьбы этого героя [Громова-Опульская: 704-705]. По этому поводу интересно вспомнить, что в самой первой характеристике Свидригайлова Достоевский записал: «Выгнал или убил приживальщика. Бес мрачный, от которого не может отвязаться. Вдруг решимость изобличить себя, всю интригу; покаяние, смирение, уходит, делается великим подвижником, смирение, жажда претерпеть страдание. Себя предает. Ссылка. Подвижничество» (курсив Достоевского - А. К.) [Достоевский. Т. 7: 156]. В окончательном тексте романа, как отметила Н. А. Тарасова, преобладает надежда на обновление жизни [Taрасова, 2017: 279]. В финале романа покаянную роль выполнит не Свидригайлов, который покончит жизнь самоубийством, а Раскольников.

Кроме явного упоминания о преподобной Марии Египетской в шестой части четвёртой главы романа, в эпилоге «Преступления и наказания» есть и косвенная ссылка на неё. Кульминация внутреннего кризиса главного героя в эпилоге романа, предшествующая его моральному

1 Слова Свидригайлова «...не привилегию же в самом деле взял я делать одно только злое» являются перифразом известных слов Мефистофеля в «Фаусте» Гете: «Я - часть той силы, что вечно хочет зла и вечно совершает благо». 
перерождению, приходится на конец поста и Святую неделю: «Он пролежал в больнице весь конец поста и святую» [Достоевский. Т. 6: 419]. ${ }^{1}$ Именно в пятую неделю Великого поста, в среду вечером на утрене Православная Церковь упоминает преподобную, поэтому литургия и называется Стояние Марии Египетской. Внутреннее преображение, как заключает Достоевский в «Преступлении и наказании», потребует неизбежного подвига от того, кто желает примириться с Богом: «Он даже и не знал того, что новая жизнь не даром же ему достается, что ее надо ещё дорого купить, заплатить за нее великим, будущим подвигом ...» [Достоевский. Т. 6: 422]. Подвигом, подобным подвигу раннехристианских отшельников, особенно подвигу преподобной Марии Египетской. Слово это имеет глубокое религиозное значение. «Подвиг» - это ключевое слово, которое встречается не только в подготовительных материалах к «Преступлению и наказанию», но также и в записных книжках к роману «Бесы» Достоевского. В подготовительных материалах к «Бесам», в записи, названной «К фантастической странице», читаем:

«Князь: 'Нужен подвиг. Пусть же русская сила и покажет, что может сделать его. Подвигом мир победите'. Шатов странно задумался:

- Знаете, всё это одни фантазии, - сказал он, — тоже книги или ... или религиозное помешательство. Привлеките-ка всех к подвигу.

Кн<язь>: 'Зачем всех. Поверите ли, как может быть силен один человек. Явись один, и все пойдут. Нужно самообвинение и подвиги, идея эта нужна, иначе не найдем православия и ничего не будет'» [Достоевский. Т. 11: 177]².

Третье упоминание о святой мы видим в черновике последнего романа - «Братья Карамазовы», в главе «Исповедь старца», где речь идет о преподавании Закона Божьего и Таинства крестьянским детям, по-

1 В четвёртой главе четвёртой части, по просьбе Родиона, Соня вслух читает ему Евангелие от Иоанна, интонационно подчёркивая то место, где Иисус Христос просит убрать могильную плиту. Сестра Лазаря возражает ему, что тело уже четыре дня как погребено. Как заметил М. С. Альтман, те же четыре дня прошли с момента убийства Раскольниковым старухи-процентщицы и ее сестры Елизаветы. Чтение вслух евангельского эпизода пробуждает совесть Раскольникова и ведёт его к моральному воскрешению, описанному в эпилоге романа [Альтман: 32].

2 Об особенном значении корпуса записей, который Достоевский выделил тематически и назвал их «Фантастическими страницами» см. [3ахаров, 2008: 390]. 
скольку библейские рассказы могут кардинально изменить их жизнь. Заметим, что здесь имя Марии Египетской упомянуто в числе других назидательных примеров, предлагаемых для следования им не только детям, но и взрослым: «А с детьми видал я духовных: учат закону, что есть причастье, на текстах, катехизис. Пусть это в школах. То ли надо бедному деревенскому мальчику; прочти ты ему всю историю, как Иаков пошел к Лавану, как Иосиф прекрасный, Алексея, человека божьего, Марию Египетскую - на всю жизнь его переменишь» [Достоевский. Т. 15: 253]. В окончательной редакции романа «Братья Карамазовы» этот совет становится частью проповеди старца Зосимы, который рекомендует священникам читать простому народу прежде всего истории из Священного писания: рассказ про Абрама и Сарру, про Исаака и Ревекку, а также истории и рассказы «Четьих Миней»: «Не забудьте тоже притчи господни, преимущественно по Евангелию от Луки (так я делал), а потом из Деяний апостольских обращение Савла (это непременно, непременно!), а наконец, и из Четьих-Миней хотя бы житие Алексия, человека Божия и великой из великих радостной страдальницы, боговидицы и христоносицы матери Марии Египтяныни - и пронзишь ему сердце его сими простыми сказаниями, и всего-то лишь час в неделю, невзирая на малое свое содержание, один часок» [Достоевский. Т. 14: 267]. Учитывая тот факт, что в тропаре, посвящённом Марии Египетской, она зовётся «Матерью покаяния», присутствие святой на страницах романа объясняется действием в персонажей, склонных ко греху и насилию. Двое из них, Митя и Груша, в ходе повествования внутренне преображаются. Жизнь преподобной, которую автор вспоминает в середине романа, является положительным примером для таких персонажей, как Митя и Груша, ведущих буйную и беспорядочную жизнь, но нашедших в себе силы опомниться и через нравственный подвиг возродиться.

Каким образом Достоевский познакомился с жизнью египетской отшельницы? Автором первого жития является святитель Софроний (560-638), патриарх Иерусалима. Речь идёт о произведении «Житие преподобной матери нашей Марии Египетской», которое в свою очередь является главным источником одноимённого рассказа о жизни преподобной в сборнике «Четьи-Минеи», составленном святителем Димитрием Ростовским (1651-1709). Достоевский, с детства регулярно посещавшиий богослужение, ${ }^{1}$ скорее всего, познакомился с жизнью преподобной Марии

${ }^{1}$ Ср. [Григорьев: 9-12]. 
именно на литургии. Помимо этого мы знаем, что в библиотеке Достоевского имелся сборник «Избранные жития святых, кратко изложенные по руководству Четьих-Миней» (вып. 1-12, 4-ое изд., М.: Тип. Бахметева, 1867-1868) (далее «Избранные жития святых»)․․ Так, сам Достоевский в «Дневнике писателя» объясняет, насколько был популярен этот сборник в православном мире: «По всей земле русской чрезвычайно распространено значение «Четьих-Миней» - о, не всей, конечно, книги, - но распространён дух её по крайней мере» [Достоевский. Т. 25: 214-215]2. Привлекает внимание тот факт, что житие преподобной Марии Египетской из «Четьих-Миней» с 1840 по 1880 гг. несколько раз публиковалось как отдельное издание. ${ }^{3}$ Достоевский сам высоко ценил жития святых из «Четьих-Миней» ${ }^{4}$. Апрель месяц в «Избранных житиях святых» открывается

1 [Библиотека Ф. М. Достоевского: 121]. «Четьи-Минеи» упоминаются и на первых страницах романа «Идиот».

2 Здесь Достоевский добавляет: «Я сам в детстве слышал такие рассказы прежде еще, чем научился читать. Слышал я потом эти рассказы даже в острогах у разбойников, и разбойники слушали и воздыхали. Эти рассказы передаются не по книгам, а заучились изустно. В этих рассказах, и в рассказах про святые места, заключается для русского народа, так сказать, нечто покаянное и очистительное» [Достоевский. T. 25: 214-215]

3 «Жизнь преподобной матери нашей Марии Египетской»: с объяснениями, тропарем и кондаком на славян. и рус. яз. и изображением преподобной: (для нар. чтения). Москва, Тип. Глушкова, 1863; «Жизнь преподобной матери нашей Марии Египетской»: с объяснениями, тропарем и кондаком на славян: (Для нар. чтения). Москва: Издание Тип. Глушкова, 1866; «Жизнь преподобной матери нашей Марии Египетской»: сост. по руководству Четьи-Минеи: (Для нар. чтения). Москва: Манухин, 1867; «Жизнь преподобной матери нашей Марии Египетской»: (Сост. по руководству Четьи-Минеи): (Для нар. чтения). Москва: Манухин, 1872; «Жизнь преподобной матери нашей Марии Египетской»: Сост. по руководству Четьи-Минеи. Для народного чтения. Москва: Абрамовы, 1874; «Жизнь преподобной Марии Египетской»: заимствована из разных источников, указанных здесь в прибавлениях, с ближайшим применением к сказанию св. Софрония, патриарха Иерусалимского об этой преподобной». Санкт-Петербург, Москва: Тип. Глушкова, 1860; «Жизнь преподобной матери нашей Марии Египетской». Москва: Шарапов, 1879; «Святая Мария Египетская: повесть о ее дивной жизни и великих подвигах. Молитвы, поста и покаяния» / сост. С. П. Извольский. Москва: Тип. М. П. Погодина, 1871.

4 См. [Тарасова, 2015: 7]. 
рассказом о жизни Святой Марии, которую Достоевский в «Набросках и планах неосуществлённых произведений» кратко характеризует так: «Пустынник - Мария Египетская» [Достоевский. Т. 12: 6]. Немногие из подвижников удостоены особой чести поминовения во время Великого поста. И среди них только одна женщина - преподобная Мария. Это объясняет запись Достоевского.

Необычная жизнь египетской пустынницы производит впечатление и на Аркадия, главного героя романа «Подросток». О ней он узнал из рассказа Макара Ивановича, который любил легенды и истории из жизни раннехристианских подвижников. Эти рассказы, как свидетельствует сам Достоевский в «Дневнике писателя» за 1877 г., глубоко впечатляли тех, кто их слушал ${ }^{1}$. Странник Макар Иванович принадлежал к числу умелых повествователей, как свидетельствует Аркадий: «Об житии этом, да почти и об всех подобных, я не имел до того времени никакого понятия. Я прямо говорю: это почти нельзя было вынести без слов, и не от умиления, а от какого-то странного восторга: чувствовалось что-то необычайное и горячее, как та раскаленная песчаная степь со львами, в которой скиталась святая». [Достоевский. Т. 13: 382]. Интересно, что упоминания о львах нет в жизнеописании Марии Египетской, включённом в «Избранные жития святых». Но оно есть в житии святителя Димитрия Ростовского, так же, как и в рассказе Софрония, патриарха Иерусалимского, который пишет, что могилу преподобной Марии выкопал лев ${ }^{2}$.

Это не единственное упоминание о Марии Египетской в «Подростке». В одном из вариантов романа есть следующее примечание: «Золотой век. Макар и Мария Египетская». Возникает естественный вопрос: что связывает Марию Египетскую, Макара и выражение «Золотой век», фигурирующее в названии рассказа «Золотой век в кармане» [Достоевский. Т. 22: 12-13]. ${ }^{3}$ В этом совсем коротком произведении автор

1 «В этих рассказах, и в рассказах про святые места, заключается для русского народа, так сказать, нечто покаянное и очистительное» [Достоевский. Т. 25: 215]

2 Кроме других элементов, деталь о льве является признаком того, что Софроний знал житие Павла Фивейского и использовал его в качестве образца в составлении «Жития преподобной матери нашей Марии Египетской» [Delmas: 39]. В житии Павла Фивейского рассказывается о том, что преподобный Антоний с помощью двух львов выкопал преподобному Павлу могилу.

3 Рассказ «Золотой век в кармане» включён Достоевским в «Дневник пи- 
размышляет о том, как изменилась бы жизнь отдельного человека, а с ней и жизнь общества, если люди смогли бы «на миг один, стать искренними и простодушными». Любовь к истине на самом деле является чертой, которая объединяет Макара Ивановича, героя романа «Подросток», известного своими назидательными рассказами, и Марию Египетскую. Искренне признав свои грехи перед лицом Бога, эта женщина, погрязшая в пороке, смогла резко изменить свою жизнь.

Из анализа упомянутых произведений мы видим, что Достоевский с Марией Египетской сопоставляет некоторых раскаявшихся великих грешников. Речь идет о Родионе Раскольникове и Дмитрии Карамазове. Пример Преподобной Марии Египетской напоминает читателю, что кардинальное изменение жизни требует большого подвига. Но этот подвиг является единственным путем для восстановления образа Божьего внутри героя.

Тема преображения и духовного возрождения человека является одной из центральных во всем творчестве Достоевского, начиная с «Бедных людей» и заканчивая последним романом «Братья Карамазовы» [Захаров, 2010: 22]. Для писателя это больше, чем просто тема, это «творческая задача», которую Достоевский раскрывает в письме от 15 июня 1880 г. Юлии Фёдоровне Абаза, ${ }^{1}$ обратившейся к нему с просьбой прочитать и оценить её рассказ. Великий писатель оценил рассказ отрицательно, но критикой он не ограничился, а дал совет, который можно назвать квинтэссенцией его поэтики: художественный метод неотделим от содержания произведения. О главном герое рассказа Юлии Фёдоровны Достоевский говорит: «У Вас та же идея. Но Ваш потомок ужасного и греховного рода изображен невозможно. Надо было дать ему страдание лишь нравственное» [Достоевский. Т. 30-1: 192]. Закончить рассказ Достоевский предлагал следующим образом: «...сделав из него кого-нибудь в образе Алексея человека божия или Марии Египетской, победившей кровь свою и род свой страданием неслыханным». Эта последняя мысль перекликается с заключением жития Марии Египетской в сборнике «Избранные жития святых», где написано: «Тяжелая борьба грешницы с дурными наклонностями и страстями должна и нас укрепить в той вну-

сателя» (Январь, 1876 г.).

1 Юлия Фёдоровна Абаза (урождённая Штуббе) - писательница, певица и композитор, жена А. А. Абаза, министра финансов Российской Империи 1880 гг. 
тренней борьбе со злом, которая невидимо происходит в душе каждого. Если и мы выйдем из нее победителями, если и нам удастся одолеть в душе нашей порочные склонности и удалить искушения плоти нашей, то этим духовным подвигом мы так же верно угодим Богу, как угодила ему святая Мария Египетская глубоким раскаянием и трудною жизнью в пустыне» [Избранные жития святых: 15-16].

Изучение тех фрагментов произведений Достоевского, в которых упоминается образ преподобной Марии Египетской, показывает основополагающую цель новозаветных и патристических отсылок: человеку дана божественная милость подняться, возродиться. Как мы постарались показать, наиболее заметна связь между жизнеописанием Марии Египетской из сборника «Избранные жития святых» и «Житием Марии Египетской» Димитрия Ростовского, которое, в свою очередь, довольно верно повторяет рассказ о жизни преподобной патриарха Софрония Иерусалимского ${ }^{1}$. Тексты о преподобной Марии Египетской, пронизанные христианской верой и мудростью святых отцов, как в подлиннике, так в последующих обработках, имеющих и литургическое употребление, безусловно стали источником вдохновения Достоевского.

\section{Список литературы}

Альтман М. С. Использование многозначности слов и выражений в произведениях Достоевского // Учёные записки Тульского государственного педагогического института. 1958. Вып. 11. С. 3-41.

Библиотека Ф. М. Достоевского. Опыт реконструкции / Рос. акад. наук, Ин-т рус. лит. (Пушкин. Дом); [сост. Н. Ф. Буданова и др.]. СПб: Наука, 2005. 336 с.

Григорьев Д. Достоевский и церковь: у истоков религиозных убеждений писателя. М.: Православный Свято-Тихоновский Богословский институт, 2002. 175 с.

Достоевский Ф. М. Полн. собр. соч.: в 30 т. Л.: Наука, 1972-1990.

Захаров В. Н. Фантастические страницы Достоевского // Проблемы исторической поэтики. 2008. № 8. С. 385-398.

Захаров В. Н. Достоевский и Евангелие // «Евангелие» Достоевского. Исследования. Материалы к комментарию: в 2 т. Т. 2. Москва: Русский мир, 2010. С. 5-35.

Избранные жития святых, кратко изложенные по руководству Четьих-Миней. Апрель. Москва: Тип. Бахметева, 1864.

Опульская Л. Д. История создания романа // Достоевский Ф. М. Преступление и наказание / под ред. Л. Д. Опульской и Г. Ф. Коган. М.: Наука. С. 681-715.

\footnotetext{
1 Текст «Житие преподобной матери нашей Марии Египетской» Димитрия Ростовского корректно воспроизводит одноимённое жизнеописание, сделанное Святым Софронием, патриархом Иерусалимским, отличаясь от него только более кратким изложением.
} 
Тарасова Н. А. Христианская тема в романе «Преступление и наказание» Ф. М. Достоевского: Проблемы изучения. М.: Квадрига, 2015. 190 с.

Тарасова Н. А. Проблемы интерпретации сюжета «Преступление и наказание» Ф. М. Достоевского в текстологическом аспекте // Mundo Eslavo revista de cultura y estudios eslavos. 2017. Vol. 16. P. 273-282.

Cavazza A. "Vinci te stesso e vincerai il mondo". Le fonti di un aforisma ricorrente nelle opere di Dostoevskij dell'ultimo periodo // Il mondo slavo e l'Europa, Fupress. Firenze, 2019. P. 127-136.

Delmas F. Remarques sur la vie de sainte Marie l'Egyptienne. Echos d'Orient. 1901. Vol. 4. P. 35-42.

\section{References}

Al'tman M. S. Ispol'zovanie mnogoznachnosti slov $i$ vyrazhenii v proizvedeniiakh Dostoevskogo [Using the polysemy of words and expressions in the works of Dostoevsky]. Uchenye zapiski Tul'skogo gosudarstvennogo pedagogicheskogo instituta [Scientific notes of the Tula State Pedagogical Institute]. 1958. Vol. 11. P. 3-41. (In Russ.)

Biblioteka F. M. Dostoevskogo. Opyt rekonstruktsii [The library of F. M. Dostoevsky. Reconstruction Experience]. Ros. akad. nauk, In-t rus. lit. (Pushkin. Dom). St. Petersburg: Nauka Publ, 2005. 336 p. (In Russ.)

Grigor'ev D. Dostoevskii $i$ tserkov': $u$ istokov religioznykh ubezhdenii pisatelia [Dostoevsky and the Church: at the origins of the writer's religious beliefs]. Moscow: Pravoslavnyi Sviato-Tikhonovskii Bogoslovskii institute Publ, 2002. 175 p.

Dostoevskii F. M. Poln. sobr. soch.: v 30 t. [Full Sobr. Op.: 30 vols.] Leningrad: Nauka Publ, 1972-1990. (In Russ.)

Zakharov V. N. Fantasticheskie stranitsy Dostoevskogo [Fantastic pages of Dostoevsky]. Problemy istoricheskoi poetiki [Problems of historical poetics]. 2008. Vol. 8. P. 385-398. (In Russ.)

Zakharov V. N. Dostoevskii i Evangelie [Dostoevsky and the Gospel]. "Evangelie" Dostoevskogo. Issledovaniia. Materialy k kommentariiu: $v 2$ t. T. 2. ["The Gospel” of Dostoevsky. Research. Commentary in 2 vols. Vol. 2]. Moscow, Russkii mir Publ, 2010. P. 5-35. (In Russ.)

Izbrannye zhitiia sviatykh, kratko izlozhennye po rukovodstvu Chet'ikh-Minei. Aprel' [Selected lives of the saints, summarized according to the guidance of the Fours-Mineas. April]. Moscow, Tip. Bakhmeteva Publ, 1864. (In Russ.)

Opul'skaia L. D. Istoriia sozdaniia romana [The story of the creation of the novel] Dostoevskii F. M. Prestuplenie $i$ nakazanie pod red. L. D. Opul'skoi i G. F. Kogan. [Dostoevsky F. M. Crime and Punishment] Moscow: Nauka Publ. P. 681-715. (In Russ.)

Tarasova N. A. Khristianskaia tema $v$ romane "Prestuplenie i nakazanie" F. M. Dostoevskogo: Problemy izucheniia [The Christian theme in the novel Crime and Punishment by F. M. Dostoevsky: Problems of Study]. Moscow, Kvadriga Publ, 2015. 190 p. (In Russ.)

Tarasova N. A. Problemy interpretatsii siuzheta "Prestuplenie i nakazanie" F. M. Dostoevskogo v tekstologicheskom aspekte [Problems of interpretation of the plot "Crime and Punishment" by F. M. Dostoevsky in the textual aspect]. Mundo Eslavo revista de cultura y estudios eslavos. 2017. Vol. 16. P. 273-282. (In Russ.)

Delmas F. Remarques sur la vie de sainte Marie l'Egyptienne. Echos d'Orient. 1901. Vol. 4. P. 35-42. (In French) 


\section{Slavic research group at the University of Ottawa}

Abstract: The article describes the creation of a Slavic research group at the University of Ottawa and its activities. The main task of the group when it was created was to unite a number of scholars in order to master and better understand the world of Slavic literature and culture. One of the tasks of the Slavic research group was the study of Russian and Polish languages, which are taught to students of the University of Ottawa. The article describes the composition of the group, its gradually expanding activities, including it's today cooperation with a number of leading scientific organizations of the world, active publishing and search work aimed at clarifying data on Russian and Polish literature, archival research, lectures, conferences, exhibitions and festivals.

Keywords: Slavic research group, Russian culture, Polish culture, University of Ottawa, international cooperation, academic centers, Russian literature

Information about the author: Andrew A. Donskov, DSc in Philology, Professor, Slavic research group at the university of Ottawa, Ottawa, Canada

E-mail: adonskov@uottawa.ca

Received: September 03, 2019

Published: December 10, 2019

For citation: Donskov A. A. Slavic research group at the University of Ottawa. Two centuries of the Russian classics, 2019, vol. 1, № 2, pp. 186-195. (In Russ.) DOI 10.22455/26867494-2019-1-2-186-195 


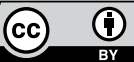

This is an open access article distributed under the Creative

Commons Attribution 4.0

International (CC BY 4.0)

(C) 2019. А. А. Донсков

г. Оттава, Канада

\section{Славянская исследовательская группа в университете г. Оттава}

Аннотация: В статье рассказывается о возникновении Славянской исследовательской группы в университете г. Оттавы и ее деятельности. Основной задачей создания группы было объединение ряда ученых с целью освоения и лучшего понимания мира славянской литературы и культуры, изучения русского и польского языков, которые преподаются студентам университета Оттавы. В статье рассказывается о составе группы, о ее постепенно расширяющейся деятельности. Сегодня Славянская исследовательская группа сотрудничает с рядом ведущих научных организаций мира, ведет активную издательскую и поисковую работу, направленную на уточнение данных о русской и польской литературе, архивные разыскания, проводит лекции, конференции, выставки и фестивали.

Ключевые слова: Славянская исследовательская группа, русская культура, польская культура, университет г. Оттавы, международное сотрудничество, академические центры, русская литература

Информация об авторе: Донсков Андрей Александрович, доктор филологических наук (PhD), профессор, Славянская исследовательская группа при университете Оттавы, г. Оттава, Канада

E-mail: adonskov@uottawa.ca

Дата поступления статьи в редакцию: 03.09 .2008

Дата публикации статьи: 10.12.2019

Для иитирования: Донсков А. А. Славянская исследовательская группа в университете г. Оттава // Два века русской классики. 2019. Т. 1. № 2. С. 186-195. DOI 10.22455/2686-7494-2019-1-2-186-195 
The Slavic Research Group (SRG) at the University of Ottawa was created in 1998 as an interdisciplinary centre for research and publication on Slavic themes. It has brought together a number of scholars from diverse disciplines (notably language, linguistics, history and literature, as well as Canadian studies), from diverse branches of Slavdom (especially Russian, Polish and Serbian), and from diverse geographical locations (Ottawa, Toronto, Victoria, Montréal, Lublin, St-Petersburg, Moscow, Yasnaya Polyana) - all to contribute to a better world understanding of Slavic literature and culture. To date, our principal focus has been in the areas of Russian and Polish - the two major Slavic disciplines offered by the Department of Modern Languages\& Literatures at the University of Ottawa - from a Canadian perspective.

The SRG's mandate is to complement and enhance the work of individual departments at the University of Ottawa in undertaking and publishing research on Slavic cultural and literary themes, organising and publishing the proceedings of academic symposia, sponsoring lectures and other cultural events for both academic and local communities, initiating and renewing international contacts with like-minded institutions abroad, and translating documents between Slavic languages and Canada's official languages. Our first twenty years have seen activity in nearly all these areas.

Our Slavic Research Group, whose activities are overseen by the Associate Dean of the Faculty of Arts, comprises faculty members from various departments at the University of Ottawa, as well as external scholars and researchers from other universities and institutions both in Canada and abroad (a list of current members is appended below). Among our distinguished honorary members from Russia have been Lidija Gromova, Galina Galagan, Marina Shcherbakova, Galina Alekseeva and Ljudmila Gladkova. The current SRG Director is Dr Richard Sokoloski, Professor of Polish at the University of Ottawa (see appendix below for a complete list of current members).

Since its inception, a major focus for the SRG has been cultivating ties with prominent academic institutions in the Slavic-speaking world (specifi- 
cally in Poland and Russia). In Poland we signed memoranda of agreement with the Polish Academy of Arts \& Sciences, the Catholic University of Lublin and the Jagiellonian University in Kraków. In Russia, we have formal ties with the Russian Academy of Sciences (in particlar, its Institute of World Literature in Moscow and its Institute of Russian Literature ((Pushkinskij Dom) in St-Petersburg), the Tolstoy Museums in Moscow and Yasnaya Polyana, the Moscow State Institute of International Relataions (MGIMO) and the Canada College at the University of St-Petersburg. Within Canada we have co-operated with the Centre for Research on Canadian-Russian Relations (CRCRR, currently based at Georgian Collegee in Barrie, Ont.), headed by J. Larry Black, also the University of Toronto's Centre for Russian and East European Studies (CREES) and the Institute of Canadian Studies (ICS) at the University of Ottawa.

This collaboration has resulted in more than thirty books published to date, which have collectively engendered a significant number of favourable reviews by prominent Slavic scholars (including Hugh McLean, Irina Paperno, Gary Jahn and Donna Orwin). The overall response has more than justified our decision to base the bulk of our publishing output on archival sources, with research and documentation by leading specialists in their fields, enhancing their value to world scholarship.

A few examples: (a) the three volumes in our Polish Translation Series, published jointly with Towarzystwo Naukowe Katolickiego Uniwersytetu Lubielskiego in Lublin; (b) The unity of peoples in Leo Tolstoy's works, co-published by the Russian Academy of Sciences in Moscow and St-Petersburg; (c) other volumes in our Tolstoy Series, published in conjunction with the State L.N. Tolstoy Museum in Moscow.

Notable in this latter category is a two-volume publication comprising some 1,150 pages entitled: L. N. Tolstoj i N. N. Strakhov: polnoe sobranie perepiski / L. N. Tolstoy and N. N. Strakhov: complete correspondence, ed. A. Donskov, making available for the first time in its entirety the full integrated exchange of letters between Leo Tolstoy and his friend and editorial associate Nikolaj Strakhov. It offers its readers a unique insight into the minds of two great $19^{\text {th }}$ century Russian thinkers as they engage in earnest dialogue on a wide spectrum of religious, philosophical, social and literary questions. The letters are complemented by the editor's introductory essay (in English) and extensive annotations (many drawn from archival sources) prepared by two leading Tolstoy scholars in Moscow: the late Dr Lidija Gromova, who 
was Head of Classical Literature at the Russian Academy of Sciences' Institute of World Literature, and Tat'jana Nikiforova of the State L .N. Tolstoy Museum in Moscow.

These volumes are a sine qua non for any future research into either Tolstoy's or Strakhov's views on life and literature (Strakhov was indeed a philosopher in his own right), or into the nature of their unique personal relationship. Tolstoy often consulted with Strakhov in developing his own literary ideas, and let himself be guided by the latter's highly valued input. The concluding pages of Volume II contain a summary chronological listing of all the letters as well as two indexes (one of Tolstoy's works and the other of personal names).

This publication met with a most enthusiastic reception on the part of Tolstoy specialists. Witness, for example, the following excerpts from a roundtable discussion of the Tolstoy-Strakhov correspondence held on 22 February 2006 at the Institute of World Literature of the Russian Academy of Sciences in Moscow, later published in Tolstoy Studies Journal (XVIII, 2006: 89-95) in Donna Orwin's English translation.

From P. V. Palievskij: "For the first time, we have a completely restored picture of Tolstoy's communication with a contemporary with whom he was completely open, with whom he expected to find and found understanding, and with a man who was indisputably distinguished in his own right. <...> Now we have this book. The comprehensive foreword by A. A. Donskov, unfortunately only in English, explains how it came into being and how invaluable material was retrieved from the archives of Kiev, Pushkin House, and other repositories. It also outlines the entire history of the relationship between Strakhov and Tolstoy. Most importantly, the book enables ideas to speak again, ideas without which, it turns out, we cannot manage today. We extend our thanks to the editors, commentators, and publishers who have brought these ideas back into our lives."

From A. V. Gulin (Editor-in-Chief, Polnoe sobranie sochinenij L. N. Tolstogo): "The publication of the correspondence between Strakhov and Tolstoy is, without question, an extraordinary event. In its intensiveness, intellectual variety, candor of expression, and finally, its duration in time, this correspondence is an exceptional occurrence in Tolstoy's epistolary legacy. <...> Published for the first time as an integrated whole, the correspondence between Tolstoy and Strakhov appears as a monument, a monolith. And it is an amazing monument, both artistically and historically. We have here the 
history of two Russian fates in a critical epoch of Russian history. Tolstoy's famous letters and Strakhov's widely known letters will naturally now be read anew, in the general context of the bilateral correspondence. We are now able to penetrate into its rich, private subject matter and grasp it in one view, to understand how such personages relate to one another, to see them during their development over many years. Everything in this correspondence is fascinating...”

From G. Ja. Galagan (Pushkin House, Russian Academy of Sciences): "The Canadian publication has already played two important roles. First, it clarifies issues in the relationship between Strakhov and Dostoevsky, including biographical details and the circumstances of the final stage of Strakhov's work on the biography of Dostoevsky and his unexpected outburst of hatred. Second, it helps reveal Strakhov's duality as the dominant feature of his emotional life. These new materials helped V. A. Tunimanov show previously unseen but now self-evident material."

Two years later, under "News of the profession" in Vol. XX of the Tolstoy Studies Journal (2008: 112-113) Prof. Donna Orwin of the University of Toronto wrote that the Slavic Research Group's "achievements in the area of Tolstoy studies are remarkable". She continued: "After the fall of the Soviet regime, founder and director Professor Andrew Donskov saw an opportunity to work with Russian colleagues. His chief Russian collaborator, L. D. Gromova-Opul'skaia, at the Institute of World Literature at the Academy of Sciences in Moscow - among her other accomplishments, the world's foremost Tolstoy textologist - agreed, and the two began a collaboration truly in the spirit of Tolstoy an universal brotherhood. Over a period of fifteen years, until Gromova-Opul'kaia's untimely death in 2003, they headed a team of Russian scholars who prepared one volume after another of unpublished Tolstoy materials. These were almost all published through the SRG (jointly with either the Russian Academy of Sciences or the Tolstoy Museum in Moscow), some of them with parallel English translations by John Woodsworth and critical introductions in English by Professor Donskov - and all this apart from Donskov's own monographs on Tolstoy. <...> Every one of the Group's publications is valuable, all are prepared with high standards of scholarship, and not one would exist without the vision and hard work of Professor Donskov and his team."

To mark the occasion of the fifteenth anniversary of the Slavic Research Group (2013), the Tolstoy Studies Journal's Volume XXIV (2012, pp. 122- 
130) devoted a 9-page review to SRG activities and publications, saying its "achievements are truly remarkable, and its contribution to Tolstoy studies, to the Slavic field, and, what is more, to literary studies generally, is enormous". Moreover, this review essay was penned by two world-renowned Slavic scholars: Irina Paperno and Professor Emeritus Hugh McLean. Here are a few brief excerpts: "In fifteen years, a small group of dedicated scholars, headed by Professor Andrew Donskov of the University of Ottawa (the Group's founder and Director), has published a large number of carefully selected and meticulously prepared documents from the vast heritage of Lev Tolstoy, his family, and his circle. <...> It would not be possible to speak of all of these editions, each outstanding in judicious choice of the material, meticulous preparation, and incisive, but unintrusive, commentary. Some, however, clearly stand out.

Especially noteworthy is the monumental edition of Tolstoy's complete correspondence with Nikolai Strakhov, one of the most important documents of Tolstoy's life and thought. In the words of Andrew Donskov, 'the germ of almost all the moral/religious principles [Tolstoy] expounded in the last three decades of his life can be found in his pre-1880 letters to Strakhov.'

It was hard for us to imagine that, with all that has been published over the years by generations of scholars and faithful followers, new material could be uncovered. But we were proven wrong. <...> Many of the Group's editions are a product of joint efforts by the [University] of Ottawa and the Tolstoy Museum in Moscow, as well as the Institute of Russian Literature (Russian Academy of Sciences, St. Petersburg) and the Institute of World Literature (Russian Academy of Sciences, Moscow). Such collaboration offers a remarkable example of what can be achieved in an equal partnership with Russian academic institutions. These editions manifest a degree of friendly cooperation between Russian and Canadian scholars that would have been quite impossible in the Soviet times. Many of the Ottawa Group's publications are bilingual. With this, the Canadian scholars have opened still unexplored, or long neglected, sources to a double audience of English- and Russian-speaking Tolstoy lovers, and to others around the word. In this and other senses, these editions are in themselves a form of dialogue that is worthy of the publishing ventures of the Tolstoy circle.

When Donna Orwin wrote about the Ottawa Group's remarkable contributions in the Tolstoy Studies Journal in 2008, on the tenth anniversary of the Group, she described this as cooperation 'truly in the spirit of Tolstoyan 
universal brotherhood.'Such moments of 'brotherhood' are rare even in the academic community, and it is on this account, too, that these joint publications have won the admiration and gratitude of scholars around the world."

It is not an exaggeration to say that our other joint publications have received, collectively, dozens of equally favourable reviews, and won international acclaim and awards.

For example, Sergej Tolstoy and the Doukhobors: a journey to Canada was published in collaboration with the L. N. Tolstoy Museum in Moscow; the Museum's own Tat'jana Nikiforova was not only the chief compiler but also contributed one of the introductory essays; it garnered laudatory reviews in a number of prominent journals, including the Russian Language Journal, The Slavonic \& East Europen Review, the Slavic \& East European Journal and Revue des Etudes slaves. It was later re-issued with my introduction in a Russian translation by Kuchkovo Pole Publishers in Russia.

L.N. Tolstoy i F. A. Zheltov: Perepiska was also published jointly with the Tolstoy Museum; it was reviewed in Russkaja literatura, Germano-Slavica, Slavonica and The Social Science Journal, among others. It was later republished by Ethel Dunn at the Highgate Road Social Science Research Station in California (in conjunction with the SRG) in an English translation by John Woodsworth (A Molokan's search for truth: the correspondence of Leo Tolstoy and Fedor Zheltov) and reviewed additionally in the Tolstoy Studies Journal,Canadian Slavonic Papers and Modern Language Review.

Another joint publication, this time with IMLI, was Marina Shcherbakova's volume Ivan Aksakov - Nikolaj Strakhov: Correspondence, which was also highly acclaimed in the Western press.

In more recent years the Slavic Research Group has entered into co-operative ventures with the University of Ottawa Press. Three of its members played a distinctive role in the publication of two landmark volumes regarding Sofia Andreevna Tolstaya (Leo Tolstoy's wife of 47 years) - Andrew Donskov as editor with John Woodsworth and Arkadi Klioutchanski as co-translators. In 2010 the Press released Tolstaya's extensive autobiographical memoir My life, a mammoth 1240-page volume including a 64-page section of colour illustrations, a selected genealogy, a critical editorial essay, a bilingual poetry appendix, a chapter outline, a footnote index and an index of Tolstoy titles. The second book comprised a selection of some 250 letters (out of approximately 1,500 the couple exchanged over their lifetime) and included - in addition to most of the features mentioned for the first 
book - a Foreword by Vladimir Il'ich Tolstoy, a translators' note, a selected chronology and a list of periodical titles. Contributing to this second major volume was a third co-translator, Ljudmila Gladkova, Senior Researcher and Deputy Director of the Moscow Tolstoy Museum, with her comprehensive knowledge of both Tolstoy and his family, especially Sofia Andreevna.

Over the years we at the Slavic Research Group have been most grateful for the collaboration with our colleagues in Slavic-speaking countries. In addition to those already mentioned, we may cite in particular (in alphabetical order): Sergej Arkhangelov, Valentina Bastrykina, Tat'jana Gorjaeva, Zinaida Ivanova, Natal'ja Kalinina, Tat'jana Komarova, Feliks Kuznetsov, Vadim Polonskij, Vitalij Remizov.

Two of our Russian contributors have been accorded special recognition: The late Dr Lidija Gromova-Opul'skaja received a citation engraved on a plaque, while Dr Marina Shcherbakova was awarded a medal struck on the occasion of the 150th anniversary of the University of Ottawa.

The SRG also collaborated with the CRCRR (originally based at Carleton University in Ottawa) in producing the Canada/Russia Series, under the general editorship of J. Larry Black and Andrew Donskov. The first volume in this series was Russian roots \& Canadian wings: Russian archival documents on the Doukhobor emigration to Canada - compiled, translated and annotated by the SRG's John Woodsworth, who has done a number of translations for SRG publications. The seventh volume in the series was a monograph by Andrew Donskov: Leo Tolstoy and the Canadian Doukhobors: an historic relationship - soon to be republished in a new, enlarged edition by the University of Ottawa Press.

In addition to actual research and publication, our activities also include hosting conferences, lectures, cultural events and exhibits, film festivals, etc. - many of them in co-operation with the embassies of Slavic-speaking countries here in our nation's capital, and many open to the public at large. For example, the SRG worked with the Russian Embassy to mount two exhibit of the Russian artist Igor' Soldatenkov. In 2003 the then Yugoslav ambassador Dr Miodrag Perišić gave a talk on "Story-telling and the perception of history", while a month later his wife, Žaneta Djukić-Perišić spoke on the role of Yugoslav novelist Ivo Andrić in bridging the East-West gap in South Slavic literature. A number of addresses on Canada-Russia cultural relations have been given to large audiences under SRG auspices at the University of Ottawa by successive Russian ambassadors, notably Vitalij Churkin, Georgij 
Mamedov and Aleksandr Darchiev. We have also hosted talks and initiatives by Polish ambassadors, namely: Bogdan Grzeloński, Paweł Dobrowolski, Zenon Kosiniak-Kamysz, Piotr Ogrodziński and Andrzej Kurnicki.

One of the SRG's aims has been to highlight cultural associations between Slavic peoples and Canada. A major contribution along this line was the hosting (in October 1999) of a major international conference on The Doukhobor centenary in Canada - an historical retrospective on the religious sect known as the Doukhobors, whose persecution-fleeing emigration to Canada in 1899 was financed by Leo Tolstoy himself. He had discovered in their life-style an embodiment of his own philosophical ideas on finding God in individual hearts instead of church hierarchies and a shared rejection of militarism and conscription. Some thirty thousand descendants of these emigrants (many of whom still maintain a knowledge of Russian) make their home in western Canada today, especially Saskatchewan and British Columbia. Conference speakers came from Russia, Britain, the USA and Canada, including scholars from the Doukhobor community itself. The SRG published the Proceedings the following year in collaboration with the Institute of Canadian Studies at the University of Ottawa.

We are grateful for all the support the SRG has received from the university, diplomatic and public communities, as well as for our collaboration with both individual scholars and academic institutions in Canada and abroad. With this support we are encouraged to continue our global outreach through research, publication and cultural activities in the years to come. 


\title{
Текстологические сюжеты русской классики: актуальные решения ${ }^{1}$
}

\begin{abstract}
Аннотация: Статья представляет собой рецензию на коллективный труд, изданный в ИМЛИ РАН и посвященный актуальным вопросам текстологии. Автор статьи кратко обозревает основное содержание издания в целом и каждой работы в частности, акцентируя внимание на открытиях ученых-текстологов: изучении поэтического наследия М. Н. Муравьева; уточнении датировки и посвящений отдельных стихотворений А. С. Пушкина; освещении формы и философского содержания стихотворений М. Ю. Лермонтова; публикации полного текста ранней редакции повести Н. В. Гоголя «Вий»; истории находки и издания второго тома «Мертвых душ»; творческой истории некоторых произведений И. С. Аксакова, Н. С. Лескова; изучении отдельных сцен и тем романа Л. Н. Толстого «Анна Каренина» с учетом рукописных материалов. Самостоятельное внимание в коллективном труде посвящено литературоведческой и текстологической работе Л. Д. Громовой-Опульской, выдающегося ученого XX в. Ученики Л. Д. Громовой-Опульской представляют обзор ее замыслов, методику работы, иллюстрируя примерами, позволяющими оценить труд большого ученого.

Ключевые слова: русская классическая литература, текстология, литературный процесс, история текста, история изданий, авторская воля, варианты, редакции, автографы, архивные материалы
\end{abstract}

Информация об авторе: Андреева Валерия Геннадьевна, ORCID 0000-00024558-3153, доктор филологических наук, ведущий научный сотрудник, Институт мировой литературы им. А. М. Горького Российской академии наук, ул. Поварская, д. 25a, 121069, г. Москва, Россия

E-mail: lanfra87@mail.ru

Дата поступления: 05.11.2019

Дата публикации: 10.12 .2019

Для иитирования: Андреева В. Г. Текстологические сюжеты русской классики: актуальные решения // Два века русской классики. 2019. Т. 1. № 2. С. 196-208.

DOI 10.22455/2686-7494-2019-1-2-196-208

1 Рецензия на коллективный труд: От истории текста к истории литературы. Вып. 2. М.: ИМЛИ, 2019. 592 с. 




This is an open access article distributed under the Creative

Commons Attribution 4.0

International (CC BY 4.0)

(c) 2019. Valeria G. Andreeva

Moscow, Russia

\title{
Textological subjects of Russian classics: actual solutions
}

\begin{abstract}
The article presents a review of the collective work published at IMLI RAS and devoted to a number of textual problems. The author briefly observes the main content of the publication in general and of each work in particular, focusing on the discoveries of textual scholars: studying the poetic heritage of M. N. Muravyov, specifying the dating and dedications of a number of A. S. Pushkin 's poems, highlighting the form and philosophical content of M. Yu. Lermontov's poems, the publication of the full text of the early version of the novel by N. V. Gogol "Viy", the history of the find and publication of the second tome of "Dead Souls", the creative history of a number of works by I. S. Aksakov, N. S. Leskov, the study of separated scenes and themes of the novel by L. N. Tolstoy "Anna Karenina" considering handwritten materials. Particular attention in collective work is given to the story of the literary and textual work of L. D. Gromova-Opulskaya, an outstanding scientist of the 20th century. Colleagues of L. D. Gromova-Opulskaya present a number of her ideas, the methodology of work, show valuable examples to evaluate the work of an outstanding scientist.
\end{abstract}

Keywords: Russian classical literature, textology, literary process, text history, history of publications, author's will, options, editions, autographs, archival materials

Information about the author: Valeria G. Andreeva, ORCID 0000-0002-4558-3153, DSc in Philology, Leading Researcher, A.M. Gorky institute of World Literature of the Russian Academy of Sciences, Povarskaya 25a, 121069, Moscow, Russia

E-mail: lanfra87@mail.ru

Received: November 05, 2019

Published: December 10, 2019

For citation: Andreeva V. G. Textological subjects of Russian classics: actual solutions. Two centuries of the Russian classics, 2019, vdl,. № 2, pp. 196-208. (In Russ.) DOI 10.22455/2686-7494-2019-1-2-196-208 
В 2019 г. в Институте мировой литературы Российской академии наук вышел второй выпуск коллективного труда «От истории текста к истории литературы». В него вошли работы сотрудников Отдела русской классической литературы, а также статьи нескольких сторонних авторов - из Российской национальной библиотеки, музея-усадьбы Л. Н. Толстого, Института русской литературы (Пушкинского Дома) Российской академии наук, Московского педагогического государственного университета, Санкт-Петербургского государственного университета и др. Ответственный редактор издания - М. И. Щербакова, д.ф.н., профессор, заведующая Отделом русской классической литературы ИМЛИ РАН.

Коллективный труд посвящен текстологическим проблемам русской литературы XVIII-XIX вв., в нем рассмотрены актуальные вопросы творческой истории произведений и их частей, исследуется творческая работа автора с текстом, вносимые поправки, уточняется датировка. Это дает возможность по-новому прочитывать шедевры русской классики. Ценными материалами, изданными в коллективном труде, стали впервые публикуемые поэтические и прозаические произведения. Особое внимание уделяется процессу и итогам работы по созданию комментариев к подготавливаемым ныне томам ПСС Л. Н. Толстого и И. А. Гончарова, а также осмыслению текстологической работы одного из известных академических отечественных ученых XX в. Л. Д. Громовой-Опульской.

Каждая статья, включенная в рассматриваемое издание, представляет собой целостную разработку определенной проблемы, однако не ограничивается ею, выходя к тем глобальным жизненным обобщениям, которые были свойственны русской литературе в целом. В результате перед читателем предстает существенно дополненный и стереоскопический образ эпохи, в которой литература занимала одно из центральных мест. 
Статья А. Д. Ивинского вводит в научный оборот более 30 неизвестных стихотворений М. Н. Муравьева - поэта, чья творческая судьба складывалась непросто; широко известный среди современников, он фактически выпал из поля зрения литературоведов. А. Д. Ивинский констатирует, что изданные и снабженные комментарием произведения М. Н. Муравьева являются лишь небольшой частью творческого наследия поэта. Автор статьи обращается к документам ОР РГБ, долго не имевшим даже номеров и лишь недавно систематизированным. Учитывая работы своих предшественников, эпизодически обращавшихся к рукописям М. Н. Муравьева, А. Д. Ивинский анализирует «Записную книгу» поэта, выделяя в ее составе несколько пластов. Текст каждого стихотворения сопровождается в статье комментарием и ценными аналитическими замечаниями.

Работа В. М. Есипова посвящена уточнению датировки отдельных стихотворений А. С. Пушкина, описанию истории их возникновения, анализу опубликованного текста в сопоставлении с автографами. Автор обращается к текстологическим проблемам, возникшим при подготовке ПСС А. С. Пушкина. Изучение автографа стихотворения Пушкина «Поэту» дало основание В. М. Есипову сделать вывод, что текст следует отнести к болдинской осени 1830 г., и написан он не позднее 4 ноября. Особое внимание в статье уделяется изучению истории создания шестой главы романа «Евгений Онегин». Автор статьи восстанавливает последовательность работы Пушкина над пятой и шестой главами. Иллюстрируя разногласия, существующие в литературоведении по поводу датировки указанных глав, В. М. Есипов находит фактические подтверждения тому, что «работа над первой частью известного нам текста шестой главы начата не ранее 25 июля 1826 г.» [Есипов: 59]. Определяя начало работы поэта над шестой главой, ученый опирается на помету о смерти Амалии Ризнич, сделанную Пушкиным на автографе элегии «Под небом голубым страны своей родной...», а завершение работы над главой связывает с возвращением Пушкина в Москву, посланием Вяземскому, отправленным Пушкиным по пути в столицу, а также чтением в Москве в период с 19 декабря по 5 января двух глав своей поэмы.

Отдельного внимания заслуживает уточнение места эпиграммы на Гнедича в собрании сочинений Пушкина. В. М. Есипов красочно описывает, как эпиграмма, тщательно зачеркнутая Пушкиным «Крив был 
Гнедич поэт...», оказалась в начале XX в. расшифрована литературоведами и напечатана. Исследователь объясняет, почему же эпиграмма была тщательно замарана чернилами: «Эпиграмма действительно остроумная и смешная, но несправедливая. По-видимому, это как раз тот случай, про который говорится: ради красного словца не пожалеешь и родного отца. Именно поэтому она и была тщательно зачеркнута Пушкиным» [Есипов: 63]. При этом автор статьи недоумевает по поводу «вездесущего взгляда» исследователей, не просто прочитавших эпиграмму, но разместивших ее в собраниях сочинений Пушкина рядом с восторженным откликом Пушкина на перевод Гнедичем «Илиады» Гомера. В рассуждении об адресате стихотворения «На холмах Грузии лежит ночная мгла...» В. М. Есипов сопоставляет два противоположных взгляда: с одной стороны, П. Е. Щеголева, С. М. Бонди и, с другой стороны, Марии Павловны Султан-Шах, констатируя, что «сама Султан-Шах по каким-то причинам (сегодня нам неведомым) не нашла возможным столь явно подчеркнуть значение своего открытия в споре о стихотворении...» [Есипов: 69]. Автор подчеркивает убедительность доводов М. П. Султан-Шах, доказавшей, что стихотворение «На холмах Грузии лежит ночная мгла...» посвящено невесте Пушкина Наталье Гончаровой. Основательно и объемное исследование зачеркнутых строф в стихотворении Пушкина «С Гомером долго ты беседовал один...». В. М. Есипов опирается в нем на факты, сопоставляет мнения современников поэта, а также различных исследователей. Кроме того, автор полагается и на художественную интуицию.

Небольшая статья В. С. Фомичевой посвящена стихотворению Пушкина «Два чувства дивно близки нам...». Исследовательница доказывает, почему поэта не удовлетворила первая редакция стихотворения, приближенная к переводу Р. Саути, сделанного ранее Пушкиным. B. С. Фомичева подчеркивает, что в понятия, дорогие лирическому герою, вложены не просто явления культового ряда, но предметы, дорогие сердцу человека, связанные с его самосознанием, с его местом в мире.

О шедевре М. Ю. Лермонтова «Выхожу один я на дорогу» рассуждает в своей работе В. И. Коровин, представляющий последовательный, логичный и полный анализ стихотворения. Автор статьи движется от читательских впечатлений к глубинным пластам текста: от описания особой музыкальности, напевности, логической стройности произве- 
дения В. И. Коровин переходит к подробному анализу размера стихотворения, звукописи, повышениям и понижениям тона. Исследователь показывает безусловную связь между интонационно-мелодическим строем произведения и его содержанием: «Таким образом, напевность пронизывает интимно-философические размышления, которые поддерживаются в свою очередь образами раздумий, например, проходящим через весь текст мотивом сна» [Коровин: 94]. Ученый оценивает стихотворение с точки зрения содержания как «откровенное и глубоко личностное признание». Освещая полярные точки зрения Д. Е. Максимова и Ю. М. Лотмана, В. И. Коровин соглашается с последним и делает вывод о принадлежности шедевра Лермонтова к итоговым лирическим созданиям поэта. В статье представлен глубокий анализ значений различных лексем, а также философия Лермонтова и его восприятие мира, жизни и себя в мире. В стихотворении речь идет о космическом масштабе и соответствующих реалиях, но «в сравнении с величественным и торжественным покоем Вселенной мир поэта полон печали, вызванной отсутствием гармонии в себе...» [Коровин: 99]. Привлекают читательское внимание размышления автора о философии Лермонтова и ее сопоставлениях с пониманием жизни и места в ней человека Пушкиным, Гейне и Тютчевым, об обретении Лермонтовым «цельности двуединого мира»: «Чем безнадежнее мысль о совершенстве земли, тем сильнее жажда блаженства за ее пределами» [Коровин: 110].

Несомненную текстологическую ценность имеет автограф повести Н. В. Гоголя «Вий», подготовленный к публикации И. А. Виноградовым. Тексту автографа предшествует авторское предисловие с пояснениями, показывающее глобальную и скрупулезную работу, проведенную ученым.

Статья И. А. Зайцевой посвящена сцене вранья в «Ревизоре» Гоголя - «квинтэссенции хлестаковских фантазий», как пишет исследовательница. Автор работы представляет поэтапную историю создания пьесы, а также рассматривает решения очень сложной текстологической проблемы в научных изданиях, начиная с выбора и решений Н. С. Тихонравова и заканчивая текстологической работой А. Л. Слонимского. Наглядно расхождения в рассматриваемой сцене представлены И. А. Зайцевой в приложениях.

Тематически близка к вышеуказанной статье работа Е. Г. Падериной, посвященная анализу оборванных черновиков Гоголя, на которых 
представлены наброски «Женитьбы» и отрывок статьи «О движении журнальной литературы». Е. Г. Падерина представляет аналитические решения редакторов по отношению к данным черновикам.

В центре статьи Е. Е. Дмитриевой и А. С. Шолоховой - один из самых обсуждаемых вопросов в гоголеведении, касающийся судьбы рукописи и печатной истории второго тома «Мертвых душ» Гоголя. Исследователи поэтапно восстанавливают картину событий, происходящих после смерти писателя и касающихся описи его имущества, судьбы его текстов и документов.

Д. А. Бадалян представляет историю подготовки, публикации и корректуры книги И. С. Аксакова, посвященной Тютчеву - «Биография Федора Ивановича Тютчева». В статье доказывается, что концепция книги о знаменитом поэте сложилась у Аксакова не сразу, что сначала труд о Тютчеве должен был, по мысли Аксакова, представлять одну из биографий в общем ряду историй жизни близких Аксакову и интересных ему людей. Д. А. Бадалян анализирует отзывы на книгу супруги Тютчева и Ю. Ф. Самарина, а наиболее подробно останавливается на тех местах труда, которые вызвали недовольство и опасения цензуры. Д. А. Бадалян рассказывает, как в типографии был оставлен весь тираж номера «Русского архива» с публикацией статьи Аксакова. Автор анализирует замечания цензоров и сводит их к трем пунктам: «Во-первых, серьезное беспокойство вызвали суждения Аксакова от сути самодержавной власти. <...> Во-вторых, внимание цензуры привлекла проводимая Аксаковым, вслед за Хомяковым и Тютчевым, критика текущего положения власти. <...> В-третьих, не остались незамеченными критические суждения автора, адресованные самой цензуре, высказанные им по поводу заслуг Тютчева в деятельности на посту председателя Комитета цензуры иностранной» [Бадалян: 271-272]. А далее Д. А. Бадалян показывает, как переданная императрице Д. Ф. Тютчевой книга журнала со статьей Аксакова дошла до императора. И даже в целом положительная резолюция Александра II, разрешившего пропустить статью с исключением некоторых фраз, впоследствии загадочно отвергалась цензурой, странно пытавшейся ужесточить решение императора.

Статья А. Г. Гродецкой «Первый том писем академического ПССиП И. А. Гончарова» раскрывает историю подготовки к печати 15-го тома указанного издания, включающего письма Гончарова с 1842 г. по 1855 г. В работе кратко представлены основные вехи пути писателя в ука- 
занное время. А. Г. Гродецкая показывает, что сам Гончаров придавал письмам важную роль. Комментарии к письмам дают возможность исследователям устранить информационные пропуски в биографии и творческом пути Гончарова. Неподдельный интерес в статье вызывают сведения о персонах, знакомых Гончарову и упомянутых на станицах его писем. В работе даются их выразительные характеристики. Также раскрыты упоминания о лицах, благодаря которым, как показывает А. Г. Гродецкая, исследователями было основательно расширено представление о круге общения Гончарова в 1840-1850-е гг.

М. А. Мякинченко анализирует московскую тему в творчестве Ф. М. Достоевского. Автор обращается к биографическим истокам московских образов у писателя, показывает, какое место занимала Москва в общей идейно-философской системе Достоевского, какую роль сыграла в формировании его нравственно-этических воззрений. Статья содержит уникальные сведения о московском окружении писателя и впечатлениях, получивших отражение в мотивах творчества. Самым «московским» в наследии Достоевского М. А. Мякинченко справедливо считает роман «Подросток».

Работа В. В. Кашириной демонстрирует сходство и различие целей авторов, обращавшихся к одному и тому же эпизоду о златнице из «Сказания инока Парфения». Этот отрывок был использован в духовной литературе Оптиной пустыни, а также Ф. М. Достоевским в романе «Бесы». В. В. Каширина сопоставляет тексты и приходит к осознанию их внутреннего единства и различий, связанных с авторским замыслом и поэтическими приемами: в одном случае, эпизод представляет поучение, в другом используется в художественных целях.

Е. В. Белоусова анализирует повесть брата Л. Н. Толстого, Н. Н. Толстого под названием «Пластун». Автор показывает, что ее центральной темой стала ключевая для всего творчества Л. Н. Толстого мысль о самосовершенствовании, преодолении человеком испытаний, связанных в его жизни как с переменами внешнего характера, так и с душевными трансформациями. Исследовательница констатирует, что «задолго до того, как размышления о Боге и вечности зазвучали со страниц произведений Л. Н. Толстого, они стали лейтмотивом повести Н. Н. Толстого “Пластун” [Белоусова: 397]. Е. В. Белоусова анализирует сюжетно-композиционную структуру повести, ее основные мотивы и образ центрального героя - Запорожца, вспоминающего разные 
эпохи своей жизни, проводит параллели между идейно-тематическим содержанием повести «Пластун» и ключевыми центральными темами всего творчества Л. Н. Толстого.

Статья Е. В. Николаевой «Из творческой истории "Азбуки" Л. Н. Толстого (1871-1872)» примечательна реконструкцией и соотнесением различных перемен в семье Толстых и творческой деятельности Л. Н. Толстого в названный период. Автор анализирует ход работы писателя над «Азбукой», показывая, какое значение в этом процессе имела его педагогическая деятельность. К этому же времени, как пишет исследовательница, относится знакомство Толстого с Н. Н. Страховым и начало их переписки. Е. В. Николаева подмечает интересное совпадение, проявившееся в том, что обычно не очень откровенный с чужими людьми Толстой открыто писал еще малознакомому Страхову о собственном состоянии мучительного сомнения: «Удивительно, как точно в письме к незнакомому еще лично корреспонденту Толстой характеризует свое внутренне кризисное состояние, как бы предугадывая, что именно с этим корреспондентом будет очень скоро не только сотрудничать, но и детально делиться раздумьями о своем творчестве и состоянии современной литературы» [Николаева: 431].

Н. И. Романова обращается к истории подготовки и создания Толстым одной из самых ярких, психологически сложных и запоминающихся сцен романа «Анна Каренина» - сцены возвращения Анны из Москвы в Петербург. Исследовательница сопоставляет рукописи романа и выявляет движение творческой мысли Толстого. Особенно тонкие наблюдения Н. И. Романовой относятся к появляющимся в разных вариантах сценам художественным находкам, изменениям внутреннего мира и портрета героев. Исследовательница делает вывод, что в одной из рукописей романа намечается смысловой сдвиг, которым Толстой подчеркивает значимую для всего романа мысль: «Вронский ассоциируется у Анны с жизнью, радостью чувств; холодность, исходящая от Алексея Александровича, напротив, подавляет героиню, как бы замораживая и ее жизнь, и ее чувства» [Романова: 456].

А. Кавацца в статье «Тема смерти в романе Л. Н. Толстого "Анна Каренина”» представляет важные наблюдения относительно итогового текста произведения и конкретных языковых форм. Особое внимание в статье уделяется глаголам и глагольным формам в главе «Смерть», описывающим чувства и состояния Левина. 
И. И. Сизова обратилась к изучению творческого процесса художественной обработки Толстым старинной легенды о царе Аггее. Автор анализирует черновой автограф Толстого и реализацию темы наказания за гордыню; связывает творческий поиск художника с изменением его мировоззрения. Исследовательница предостерегает литературоведов от смешения черновых вариантов текста.

Статьи М. А. Можаровой и М. И. Щербаковой посвящены Л. Д. Громовой-Опульской, ее грандиозной литературоведческой работе и многочисленным замыслам, которые после смерти ученого продолжают осуществлять и воплощать в жизнь ее коллеги и ученики. М. А. Можарова обращается к проблеме изучения рукописей романа Толстого «Анна Каренина», рассказывает о роли в этом многотрудном деле Л. Д. Громовой-Опульской, останавливается на ее позиции относительно проблем и вопросов текстологии. В статье перечисляется множество открытий и заслуг Л. Д. Опульской, отдельно отмечаются ценные текстологические решения, предложенные в результате сопоставления текстов романа «Анна Каренина» изданий 1877 и 1878 гг. и рукописей Толстого. Все исправления, внесенные в текст романа Л. Д. Громовой-Опульской, предназначенные для публикации в 100-томном академическом Полном собрании сочинений Толстого, как показывает автор, были основаны на основательной, скрупулезной текстологической работе и глубоком понимании художественного текста.

Ход и методика работы большого ученого-литературоведа переданы в статье М. И. Щербаковой с очень значимым названием - «Служение гению». Это словосочетание, как рассказывает М. И. Щербакова, принадлежит Л. Д. Громовой-Опульской и выражает ее позицию и ее кредо: «Если текстолог любитель новаций, экспериментов и жаждет себя показать, то есть излишне самонадеян, успеха быть не может. Если текстолог понимает свою миссию как служение гению, все в порядке» [Щербакова: 504]. Автор статьи показывает, что непосредственно вслед за Н. Н. Гусевым Л. Д. Громова-Опульская продолжила титанический и капитальный труд - подготовку материалов к биографии Толстого. Со страниц статьи М. И. Щербаковой встает образ ученого-подвижника, исследовательницы, жившей своим делом и осознающей его глубинный смысл. Так, по замечаниям автора, Л. Д. Громова-Опульская за 50 лет работы подготовила тексты и прокомментировала научные издания многих русских классиков: А. И. Герцена, Ф. И. Тютчева, Ф. М. До- 
стоевского, А. П. Чехова, С. А. Есенина. Огромный опыт помогал ученому успешно проводить критику текста литературных шедевров и готовить их научные публикации. М. И. Щербакова подробно рассказывает об идее академического Полного собрания сочинений Толстого, о планах Л. Д. Громовой-Опульской, приводит примеры конкретной организации работы с отдельными томами, благодаря чему читатель может увидеть, как все у выдающегося текстолога было упорядочено, учтено, распределено, и что при этом все рабочие материалы находились под ее неустанным контролем. Представляя ряд интереснейших примеров уточнений и пояснений, исправлений, сделанных при изучении автографов Толстого, М. И. Щербакова показывает, какую важную, фундаментальную роль Громова-Опульская отводила исследованию сохранившегося рукописного фонда произведений.

А. А. Федотова в статье «Толстовский текст в повести Н. С. Лескова “Юдоль” п показывает линии пересечения Толстого и Лескова, влияния религиозно-нравственного учения первого на второго. Исследовательница уделяет большое внимание переписке Толстого и Лескова, их творческим и личным взаимоотношениям. А. А. Федотова высказывает предположение, что «рапсодия» «Юдоль» Лескова появилась, скорее всего, в результате отклика на призыв Толстого написать что-нибудь такое, что бы тронуло сердца. Исследователь анализирует структуру повести Лескова, образы героев, их монологи, речевые характеристики, показывает вкрапления в текст Лескова толстовских фраз и делает вывод о важном расхождении писателей, связанном со взглядами на простой русский народ и возможность его совершенствования.

Аналитическое изучение стилистической правки хроники «Захудалый род» Лескова представлено в статье Н. Ю. Даниловой, выделяющей основные направления авторедактирования в черновом автографе хроники, особенности творческой работы Лескова. Важные параллели видит автор между хроникой Лескова и отдельными памятниками древнерусской литературы.

Творческому наследию Лескова посвящена и статья А. А. Шелаевой о незавершенной исторической повести «Оскорбленная Нетэта», о замысле автора и его реализации. Исследовательница тщательно сравнивает сохранившиеся фрагменты, подвергает глубокому осмыслению образы героев. 
Вышедший в свет коллективный труд является фундаментальным; он еще раз убедительно демонстрирует объем уже сделанной, ведущейся и еще предстоящей текстологической работы. Несмотря на кажущуюся изученность творческого наследия многих классиков, в текстологии остается немало вопросов, требующих разрешения. Некоторые обозначенные в издании проблемы решены на его же страницах, другие проблемы только обозначены и требуют дальнейшего рассмотрения. Все статьи коллективного труда авторитетны и обладают высоким научным уровнем, основаны на широкой доказательной базе и множестве архивных источников. Текстологические открытия, представленные в издании в хронологическом порядке согласно времени жизни и творчества писателей и поэтов, слагаются в единое органичное исследование, дополняющее творческую историю произведений русской классики.

\section{Список литературы}

Бадалян Д. А. Книга И. С. Аксакова «Биография Федора Ивановича Тютчева»: История создания и цензуры, реконструкция первоначального текста // От истории текста к истории литературы. Вып. 2. М.: ИМЛИ, 2019. С. 261-304.

Белоусова Е. В. Повесть Н. Н. Толстого «Пластун» и ее основная художественная идея - «четыре эпохи развития» главного героя // От истории текста к истории литературы. Вып. 2. М.: ИМЛИ, 2019. С. 376-424.

Eсипов B. М. Отдельные проблемы текстологии поэтического творчества А. С. Пушкина // От истории текста к истории литературы. Вып. 2. М.: ИМЛИ, 2019. C. 9-50.

Коровин В. И. О стихотворении М. Ю. Лермонтова «Выхожу один я на дорогу...» // От истории текста к истории литературы. Вып. 2. М.: ИМЛИ, 2019. C. $88-116$.

Николаева Е. В. Из творческой истории «Азбуки» Л. Н. Толстого (1871-1872) // От истории текста к истории литературы. Вып. 2. М.: ИМЛИ, 2019. С. 425-439.

Романова Н. И. Сцена возвращения Анны Карениной в Петербург: к истории текста романа // От истории текста к истории литературы. Вып. 2. М.: ИМЛИ, 2019. C. $440-458$.

Щербакова М. И. Служение гению // От истории текста к истории литературы. Вып. 2. М.: ИМЛИ, 2019. С. 503-531.

\section{References}

Badalian D. A. Kniga I. S. Aksakova "Biografiia Fedora Ivanovicha Tiutcheva": Istoriia sozdaniia i tsenzury, rekonstruktsiia pervonachal'nogo teksta [Book of I. S. Aksakov "Biography of Fedor Ivanovich Tyutchev": History of creation and censorship, 
reconstruction of the original text]. Ot istorii teksta $\mathrm{k}$ istorii literatury. Vyp. 2 [From the history of the text to the history of literature. Vol. 2]. Moscow: IMLI Publ, 2019. P. 261304. (In Russ)

Belousova E. V. Povest' N. N. Tolstogo "Plastun” i ee osnovnaia khudozhestvennaia ideia - "chetyre epokhi razvitiia" glavnogo geroia [The story of N. N. Tolstoy "Plastun" and its main artistic idea - "four epochs of development" of the protagonist]. Ot istorii teksta $\mathrm{k}$ istorii literatury. Vyp. 2. [From the history of the text to the history of literature. Vol. 2]. Moscow: IMLI Publ, 2019. P. 376-424. (In Russ)

Esipov V. M. Otdel'nye problemy tekstologii poeticheskogo tvorchestva A. S. Pushkina [Some problems of the textology of poetry A. S. Pushkin]. Ot istorii teksta $\mathrm{k}$ istorii literatury. Vyp. 2. [From the history of the text to the history of literature. Vol. 2]. Moscow: IMLI Publ, 2019. P. 9-50. (In Russ)

Korovin V. I. O stikhotvorenii M. Iu. Lermontova "Vykhozhu odin ia na dorogu..." [About the poem of M. Yu. Lermontov "I go out alone on the road ..."]. Ot istorii teksta $\mathrm{k}$ istorii literatury. Vyp. 2. [From the history of the text to the history of literature. Vol. 2]. Moscow: IMLI Publ, 2019. P. 88-116. (In Russ)

Nikolaeva E. V. Iz tvorcheskoi istorii "Azbuki" L. N. Tolstogo (1871-1872) [From the creative history of the Alphabet by L. N. Tolstoy (1871-1872)]. Ot istorii teksta k istorii literatury. Vyp. 2. [From the history of the text to the history of literature. Vol. 2]. Moscow: IMLI Publ, 2019. P. 425-439. (In Russ)

Romanova N. I. Stsena vozvrashcheniia Anny Kareninoi v Peterburg: $k$ istorii teksta romana [The scene of the return of Anna Karenina to St. Petersburg: to the history of the text of the novel]. Ot istorii teksta $\mathrm{k}$ istorii literatury. Vyp. 2. [From the history of the text to the history of literature. Vol. 2]. Moscow: IMLI Publ, 2019. P. 440-458. (In Russ)

Shcherbakova M. I. Sluzhenie geniiu [Serving a Genius]. Ot istorii teksta k istorii literatury. Vyp. 2. [From the history of the text to the history of literature. Vol. 2]. Moscow: IMLI Publ, 2019. P. 503-531. (In Russ) 


\section{СЕТЕВОЕ ИЗДАНИЕ}

Научный журнал

Два века русской классики / Two centuries of the Russian classics

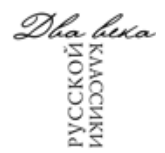

$$
2019 \text { - T. } 1 \text { - № } 2
$$

Учредитель и издатель Институт мировой литературы им. А. М. Горького

Российской академии наук

\section{Главный редактор}

Щербакова Марина Ивановна

доктор филологических наук, профессор, заведующая отделом русской классической литературы ИМЛИ РАН

\section{Дизайн обложки и макет журнала Компьютерная верстка}

Д. К. Бернштейн А. З. Бернштейн

\section{Корректор}

В. Г. Андреева

Журнал зарегистрирован

Федеральной службой по надзору в сфере связи, информационных технологий и массовых коммуникаций (Роскомнадзор) Свидетельство о регистрации: ПИ № Эл 77-76366 от 02.08.2019 г.

\section{Адрес учредителя, редакции и издателя:}

121069, Москва, ул. Поварская, 25а

Тел.: (495)690-50-30

E-mail: jornal_ork@mail.ru

Сайт журнала: www.rusklassika.ru

Дата размещения сетевого издания в сети Интернет на официальном сайте http://rusklassika.ru 10.12.2019 г.

При перепечатке ссылка обязательна 


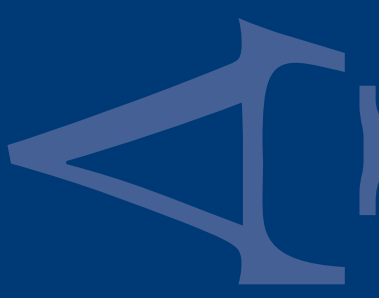

Arecincengen

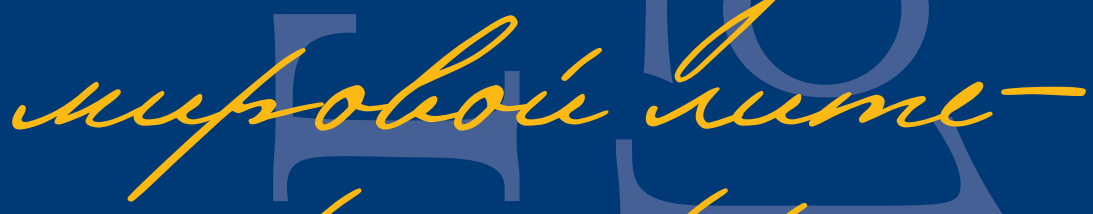



